\title{
НАУКОВИЙ ВІСНИК
}

МИКОЛАЇВСЬКОГО НАЦІОНАЛЬНОГО УНІВЕРСИТЕТУ імені В. О. СУХОМЛИНСЬКОГО

\section{ІСТОРИЧНІ НАУКИ}

Засновано 2008 p.

\section{№ 1 (47) \\ червень 2019}

Внесено до Переліку фахових видань України

галузі «Історичні науки»

(наказ МОН України від 12.05.2015 р. № 528)

Миколаїв

МнУ імені В. О. Сухомлинського 
Рекомендовано до друку рішенням наукової ради Миколаївського національного університету імені В. О. Сухомлинського

(протокол № 24 від 27.06.2019р.)

Валерій БУДАК

Надія РИЖЕВА

Владислав ПАРХОМЕНКО

ОЛЬГа БАКОВЕЦЬКА

Наталя БУГЛАЙ

Олександр ГУРЖІй

Віктор ДАНИЛЕНКО

Микола ЗЕРКАЛЬ

Ігор НІКОЛАЄВ

Володимир СЕРГІЙчУК

Євген СІНКЕВИЧ

Валерій ЕРМІЛОВ

Юрій котляР

\section{РЕ ДАКЦІ ЙН А КО Л ЕГІ Я:}

доктор технічних наук, професор, академік НАПН України; голова редакційної колегії;

доктор історичних наук, професор, головний редактор;

доктор історичних наук, доцент; відповідальний секретар.

\section{Ч Л ЕН И РЕДАКЦ І Й Н Ӧ̈ КО Л Е Г Ї:}

доктор історичних наук, доцент (Миколаївський національний університет імені В. О. Сухомлинського);

доктор історичних наук, доцент (Миколаӥвський національний університет імені В. О. Сухомлинського);

доктор історичних наук, професор (Інститут історії України НАН України, м. Київ);

член-кореспондент НАН України, доктор історичних наук, професор (Інститут історії України НАН України, м. Київ);

доктор історичних наук, доцент (Миколаївський національний університет імені В. О. Сухомлинського);

доктор історичних наук, доцент (Миколаївський національний університет імені В. О. Сухомлинського);

доктор історичних наук, професор (Київський національний університет імені Т. Шевченка);

доктор історичних наук, професор (Державна вища східноєвропейська школа, м. Пшемисль, Польща).

\section{Р Е Ц Е Н З Е Н Т И:}

доктор історичних наук, професор (Миколаївський обласний інститут післядипломної педагогічної освіти);

доктор історичних наук, професор (Чорноморський національний університет імені Петра Могили).

Науковий вісник Миколаївського національного універ-

Н 34 ситету імені В. О. Сухомлинського. Історичні науки : зб. наук. праць. - № 1 (47), червень 2019. - Миколаїв : МНУ імені В. О. Сухомлинського, 2019. - 116 с.

ISSN 2519-2809

Журнал зареєстровано в системі CrossRef.

DOI: 10.33310/2519-2809-2019-47-1

У збірнику наукових праць вміщено статті з актуальних проблем історичної науки, зокрема історіографії, краєзнавства, вітчизняної та всесвітньої історії. Значна кількість матеріалу присвячена малодослідженим питанням історії України.

Для наукових співробітників, викладачів вищих навчальних закладів, краєзнавців, аспірантів, студентів історичних спеціальностей.

УдК 930

ББК 63 


\section{M I C T}

\section{Розділ 1 \\ ІСТОРІЯ УКРАЇНИ}

Олена МОРОЗАН Державна політика щодо студентської молоді у 20-30-ті роки XX століття: сутність та основні тенденції............................................................................................ 5

Микола ЗЕРКАЛЬ Пожежна охорона УСРР в роки непу: регіональний аспект ............................................. 11

Віра РЕВЕНКО Форми дозвілля та відпочинку сільських дітей в повоєнний період........................ 20

Жужанна ДолИНАЙ Співробітництво між Україною та радою Європи у питаннях національних меншин.

Валерій БОГУНЕНКО Етносоціальні та геодемографічні коди пам'яті монопрофільних міст Донбасу

\section{Розділ 2 \\ ВСЕСВІТНЯ ІСТОРІЯ}

Наталя БУГЛАЙ Зовнішня політика Республіки Польща в зарубіжній історіографії..

Єва КІШ

Європейські принципи та функції євро-регіонального та транскордонного співробітництва

Єва КІШ, Жофіа ДОРГАЙ

Перспективи майбутнього розвитку Європейського Союзу 52

Володимир КУЗОВКОВ

Візантійська дипломатія у творах Константина VII Багрянородного

Оттила ЙОВЖА Новизна в оцінці історичної постаті Д’єрдя Дожі до 500-річчя селянської війни

Ярослав ШКАБУРА К Крестю Раковський: анархіст-революціонер чи добропорядний громадянин (1891-1918 рр.)?

(за матеріалами архіва французької поліції).

Ласлов ЗУБАНИЧ Дворянство північно-східної Угорщини XVI-XVII ст.

соціально-економічний аспект розвитку

\section{Розділ 3}

ІСТОРІОГРАФІЯ ТА ДЖЕРЕЛОЗНАВСТВО

Елеонора КОВАЧ

Маріанна ЛАСІНСЬКА

Джерела з вивчення міжнародних та міжконтинентальних міграцій єврейського населення кінця XIX - початку XX століття..

Владислав ПАРХОМЕНКО

Історико-мемуарна спадщина Л. Чикаленка про події 1919 р. в Україні 95

\section{Розділ 4}

\section{ІСТОРИЧНЕ КРАЄЗНАВСТВО}

Віталій КУЧЕР

Розвиток сільського господарства Миколаївської області

наприкінці XX - на початку XXI ст.

Єва КІШ, Камілла МАРОШАН

Особливості функціонування культурних закладів Закарпаття

за період 1950-1953 років на основі матеріалів преси

Геннадий КОВАЛЬ Планирование строительства Николаевской городской управой канализации в 1909 и 1912 годах. 108

ВІДОМОСТІ ПРО АВТОРІВ 


\section{CONTENTS}

\section{Chapter 1 \\ HISTORY OF UKRAINE}

MOROZAN 0. State policy on student youth in 20th-30th years of XX century:

essence and major trends .

ZERKAL M.

Fire protection of the USSR in the years of nep (new economic policy):

regional aspects

REVENKO V. Forms of leisure and recreation of rural children in the postwar period...

DOLINAI Z.

Cooperation between Ukraine and Council of Europe on issues national minorities

BOGUNENKO V. Ethno-social and geodemographic memory codes in Donbas monoprophile cities.

\section{Chapter 2 \\ WORLD HISTORY}

BUGLAY N.

Foreign policy of Republic is Poland in foreign historiography . .40

KISH Yeva

European principles and functions of euro-regional and trans-frontier cooperation

DORGAY Z., KISH Yeva

The European Union future development perspectives . 52

KUZOVKOV V. Byzantine diplomacy in the works of Constantine VII Porphyrogenitus. .. .57

JÓZSA A.

Novelty in the evaluation of the historical figures of György Dozsa

to the 500th anniversary of the peasant uprising..

SHKABURA Y. Krestu Rakovsky: anarchist-revolutionary or a good citizen (1891-1918)?

(according to the materials of the french police archive)

ZUBANYCH L. The nobility of north-east Hungary in XVI-XVII century - the social-economic aspect of development

\section{Chapter 3 \\ HISTOROGRAPHY AND SOURCING}

KOVACH E.

Analysis of newspaper articles on the siege of Przemysl fortress.. . .83

LASINSKA M. The Sources for studying of international and intercontinental migrations of jewish population in late XIXth - early XXth century...

PARKHOMENKO V. Historical and memoir heritage of L. Chikalenko about events 1919 in Ukraine . .95

\section{Chapter 4 \\ HISTORICAL REGISTRATION}

KUCHER V.

Development of agriculture of Mykolaiv region at the end of the XX - beginning of the XXI century

KISH Yeva, MAROSHAN K.

Functioning peculiarities of cultural institutions in Zakarpattia during 1950-1953 based on newspaper articles.

KOVAL G.

Nikolaev city sewage system administration, planning and consruction in 1909 and 1912 


\title{
Розділ 1 \\ ІСТОРІЯ УКРАЇНИ
}

DOI: 10.33310/2519-2809-2019-47-1-5-10

УдК 930.1:94(477) "1920/1930"

\author{
ОЛЕНА МОРОЗАН \\ викладач кафедри історії \\ Миколаївського національного університету імені В. О. Сухомлинського \\ м. Миколаїв, Україна \\ e-mail: elena.bz@gmail.com
}

\section{ДЕРЖАВНА ПОЛІТИКА ЩОДО СТУДЕНТСЬКОЇ МОЛОДІ У 20-30-ті РОКИ ХХ СТОЛІТТЯ: СУТНІСТЬ ТА ОСНОВНІ ТЕНДЕНЦІЇ}

\begin{abstract}
Розвиток студентської молоді відбувається в умовах конкретного суспільства. Держава, здійснюючи політику щодо молоді, може більшою чи меншою мірою сприяти цьому процесові. У контексті вивчення організації навчання та громадського життя студентської молоді у часи становлення радянської влади актуальним видається розгляд основних аспектів політики держави щодо цієї специфічної категорії суспільства. Аналіз нормативних документів, якими визначалась ия політика, допоможе скласти цілісну картину досліджуваного прощесу.

Ключові слова: молодь, комсомол, пролетаризація, соціалістичне будівництво, комуністична партія, студентство.
\end{abstract}

Досить складним, суперечливим і малодослідженим явищем виступає державна політика щодо студентської молоді в радянські часи. Російські вчені О. В. Алешонок, В. А. Луков вважають, що в СРСР політика по відношенню до молоді проводилася для свого часу не без успіху [2, с. 78]. Вона знайшла своє закріплення в законодавстві, у системі державних органів та інших атрибутивних для політики виявах. Ця політика завжди була невід'ємною складовою частиною партійної політики щодо молоді. Здійснення їі відбувалося за такою схемою: основна їі частина проводилася через Всесоюзну Ленінську комуністичну спілку молоді (далі - ВЛКСМ) (фактично єдина молодіжна організація), інша - через державні органи освіти, охорони здоров'я, оборони, внутрішніх справ, держкомспорту, інформаційні відомства, культурно-освітні заклади. Що стосується студентства, то насамперед через органи освіти. Об'єктом цієї політики була студентська молодь, яку нама- гались виховати в дусі «будівника комунізму». Вона не розглядалась як суб'єкт цього процесу. Молодіжна політика мала патерналістський характер і вимагала від молодого покоління діяти і розвиватися в заданому напрямку.

На місцях вона проводилася через місцеві партійні і комсомольські комітети, державні органи влади, громадські організації. Координація конкретної роботи з молоддю була прерогативою комсомолу, що проводив ії під керівництвом і за сприяння партії. Характерною рисою цієї політики на місцях була ії уніфікованість як за напрямками роботи, так і за формами провадження.

Основна відмінність політики держави щодо молоді загалом і студентства зокрема від політики у ставленні до жінок, дітей, інвалідів та інших незахищених верств населення полягає у тому, що вона не зводиться лише до компенсаторських механізмів (допомоги, підтримки тощо), а передбачає активну інноваційну 
участь молоді у житті суспільства, спираючись на трудовий і творчий потенціал молодого покоління. Це зумовлює розгляд питань цієї політики в ряду питань стратегічного розвитку, нарощування творчого потенціалу, інноваційних ресурсів суспільства. Студенти як представники молодого покоління являють собою органічний суб'єкт розвитку економічного, політичного, соціального. Це дуже добре розуміли представники радянської системи. У часи Радянського Союзу було зроблено все для того, щоб виховати молодь у комуністичному дусі, готувати покоління справжніх комуністів. Саме $з$ цією метою у центр політики держави щодо молоді була поставлена ВЛКСМ, складовою частиною якої була ЛКСМУ. Контролювала ця організація і діяльність студентства. Комсомол для здійснення своєї роботи мав достатнє фінансування, представництво в органах державної влади, всебічну підтримку комуністичної партії і найвищих керівників держави.

Майже $з$ першого дня створення комсомольської та піонерської організацій, партійні та державні органи республіки заявили про їхню безмежну підтримку лише двох цих організацій. У рішеннях V конференції КП(б)У у листопаді 1920 року записано: “Діяльність Комуністичної Спілки Молоді України має величезне значення для всієї роботи КПУ. 3 огляду на важливість юнацького руху для всього партійного і радянського будівництва партія повинна, з одного боку, належним чином налагодити тісний зв'язок із спілкою, необхідний контроль і зміцнити свій вплив у iї рядах, а з іншого - надавати їй всіляку підтримку і матеріальну допомогу" [6, с. 67].

Існують постанови і рішення з'їздів, пленумів і конференцій ЦК ВКП(б), у яких відображено також основні напрями політики щодо молоді, до якої ми відносимо і студентів. Звичайно, що вони були обов'язковими для виконання усіма союзними республіками. Найбільшу цікавість для нас являють ті матеріали, які тією чи іншою мірою стосувалися такої унікальної молодіжної групи як студенти. У радянській період більшість 3 них були комсомольцями, тож слід зупинитися на аналізі відповідних документів. На тринадцятому з'їзді ВКП(б) у Москві 23-31 трав- ня 1924 року була прийнята постанова “Про роботу серед молоді”, у якій окремо виділявся пункт "Вища школа і молодь": мова в ньому йшла про необхідність раціонального комуністичного виховання молоді у вищих навчальних закладах $[1$, с. 281]. Вважаючи за потрібне поліпшити загальну учбову ситуацію у закладах освіти, партія має приділяти особливу увагу роботі у сільськогосподарських та педагогічних вузах. Цим підкреслювалась значущість спеціальностей відповідного (сільськогосподарського і педагогічного) спрямування для суспільства в умовах будівництва нової держави. Підтверджувала це і теза про те, що в разі скорочення вузів необхідна строга відповідність цього скорочення 3 неоднаковим значенням навчальних закладів різних спеціальностей [1, с. 282]. У цьому документі також виділявся аспект, притаманний усій системі тодішнього виховання молоді: і навчання, і практика, окрім цілей, пов'язаних з оволодінням студентами системою знань, вмінь і навичок, повинні забезпечувати політичне виховання молоді. У цьому процесі керуючу роль повинні відігравати партійні та комсомольські ячейки закладів освіти. Таким чином, закладалася одна 3 головних засад політики держави щодо студентської молоді - необхідність ії політичного та ідейного виховання. У 1930 році, 13 вересня, була прийнята постанова ЦК ВКП(б) “Про задачі партосвіти”, у якій окреслювалися основні шляхи посилення ролі партії у житті суспільства: велика роль у цьому надавалась молоді як активному учаснику усіх перетворень. Пропонувалося посилити значущість партійного чинника в освіті, розширити мережу комуністичних вузів. Це необхідно було для виховання ідейно підготовлених членів суспільства, які б виконували усі доручення держави. Тенденції, висвітлені у цій постановi, продовжувалися і в наступні роки. Так, у постанові ЦК ВКП(б) “Про заходи по допомозі комсомолу” (7 вересня 1932 року) були визначені конкретні завдання партійної роботи, спрямовані на поліпшення діяльності комсомолу, зокрема, на надання практичної допомоги з боку відділів ЦК партії відділам ЦК ВЛКСМ [7, с. 20]. Комуністам рекомендувалося широко інформувати комсомольські 
кадри по найважливіших питаннях політики партії та діяльності Ленінського комсомолу, планувалося проведення перевірки виконання місцевими організаціями партії директив ЦК про закріплення партійців-комсомольців на роботі у Комуністичній Спілці Молоді. Відповідно центральні організації комсомолу мали передавати усю інформацію своїм місцевим осередкам, а ті, в свою чергу, інформувати усіх членів. Ця постанова стала програмою діяльності партійних організацій по керівництву комсомолом. Нею були намічені найбільш доцільні для даного періоду методи роботи. Велику роль у справі зміцнення ролі партії у житті молоді та контролі за діяльністю Комуністичної Спілки Молоді відіграли рішення XII з'їзду ВКП(б) (січень - лютий 1934 року). 3'їзд зобов'язав партійні організації поліпшити керівництво комсомолом, вказати на конкретні форми і методи їх роботи з молоддю, рекомендував перейти від "загального" керівництва до конкретного, від прийняття "загальних" резолюцій до вжиття оперативних заходів, що грунтуються на вивченні дійсного стану справ, до тісного і живого зв'язку з низовими ланками комсомолу, посилення особистої відповідальності керівників за доручену їм справу, систематичної перевірки виконання директив партії та уряду. Основним завданням ВЛКСМ визначалося - зробити Ленінський комсомол школою різнобічної державної діяльності [6, с. 315].

Виконуючи рішення з'їзду ЦК ВКП(б), Центральні комітети компартій союзних республік, у тому числі ЦК КП(б)У, послідовно втілювали курс на вдосконалення "партійного керівництва” комсомолом. Однією з провідних форм цього керівництва, якій Комуністична партія надавала великого значення, було зміцнення партійного ядра в лавах ВЛСКМ. Поширеною формою у практичному керівництві комсомолом був інститут партприкріплених. Вони брали активну участь у житті комсомольських організацій, одночасно контролюючи їх роботу. 3 середини $30-\mathrm{x}$ рр. практика виділення партприкріплених для діяльності в комсомолі стала значно звужуватися. Натомість дедалі більшу роль в системі партійного керівництва ВЛКСМ починає відігравати здійснення принципу функціональ- ного впливу на діяльність комсомольських ланок з боку членів партійного бюро або комітету.

У квітні 1936 року в продовження виконання постанов ЦК ВКП (б) у Москві відбувся Х з'їзд ВЛКСМ. Він підтримав курс на перебудову комсомольської роботи, вдосконалення ïi форм та методів, підпорядкування їі завданням виховання і навчання молоді. У зв'язку з цим підкреслювалося, що “комуністичне виховання молоді повинно проводитися так, щоб кожний крок ії̈ навчання був зв'язаний 3 боротьбою за створення комуністичного суспільства" [9, с. 54]. Перед комсомолом було висунуто завдання посилити боротьбу під керівництвом партії за завершення побудови соціалізму, підкресливши, що без активної участі радянської молоді у соціалістичному будівництві неможливо здійснювати їі комуністичне виховання. На з'їзді було прийнято новий текст Статуту ВЛКСМ, який відобразив зміни, що відбулися в житті і діяльності Спілки молоді. Він закріпив той факт, що комсомол 3 переважно робітничо-селянської за складом організації став організацією усієї молоді Союзу РСР. Позитивним було і встановлення однакового для усіх категорій молоді порядку прийому в комсомол незалежно від соціального стану, скасувавши певні обмеження, які були введені в 1921 році для учнівської і службової молоді.

Відомо, що саме в 1930-ті рр., в умовах перебудови радянського суспільства була здійснена так звана "культурна революція": значно розширилася мережа навчальних закладів, збільшилося число учнів, студентів, молодих наукових працівників, представників інших груп радянської інтелігенції. Усе це сприяло розширенню бази зростання комсомольських рядів за рахунок цієї категорії молоді. Так, у вузах України за період з 1931 по 1937 р. кількість членів ВЛКСМ зросла у 2,5 рази $[9$, с. 57]. Таким чином, можна відмітити очевидну тенденцію: в умовах, коли відбувалася реорганізація народного господарства, зміна у суспільстві - і все це йшло швидкими темпами, вище керівництво відчуло потребу у тих, хто зможе якісно сприяти усім цим процесам - це мали бути насамперед високоосвічені люди. Якщо брати серед молоді, 
то, в першу чергу, це стосується студентів. Тож партії залишалося лише належним чином ідейно підготувати їх, і це мав забезпечити комсомол.

Окрім постанов і рішень загального характеру, які стосувалися молоді загалом, були і такі, що торкалися безпосередньо студентства. 23 червня 1936 року прийнято Постанову ЦК ВКП(б) та РНК СРСР “Про роботу вищих навчальних закладів та про керівництво вищою школою”. Причиною для її появи стала соціалістична реконструкція народного господарства, яка висунула високі вимоги до молодих фахівців. У ній приділено велику увагу організації навчально-виховного процесу у вищих навчальних закладах, матеріальному забезпеченню студентів, прийому та умовам вступу. Головна ідея, яка проходить крізь цю Постанову - будь-яким чином забезпечити підготовку у вищих навчальних закладах висококваліфікованих спеціалістів, 3 якісними знаннями, з гарною теоретичною, але, головне, практичною підготовкою, ладних виконувати усі завдання, поставлені державою [6, с. 358]. Багато в чому цей документ мав раціональне зерно, адже він пропагував необхідність порядку і дисципліни під час навчання, відповідальність керівництва за усі процеси, що відбуваються під його контролем; рівність під час вступу тощо. Але, на жаль, у ньому ще раз підтверджувалася тенденція щодо вузів, закладена ще у 20-ті pp. централізація у керівництві і відсутність самостійності.

Студентство брало активну участь у молодіжному русі, який у своєрідній формі розвивався і у досліджуваний період. Ще у перші роки існування радянської України почала формуватися специфічна підсистема цього руху - регулятивна, як складова частина тієї політики, що проводила держава. Вона була спрямована, з одного боку, на створення єдиної, підпорядкованої правлячому режимові, організації молоді, діяльність якої, з іншого боку, не повинна була регламентуватися законодавчими актами, а мала повністю визначатися статутом партії.

Разом з тим, були приклади того, що ще в середині 20-х років у радянській Україні всетаки робилися спроби юридичного узаконен- ня молодіжного (і як складової частини - студентського) та дитячого руху. Так, коли створювалися перші українсько-радянські кодекси, громадськістю було порушено питання про видання єдиного нормативного акту так званого “Дитячого кодексу”, який би закріплював правовий статус молоді.

За ініціативи Всеукраїнської комісії у справах неповнолітніх відповідні пропозиції почали обговорюватися в Україні. У 1926 році ідею створення Кодексу УСРР про права та пільги молоді підтримав ЦК ЛКСМУ, а уряд республіки навіть спланував приблизну дату проекту на своєму засіданні. Було опрацьовано декілька варіантів, проте робота над проектом призупинилася, оскільки Наркомат юстиції УСРР висловився проти підготовки такого акту, вважаючи, що кодекс не матиме самостійного значення, а зведеться до дублювання норм трудового, кримінального i адміністративного законодавства. Врештірешт точка зору юристів перемогла і справа не дійшла до створення проекту.

Однією з основних тенденцій, що визначали сутність політики держави щодо студентської молоді у перші десятиліття становлення радянської влади, було прагнення уряду впливати на соціальний склад студентства вищих навчальних закладів. Виявлялося це у спрощенні умов вступу до вузів та наданні переваг робітничо-селянській молоді. 3 одного боку, такий курс може бути пояснений складними соціально-економічними умовами, у яких опинилася країна внаслідок подій 1917-1920 років і необхідністю підготувати багато спеціалістів, здатних відновити економіку країни, а з іншого - це була складова політики радянського уряду, спрямованої на обмеження прав представників інших верств населення.

Так, щоб полегшити вступ робітничій та селянській молоді до вищої школи, на певний час було скасовано обов'язкове подання при вступі атестатів зрілості. Вступники повинні були мати тільки достатні знання. Так, у Києві, Харкові, Катеринославі та Одесі тощо Народний комісаріат освіти УРСР створив курси для підготовки до вступу у вузи робітників.

Внаслідок таких дій держави швидко змінювався соціальний склад студентів інститутів і техникумів (у 30-ті роки університетів). 
Так, якщо у 1928 році робітники в інженернотехнічних становили близько 60\%, то в 1932 році - понад 70\% студентів, а в деяких інститутах - навіть близько 100\%. Цей процес мав своїм наслідком і негативну тенденцію: доволі часто викладачами відмічався доволі низький рівень знань абітурієнтів, що ускладнювало процес підготовки висококваліфікованих фахівців.

Для 20-30-х років було характерним виховання з представників молодого покоління партійних та радянських працівників, для чого в Україні створювалася мережа партійної освіти - радпартшкіл і комвузів. На кінець 1925 року в УРСР діяла 41 радпартшкола з 5 тис. слухачами. Через цю мережу було підготовлено десятки тисяч партійних, радянських та комсомольських працівників та пропагандистів.

Партійні організації велику увагу приділяли збільшенню партійного та комсомольського прошарків серед студентів. На навчання до вузів щороку посилалися комуністи й комсомольці з державної чи партійної роботи, а особливо - 3 виробництва, місцеві партійні організації проводили кропітку роботу для “укріплення" окремих вузів. I це мало певні результати: значно зросла кількість комуністів і комсомольців у таких закладах. Так, якщо у 1929 році вони становили лише 29,6\% загальної кількості студентів, то в 1938 році -
41,1\%. Це означало посилення ролі партійних та комсомольських організацій у навчальновиховній роботі та в усьому житті вузів.

Ще однією характерною рисою державної політики було приділення уваги підготовці національних кадрів (особливо у період українізації). На початок 1938 року українці становили $54,2 \%$ загальної кількості студентів вузів України.

Відсутність реального самоуправління у молодіжному середовищі, авторитаризм старших над молодшими, надумані “почини" та “ініціативи”, які нічого не давали ані молоді, ані суспільству - це все те, що визначає сутність політики держави щодо молоді загалом, i студентства, зокрема. У складному, неоднозначному процесі соціалізації молодого покоління рівень вимог, що висувалися суспільством до нього, не відповідав умовам для їх реалізації молоддю, іï місцю і ролі в суспільстві. Прагнення молоді різних категорій (учнівської, службової і студентської в тому числі) проявити себе у тих чи інших формах, які відповідають їі інтересам і рівню розвитку, скрізь наштовхувалися на нерозуміння, байдужість або глуху стіну неприйняття з боку представників старшого покоління, держави, партії. У цьому відношенні не були позитивними явищами політизація і пролетаризація, які охопили усі процеси, що відбувалися у суспільстві, в тому числі, i, наприклад, освіту і життя студентства.

\section{Список використаних джерел}

1. Ленин В. И. Задачи союзов молодежи (речь на III Всероссийском съезде Российского коммунистического Союза молодежи 20 октября 1920 г.) // Полн. собр. соч. М.: Политиздат, 1969. Т. 41. С. 278-318.

2. Луков В. А. Молодежное движение в социалистическом обществе. Вопросы теории и практики. М.: Молодая гвардия, 1987. $239 \mathrm{c}$.

3. Вища педагогічна освіта і наука України: Історія, сьогодення та перспективи розвитку. Миколаївська область / За заг. редакцією В.Д. Будака. К.: Знання України, 2010. 311 с.

4. Головатий М. Ф. Молодіжна політика в Україні: проблеми оновлення. К.: Наукова думка, 1993. 238 с.

5. Історія Української РСР. У двох томах. Т. 2. К.: Наукова думка, 1967.860 с.

6. КПСС о комсомоле и молодежи. Сборник резолюций, решений съездов, конференций партии, постановлений цК КПСС и других партийных документов. 1917 - 1961. М., 1962.528 с.

7. КПСС в резолюциях и решениях съездов, конференций, пленумов ЦК (1898 - 1986). Т. 4. 1925 - 1928. М.: Политиздат, 1984. С. $72-94$

8. Кукушкин Ю. С., Чистяков О. И. Очерк истории Советской Конституции. М.: Политиздат, 1987. 367 с.

9. Лях В. І., Шевченко В. О. Партійне керівництво організаційним зміцненням ЛКСМУ (1933 - 1937 рр.) Український історичний журнал. 1987. № 2. С. 53-58.

\section{References}

1. Lenyn V. Y. Zadachy soiuzov molodezhy (rech na III Vserossyiskom sъezde Rossyiskoho kommunystycheskoho Soiuza molodezhy 20 oktiabria 1920 h.) // Poln. sobr. soch. M.: Polytyzdat, 1969. T.41. S. 278 - 318.

2. Lukov V. A. Molodezhnoe dvyzhenye v sotsyalystycheskom obshchestve. Voprost teoryy y praktyky. M.: Molodaia hvardyia, 1987. $239 \mathrm{~s}$.

3. Vyshcha pedahohichna osvita i nauka Ukrainy: Istoriia, sohodennia ta perspektyvy rozvytku. Mykolaivska oblast. / Za zah. redaktsiieiu V.D. Budaka. K., Znannia Ukrainy, 2010. 311 s.

4. Holovatyi M.F. Molodizhna polityka v Ukraini: problemy onovlennia. K.: Naukova dumka, 1993. 238 s. 
5. Istoriia Ukrainskoi RSR. U dvokh tomakh. T. 2. K.: Naukova dumka, 1967. - $860 \mathrm{~s}$.

6. KPSS o komsomole y molodezhy. Sbornyk rezoliutsyi, reshenyi sъezdov, konferentsyi partyy, postanovlenyi TsK KPSS y druhykh partyinыkh dokumentov. 1917 - 1961. M., 1962. $528 \mathrm{~s}$.

7. KPSS v rezoliutsyiakh y reshenyiakh sъezdov, konferentsyi, plenumov TsK (1898 - 1986). T. 4. 1925 - 1928. M.: Polytyzdat, 1984. S. 72-94.

8. Kukushkyn Yu. S., Chystiakov O. Y. Ocherk ystoryy Sovetskoi Konstytutsyy. M.: Polytyzdat, 1987. 367 s.

9. Liakh V. I., Shevchenko V. O. Partiine kerivnytstvo orhanizatsiinym zmitsnenniam LKSMU (1933 - 1937 rr.) Ukrainskyi istorychnyi zhurnal. 1987. № 2. S. 53-58.

\section{Морозан 0. Государственная политика по отношению к студенческой молодежи в 20-30-тые годы XX века: сущность и основные тенденции}

Развитие студенческой молодежи происходит в условиях конкретного общества. Государство, осуществляя политику относительно молодежи, может в большей или меньшей степени способствовать этому процессу. В контексте изучения организации учебы и общественной жизни студенческой молодежи в период становлення советской власти актуальным кажется рассмотрение основных аспектов политики государства относительно этой специфической категории общества. Анализ нормативних документов, которыми определялась эта политика, поможет составить целостную картину изучаемой проблемы.

Ключевые слова: молодежь, комсомол, пролетаризация, социалистическое строительство, коммунистическая партия, студенчество.

\section{Morozan 0. State policy on student youth in 20th-30th years of XX century: essence and major trends}

Development of student young people takes place on a background and in the coat of general tendencies of civilization advancement, development of certain society as a transition of young man from one quality state to other, that is answered by the changes of her legal status, socio-economic position, methods of bringing in to the social structure, to character of vital functions and others like that. The state, carrying out policy in relation to youth, may to a greater or lesser extent to facilitate this process. In the context of studying learning and social life of student's youth in the days of the Soviet regime, it is important to review the main aspects of state policy in relation to this specific category of companies. The analysis of regulations, which determined this policy will help to create a holistic picture of the studied process.

Prospects for the development of society are fairly associated with youth, in particular with students. But objectively, the energy, strength and potency of the younger generation can play a positive role in the development of society only under certain conditions. The most important among them is the attitude of older generations, public institutions and especially the state, which is manifested in its politics. If, as a result of the implementation of such a policy, the necessary conditions are created, sufficient guarantees for the social formation and development of the young people being trained, they will be able and willing to direct their capacities in accordance with the interests of society in all spheres of their life. The absence of concrete actions or inadequate policy conduct leads to serious crisis phenomena in the youth environment, in particular, in the whole society as a whole. From this, the attitude of the state institutions to the younger generation and their influence on the training of specialists is very important.

No less actual within the framework of research of the outlined problem is a period that is examined. 20 - 30th XX age is a period which, no doubt, it is possible to describe as a decade of changes. It is a very difficult and in a great deal critical moment of Ukrainian history. Instability of political and economic situation, decline of culture, growth of illiteracy, among a population, absence of aspiration and possibility to the self-education - it only short list of consequences of events 1917 - 1920 years. In these conditions, it became necessary to train highly qualified specialists, which, by their work, would contribute to the restoration of all spheres of society's life. The study of the main trends and regularities inherent in the process of preparing students in educational institutions in the first decades of the formation of Soviet power, will bring us closer to understanding the transformations that have taken place in the system of education and society later and still occur. And as you know, the creation of the present and the prediction of the future is impossible without a careful analysis of the past. This is especially important in connection with the desire to bring the Ukrainian educational system closer to European standards, with changes in traditional approaches to the educational process in higher education institutions.

Key words: youth, Komsomol organization, proletarization, socialist construction, communist party, student. 
DOI: 10.33310/2519-2809-2019-47-1-11-19

УДК 908 «1921/1925»

\author{
МИКОЛА ЗЕРКАЛЬ \\ доктор історичних наук, професор кафедри історії \\ Миколаївського національного університету імені В. О. Сухомлинського, \\ м. Миколаїв, Україна \\ e-mail:nikolaizerkal@gmail.com
}

\title{
ПОЖЕЖНА ОХОРОНА УСРР В РОКИ НЕПУ: РЕГІОНАЛЬНИЙ АСПЕКТ
}

\begin{abstract}
Автором в статті розкривається практика діяльності органів пожежної безпеки в роки НЕПу на прикладі Миколаївщини. Проаналізовано існуючий науковий доробок украӥнських дослідників історії пожежної безпеки України. Комплексного дослідження з обраної теми, на жаль не існує, сьогодні здійснюються лише окремі спроби регіонального висвітлення такої важливої теми, як організація пожежної безпеки на території України в ХХ ст. Збереження матеріальних цінностей окремих громадян, промислових підприємств, державної власності традиційно були актуальними $і$ зберігають по сьогоднішній день надзвичайну важливість.

Автор піднімає питання організаційних форм та методів забезпечення в умовах ринкової економіки 1920-х років створення ефективно працюючої системи протипожежної безпеки. Пожежники - герої повсякденності і слід знову і знову пригортати увагу читачів до їх роботи, життя, проблем і можливих варіантів покращення існуючої технічної та організаційної структури органів пожежної безпеки в Україні. В статті досліджуються факти перевірки життям створених протипожежних структур та матеріальних засобів в 1920-х роках в Миколаєві.

Ключові слова: пожежа, повінь, спасіння, рятівник, допомога, збереження, вдячність грома$\partial я н$.
\end{abstract}

Постановка проблеми. В сучасних умовах випробувань незалежності України, складній світовій економічній кон'юнктурі, набуває особливого значення використання внутрішніх економічних чинників для наповнення державного бюджету, в умовах втілення політики децентралізації - місцевих бюджетів податковими відрахуваннями представників малого та середнього бізнесу. Автор намагається своїм дослідженням звернути увагу на законодавче регулювання та практику діяльності структур пожежної охорони Півдня України в роки втілення політики НЕПу, коли збереження вирощеного врожаю, виготовленої продукції набувало особливого значення, адже голод, економічна руїна, політична ізоляція, здійснення різноманітних економічних, адміністративних та державницьких реформ не могли здійснити ефективного захисту матеріальних цінностей.

Проведення адміністративної реформи децентралізації в сучасній Україні викликало низку складних економічних та організаційних питань щодо забезпечення пожежної безпеки підприємницьких структур та окремих громадян зокрема. Дослідник вважає помилковим ставлення до органів пожежної безпеки як до елементу ринкової економіки, що має сам піклуватись про матеріальне забезпечення, соціальний захист своїх працівників, підготовку кваліфікованих кадрів та формувати відповідне ставлення у населення про свою роль в житті суспільства. Досліджуючи історичний досвід втілення НЕПу, як виключно практики тоталітарного комуністичного режиму, яку неможливо і недоцільно вивчати та використовувати в сучасних економічних і політичних умовах стосовно пожежної безпеки, сучасні історики свідомо обмежують формування цілісної картини об'єктивного державно-ринкового перетворення країни, зокрема в галузі пожежної безпеки. Саме тому обрана тема має актуальний характер та повинна пригорнути увагу інших дослідників до історії органів пожежної безпеки та інших маловивчених сторінок історії України початку XX ст.

Аналіз досліджень. Українська національна історіографія НЕПу пройшла у своєму розвитку три основних етапи. Перший із них 
охоплює 1920-ті - першу половину 1950-х рр. Другий - другу половину 1950-х - початок 1990-х рр. Сучасний етап історіографії розпочався після проголошення незалежності України й розпаду СРСР. На жаль комплексних досліджень історії створення та діяльності протипожежних органів на Півдні України не існує. Лише в останні роки ми стали свідками повільного пробудження інтересу істориків до вивчення регіональних аспектів діяльності органів пожежної безпеки. На жаль, більшість таких робіт обумовлено трагедіями останніх років із пожежами на військових складах, ЧАЕС, в торговельно-розважальних центрах та на гуртових ринках.

Радянська історична наука була цілком підпорядкована партійній доктрині. Це визначало й обумовлювало предмет і проблематику економічної історії. Подібно до того, як у процесі розвитку соціалістичної економіки головна увага приділялася виробничій сфері, промисловості й сільському господарству, а соціальна сфера, пожежна безпека конкретної людини та ії майна недооцінювалися, ігнорувалася їхня взаємозумовленість, й в історичній науці зазначені тенденції у повній міpi знайшли своє відображення. Прагнення вивчати історію непу з погляду політичної доцільності виокремило в радянській історіографії 1920-х - початку 1930-х рр. так звані актуальні, «потрібні» теми та проблеми (зокрема, широко висвітлювалася діяльність партійних функціонерів, нові форми використання трудового ентузіазму населення, діяльність споживчої кооперації тощо) й водночас коло таких питань, які вважалися не актуальними, табуйованими, про них було прийнято згадувати, лише критикуючи буржуазні концепції, наукові позиції зарубіжних вченихрадянологів.

Останнім часом 3'явились дослідження 3 історії органів пожежної безпеки окремих регіонів, зокрема Одеси [6; 7], Харкова [1; 18], Луганська [16], Києва [13], Запоріжжя [8], Миколаєва $[10 ; 11 ; 12]$ та ін. Спроби створити цілісне загальнодержавне історичне дослідження були здійснені окремими науковцями в останні два десятиліття [4; 18; 19]. Перший внесок в історіографічний процес зробили самі творці радянської системи - партійні та радянські керівники, економісти, які брали безпосередню участь у процесах соціалістичної модернізації. Історія протипожежної служби Миколаївщини також висвітлювалась в узагальнюючих роботах сучасних дослідників В. А. Пархоменка [12] та В. Ковальова [5].

На сьогоднішній день основні джерела 3 історії органів протипожежної безпеки 20-х років XX ст. можна знайти лише в архівах та періодичних виданнях.

Мета статті. Потреба сьогодні, в умовах зовнішньої агресії, складної економічної ситуації, згуртувати населення для захисту своєї незалежності та економічної самостійності набула надзвичайної важливості. Таким чином, метою даної розвідки є дослідження історичного досвіду формування та діяльності органів протипожежної безпеки також в кризовий історичний період української історії, забезпечення пожежної безпеки не лише майна підприємств, приватних компаній, громадян, а також і держави в цілому, зокрема на складах озброєння, військової техніки, яка знаходиться не лише на території військових частин, а також і під час ремонту, транспортування теренами нашої країни. Враховуючи наявність на території країни низки стратегічних вибухонебезпечних об'єктів, як електростанції, металургійні комбінати, нафто- та газопроводи, дослідження форм та методів роботи пожежників 1920-х років має стати гідним для вивчення сучасними рятувальниками досвіду, і уникнення помилок та прорахунків, заради збереження життя громадян та матеріальних цінностей країни.

Виклад основного матеріалу. Початок запровадження нової економічної політики на теренах нашої країни офіційно почалося 3 9 серпня 1921 р., коли В. Ленін підписав «Наказ Ради Народних Комісарів про впровадження в життя начал нової економічної політики [2]. За думкою Леніна, базою соціалізму мала стати велика машинна індустрія [3]. Відмовою від зовнішніх зобов'язань царату, СРСР поставив себе перед проблемою виходу з економічної кризи без допомоги іноземних кредиторів. 3 іншого боку, більшовики позбулися обтяжливих відсоткових виплат за боргами імперії Романових у 800-900 млн руб. золотом щорічно. 
Нова економічна політика мала створити умови для відновлення й розвитку великої промисловості, припинення міграції населення, залучення до державних органів та їх структурних підрозділів, в тому числі і вогнеборців, активної молоді. В своєму виступі нарком внутрішніх справ Г. І. Петровський звертаючись до пожежників влітку 1918 р. зазначав: «Надзвичайні політичні події сьогодення можуть викликати низку бід у вигляді значних пожеж, як це вже було 26 травня 1918 р. в Москві, в Тулі, що може повторитись в інших містах та селищах. Виходом з цього положення лише один - охорона народної власності від пожежних бід... Ця охорона вимагає надзвичайного напруження сил» $[17$, с. 72$]$. В Москві було навмисно підпалено вантажну станцію Казанської залізниці, де на коліях накопичилось багато ешелонів 3 хлібом, військовим озброєнням, пальним, реманентом. Вибухали цистерни з гасом та бензином, вогонь доходив до вагонів зі снарядами. Більше шести годин вогнеборці боролись з пожежею голіруч, відштовхували на безпечну відстань вагони і перемогли пожежу. Нові пожежні випробування на нафтосховищах в Сімоновській слободі, на військових складах на Ходинському полі впевнили радянську владу в потребі взяти під державний контроль протипожежну безпеку та органи пожежогасіння $[17$, c. 73$]$. Причому пожежники приймали активну участь не лише в надзвичайних ситуаціях, вони також приймали участь у військових діях і в Південній Україні.

В січні 1921 р. було створено пожежний відділ у складі Головного управління комунального господарства НКВС УСРР в Харкові [19, с. 17]. Саме пожежний відділ передавав накази та настанови з питань пожежної безпеки на місця до своїх структурних підрозділів: губернських підвідділів або секцій при губернських, міських, повітових відділах комунального господарства. Відповідно з чинним на той час законодавством, пожежний відділ Головного управління комунального господарства (головкомгосп) України здійснював загальне керівництво роботою всіх пожежних організацій спрямовуючи, контролюючи, проводячи інструктажі всіх підлеглих органів, а також за допомогою нижчих струк- турних підрозділів доводив до населення всі обов'язкові державні постанови 3 пожежної охорони, здійснював контроль за виконанням директив вищих державних виконавчих органів. Слід зазначити, що Всеукраїнський відділ складався з адміністративного, пожежно-технічного, відділу обліку, розподілу та постачання. Структура була невеликою, але ефективно побудованою і продемонструвала свою ефективність в майбутньому. На місцях справами займались губернські пожежні підвідділи (губпожпідвідділи) при губернських відділах комунального господарства (губвідкомгоспах). Самі завідувачі пожежних підвідділів отримували звання начальників пожежної охорони губернії. Призначення відбувалось із спеціалістів протипожежної боротьби після узгодження 3 Центральним відділом пожежної охорони УСРР. Губернські пожпідвідділи знаходились у підпорядкуванні пожвідділу ГУКГ УСРР та діяли відповідно із загальними положеннями та інструкціями, які видавались останнім.

За своїм статусом губернські пожежні підвідділи здійснювали керівництво роботою всіх пожежних організацій губернії, діяльність яких направляли, інструктували та контролювали. За допомогою місцевих владних органів видавали постанови місцевого значення, складали загальний план заходів з попередження та боротьби з пожежами з метою збереження всього майна незалежно від форми власності в губернії. На губпожпідвідділи покладався обов'язок здійснювати облік всіх без виключення предметів пожежного устаткування та спорядження селищ, містечок, міст, окремих відомств, господарчих об'єднань, окремих організацій та установ. Вони здійснювали спостереження за правильним дотриманням, використанням та доглядом у відношенні до цих предметів, а також визначали необхідність наявності в районах потрібного пожреманенту.

3 січня 1920 р. м. Миколаїв остаточно перейшов до рук більшовиків. Починається новий етап в житті та діяльності вогнеборців. Незважаючи на адміністративні перетворення коли Херсонська губернія була поділена на Одеську та Херсонську з центром в Миколаєві, а з грудня 1920 р. отримала назву 
Миколаївської. В 1922 р. відбувається реорганізація губерній і Одеська та Миколаївська об'єднуються в Одеську. 3 березня 1923 р. виокремлюється в їі складі Миколаївський округ. В таких умовах адміністративних перетворень питання пожежної безпеки залишалось вкрай актуальним.

3 квітня 1920 р. в Миколаєві створюється Губпожежвідділ для організації та відновлення протипожежної роботи. В грудні 1920 р. поже- жний відділ переходе у підпорядкування новоствореного Губкомунвідділу. Фактично в цей період в селах Миколаївщини внаслідок мобілізацій до різних військових формувань було повністю припинено діяльність підрозділів пожежогасіння. Завдяки наполегливій роботі на кінець 1920 р. в Миколаївському повіті нараховувалось 65 добровільних дружин. В умовах голоду 1921-1922 рр. незважаючи на скрутне матеріальне забезпечення пожежників,
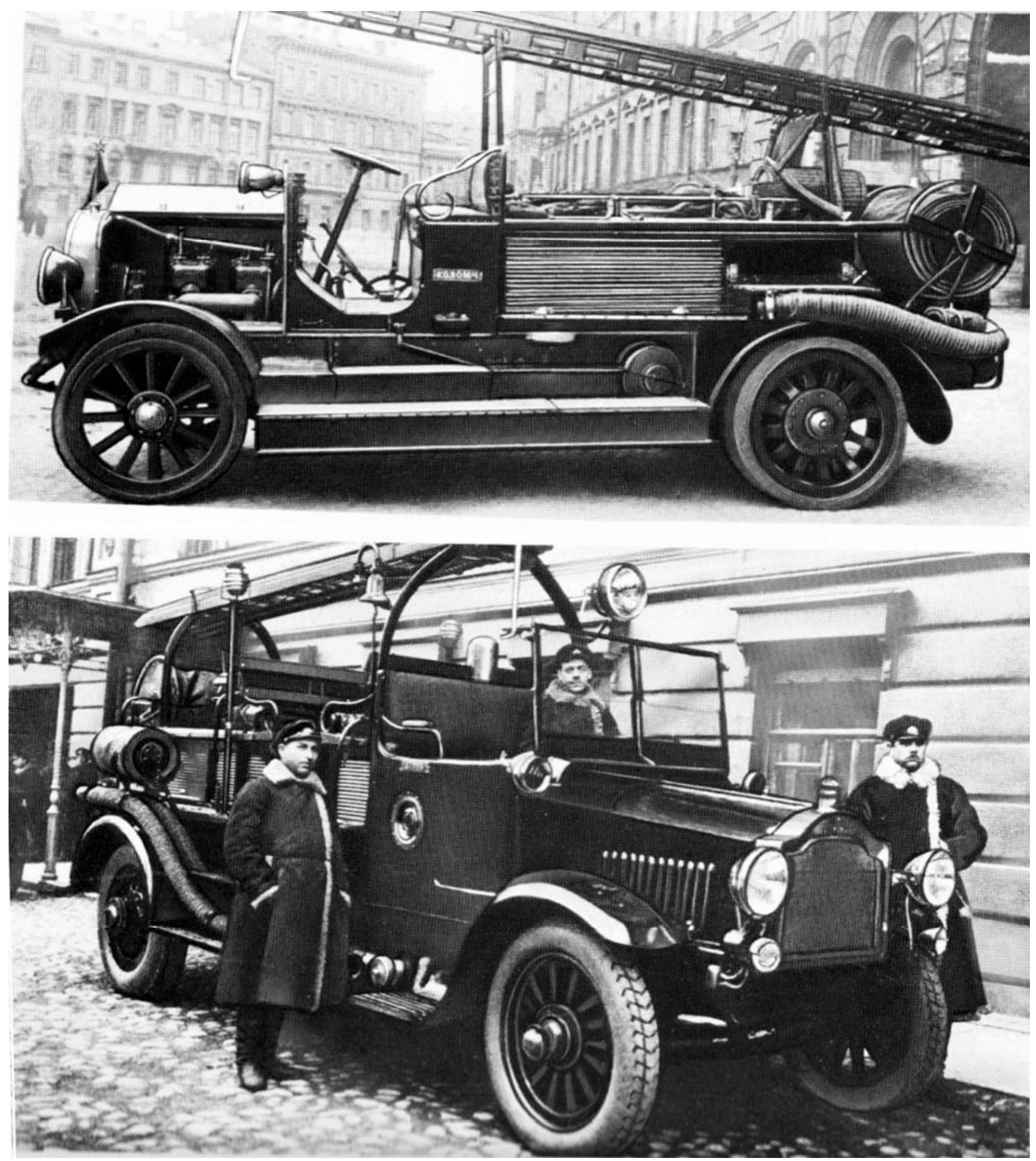

Пожежна техніка I пол. 1920-х pp. 
було організовано цілодобове чергування на продовольчих складах «АРА» (Американська адміністрація допомоги) [12, с. 50].

В Миколаєві завдяки очільнику М. Свіжинському було запроваджено тризмінне чергування, що значно покращило привабливість служби в пожежних частинах. Було також прийнято на місцевому рівні рішення, що при виникненні та ліквідації значних пожеж почали залучатись пожежні команди підприємств, розроблено та втілено відповідний план взаємодії. 3 серпня 1921 р. М. Свіжинський призначається начальником всієї протипожежної служби м. Миколаєва. Цікава статистика матеріального забезпечення пожежників Миколаївщини в 1922 р., так в Бо- гоявленську де налічувалось 2 тис. подвірь, 13 тис. мешканців були в наявності: 1 насос, 2 бочки, 2 багра; в Широкій Балці де було 225 подвірь, 1015 мешканців: 1 бочка, 2 багра; на Водопої де налічувалось 755 подвірь, 3840 мешканців: 1 бочка; в Мішково-Погоріловому (508 подвірь, 2697 мешканців): 1 насос і 1 бочка. Кількісно команди пожежників також були малочиисельні: Вознесенськ 12 пожежників із 8 конями і 3 бочками; Очаків: 16 пожежників із 6 кіньми. В Миколаєві були в наявності 4 спеціалізовані автомобілі, облаштовано 400 гідрантів від магістралі міського водогону, 14 коней, а також працювало 97 чоловік [12, с. 51]. В процесі відновлення діяльності промислових підприємств було
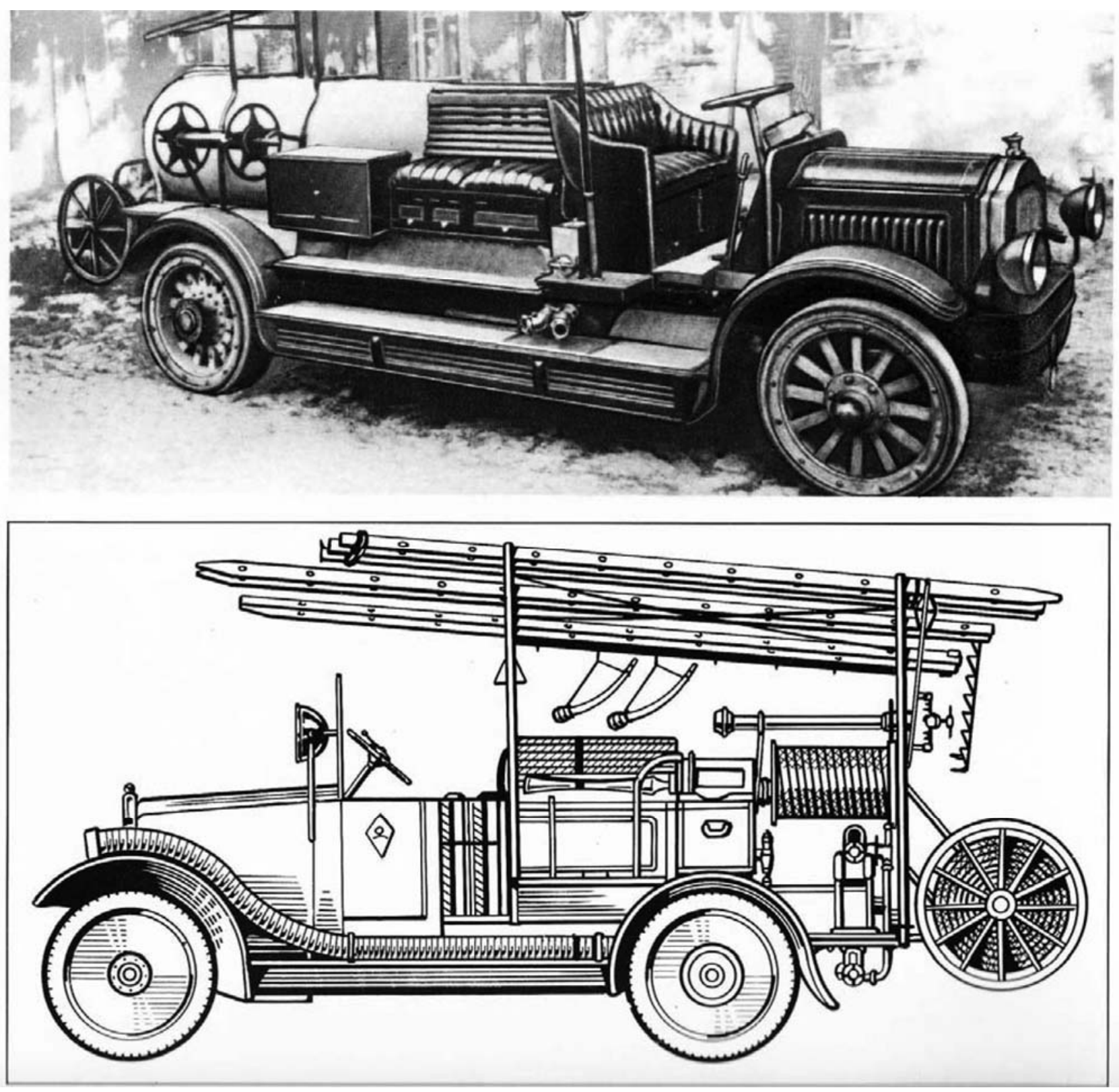

Пожежна техніка I пол. 1920-х pp. 
створено 6 добровільних пожежних дружин із складу їх працівників. Найкращим було матеріальне забезпечення у команди торговельного порту, яка успадкувала з дореволюційного періоду два парових насоси.

Свої навички та професійні якості пожежники проявили під час ліквідації пожежі в квітні 1923 р. на миколаївському елеваторі. В місцевій пресі було висвітлено трагічні події 18 квітня 1923 р., починаючи з 4 години ранку, коли почалась поширюватись пожежа 3 1 корпусу елеватора. Внаслідок розслідування експерти дійшли висновку про навмисний підпал, адже пожежа почалась через 10 годин після відключення електрики. 3400 тис. пудів зерна було врятовано 300 тис. пудів. В пожежогасінні було задіяно також 200 робітників підприємства. За висновком спеціальної комісії Раднаркому УСРР причиною визнавались дії «контрреволюційних осіб» [12, с. 53].

Внаслідок масштабної пожежі було вжито необхідних заходів на інших підприємствах, наприклад для портової команди було обла- штовано автомобіль, збудовано мотопомпу та відремонтовано пожежний катер «Тамань». В 1928 р. в Ленінграді (Санкт-Петербург) було придбано для порту новий пожежний катер «Струя».

На місці пожежі побував голова РНУ УСРР $\mathrm{X}$. Раковський і за рішенням Першої Всеукраїнської пожежної конференції (1923р.) Миколаївська команда була занесена на Червону дошку пошани Головного управління комунального господарства НКВД УСРР [10, с. 19].

В процесі згортання політики НЕПу пожежники залучались не лише до пожежогасіння, а також і до ліквідації природних та техногенних лих. Наприклад, в травні 1925 р. внаслідок відсутності облаштованої системи стічної каналізації значна частина міста була затоплена повенню. В ніч з 11 на 12 травня внаслідок зливи було затоплено низку вулиць, зупинено роботу електричної та телефонної станцій. Пожежники організовано виносили на руках старих та дітей із затоплених будинків. Було задіяно мотопомпу

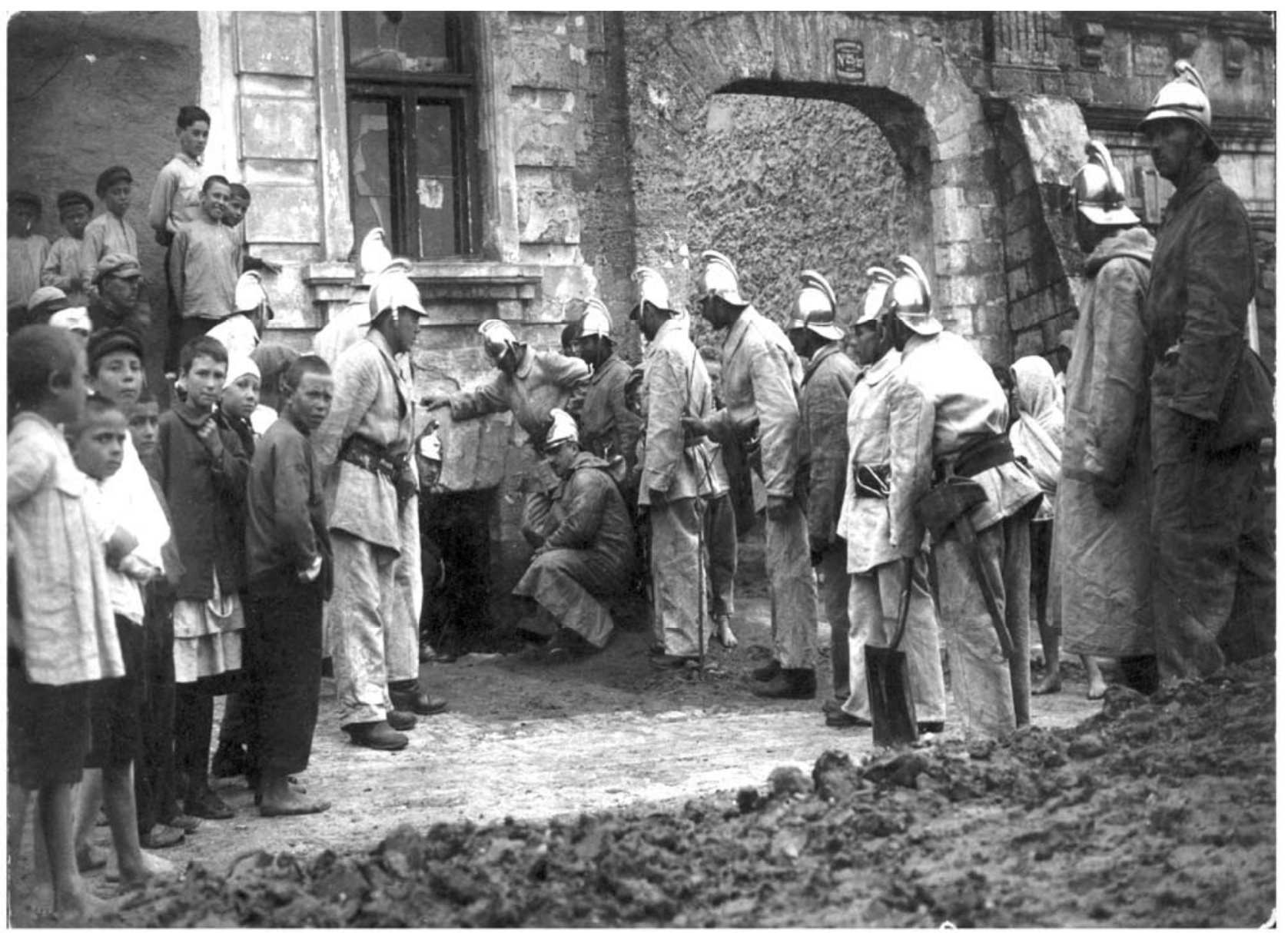

Пожежники під час ліквідації наслідків повені в Миколаєві. Фото 1925 р.

(з фондів Миколаївського обласного краєзнавчого музею) 
Морпорту, яка викачувала 5 тис. відер води на годину. Як зазначали офіційні джерела загиблих не було, і в цьому визначну роль відіграли саме пожежні підрозділи [12, с. 56].

Фактично до періоду згортання НЕПу пожежна команда Миколаєва мала на озброєнні 5 машин. Незважаючи на те, що це був період певної економічної стабілізації все одно матеріальне забезпечення пожежників залишалось проблемою. Наприклад, брандмайстер отримував 46 крб., враховуючи надбавки $25 \%$ за світякові та вихідні дні, сокирники 22 крб. 12 коп., що не могло повністю забезпечити потреби людини без пошуку додаткового заробітку [12, с. 65].

Висновки. Досліджуючи період значних змін в економічній політиці більшовиків, запровадження елементів ринкової економіки, ми змогли простежити значну увагу партійного та державного керівництва до питань пожежної безпеки. Усвідомлення важливості попередження та ліквідації пожеж не лише з точки зору забезпечення збереження матеріальних цінностей окремих громадян і їх життя, а також убезпечення значних матеріальних і економічних ресурсів країни в цілому. Забезпечення економічної незалежності країни лягло на плечі створених пожежних відділів та місцевих підрозділів, які створили всі умови для швидкого та ефективного реагування на ви- клики стихії. Утримання їх в державних структурах свідчило про стратегічне бачення подальшої ролі протипожежних структур у справі розробки протипожежних вимог, використання розгалуженої та ефективно підготовленої організації для усунення наслідків надзвичайних природничих, техногенних або інших загроз. Сьогодні слід врахувати досвід 1920-х років, який зазначив вагому роль конкретних особистостей які самовідданою роботою в даній справі не лише відновили організаційні структури, а також змогли знайти важелі для залучення молодих енергійних фахово підготовлених робітників, винайти можливість для створення потрібної матеріальної бази із врахуванням специфіки міста, кількості населення, географічного розташування, промислової спрямованості виробництва та наявних терміналів в портах. Питання матеріального забезпечення та ставлення суспільства до виконуваних працівниками функцій відгравало і продовжує відігравати вирішальну роль для ефективності їх діяльності в критичний момент. Історичний досвід продемонстрував, що кількість залучених до ліквідації лиха людей, повинно бути також забезпечено матеріальними ресурсами, як автомобілями, так і іншими технічними пристроями, що забезпечують швидке пожежогасіння, збереження матеріальних цінностей і людського життя.

\section{Список використаних джерел}

1. Глебова И. Н. Испытание огнем: Очерк истории Харьковской пожарной охраны. Харьков, 1991. 127 с.

2. Зеркаль М. М. Нова економічна політика на Півдні України в 20-ті роки XX ст. // Історія Півдня України від найдавніших часів до сучасності: проблеми національного, політичного, технічного, правового, релігійного та культурного розвитку: Зб. наук. праць. Миколаїв, Одеса, 1999. Ч. II. 260 с.

3. Зеркаль М. М. Економічні перетворення в промисловості Півдня України на початку 1920-х рр. Наукові праці: Науково-методичний журнал. Т.100. Вип.87. Історичні науки. Миколаїв; Вид-во ЧДУ ім. Петра Могили, 2009. С. 60-66.

4. Козинець 0. В. Діяльність добровільних пожежних формувань у Наддніпрянській Україні в другій половині XIX - на початку XX ст. : дис. ... канд. іст. наук: 07.00.01. Черкаси, 2010.

5. Ковальов В. М. Добровільне пожежне товариство Миколаївщини : Історичний нарис. Миколаїв, 1999. 194 с.

6. Литвяков Ф. И. Одесса в отблесках пожаров. Одесса, 2013. 384 с.

7. Литвяков Ф. І., Антипов Ю. Ф. 200 лет на линии огня: [Историко-краеведческий очерк]. Одеса: Астропринт, 2002. $120 \mathrm{c}$.

8. Нехаев В. С. Огнеборцы Запорожья: Очерки истории и деятельности пожарной охраны Запорожской области. Запорожье, 1997. $124 \mathrm{c}$.

9. Островский Б., Марченко Л. Огнеборцы. Киев, 1996. 162 с.

10. Пархоменко В., Єрмаков М. Підприємливий начальник. Пожежна безпека. 2005. № 3. С. 18-19.

11. Пархоменко В. А. Николаевский брандмейстер Ф. И. Пономарев // ІХ Миколаївська обласна краєзнавча конференція. Миколаїв, 2015. С. 134-136.

12. Пархоменко В. А. Очерки истории противопожарной службы г. Николаева (1848 - 1928 гг.). Николаев: издатель Торубара В. В., 2015. 112 c.

13. Попович С. С., Миць О. В. У вогненній борні (з історії пожежництва Жовківщини). Львів, 2003. 150 с.

14. Попович С. Пожежна охорона Львівщини (1772-1939). Львів, 1999.78 с.

15. Полтанов О. І. та ін. Історія пожежної охорони Кіровоградщини (1841-1997). Дніпропетровськ, 1998. 256 с.

16. Смирнов Г. В. Историческая хроника пожарной охраны Луганска. Луганск, 1996. 416 с.

17. Советская пожарная охрана / Сост. Ворошилова Т. А. Москва: Внешторгиздат, [Б.г.] 350 с. 
18. Томіленко А. Г. Пожежна справа на Правобережній Україні в другій половині XIX - початку XX ст. : дис... канд. іст. наук: 07.00.01. Черкаси, 2000.

19. Харламов М. І. Становлення та розвиток системи пожежної безпеки в УСРР у 1918-1934 рр. Харків: ФОП Панов А.М., 2019. 388 c.

20. Чекін М. Б. Одвічний поклик вогнеборців: Літопис пожежної охорони Подільського краю. Вінниця, 2002. 192 с.

\section{References}

1. Glebova I. N. Ispytanie ognem Ocherk istorii Kharkovskoi pozharnoi okhrany [Trial by Fire: An Essay on the History of the Kharkovsky Fire Department]. Kharkov, 1991. 127 s. [in Russian].

2. Zerkal M. M. Nova ekonomichna polityka na Pivdni Ukrainy v 20-ti roky XX st. [New economic policy in the South of Ukraine in the 20 years of the twentieth century]. // Istoriia Pivdnia Ukrainy vid naidavnishykh chasiv do suchasnosti: problemy natsionalnoho, politychnoho, tekhnichnoho, pravovoho, relihiinoho ta kulturnoho rozvytku: Zb. nauk. prats. Mykolaiv; Odesa, 1999. Ch. II.-260 s. [in Ukrainian].

3. Zerkal M. M. Ekonomichni peretvorennia v promyslovosti Pivdnia Ukrainy na pochatku 1920-kh rr.[ Economic transformations in the industry of the South of Ukraine in the early 1920's.] Naukovi pratsi: Naukovo-metodychnyi zhurnal. T.100. Vyp.87. Istorychni nauky. Mykolaiv; Vyd-vo ChDU im .Petra Mohyly, 2009. S. 60-66. [in Ukrainian].

4. Kozynets 0. V. Diialnist dobrovilnykh pozhezhnykh formuvan u Naddniprianskii Ukraini v druhii polovyni XIX - na pochatku XX st. [ The activities of voluntary fire brigades in the Dnieper Ukraine in the second half of the 19th and early 20th centuries] : dys. ... kand. ist. nauk: 07.00.01. Cherkasy, 2010 [in Ukrainian].

5. Kovalov V. M. Dobrovilne pozhezhne tovarystvo[Volunteer Fire Society of Mykolaiv Region: Historical Essay] Mykolaivshchyny: Istorychnyi narys. Mykolaiv, 1999.-194 s. [in Ukrainian].

6. Litviakov F. I. Odessa v otbleskakh pozharov [Odessa in the glow of fires].Odessa 2013. $384 \mathrm{~s}$. [in Russian].

7. Litviakov F. Antipov U. 200 let na linii ognia [200 years in the firing line:][Istoriko-kraevedcheskii ocherk]. Odesa: Astroprint, 2002. 120 s. [in Russian].

8. Nekhaev V. S. Ognebortsy Zaporozhia. Ocherki istorii i deiatelnosti pozharnoi okhrany Zaporozhskoi oblasti[Firefighters of Zaporozhye: Essays on the history and activities of the fire department of Zaporizhzhya region] Zaporozhe 1997.124 s. [in Russian].

9. Ostrovskii B., Marchenko L. Ognebortsy[Firemen]. K., 1996.162 s. [in Russian].

10. Parkhomenko V., Yermakov M. Pidpryiemlyvyi nachalnyk [Entrepreneur] Pozhezhna bezpeka. 2005. № 3. S. 18-19. [in Ukrainian].

11. Parkhomenko V. A. Nikolaevskii brandmeister F. I. Ponomarev [Nikolayev firefighter F. I. Ponomarev] Mikolaivska oblasna kraeznavcha konferents v Mikolaev. 2015. S 134-136. [in Russian].

12. Parkhomenko V. A. Ocherki istorii protivopozharnoi sluzhby g. Nikolaeva 18481928 gg. [Essays on the history of the fire service of Nikolayev (1848 - 1928)]. Nikolaev: izdatel Torubara V. V., 2015112 s. [in Russian].

13. Popovych S. S., Myts O. V. U vohnennii borni (z istorii pozhezhnytstva Zhovkivshchyny) [ In the fiery boron (from the history of fire in Zhovkva)]. Lviv, 2003. 150 s. [in Ukrainian].

14. Popovych S. Pozhezhna okhorona Lvivshchyny (1772-1939) [Fire protection of Lviv region (1772-1939)]. Lviv, 1999.78 s. [in Ukrainian].

15. Poltanov 0. I. ta in. Istoriia pozhezhnoi okhorony Kirovohradshchyny (1841-1997)[ History of the fire protection of Kirovograd region (1841-1997)]. Dnipropetrovsk, 1998. 256 s. [in Ukrainian].

16. Smirnov G. V. Istoricheskaia khronika pozharnoi okhrany Luganska[Historical chronicle of the fire of Lugansk] Lugansk 1996. 416 s. [in Russian].

17. Tomilenko A. H. Pozhezhna sprava na Pravoberezhnii Ukraini v druhii polovyni XIX - pochatku XX st. : dys... kand. ist. nauk: 07.00.01. Cherkasy, 2000.

18. Sovetskaia pozharnaia okhrana [Soviet fire brigade]. Sost Voroshilova T. A. Vneshtorgizdat Moskva. 350 s. [in Russian].

19. Kharlamov M. I. Stanovlennia ta rozvytok systemy pozhezhnoi bezpeky v USRR u 1918-1934rr. [Formation and development of the fire safety system in the USSR in 1918-1934.]. Kharkiv: FOP Panov A.M., 2019. 388 s. [in Ukrainian].

20. Chekin M. B. Odvichnyi poklyk vohnebortsiv: Litopys pozhezhnoi okhorony Podilskoho kraiu [An age-old call of fire brigade: Chronicle of fire protection of the Podilsky Krai]. Vinnytsia, 2002. 192 s. [in Ukrainian].

\section{Зеркаль Н. Пожарная охрана УССР в годы нэпа: региональный аспект}

Автором в статье раскрывается практика деятельности органов пожарной безопасности в годы НЭПа на примере Николаевской области. Проанализирована историография исследования данной темы украинских учёных. Комплексного исследования по теме, к сожалению пока нет, на данный момент существуют лишь отдельные попытки регионального освещения такой важной темы, как организация пожарной безопасности на территории Украины в ХХ ст. Сохранение материальных ценностей отдельных граждан, промышленных предприятий, государственной собственности традиционно были актуальными и сохраняют по сей день чрезвычайную важность. Автор поднимает проблемы организационных форм и методов обеспечения противопожарной безопасности в условиях рыночной экономики 1920-х годов, создание эффективно работающей системы противопожарной безопасности. Пожарные - герои повседневности и следует снова и снова привлекать внимание читателей к их работе, жизни, проблемам и возможным вариантам улучшения существующей технической и организационной структуры органов пожарнои безопасности в Украине.В статье исследуются факты проверки жизнью созданных противопожарных структур и материальных средств в 1920-х годах в Николаеве.

Ключевые слова: пожар, наводнение, спасение, спасатель, помощь, сохранение, благодарность граждан. 


\section{pects \\ Zerkal M. Fire protection of the USSR in the years of nep (new economic policy): regional as-}

In today's conditions of political testing of the independence of modern Ukraine, in conditions of external aggression, the complex world economic situation becomes of particular importance to use internal economic (actors for filling the state budget, in the context of the implementation of decentralization policy local budgets tax deductions of small and medium businesses). By studying the historical experience of the realization of the NEP as exclusively the practices of the totalitarian communist political regime, which is impossible and inappropriate to study and use in today's economic and political conditions regarding fire safety, modern historians deliberately restrict the formation of a coherent picture of the objective statemarket transformation of the country, particulary in the field of fire safety. That is why the chosen topic is relevant and should draw the attention of other researchers to the history of fire safety authorities and other poorly-studied pages of the history of Ukraine at the beginning of the XXth century.

By studying the period of significant changes in the economic policies of the Bolsheviks, the introduction of elements of a market economy, we were able to track the considerable attention of the consignment and state leadership to the issues of fire safety. Awareness of the importance of preventing and eliminating fires not only from the point of view of ensuring the preservation of the material values of individual citizens and their lives, as well as the safeguarding of the material and economic resources of the country as a whole. Ensuring the economic independence of the country fell on the shoulders of established fire departments and local units that created all the conditions for a rapid and effective response to the challenges of the elements. Detention in state structures showed a strategic vision of the future role of fire brigade in the development of fire requirements, control over compliance with accepted requirements in the field of fire safety and the use of an extensive and effectively trained organization to eliminate the effects of extraordinary natural sciences, tech gene or other threats. Today it is necessary to take into account the experience of the 20-ies, which noted the important role of specific individuals who selfless work in this case not only restored organizational structures, but also able to find leverage to attract young energetic, well-trained workers, to invent the opportunity to create the necessary material base, taking into account the specifics cities, population, geographic location, industrial direction of production and available terminals in ports. The question of material support and the attitudute of society to the functions performed by employees has played out and continues to play a decisive role for the effectiveness of their activities at a critical time. Historical experience has shown that the number of people involved in the elimination of disasters must also be provided with material resources, both by automobiles and other technical devices that provide rapid fire fighting, the preservation of material values and human life.

Key words: fire, flood, salvation, savior, help, preservation, gratitude of citizens, verification. 
DOI: 10.33310/2519-2809-2019-47-1-20-23

УдК 94(477)

\author{
BIPA PEBEHKO \\ кандидат історичних наук, \\ старший викладач кафедри історії \\ Миколаївського національного університету імені В. О. Сухомлинського, \\ м. Миколаїв, Україна \\ e-mail: verarevenko84@gmail.com
}

\title{
ФОРМИ ДОЗВІЛЛЯ ТА ВІДПОЧИНКУ СІЛЬСЬКИХ ДІТЕЙ В ПОВОЄННИЙ ПЕРІОД
}

\begin{abstract}
У статті проаналізовано форми і види відпочинку дітей у повоєнний період. Подано характеристику та опис офіційних і неофіційних форм дозвілля. 3'ясовоно, що організований відпочинок школярів знаходився під особливим контролем радянської влади, яка уміло використовувала його у власних цілях, отримуючи дієві важелі впливу на формування їх світогляду. Основна увага приділялася патріотизму, відданості партії та любові до Батьківщини, трудовому та фізичному вихованню.

Ключові слова: дозвілля, відпочинок, діти, учнівська молодь, школяри, ідейне виховання, радянська партійна державна система.
\end{abstract}

Невід'ємним елементом життя дитини $є$ дозвілля, яке впливає на формування світогляду та особистості. У повоєнний період вільний час дитини був чітко спланованим, спрямованими на фізичний розвиток, формування здорового способу життя, виховання у дусі радянської ідеології. Офіційне дозвілля школярів планувалося і контролювалося державою, а індивідуальне залежало від інтересів та можливостей кожної дитини.

Дозвілля та відпочинок дітей включає різноманітні форми та види проведення вільного часу, в досліджуваний період його можно умовно поділити на дві окремі групи:

Офіційне (державне): 1) гурткова робота в школі, організація вечорів, екскурсій, відвідування театрів, кінотеатрів, організація дозвілля позашкільними навчальними закладами, організований відпочинок дітей під час канікул та ін.;

2) неофіційне (самоорганізоване): сюди входять елементи дитячої субкультури, ігри дітей на вулиці, читання різнопланової літератури, журналів, газет, прослуховування радіо, ігри на дитячих майданчиках, прогулянки [1, с. 158].

У зазначений період дозвіллю та відпочинку школярів приділялося достатньо уваги, проводилися шкільні, районі, всеукраїнсь- кі та всесоюзні виховні заходи, з єдиною метою - контроль та формування світогляду дітей в дусі радянського патріотизму.

Організація дозвілля дітей та учнівської молоді покладалася на вихователів, вчителів, на піонерські та комсомольські організації, які у позаурочний час проводили екскурсії, різноманітну гурткову роботу, вечори відпочинку, конференції, тематичні зустрічі та лекції, походи тощо. Окрім школи існували позашкільні установи, які опікувалися вихованням дітей, зокрема клуби, бібліотеки та ін.

Одним із ефективних способів здійснення інтенсивного виховного впливу стало створення дитячих оздоровчих таборів, покликаних формування здорового способу життя, виховання у дусі радянської ідеології [2, с. 4-5]. Так, на Херсонщині створено 16 дитячих таборів, які охопили 5800 школярів [4, арк. 20]. Школярі працювали у таборах праці і відпочинку тільки в літній час i, як правило, на сільськогосподарських роботах. Суспільно корисної робота повина була виховати в школярів любов і повагу до праці та сформувати ї громадську активність.

Невід'ємною частиною дозвілля учнівської молоді були туристсько-краєзнавча робота. Масового характеру, у вільний від навчання час, набули екскурсії [4, арк. 5]. Для учнів 
Одеської області організовано 20 екскурсій [3, арк. 24]. Масштаби екскурсійної роботи зростали з кожним роком, і щорічно охоплювали все більшу кількість дітей. Незважаючи на заідеологізованість цієї форми роботи, вона була одна з найулюбленішею серед учнів i без сумніву, допомогла багатьом визначитися у майбутньому з вибором професії.

Під час культурного дозвілля дітей влітку значну роль відігравало кіно.Так, у 1950 р. на Херсонщині за час літніх канікул було продемонстровано дітям 1543 кіносеансів [4, арк. 18].

За період літніх канікул у школах, в піонерських таборах організовувалися і проводились різні змагання з акробатики, художньої гімнастики, плавання, волейболу, шашкам, шахам із загальною кількістю 28035 дітей [3, арк. 24].

Слід наголосити, що позашкільні установи відігравали важливу роль в організації дозвілля учнів, здійснюючи ідейно-політичне, моральне виховання під час гурткової, лекційної, масової роботи. Зокрема, у клубах здійснювали перегляд кінофільмів, фізкультурні змагання, виступи колективів самодіяльності учнів, ігри, організовувалися зустрічі з ветеранами війни та героями сучасності [4, арк. 4], [3, арк. 28]. Проте, в досліджуванний період не в усіх селах існували спеціальні позашкільні заклади, де б діти розвивали свої таланти, не завжди існували і гуртки, які вони могли відвідувати в вільний час.

Окремо слід зауважити, що сільські діти часто були позбавлені можливості вільно розпоряджатися своїм вільним часом, більшість після уроків виконували роботу по дому, старші діти піклувалися про молодших братів та сестер, а під час канікул їх залучали до роби в колгоспах.

В усіх дитячих закладах проводилися ранки, вечори присвяченні видатним датам, зустрічі з бійцями, командирами червоної армії та учасниками війни. Випускалися стінгазети, виписували періодичну літературу, користувалися бібліотеками - передвижками [5, арк. 34]. Крім «червоних» днів календаря у дитячих установах відзначали день народження Сталіна, день Конституції, День Перемоги, день авіації та ін.

Значна увага приділялася творчим іграм, які відображали дійсність. Проте, дитячі сад- ки часто відчували велику нестачу у відповідних засобах та літературі [5, арк. 40]. Взагалі у середині 40 - х років проблема іграшок стала особливо гостро. Було навіть прийняте спеціальне рішення партії: «Тепер, крім дитячого одягу, згідно з вказівками КП(б)У, швейники (ім. Кірова) розпочинають виготовлення іграшок для дітей» $[6$, с. 4]. Це рішення стосувалося не тільки швейників, а і всіх артілей, що відроджувалися після війни [7, с. 3]. До випуску дитячого асортименту долучалися і суднобудівні заводи Миколаєва. У багатьох їх цехах налагоджували випуск продукції для дітей: «Колектив судомонтажного цеху заводу ім. Марті виготовив для дітей загиблих воїнів та інвалідів Вітчизняної війни 100 комплектів різних іграшок» [8, с. 4].

На початку 50-х років у Миколаєві створено методичний центр по виробництву іграшок для дітей, при миколаївському обласному відділі освіти працювала художньотехнічна комісія. Нею затверджено п'ять зразків іграшок: дзига оригінальної конструкції, млин, вантажна машина, набір для піску та самоскид. Роботу по виготовленню цих іграшок доручено Миколаївській промартілі «15 років Жовтня» [9, с. 4].

У 50-ті роки іграшки робили з дерева, були м'які іграшки, целулоїдні, металеві, пластмасові, з пап'є-маше, скляні (ялинкові ), гумові, порцелянові, глиняні [10, с. 314]. До середини 1950-х років іграшки виготовлялись в артілях Миколаєва, Херсона, Одеси. Якість дитячих забав була дуже низькою. Наприклад, дитяча коляска, отримана на Одеській базі союзопткультуторга, мала непривабливий вигляд, з нестійким барвником, що обсипався. Піраміда дерев'яна, отримана на тій же базі, виготовлена Київським Горпромкомбінатом, невизначеного кольору, клейка зроблено недбало, неправильної форми. Ляльки в національних костюмах мали одяг похмурих тонів [11, арк. 113]. Не могла пишатися своєю продукцією артіль «Галкульт» м. Миколаєва. Ï̈̈ дитячі іграшки не міцні, невдалої обробки. Іноді, хоч бери і пиши оголошення: «Це ведмідь, а не верблюд» $[12$, с. 4]. У той же час іграшки виконували і політичну функцію - підкріплювали міф про найкраще в світі соціалістичне суспільство, чим був зумовлений іграшковий асортимент. Так, у радянські часи 
(кінець 1930-х - 1950-і роки) головними м'якими іграшками країни були ведмежа та собачка. Таке обмеження мало ідеологічну підоснову. Ведмідь вважався героєм російських народних казок, а собака - другом людини, кролик же і котеня символізували міщанство, кролик в протестантських країнах був завжди героєм пасхальних листівок. Слід сказати, що між ведмедем з російського фольклору і матерчатим ведмедиком-іграшкою загального дуже мало. Радянські ведмедики - іграшки невеликого розміру. Небезпідставно вважалося, що велика іграшка незручна в умовах життя цілої сім'ї в одній кімнаті $[13$, с. 101102]. Однак плюшеві іграшки могли дозволити собі не всі, через високі ціни вони не користувалися особливим попитом, наприклад, у 1951 р. «Ведмежа» коштувало 90 крб., «Ослик» - 35 крб., «Кіт у чоботях» - 35 крб. [11, арк. 113].

Велику популярність мали целулоїдні іграшки, вони мали великий попит і швидко реалізовувались. Справжнім дітищем радянської целулоїдної лялькової індустрії став «пупс». Роль цих абрикосово - рожевих створінь 3 рухливими ручками і ніжками на гумках, намальованим волоссям і 3 круглими блакитними очима виявилася дуже важливою для радянських дітей. Причин на те було багато: і відсутність вибору, і бідність, і необхідність застосувати на ділі навики шиття, щоб одягнути голяка (у ті роки уроки рукоділля для дівчаток були обов'язковою частиною учбової програми в школах). Він був безстатевим, безликий і доступний за ціною. Те, що «пупс» був не дівчинкою і не хлопчиком, повністю відповідало установкам педагогіки тих років. Тому діти одягали його за бажанням то хлопчиком, то дівчинкою. 3 роками «пупса» поступово витіснили іграшки з сучасніших матеріалів - целулоїд виявився дуже горючим і небезпечним для дітей [13, с. 102].

Окрім цих іграшок, діти знаходили багатий матеріал у самій природі, що так щедро наділяла їх іграми і забавами. Життя поля, городу, лісу - давала сільським дітям запас всякого роду розваг. Спостереження за домашніми і дикими тваринами, посадкою рослин, ловом комах і т. д. - усе це знайомило дітей $з$ живою природою і служило їм грою - справою.

Повоєнне село не мало змоги створити сприятливі умови для змістовного проведення дозвілля, тому більшість сільських дітей проводили вільний час на вулиці, де вони розважалися з самого ранку і до пізнього вечора. Тут у дітей під руками знаходився багатий матеріал для ігор, тому їх фантазія і творчість мала можливість проявитися.

Питання підготовки та проведення дозвілля дітей - важливий захід повоєнної відбудови і потребував належної уваги всіх інстанцій. Отже, $з$ викладеного можна дійти висновку, що у досліджуванний період в українському селі проведена значна робота зі створення передумов для зростання освітньо -культурного рівня дітей. В той же час дбаючи про організацію дозвілля школярів, влада уміло використовувала його у власних цілях, отримуючи дієві важелі впливу на формування їх світогляду. Однак, незважаючи на ряд недоліків, які мали місце в організації дозвілля та відпочинку, усе ж необхідно віддати належне радянській владі, - вона зуміла в досить короткий термін взяти ситуацію під свій контроль, охопити всіх дітей, зайняти їх навчанням та суспільно-корисною працею, тримаючи під постійним контролем вихователів, часи навчання і відпочинку вихованців.

\section{Список використаних джерел}

1. Богатирчук К. О. Повсякденне життя дітей і підлітків шкільного віку в Українській РСР (друга половина 60-х - перша половина 80-х pp. XX ст.). Дисертація на здобуття наукового ступеня кандидата історичних наук. Національний педагогічний університет імені М. П. Драгоманова. Київ, 2017. 332 с.

2. Анпілогова Т. Ю. Піонерський табірний рух як форма політико-ідеологічного та виховного впливу на радянську молодь (на матеріалах Донбасу). Вісник Луганського національного університету імені Тараса Шевченка. 2009 . № 21 (184). С. 4-8.

3. Державний архів Одеської області у м. Одеса (ДАОО) Ф.11. Оп. 13. Спр. 704. 46 арк.

4. Державний архів Херсонської області у м. Херсон (ДАХО) Ф.1979. Оп. З. Спр. 310.226 арк.

5. ДАОО. Ф.11. Оп. 12. Спр. 278. 141 арк.

6. Одяг і іграшки для дітей. Південна правда. 1945. № 233. 5 грудня. С. 4.

7. В дитячому санаторії. Південна правда. 1946. № 84.23 квітня. С. 3.

8. Іграшки для дітей. Південна правда. 1947. № 85. 27 квітня. С. 4.

9. Выпуск детских игрушек. Бугская Зоря. 1951. № 97. 19 травня. С. 4. 
10. Большая Советская Энциклопедия, М.: Издательство БСЭ, 1953. Т.17. 632 с.

11. Державний архів Миколаївської області у м. Миколаїв (ДАМО) Ф.11. Оп. 12. Спр. 279. 26 арк.

12. Іграшки від яких діти плачуть. Південна правда. 1959. № 193. 2 жовтня. С. 4.

13. Далекие и любимые. Домашний очаг. 2011. № 9. сентябрь. С. 101-102.

\section{References}

1. Bohatyrchuk K. O. Povsiakdenne zhyttia ditei i pidlitkiv shkilnoho viku v Ukrainckii RSR (druha polovyna 60-kh - persha polovyna 80-kh rr. KhKh st.). Dysertatsiia na zdobuttia naukovoho stupenia kandydata istorychnykh nauk. Natsionalnyi pedahohichnyi universytet imeni M. P. Drahomanova. Kyiv, 2017. $332 \mathrm{~s}$.

2. Anpilohova T.Yu. Pionerskyi tabirnyi rukh yak forma polityko-ideolohichnoho ta vykhovnoho vplyvu na radiansku molod (na materialakh Donbasu). Visnyk Luhanskoho Natsionalnoho Universytetu imeni Tarasa Shevchenka. 2009. № 21(184). S.4- 8.

3. Odiah i ihrashky dlia ditei. Pivdenna pravda. 1945. № 233. 5 hrudnia. S. 4.

4. V dytiachomu sanatorii. Pivdenna pravda. 1946. № 84.23 kvitnia. S.3.

5. Ihrashky dlia ditei. Pivdenna pravda. 1947. № 85. 27 kvitnia. S.4.

6. $\quad$ Vupusk detskykh yhrushek. Buhskaia Zoria. 1951. № 97. 19 travnia. S.4.

7. Ihrashky vid yakykh dity plachut. Pivdenna pravda. 1959. № 193. 2 zhovtnia. S.4.

8. Dalekye y liubymue. Domashnyi ochah. 2011. № 9. Sentiabr. S.101-102.

\section{Ревенко В. Формы досуга и отдыха сельских детей в послевоенный период}

В статье проанализированы формы и виды отдыха детей в послевоенный период. Дана характеристика и описание офищиальных и неофищиальных форм досуга. Сделаны выводы, что организованный отдых школьников находился под особым контролем советской власти, которая умело, использовала его в свочх целях, получая действенные рычаги влияния на формирование их мировоззрения. Основное внимание уделялось патриотизма, преданности партии и любви к Родине, трудовому и физическому воспитанию.

Ключевые слова: досуг, отдых, дети, учащаяся молодежь, школьники, идейное воспитание, советская партийная государственная система.

\section{Revenko V. Forms of leisure and recreation of rural children in the postwar period}

The article analyzes forms and types of children's recreation in the post-war period. The description of official and unofficial forms of leisure are given. It turns out that the organized recreation of the schoolchildren were under the special control of the Soviet authorities, who skillfully used it for their own purposes, gaining effective levers of influence on the formation of their outlook. The main attention was paid to the patriotism, devotion to the party and love for the Motherland, labor and physical education. Particularly noted that rural children were often deprived of the opportunity to freely dispose of their free time, they performed work at home, were attracted to doing in collective farms.

The lack of enough pencils, paper and toys was adversely affecting children's leisure time. Insufficient organization of leisure and systematic work with children led to the fact that unaccompanied children were exposed to criminal elements and became the path of hooliganism and crime. In order to overcome child homelessness and crime, the education authorities are effectively managing extracurricular and extracurricular work. However, in spite of a number of shortcomings in the organization of leisure and recreation, the Soviet authorities managed to take control of the situation in a rather short time, to cover all children, to take their studies and socially useful work, under the constant supervision of educators, time of study and rest of pupils.

Keywords: leisure, rest, children, pupils' youth, schoolchildren, ideological upbringing, the Soviet party state system. 
DOI: 10.33310/2519-2809-2019-47-1-24-29

УДК 94(477+(4-6€C):327+323:15

\title{
ЖУЖАННА ДОЛИНАЙ
}

старший викладач

кафедри історії Угорщини та європейської інтеграції, Українсько-угорський навчально-науковий інститут,

Ужгородський національний університет, м. Ужгород

e-mail: zsuzsannadolinai@gmail.com

\section{СПІВРОБІТНИЦТВО МІЖ УКРАЇНОЮ ТА РАДОЮ ЄВРОПИ У ПИТАННЯХ НАЦІОНАЛЬНИХ МЕНШИН}

\begin{abstract}
У статті розглядаються особливості та співробітництва між Україною та Радою Європи у питаннях національних меншин. В Україні гарантії та захист прав національних меншин на законодавчому рівні відповідають міжнародним стаднартам, але є певні недоліки у практищі захисті національних меншин та реголюванні міжетнічних відносини.
\end{abstract}

Ключові слова: Україна, Рада Єворпи, співробітнищтво, національні меншини. права національних меншин.

Історія людства свідчить про те, що міжнаціональні конфлікти та конфліктогенні чиниики $є$ джерелами дестабілізації національного та міжнарододного миру. На початку XXI століття країни-держави світу не є гомогенною як етнічному, культурному та релігійному сенсі.

Європа є мультикультурною, отже одним із ключових завдань $€$ захист національних меншин, Рада Європи розробляє стандарти, що мають обов'язкову силу для держав, які їх визнають. Рада Європи - унікальна міжурядова регіональна організація в Єворпі, метою якої є захист плюралістичної демократії, верховенства права та прав людини, а також регулювання відносини держав-учасниць у питанні, які виникають у суспільстві.

Мета даного дослідження $є$ комплексний аналіз співробітництва між Україною та Радою Європи у питаннях національних меншин. 3'ясування основних проблем у сфері захисті національних меншин в Україні перспекти у рамках Ради Європи та визначення основних перспективів у співпраці у питаннях національних меншин.

Джерельну та літературну базу дослідження складають: конвенції, законодавчі акти; матеріали досліджень іноземних та вітчизняних фахівців; монографії, наукові статTi, тощо. Щодо характеристики наукового стану вивчення проблеми національних мен- шин, дана дослідження аналізувала наукові статті наступних дослідників, Василенко В., Василик Л., Лимонникова М., Мицик В. Договірно-правова база та між Україною та Радою Європи у питаннях національних меншин э потужною [1-12].

Предметом дослідження $\epsilon$ статус національних меншин у Раді Європи та в Украї̈ні, співробітництво між Україною та Радою Європи у питаннях національних меншин.

\section{Завдання дослідження:}

- розкрити особливість етапів розвитку процесу міжнародно-правового регулювання статусу і захисту національних меншин;

- проаналізувати, систематизувати статус національних меншин у Ради Європи;

- на основі науково обгрунтованих критеріїв встановити місце нормативноправового комплексу міжнародного захисту національних меншин у системі сучасного міжнародного публічного права;

- проаналізувати спрівробітництво між Україною та P€;

- проаналізувати Рамкову конвенцію про захист національних меншин;

- дослідити статусу національних меншин у Європейському Союзі;

- розглянути політико-правові проблеми, пов'язані $з$ правом національних меншин на самовизначення. 
Актуальність дослідження полягаяє в тому, міжнародно-правова практика та практика і політико-правові проблеми пов'язані $з$ правом національних меншин на самовизначення та особливості прав національних меншин у їхньому співвідношенні з правами людини, класифікація прав національних меншин в міжнародних документах $\epsilon$ актуальнм i потребує постійного вивчення та аналізу. В Україні гарантії та захист прав національних меншин на законодавчому рівні відповідають міжнародним стаднартам, але $є$ певні недоліки у практиці захисті національних меншин та реголюванні міжетнічних відносини.

Головною метою згідно Статутом Р€ є: сприяння економічному та соціальному прогресу [4].

Важливе значення має демократичний шлях держав в Європі, який заснований на рівноправності, співпраці, довірі й взаємодопомозі сторін: Основною статутною умовою для вступу країн до Р€ $є$ захист прав людини та зміцнення демократичних інститутів. [9].

Наша держава стала членом 37-м членом Організації Комітету міністрів Р€ 24 років тому, тобто 9 листопада 1995 року. Важливо відзначити, що Україна стала стороною декількох конвенцій цієї Організації [9]. Питання про становище національних меншин Рада Європи неодноразово розглядала впродовж більш ніж п'ятдесяти років. Уже в перший рік свого існування, тобто в 1949 р., Парламентська асамблея в доповіді свого Комітету з правових та адміністративних питань визнала важливість "проблеми посилення захисту прав національних меншин" [15, 77 с].

Загальна декларація прав людини від 10 грудня 1948 р., містить основні загальнолюдські права, які передбачали свободу віросподівнання, культурні й політичні права людині (меншини, а міжнародна правова практика свідчить про те, шо прголошенні права у документі відображенні конситицуіях та законах країн-членів 00Н. 2 ст. містить еленементи, які вказуть на те, що «кожна людина має володіти всіма правами і всіма свободами, проголошеними цією Декларацією» [3].

Європейська хартія регіональних мов або мов меншин ухвалена в рамках Ради Європи
5 листопада 1992 р., набула чинності 1 березня 1998 р. взяла на себе зобов'язання дотримуватись у своїй політиці, законодавстві та практиці принципів, спрямованих на розвиток регіональних мов або мов меншин. Головною метою хартії $\epsilon$ культурний розвиток, містить елементи антидискримінаційного застереження, але й передбачає заходи, спрямовані на активну підтримку таких мов.

Метою хартії $\epsilon$ також, наскільки це дозволяють умови, забезпечення вживання регіональних мов або мов меншин у сфері освіти і засобах масової інформації, у судах та адміністративних установах, в економічному та соціальному житті, у культурній діяльності.

Ще одним кроком до впровадження міжнародних стандартів у сфері забезпечення прав національних меншин стала ратифікація 15 березня 2003 р. Верховною Радою України Європейської хартії регіональних мов або мов меншин. Хартія регулює відносини, які виникають під час реалізації громадянами України прав і свобод, пов'язаних з їх належністю до національних меншин, регулюються також чинними міжнародними договорами, згода на обов'язковість яких надана Верховною Радою України і які є складовою національного законодавства України (ст. 9) $[15,209$ с].

Відтак цей документ має стати реальним гарантом забезпечення прав людини в культурно-мовній сфері українського суспільства. Основна дискусія точиться навколо назви Хартії, а точніше, неправильного її перекладу. Так, науковці вважають, що ні про яку мову національних меншин у Хартії не йдеться. Натомість у документі згадується про міноритарні мови, тобто ті, яким справді загрожує зникнення. «Сьогодні у світі існує 6809 мов. Але понад 90\% з них мають менше 100 тис. носіїв, причому 350 мов - менше 50-ти. Ці мови можна було б занести до «Червоної книги», коли б така існувала» [13].

Відзначимо, що частина I-a містить загальні положення та визначає термін "регіональні мови" які традиційно використовуються в межах певної території країни ії громадянами, що складають групу, меншу за чисельністю від решти населення цієї держави. Діалекти офіційної мови держави або мови 
мігрантів до зазначених мов не належать (пп. i-iі п. а ст. 1) [2].

Пункт с ст. 1 визначає термін "нетериторіальні мови" як такі, що використовують громадяни держави і які є відмінними від мови (мов), що використовується рештою населення держави, але які попри їх традиційне використання в межах території держави не можуть вважатися найбільш поширеними в межах конкретної місцевості цієї держави [2].

Ось ці 90\% і є міноритарними, на думку автора статті, які і треба охороняти і розвивати. На цьому наголошує і В. Василенко: «правильним українським відповідником $\epsilon$ «регіональні або міноритарні мови», тобто ті мови, що використовуються у певному регіоні» [12].

Згідно з положенням Хартія застосовуються до таких мов національних меншин України, як білоруська, грецька, єврейська, кримськотатарська, молдавська, німецька, польська, російська, румунська, та угорська. По-перше, двічі названо одну й ту ж мову молдавська та румунська, коли молдавська, на думку більшості науковців, є діалектом румунської; по-друге, грецька мова в Україні не використовується, на сучасному етапі розвитку грецької мови сукупність ї̈ діалектів називають новогрецькою мовою; по-третє, єврейської мови взагалі не існує, наявні окремі єврейські мови: іврит та ідиш, а про яку безпосередньо йдеться - невідомо [16].

Разом $з$ тим В. Василенко вказує, що терміни «регіональна мова» та «міноритарна» дещо перекликаються, але все ж таки це нетотожні поняття [15, с. 107].

Особливість сучасного етапу розвитку захисту прав меншин у діяльності Ради Європи, що бере відлік із кінця 90-х рр. XX ст., полягає в тому, що основні зусилля організації зосереджені радше на реалізації та гарантії чинних стандартів у цій сфері, ніж на розробці нових.

3 часу набуття Рамковою конвенцією про захист національних меншин [8] чинності та початку роботи її моніторингового органу Консультативного комітету - в цій царині було досягнуто значного прогресу. Розробляючи проект РК, Спеціальний комітет приділив особливу увагу політичним зобов'язан- ням стосовно захисту національних меншин, що містяться в копенгагенському документі та в інших актах ОБСЄ (тоді НБСЄ), як було домовлено на Віденському саміті (1993. 8-9 жовтня), якнайширше втілити ці політичні зобов'язання в зобов'язання правові [15, с. 185].

Відзначимо, що Рамкова конвенція про захист національних меншин перша міжнародна багатостороння угода про захист національних меншин, яка підписана 1 лютого 1995 року у Страсбурзі. Унікальність даного договору полягяє у тому, що є першим міжнародно-правовим інструментом, спрямованим на захист прав осіб-членів національних меншин як інтегральної складової прав людини в цілому [8]. 9 грудня 1997 Україна ратифікувала Рамкову конвенцію про захист національних меншин.

Більшість статей Рамкової конвенції закріплюють принципи, що охоплюють велику низку питань, зокрема: заборону дискримінації та забезпечення справжньої рівності; створення умов, необхідних для збереження релігії, мови, традицій; свободу мирних зборів, асоціацій, виявлення поглядів, думки, совісті та релігії; доступ до засобів масової інформації, використання особами свого прізвища та ім'я мовою меншини, а також топографічних покажчиків мовою національної меншини); освітні права (вивчення мови меншини та навчання мовою меншини, свобода створювати навчальні заклади з викладанням мовою меншини); право на транскордонні контакти та співпраця; участь в економічному, культурному та соціальному житті, в державних справах; заборона примусової асиміляції. Деякі з цих принципів є загальними, тобто стосуються прав і свобод кожної людини (заборона дискримінації, свобода мирних зборів, асоціацій, виявлення поглядів, висловлення думок, свобода совісті, релігії та ін.) і закріплюються універсальними міжнародними договорами ООН, Європейською конвенцією з прав людини та іншими регіональними конвенціями в цій сфері. У країнах, де міжнародне право визнається частиною внутрішньодержавного права, такі принципи і норми мають пряму дію. Але особлива увага під час розробки РК приділялася програмним положенням, пряма дія яких у 
національному праві неможлива. Термін "рамкова" вказує на те, що принципи, вміщені в цьому документі, не підлягають безпосередньому застосуванню у внутрішньому праві держав-членів, а мають здійснюватися за допомогою їх імплементації в національне законодавство та відповідну державну політику [15, с. 186].

На нашу думку, унікальність конвенції полягає у наступному:

- рівність перед законом;

- збереження культурної спадщини;

- вільне вираження своїх поглядів, свобода думки і слова;

- розвиток мови меншин та вільне використання іï на території проживання меншин;

- право на освіти та її розвиток;

- вільні транскордонні контакти з особами, з якими об'єднує спільна культурна спадщина;

- участь в економічному, культурному та суспільному житті.

В Україні захист прав національних меншин здійснюється національними правовими актами згідно $з$ міжнародними стандартами та міжнародно-правовими зобов'язаннями країни.

Отже, Рамкова конвенція являє собою найбільш повний конкретизований спеціальний правовий документ, покладений в основу створення загальноєвропейської системи захисту прав національних меншин.

Співпраця між держави-учасниці Рамкової конвенції полягає у тому, що вони визнають право на свободу виявлення поглядів кожної особи, яка належить до національної меншини [11].

Зосереджуючись на Рамковій конвенції про захист національних меншин (РКЗНМ), спільна діяльність була спрямована на підвищення обізнаності обох органів державної влади та громадянського суспільства у сфері прав меншин; було проведено роботу з українськими інститутами задля просування досліджень, що сприяють розвитку стратегічних рекомендацій щодо політики. Рада Європи надає допомогу для розвитку конструктивного діалогу між відповідними міністерствами та представниками національних меншин для розвитку освіти мовою національних меншин, для роботи в напрямку відновлення впевненості меншин в органах державної влади та установах, і надалі підтримуватиме прогрес в сфері прав на освіту і ефективну участь національних меншин у суспільному житті [6].

Сприяння роботі України з Р€ на сьогодні характеризується наступними [10]: реформування чинного і розробка та імплементація нового законодавства у відповідності до стандартів Ради Європи на основі принципів верховенства права та прав людини.

Вкрай важливою є співпраця між Україною та РЄ у принципі рівності у захисті прав людини. Це гарантується Європейською конвенцією з прав людини (ЄКПЛ) (Стаття 14) і посилено Протоколом № 12 до Конвенції, яка була ратифікована Україною в 1997 році. Допомога необхідна для підтримки реформ, особливо щодо реалізації наявних законодавчих та політичних інструментів у цьому полі. Діяльність щодо захисту прав кримських татар буде одним із цільових пріоритетів. Рада Європи бере активну участь у наданні допомоги законодавчій реформі щодо прав меншин, у тому числі щодо можливих поправок до мови законодавства і пакету поправок до боротьби з дискримінацією [6].

Важливим $€$ співробітництво України з Європейською Комісією «За демократію через право» (Венеціанська комісія) є сталою і ефективною формою використання науковоекспертного потенціалу Ради Європи з метою удосконалення національного законодавства у відповідності до європейських стандартів [5].

Підкреслимо, що за роки свого існування Венеціанська комісія підготувала близько 150 висновків та експертних оцінок щодо законопроектів та законів України. Серед найважливіших з них: юридичні висновки щодо проектів Конституції України, Законів України «Про Автономну республіку Крим», «Про Конституційний Суд України», «Про вибори народних депутатів України», «Про Судоустрій» [10].

Згідно до норм Ради Європи залишається ще привести ряд положень національного законодавства, зокрема, щодо повноважень органів прокуратури, створення ефективного 
інституту адвокатури, реформування судової системи [10].

Актуальним $\epsilon$ у співпраці України з $\mathrm{P} €$ головування нашої держави в Комітеті міністрів Ради Європи у травні-листопаді 2011 року, що відбулось вперше за роки членства України в Організації. Під час головування Міністр закордонних справ України К.І. Грищенко обіймав посаду Голови Комітету міністрів Р€ [1]. Підкреслимо, що українському головуванню вдалося досягти такі результати, як сприяння запровадженню країнамичленами комплексних національних стратегій, щодо захисту прав дітей та попередження насильства щодо них [10].

Саме на період українського головування припала найбільш активна фаза другого етапу реформи Ради Європи [10].

За участю України, у 2015-2018 років та підготовки до роботи в найближчі три роки 8 листопада, було проведено щорічну координаційну платформу Рамкової програми співпраці між ЄС та Радою Європи «Партнерство заради належного врядування» для країн Східного партнерства». Термін реалізації усіх нинішніх проектів Програми «Партнерство заради належного врядування для країн Східного партнерства» спливає в Україні до кінця цього року. 3 2019-го стартує їі друга фаза, яка триватиме так само три роки, тобто включно до 2021-го року. Підготовка до неї розпочинається вже сьогодні - 3 підбиття підсумків роботи проектів, що діють в Україні, та обговорення подальших пріоритетів взаємодії в рамках Програми [7].

Аналізуючи співробітництво між Україною та Радою Європи у питанні національних меншин можемо зробити висновок, шо співраця між Україною та Р€ у захисті національних меншин $є$ багатоплановою і ефективною. P€ готова допомогти і підтримувати нашу державу у захисті прав національних меншин як на державному, так і на місцевому рівні. Рада Європи у правовому аспекті вже декілька років допомогає Україні в покращенні захисту меншин, у тому числі на місцевому рівні, перш за все міжнародними стандартами. На сьогодні між Радою Європи та Україною ведуться переговори щодо покращення правової бази стосовно мов національних меншин.

\section{Список використаних джерел}

1. 9 листопада: вступ України до Ради Європи URL: http://www.hroniky.com/news/view/13716-9-lystopada-vstup-ukrainydo-rady-ievropy (дата звернення: 30.03.2019).

2. Європейська хартія регіональних мов або мов меншин URL: http://zakon.rada.gov.ua/laws/show/994_014 (дата 3вернення: 12.04.2019).

3. Загальна декларація прав людини року URL: http://zakon.rada.gov.ua/laws/show/995_015 (дата звернення: 30.03.2019).

4. Зібрання чинних міжнародних договорів України. Київ: 2006. № 5. Ст. 1270. С. 43.

5. Переглянутий Статут Європейської комісії «За демократію через право» прийнятого Резолюцією Комітету міністрів від 21 лютого 2002 p. URL: http://www.venice.coe.int/site/main/Statute_E.asp (дата звернення: 14. 04.2019).

6. План дій для України на 2015 - 2017 pp URL: https://www.kmu.gov.ua/storage/app/media/ugoda-pro-asociaciyu/ planre2015-17ukr.pdf (дата звернення: 03.04.2019).

7. Рада Європи у співпраці з ЄС готується до втілення в Україні другої фази Програми з підтримки URL: https:// www.nrada.gov.ua/rada-yevropy-u-spivpratsi-z-yes-gotuyetsya-vtilennya-v-ukrayini-drugoyi-fazy-programy-z-pidtrymky (дата звернення: 12.04.2019).

8. Рамкова конвенція про захист національних меншин URL: http://zakon.rada.gov.ua/laws/show/995_055 (дата звернення: 02.05.2019).

9. Співробітництво між Україною та Радою Європи.URL: http://www.mfa.gov.uacoeua4544.htm (дата звернення: 18.04.2019).

10. Співробітництво між Україною та Радою Європи.URL: https://coe.mfa.gov.ua/ua/ukraine-coe/cooperation (дата звернення: 18.04.2019).

11. Страсбурзька рамкова конвенція (1994р.) про захист національних меншин. URL: http://lib.chdu.edu.ua/pdf/ metodser/87/64.pdf (дата звернення: 02.04.2019).

12. Василенко В. Які мови в Україні потребують особливого захисту. Колізія між національним законом і міжнародними зобов'язаннями держави. веб-сайт. URL: http://www.dt.ua/newspaper/articles/46241\#article (дата звернення: 02.05.2019).

13. Василик Л. Міноритарна мова? Чи правова неграмотність? веб-сайт. URL: http://h.ua/story/256622. (дата звернення: 03.05.2019).

14. Лимонникова М. А. Венецианская Комиссия Совета Европы : правовые аспекты создания и деятельности: автореф. дис. на здобуття наук. ступеня д-ра юр. наук : 12.00 .10 / МГИМО. М., 2010.25 c. URL:. http://lawtheses.com/ venetsianskaya-komissiya-soveta-evropy. (дата звернення: 03.05.2019).

15. Мицик В.В. Права національних меншин у міжнародному праві: монографія. Київ.: Видавничо-поліграфічний центр "Київський університет", 2004. 287 с. 
16. Янковська Г. В. Історія прийняття й ратифікації в Україні Європейської хартії регіональних мов або мов меншин: проблеми та перспективи. Право і суспільство. 2011. № 3. С. 65-70.

\section{References}

1. 9 lystopada: vstup Ukrayiny do Rady Yevropy: http://www.hroniky.com/news/view/13716-9-lystopada-vstup-ukrainy-dorady-ievropy (data zvernennya: 30.03.2019).

2. Yevropejs"ka xartiya rehionalnyh mov abo mov menshyn: http://zakon.rada.gov.ua/laws/show/994_014 (data zvernennya: 12.04.2019).

3. Zahal"na deklaraciya prav lyudyny roku: http://zakon.rada.gov.ua/laws/show/995_015 (data zvernennya: 30.03.2019).

4. Zibrannya chynnyh mizhnarodnyx dohovoriv Ukrayiny. Kyiv: 2006. № 5. St. 1270. S. 43.

5. Perehlyanutyj Statut Yevropejskoyi komisiyi «Za demokratiyu cherez pravo» pryjnyatoho Rezolyuciyeyu Komitetu ministriv vid 21 lyutoho 2002 r.: http://www.venice.coe.int/site/main/Statute_E.asp (data zvernennya: 14. 04.2019).

6. 6. Plan dij dlya Ukrayiny na 2015 - 2017 rr: https://www.kmu.gov.ua/storage/app/media/ugoda-pro-asociaciyu/ planre2015-17ukr.pdf (data zvernennya: 03.04.2019).

7. Rada Yevropy u spivpraci z YeS hotuyetsya do vtilennya v Ukrayini druhoyi fazy Prohramy z pidtrymky: https:// www.nrada.gov.ua/rada-yevropy-u-spivpratsi-z-yes-gotuyetsya-vtilennya-v-ukrayini-drugoyi-fazy-programy-z-pidtrymky (data zvernennya: 12.04.2019).

8. Ramkova konvenciya pro zaxyst nacional"nyx menshyn: http://zakon.rada.gov.ua/laws/show/995_055 (data zvernennya: 02.05.2019).

9. Spivrobitnyctvo mizh Ukrayinoyu ta Radoyu Yevropy.: http://www.mfa.gov.uacoeua4544.htm (data zvernennya: 18.04.2019).

10. Spivrobitnyctvo mizh Ukrayinoyu ta Radoyu Yevropy: https://coe.mfa.gov.ua/ua/ukraine-coe/cooperation (data zvernennya: 18.04.2019).

11. Strasburz"ka ramkova konvenciya (1994 r.) pro zaxyst nacional"nyx menshyn.: http://lib.chdu.edu.ua/pdf/ metodser/87/64.pdf (data zvernennya: 02.04.2019).

12. Vasylenko V. Yaki movy v Ukrayini potrebuyut" osoblyvoho zaxystu. Koliziya mizh nacional"nym zakonom i mizhnarodnymy zobov'yazannyamy derzhavy. veb-sajt.: http://www.dt.ua/newspaper/articles/46241\#article (data zvernennya: 02.05.2019).

13. Vasylyk L. Minorytarna mova? Chy pravova nehramotnist"? veb-sajt.: http://h.ua/story/256622. (data zvernennya: 03.05.2019).

14. Lymonnykova M. A. Venecyanskaya Komyssyya Soveta Evropы : pravovыe aspektы sozdanyya y deyatel"nosty: avtoref. dys. na zdobuttya nauk. stupenya d-ra yur. nauk: 12.00.10 / MHYMO. M., 2010. 25 s.. http://lawtheses.com/venetsianskayakomissiya-soveta-evropy. (data zvernennya: 03.05.2019).

15. Mycyk V.V. Prava nacional"nyx menshyn u mizhnarodnomu pravi: monohrafiya. Kyiv: Vydavnycho-polihrafichnyj centr "Kyyivskyj universytet", 2004.287 s.

16. Yankovs"ka H. V. Istoriya pryjnyattya j ratyfikaciyi v Ukrayini Yevropejs"koyi xartiyi rehional"nyx mov abo mov menshyn: problemy ta perspektyvy. Pravo i suspilstvo. 2011. № 3. S. 65-70.

\section{Долинай Ж. Сотрудничество между Украиной и Советом Европы В вопросах националь- ных меньшинств}

В статье рассматриваются особенности и сотрудничества между Украиной и Советом Европы в вопросах национальных меньшинств. В Украине гарантии и защита прав национальных меньшинств на законодательном уровне соответствуют международным стаднартам, но есть определенные недостатки в практике защите национальных меньшинств и реголюванни межэтнических отношениях.

Ключевые слова: Украина, Совет Еворпы, сотрудничество, национальные меньшинства. права национальных меньшинств.

\section{Dolinai Z. Cooperation between Ukraine and Council of Europe on issues national minorities}

This thesis examines features and cooperation between Ukraine and the Council of Europe on issues of national minorities. The global and regional international law legal norms in force is perceived as a framework, and humane rights rules as a minimum standards and could not regulate in detail all possible minority situation, than we need at least concrete principles for the interpretation of the existing norms for minority protection. Such principles of interpretation, that given in this thesis, would help decision-makers to use the existing rules in concrete situation.On the 9th of November 1995 Ukraine has joined to the Council of Europe becoming the 37 member of organization.

Ukraine ratified the European Charter for Regional and Minority Languages in 2003. The European Charter for Regional or Minority Languages is the European convention for the protection and promotion of languages used by traditional minorities. Together with the Framework Convention for the Protection of National Minorities it constitutes the Council of Europe's commitment to the protection of national minorities. The co-operation between Ukraine and the Council of Europe in protecting national minorities is multifaceted and effective. The CoE ready to help and support our state in protecting the rights of national minorities at state and local level too. The Council of Europe has been helping Ukraine for several years to improve the protection of minorities, including at local level international standards.

Key words: Ukraine, Europa Council, cooperation, national minorities. rights of national minorities. 
DOI: 10.33310/2519-2809-2019-47-1-30-39

УДК 94(477.62):911.375«19»

\author{
ВАЛЕРІЙ БОГУНЕНКО \\ викладач кафедри вітчизняної та зарубіжної історії \\ Горлівського інституту іноземних мов, \\ м. Бахмут, Україна \\ e-mail: bogunenkovalery@gmail.com
}

\title{
ЕТНОСОЦІАЛЬНІ ТА ГЕОДЕМОГРАФІЧНІ КОДИ ПАМ'ЯТІ МОНОПРОФІЛЬНИХ МІСТ ДОНБАСУ
}

\begin{abstract}
У контексті розвитку вітчизняних студій пам'яті в структурно-поселенському вимірі розглядаються трансформації етносоціальних та геодемографічних кодів пам'яті громад монопрофільних міст Донбасу у ХХ ст. Обгрунтовується регіональна проблематика функціонування зазначених умовно-знакових систем як джерел ідентичності, визначається ї̈ зв'язок з локально-історичним феноменом монопрофільних міст. Розкривається залежність формування кодів пам'яті громад цих населених пунктів від взаємодії комплексу економіко-промислових, адміністративнополітичних, просторово-організаційних та інших факторів. Доводиться, що умови декодування, трансляції та руйнації кодів пам'яті населення монопрофільних міст регіону впродовж головних періодів їх розвитку визначили тут локальну специфіку регіонально-просторової ідентичності.

Ключові слова: студії пам'яті, простір пам'яті, коди пам'яті, етносоціальні коди пам'яті, геодемографічні коди пам'яті, регіонально-просторова ідентичність, Донбас, монопрофільні міста.
\end{abstract}

Пам'яттєвий дискурс є одним із визначальних у суспільно-політичній та соціокультурній сфері сучасної України, оскільки він безпосередньо пов'язаний із окресленням ціннісно-цивілізаційних смислів державнополітичного та національно-культурного розвитку, питаннями ідентичності, ментально-просторового моделювання тощо. У зв'язку з цим у нашій країні, як і в багатьох інших державах Європи, розробляється та реалізується «політика пам'яті».

У новітній історії України регіональна та локальна проблематика студій пам'яті особливо актуалізована у зв'язку 3 воєннополітичними подіями останніх п'яти років на Сході України. Важливою є її етносоціальні та геодемографічні виміри, пов'язані з неусталеністю ієрархії державно-просторової ідентифікації - локальної, регіональної, державної, - мешканців Донбасу (у вузькому значенні - територій Донецької та Луганської областей), у тому числі - представників громад монопрофільних міст регіону.

У контексті визначення «динаміки ідентичностей» та розробки «ментальних мап» України нині вбачається потреба у вивченні пам'яттєвих феноменів населення Донбасу, що складалися тут впродовж XX ст. внаслідок масштабних демографічних, етнокультурних та інших процесів. До них належать коди пам'яті - способи організації простору пам'яті [12, c. 181].

Об'єктом пропонованого дослідження $€$ простір пам'яті громад монопрофільних міст Донбасу; предмет складають етносоціальні та геодемографічні коди пам'яті, пов'язані $з$ часом формування абсолютної більшості таких міст.

Спеціальні дослідження з цієї проблематики відсутні. Серед масиву вітчизняної історичної літератури, де висвітлювалася тема формування та розвитку монопрофільних міст регіону, насамперед слід назвати фундаментальні праці з історії міст та сіл Донецької та Луганської областей, що виходили у 196070-х pp. [7; 10], та працю «История рабочих Донбасса» поч. 1980-х рр. [8; 9], де, незважаючи на ідеологічну заангажованість, були розкриті економіко-промислові умови виникнення населених пунктів, розглянуті певні демографічні та етнокультурні аспекти розвитку регіону в радянські десятиліття.

Серед робіт сучасних вітчизняних авторівдослідників історії Донбасу, що дотичні до 
обраної теми, слід назвати дослідження М. Алфьорова, присвячене проблематиці заселення та урбанізації регіону у XX ст. [1;2]; 3. Лихолобової щодо формування соціальних особливостей регіону в контексті виробничих відносин [13; 15]; дослідження етнополітичних аспектів формування поселенської структури регіону, здійснене Ю. Ніколайцем [16]; працю Г. Коржова, присвячену проблематиці формування регіональної ідентичності Донбасу [13], та ін. Серед зарубіжних дослідників Донбасу значний внесок у розуміння специфіки історії порубіжного регіону в $\mathrm{XX}$ ст. вніс американський історик Г. Куромія.

В останні роки вийшли друком узагальнюючі аналітичні праці, присвячені проблемним, насамперед з воєнно-політичної точки зору, українським регіонам - Донбасу та Криму, - авторства В. Смолія, С. Кульчицького та Л. Якубової. У них визнається необхідність глибокого комплексного вивчення локальних варіантів складання етнокультурної специфіки Донбасу [17]. У зв'язку з цим з-поміж достатньо широкого кола робіт по історії регіону можна виокремити цікаві дослідження К. Кузіної, В. Кулікова, І. Склокіної та ін., присвячені саме промисловим мономістам.

3 методологічної сторони цінними для висвітлення обраної тематики є вітчизняне дослідження колективної пам'яті громад малих міст центральної України авторства 0. Гриценка [4]; аналіз «гетеротопій пам'яті», проведений А. Киридон [11], та ін.

3 метою визначити характерні особливості процесу формування та функціонування геодемографічних та етносоціальних кодів пам'яті громад монопрофільних міст Донбасу у період 1920-80-х рр. необхідно вирішити наступні завдання: визначити місце монопрофільних міст у поселенській структурі та економіці Донбасу; розкрити специфіку етносоціальних та геодемографічних кодів пам'яті; з'ясувати основні фактори формування, збереження, трансляції чи руйнації кодів пам'яті громад малих міст Донбасу в досліджуваний період та розглянути їх дію на різних етапах.

Характерною рисою монопрофільних міст (у літературі вживаються також терміни «монофункціональні міста», «монопромисло- ві міста», «мономіста») є залежність наповнюваності бюджету від діяльності одного чи кількох однотипних «містоутворюючих» підприємств однієї чи споріднених галузей; діяльність інших підприємств, якщо вони існують, спрямована в основному на обслуговування внутрішніх потреб міста. 3 цим пов'язана низька диверсифікація сфери зайнятості населення таких міст. Специфіка монопрофільних міст Донбасу пов'язана з їх місцем у поселенській структурі та економіці регіону. Так, ці міста складають більшість із населених пунктів регіону з адміністративним статусом міста - нині 60 з 89 міст регіону мають монопрофільний характер; сукупне населення цих міст складає більше чверті сукупного населення регіону. Варто зауважити, що більшість сучасних поліфункціональних міст Донбасу таких, як Дебальцеве, Горлівка, Кадіївка (Стаханов), Рубіжне, Сєвєродонецьк, Хрустальний (Красний Луч) та ін. - проходили стадію монофункціональності у 1920-30-ті рр.

Слід зазначити, що в багатьох дослідженнях монопрофільні міста Донбасу насамперед асоціюються з вугільною промисловістю, що обумовлено їх переважаючою кількістю в регіоні, масштабністю соціально-економічної проблематики шахтарських мономіст, пов'язаної з глибокою кризою галузі, починаючи 3 1980-х рр. Це, безумовно, сприяє збереженню за Донбасом стереотипного образу «шахтарського краю». У той же час мономіста Донбасу мають суттєві профільні особливості: промисловість, зосереджена в них, належить, крім вугільної та коксохімічної, до вогнетривкої, цементної, енергетичної, залізничної та інших галузей, $\epsilon$ значною частиною виробничих потужностей регіону та країни загалом. При дослідженні проблематики мономіст Донбасу важливо це враховувати, як і структурні особливості цих міст (що можуть відображатися, в тому числі, в царині локальної пам'яті). Так, це можуть бути населені пункти з одним або з кількома містоутворюючими підприємствами; міста-супутники поліфункціональних міст тощо.

Творення та трансформації варіантів локальної пам'яті суттєво залежить від особливостей «кодів пам'яті» - умовно-знакових систем збереження, відтворення та передачі 
певного соціокультурного змісту. Згідно 3 визначенням цієї категорії «memory studies», котре надає А. Киридон, «код - ...поєднання смислів в один сконцентрований згусток», що забезпечує відновлення деталей «завдяки зберіганню в пам'яті короткого вербального опису або маркера» [12, с. 182]. Дослідниками відзначається наявність регіональних особливостей процесів декодування (що співвідноситься $з$ терміном «діалект пам'яті»), можливість не тільки «перекодування», «перемикання» кодів, проте і їх «стирання» [12, с. 182-183]. Вищезазначені «механізми» можна вважати основою асиміляційних та інших соціокультурних процесів.

Комплексне застосування підходів історичної регіоналістики, урбаністики та студій пам'яті до проблематики монопрофільних міст Донбасу зумовлює необхідність виокремити етносоціальні та геодемографічні коди пам'яті. Специфіка етносоціальних кодів полягає у їх функції збереження і трансляції пам'яті про етнічне походження груп населення та їх співвідношення в умовах конкретних соціальних організмів. У свою чергу, геодемографічні коди пам'яті зберігають інформацію про формування спільнот в окремому географічному районі внаслідок певних демографічних процесів, їх динаміку тощо. Носіями та трансляторами етнонаціональних та геодемографічних кодів, що відтворюють суспільно значущі смисли, можуть бути як окремі індивіди, так і колективи (родинні, професійні, громади міст тощо), інструментами суспільні інститути (школи, музеї, засоби масової інформації тощо). При цьому етносоціальні та геодемографічні за змістом, за формою коди пам'яті можуть бути різними. Так, виділяють візуальні, вербальні, звукові, акціональні, темпоральні, просторові, соматичні, харчові, архітектурно-будівні, релігійні тощо; при цьому коди взаємно актуалізуються, «перетікають» один в одного [12, с. 183].

Вивчення проблематики специфіки формування та функціонування етносоціальних та геодемографічних кодів пам'яті монопрофільних міст регіону у зазначений період потребує розгляду демографічних, етногеографічних факторів, пов'язаних із динамікою міграцій, кількісним та якісним складом на- селення (національним, соціальним тощо), а також порубіжним становищем досліджуваної території. У зв'язку з цим $є$ потреба, насамперед при вивченні формування у населення мономіст геодемографічних кодів пам'яті, у зверненні до просторово-організаційних факторів, пов'язаних із станом поселенської структури на різних етапах розвитку регіону у досліджуваний період.

Також слід враховувати економіковиробничі фактори формування та функціонування в регіоні локальних варіантів етносоціальних та геодемографічних кодів пам'яTi, що визначали галузево-територіальні домінанти регіональної та локальної ідентифікації у періоди найбільшої динамічності заселення регіону в контексті його промислового розвитку. При цьому слід виокремити передусім етапи форсованої індустріалізації (кінець 1920-30-х рр.), «повоєнного призову» (друга пол. 1940-х рр.); етап «комсомольських будов» другої пол. 1950 - середина 1960-х рр.). Визнаючи виключну важливість впливу на функціонування кодів пам'яті громад промислових міст Донбасу загальнодержавних економічних тенденцій, також варто виділити епоху застою (сер. 1960-80-х рр.) «золотого віку вугільної галузі» та період перебудови (з сер. 1980-х рр.), що співпав з наростанням в економіці країни та, відповідно, регіону кризових явищ.

Не менш важливим $\epsilon$ врахування державних культурно-ідеологічних чинників, що визначали розвиток досліджуваної території у періоди «коренізації» 1920-х рр. та її наступного згортання, з середини 1930-х рр., та переходу до «інтернаціоналізації» 3 кінця 1950-х рр.

На початку досліджуваного періоду основним фактором формування населення мономіст Донбасу була трудова міграція. При цьому процеси формування етносоціальних та геодемографічних кодів пам'яті громад цих поселень суттєво залежали тоді від співвідношення місцевих соціокультурних традицій, які складалися в робітничих селищах Донбасу, як регіону етнічного порубіжжя, ще 3 кінця XIX ст. Населення промислових міст Донбасу до середини 1920-х рр. в основному становили українці та росіяни; спочатку відносну 
більшість складали росіяни 3 центральних губерній Росії - близько 51\%; українців було близько $40 \%$, а серед представників інших етносів найбільш чисельними були поволзькі татари, білоруси, євреї [8, с. 255]. У багатьох шахтарських поселеннях, що виникли в XIX ст., більшість працівників складали переселенці 3 російських губерній; 3 двадцяти значних населених пунктів Донбасу лише у Дебальцевому та Слов'янську частка українців переважала. Проте більшість загального населення Донбасу (64\%) на той час становили українці, значно переважаючи серед селян [17, с. 130-132]. Етнодемографічна ситуація у регіоні наприкінці 1920-х р. у п'яти округах (територія котрих увійшла пізніше до Донецької обл.) була такою: українці становили $64,0 \%$, росіяни - 26,1\%; решту складали німці, греки, євреї та ін. (у другій пол. 1920-х - сер. 1930-х рр. тут навіть існували національні райони - чотири грецьких, три російських, німецький, німецько-український) [17, с. 139].

За відомостями 1934 р., серед працівників Донбасу українці складали $52,6 \%$, росіяни $41,2 \%$, представники інших етносів - 5,2\%. Важливо відзначити, що у 1927-37 рр., внаслідок Голодомору, депортацій, відтоку на промислові підприємства суттєво зменшилася кількість населення регіону в аграрних районах Донбасу. Натомість населення міст та селищ Донбасу стрімко зростало - на території багатьох міськрад - більше, ніж удвічі [17, с. 93].

Вплив на етнічну ситуацію на Донбасі впродовж 1930-х рр. здійснили також масові репресії, через що тут зменшилася частка представників окремих етнічних меншин (греків, німців, поляків) [17, с. 162-163]. Натомість, внаслідок діяльності бірж праці, роботи по вербуванню робітників у різних районах СРСР, громадського «призову» тощо на роботу у вугільній промисловості регіону на поч. 1930-х рр., крім українців, прибували росіяни, татари, білоруси, мешканці інших республік [8, с. 247-248].

За доби індустріалізації внаслідок масштабної трудової міграції робітники потрапляли на Донбасі в нову сферу соціальної взаємодії, домінантою котрої у монопромислових населених пунктах була виробничо-галузева специфіка, максимально поєднана 3 просто- рово-організаційною. При цьому в регіоні могли відбуватися складні процеси перекодування, часткового стирання етносоціальних та геодемографічних «кодів пам'яті» переселенців, передусім пов'язаних з аграрною добою. Ці процеси набували особливого забарвлення під час українізації, коли її ідеологами була висунута теза про культурну модернізацію Донбасу, виходячи з «сільських» етнокультурних ресурсів, тобто спираючись на українські «коди пам'яті» аграрної доби. Так, за тогочасними словами М. Скрипника, «колись багато товаришів гадало, що Донбас - це не Україна, а робітники Донбасу здебільше не українці. Виявляється тепер, що це цілком не вірно; серед гірняків $3 / 4$, цебто близько 70 відсотків робітників, українців. До нових заводів, копалень ідуть... сотні тисяч робітників з села, треба, щоб основні кадри донбасівського кваліфікованого пролетаріату оволоділи... українською культурою для того, щоб мати можливість впливати на ці нові робітничі шари» [6, с. 26].

Слід визнати, що вищенаведені очікування не справдилися, натомість уніфікаційні властивості «плавильного казана» промислового регіону, пролетарська соціокультурна традиція діяли ефективно. Важливим чинником трансформацій етносоціальних кодів пам'яті у регіоні в цей час було і те, що росіяни, через належність до пануючого етносу Російської імперії та активну участь у промисловій колонізації Донбасу, не вважали себе тут національною меншиною [17, с. 142]. Це ускладнило українізацію в регіоні, як і соціальні мотиви спротиву їй у промислових містах, коли вона сприймалася просто як «зайвий додаток» до важкої праці [17, с. 138-139].

Такий структурно-поселенський чинник, як утворення та розвиток в регіоні монопрофільних міст під час індустріалізації та урбанізації, вніс свою специфіку у ці процеси. Так, ще з дореволюційного періоду до кінця 1920-х рр. при кожному промисловому підприємстві в Донбасі зводилися робітничі поселення «колонії» з бараків, землянок. Під час індустріалізації, що позначився стрімкою динамікою трудової міграції, виключно промисловість ставала в регіоні містоутворювальним фактором, та навколо підприємств будувалися 
«соцміста» відповідно до принципів та норм організації соціалістичних розселень. Виходячи 3 кількості населення, передбачалося забезпечення потреб робочих та їх родин в медичному забезпеченні, освіті (у т. ч. дошкільній), культурі. При цьому «соцміста», як «пролетарські ядра», накопичуючи, зберігаючи та відтворюючи людський ресурс, були й засобами керування робочими колективами, «виховання нової людини» [2, с. 75-77].

Тоді статус міста отримали понад двадцять монопрофільних населених пунктів. Підприємствам вугільної галузі як містоутворюючим зобов'язані появою на мапі в якості міст Чистякове (1932р.), Ровеньки (1934р.); Артемове (1938 р.), Дзержинськ (1938 р.), Кремінна (1938 р.); Новоекономічне (1938 р.), Моспине (1938 р.), Сніжне та Новий Донбас (1938 р.; згодом ці міста були об'єднані), Гірське (1938 р.), Довжанськ (1938р.), Золоте (1938р.), Ірміно (1936 р.), Краснодон (1938 р.), Паризька Комуна (1938 р.), Первомайськ (1938 р.).

Містоутворюючі підприємства таких міст, Волноваха (1938р.), Дебальцеве (1938р.), Іловайськ (1938р.), Красний Лиман (1938р.), Попасна (1938 р.), Ясинувата (1938 р.), - належали до залізничної галузі; Красногорівки (1938) та Часового Яру (1938 р.) - вогнетривкої; Зугрес (1938р.) - енергетичної; Амвросіївка (1938 р.) - цементної [7; 10].

Слушним $€$ твердження, що «універсальні за своїм змістом процеси етнокультурної універсалізації відбувалися в усіх потужно зростаючих демографічно промислових центpax» [17, с. 145]. У той же час у монопрофільних містах Донбасу були свої відмінності у цій сфері, адже в кожному конкретному місті по-різному складалося співвідношення місцевих мешканців та прибульців-робітників різних етнічних груп; свою специфіку мала інтенсивність їх взаємодії через вікові характеристики тощо. Так, у робітничих селищах, заснованих у дореволюційний час, «кадрові робітники» складали основу формування соціокультурних традицій. Це, зважаючи на переважаючу кількість, до середини 1920-х рр., серед пролетаріату Донбасу росіян, визначило формування відповідного мовного середовища. У той же час у роки індустріалізації (особливо під час першої п'ятирічки) внаслі- док трудової міграції пролетаріат у регіоні суттєво «помолодшав» $[8$, с. 252], тож у новостворених «соцмістах» вплив зазначених соціокультурних традицій був меншим.

Утворення у регіоні мережі монопрофільних міст вплинуло також на формування та розвиток тут специфічних геодемографічних кодів. Загалом внаслідок інтенсивної трудової міграції переселенці на Донбасі в період індустріалізації домінували кількісно [17, c. 134]; сприйняття ними Донбасу як «невідомого краю» (вживаючи вислів героя п'єси Корнійчука «В степах України»), у поєднанні $з$ таким потужним чинником, як стрімка урбанізація, за відповідних ідеологічних, пропагандистських умов визначили у робітничого населення регіону формування кодів пам'яті, пов'язаних з просторовими образами «степи донецкой», що стала територією творення соціалістичної людини. Саме слово «місто» можна вважати маркером, що декодовував у їх мешканців певні новостворені геодемографічні коди тієї доби, та формував у них, порівняно $з$ мешканцями «селищ міського типу», дещо відмінні ідентифікаційні риси. Також виробничо-колективістські маркери на кшталт «заводской проходной» витісняли традиційні для української культури, пов'язані $з$ аграрною символікою. Можливо навіть припустити кодування певних номадичних норм та цінностей у регіональній пам'яті за тієї доби.

У той же час нормоване розселення робітників, розбудова спланованих центрів монофункціональних соцміст групи «В» $[5$, с. 8] тощо визначили в його населення формування рис міської культури, далекої від традиційної (ії можна охарактеризувати як «квазіміську»). В ній панівними стали геодемографічні коди пам'яті, сформовані внаслідок організаційно-просторових особливостей: вживання термінів «посьолок», «колонія», «порядок» тощо стосовно районів міст, які виникли внаслідок злиття поселень; сприйняття у якості «города» виключно новозведеного за спеціальним проектом центру соцміста, та ін.

У повоєнний час, на другому етапі формування та функціонування відповідних кодів пам'яті населення монопрофільних міст 
Донбасу, знову основним чинником, що визначав тут етнодемографічну ситуацію, була трудова міграція. На початок 1944 р. населення Сталінської та Ворошиловградської областей дорівнювало 2960 тис. осіб; до 1955 р. вона збільшилася до 5939 тис. осіб [17, с. 188-189].

Значну кількість мігрантів становили юнаки та дівчата, мобілізовані до ФЗН і ремісничих училищ, та за оргнаборами. Так, лише 3 жовтня 1947 до травня 1948 року за комсомольськими путівками на Донбас прибуло 12 тис. осіб з Житомирської. Київської, Чернігівської та Запорізької областей [7, с. 64]. 3 прибулих більшість складали українці, решту - росіяни, татари, білоруси, молдавани та ін. Помітну частку населення Донбасу у 19441947 р. складали особи, утримувані у фільтраційних таборах (на Донбасі налічувалося 13 таборів), усього їх кількість становила у цей час від 33288 до 110749 осіб. У регіоні значним у цей час було не тільки поповнення, проте й відтік робочої сили [17, с. 191-192].

3 початку 1950-х рр. в регіоні тривало інтенсивне шахтне будівництво; у цей час статус міста отримали шахтарські селища Добропілля (1953р.) та Шахтарськ (1953 р.); також містами стали Докучаєвськ (1954р.), пов'язаний $з$ гірничовидобувною галуззю, та Авдіївка (1956р.) - з коксохімічною [7].

Інтенсивна міграція, зростання частки переселенців серед населення регіону сприяли тут закріпленню сформованих вже у довоєнну добу певних геодемографічних кодів пам'яті, пов'язані з розвитком міської мережі, міською топонімікою тощо. У той же час тогочасні важкі побутово-соціальні умови на Донбасі, особливо під час голоду 1946-47 рр., виснажлива праця на відновленні господарства Донбасу стали передумовою подальшою стрімкої етнокультурної уніфікації в регіоні. Основним же їі чинником дослідники вважають планомірне утвердження у той час у регіоні, внаслідок культурно-освітньої політики держави, двомовності з метою подальшої русифікації [16, с. 164].

У той же час можна стверджувати, що у другій пол. 1940-х - середині 1950-х рр. у монопрофільних містах Донбасу ці процеси мали специфіку завдяки архітектурно-планувальним відмінностям та щільності населен- ня регіону, що зумовило близькість сільського середовища як у топографічному, так і в типологічному значенні (через схожість побуту, ведення багатьма мешканцями «міст» підсобного господарства тощо). Так, за свідченням тогочасного мешканця с. Миколаївка Костянтинівського району Донецької обл., сусіднього з монопрофільним містом вогнетривників Часів Яром, «Часів Яр був для нас столицею, а такі міста, як Артемівськ і Костянтинівка - закордоном. У столиці ми бували кожного дня, більше того - ми наповнювали iї своїми турботами і якоюсь... аурою» [18, c. 81]. Це, через тісну соціальну взаємодію 3 носіями відповідної мовної, аграрнопобутової традиції забезпечувало умови для збереження та декодування у монопрофільних містах певних етносоціальних та геодемографічних кодів пам'яті.

У наступну добу суттєвим чинником зростання населення, крім природного приросту, залишався механічний приріст, тобто трудова міграція. Так, у 1956 р. за «комсомольським призовом» у Донецьку область прибуло понад 8,5 тис. молодих будівельників і шахтарів «з різних районів УРСР» [7, c. 65]. У наступному році Рада міністрів СРСР і ЦК КПРС прийняли постанову «Про громадський призов молоді на роботу у найважливіших будовах, розташованих у східних і північних районах СРСР та Донбасі». Усього на той час на Донбас прибуло близько 85 тис. працівників, у тому числі - з Центральної та Західної України [10, с. 679-680]; завдяки праці близько 6 тис. молодих будівельників з Києва, Херсона, Чернігова і Луганська у Ровеньках були побудовані п'ять шахт - Київськікомсомольські № 1 і № 2, Чернігівськакомсомольська, Херсонська-комсомольська і Луганська-комсомольська [10, с. 740].

«Комсомольські будови» посилили урбанізацію регіону. Наприкінці 1950-х рр. міське населення складало 5500 тис. осіб, тут було 314 міських поселень, [17, с. 199]; більшість становили мономіста та селища міського типу. Останні з 1956 р. «за спрощенною процедурою» ставали «містами», якщо їх населення становило не менше 10 тис. осіб, і переважно було задіяне у промисловому виробництві. Статус міста в регіоні отримали в той час 
монопрофільні шахтарські поселення Вуглегірськ (1958р.), Гірник (1958р.), Білицьке (1966 р.), Білозерське (1966 р.), Юнокомунарівськ (1965р.), Новогродівка (1958р.), Родинське (1962р.), Селидове (1956 р.), Українськ (1963 р.), Кіровське (1958 р.), Антрацит (1962 р.), Вахрушеве (1963р.), Брянка (1962 р.), Червонопартизанськ (1960р.), Кіровськ (1962р.), Зимогір'я (1961р.), Артемівськ (1961р.), Зоринськ (1963р.), Привілля (1963), Новодружеськ (1963р.), Молодогвардійськ (1961р.), Міусинськ (колишнє селище Штергрес, 1965 р.). Також на мапі з'явилися міста пов'язані з енергетичною промисловістю Курахове (1956 р.), Щастя (1963р.); металургійною - Лутугіне (1960р.); солевидобувною - Карло-Лібкхнехтовськ (1965 р.); доломітовою - Яма (1961 р., з 1973 р. - Сіверськ); гірничовидобувною (видобуток флюсового вапняку) - Комсомольське (1956 р.), хімічною - Петровське (1963р.). Також статус міста отримало селище лікувально-оздоровчого профілю Слов'яногірськ (1964р.); окреме місце посідає Новоазовськ (1966 р.), пов'язаний із харчовою промисловістю [7].

Більшість міст із цього переліку, що були пов'язані з вугільною галуззю, зводилися біля комсомольських шахт за спрощеним плануванням; основне їх населення формувалося 3 шахтарів та будівельників молодого віку, що, безумовно, вплинуло на подальшу трансляцію у населення геодемографічних кодів пам'яті про Донбас як колонізовану, «освоєну» землю.

Етнічне співвідношення тут у цілому збігалося з картиною передвоєнного десятиліття. У той же час державна етнокультурна політика щодо регіону з кінця 1950-х рр. отримала виразно русифікаційні риси. Новозведені біля «комсомольських будов» міста знаходилися вже у державно-ідеологічному фокусі розгляду Донбасу як «інтернаціональної родини», частки «радянського народу».

Урбанізаційні процеси наступних етапів призвели до надання статусу міста монопрофільним населеним пунктам регіону. Так, у 1965 р. на мапі Донбасу зявилося шахтарське м. Димитров. У 1972 р. воно було об'єднане з Новоекономічним. Також статус міста отримали поселення, пов'язані з вугільною про- мисловістю - Жданівка (1966р.), Суходільськ (1972 р.) [7]. Соціалістичним містом металургів у 1977 р. стало селище Алмазна. Найпізніше в досліджуваний період, у 1989 р., містом став Вугледар [17, с. 199], у самій назві котрого відображений монопрофільний характер населенного пункту.

У 1970 р. міське населення Донбасу зросло до 6547 тис. осіб; у той же час з 1970-х рр. почався процес депопуляції регіону [17, с. 199]. При цьому частка міського населення в регіоні наприкінці 1970-х рр. наближалася до 90\% [9, c. 297-298]. На трансформації геодемографічних кодів пам'яті населення монопрофільних міст Донбасу у той час могли впливати такі структурно-поселенські чинники, як розвиток цих міст у складі агломерацій, утворення ними разом 3 навколишніми селищами та селами мікрорегіонів.

На етносоціальні коди пам'яті населення регіону продовжував потужно впливати владний курс на «інтернаціоналізацію Донбасу». Прикметно, що велика роль у цьому процесі, крім традиційних засобів ідеологізації, приділялася такому етнодемографічному чиннику, як змішані шлюби. Так, у колективній праці «Історія робочих Донбасса» відмічалося: «Действенным фактором дальнейшей интернационализации населения Донбасса, как и всей страны, являются смешанные (межнациональные) браки, количество которых неуклонно увеличивается. Значение подобных брачных связей состоит в том, что они... способствуют стиранию национальных различий даже в такой традиционно-самобытной сфере, как семейно-бытовая» [9, с. 298]. При цьому слід зазначити, що поширення міжнаціональних шлюбів мало місце в регіоні ще 3 довоєнної доби [16, с. 108].

Загалом владна політика в епоху «комсомольських будов» та «застою», інерція цієї політики в роки «перебудови», безумовно, сприяли стиранню етносоціальних кодів, або їх перекодуванню та витісненню, навіть у межах родин, у сферу генераційної, індивідуальної пам'яті. У той же час можна припустити, що у населення монофункціональних міст абсолютне стирання цих кодів, через особливості повсякдення, наявність виробничоорганізаційних традицій тощо відбувалося не 
3 такою інтенсивністю, як у середніх та особливо великих поліфункціональних містах. Так, наприклад, українські лінгвістичні елементи (приказки, професійне арго тощо) могли перетворюватися в межах локальних соціальних практик (зокрема, виробничих взаємодій) на коди локальної комунікативної памяті.

Таким чином, проблематика етнокультурної, регіонально-просторової ідентичності населення Донбасу пов'язана з локальними пам'яттєвими феноменами. Важливе місце у поселенській структурі регіону займають монопрофільні міста. Впродовж досліджуваного періоду формування специфічних ментальнокультурних рис їх громад визначали етносоціальні та геодемографічні коди пам'яті. При цьому процеси трансляції, декодувань, перекодувань або стирання цих умовно-знакових систем залежали від низки факторів: етнодемографічних, виробничо-соціальних, державно-ідеологічних. Їх характер суттєво змінюва- вся на етапах індустріалізації, «повоєнного призову», «комсомольських будов» та епохи «застою». У результаті у громад монопрофільних міст Донбасу специфіка трансформацій етносоціальних кодів пам'яті виявилася у порівняно меншій «інтернаціоналізації» за більш тісного «виробничого» характеру соціальної взаємодії; геодемографічних - у сприйнятті міст як, переважно, «колоній» трудових мігрантів.

Перспективи подальшого дослідження цієї теми пов'язані з докладним розглядом трансформацій зазначених кодів пам'яті в історії окремих монопрофільних міст, що потребує комплексного застосування методів історичної регіоналістики (насамперед студій пограниччя, локальної історії, урбаністики) та «memory studies». Отримані результати нададуть можливість типологізувати монопрофільні міста Донбасу, визначити наявність у їх соціокультурній сфері суттєвих передумов «конфліктів пам'ятей».

\section{Список використаних джерел}

1. Алфьоров М. А. Міграційні процеси та їх вплив на соціально-економічний розвиток Донбасу (1939-1959 рр.) : монографія. Донецьк : Укр. культурологічний центр, Донецьке відділення Наукового товариства ім. Шевченка, 2008. $192 \mathrm{c}$.

2. Алфьоров М. Політика урбанізації східної України в 1920-1939 роки. Схід. № 1. 2010. С. 75-79.

3. Верменич Я. В. Донбас як порубіжний регіон: територіальний вимір. Київ : Інститут історії України НАН України, 2015. 69 c

4. Гриценко О. Пам'ять місцевого виробництва. Трансформація символічного простору та історичної пам'яті в малих містах України. Київ : К.І.С., 2014. 352 с.

5. Губанов О. В. Композиційно-просторові принципи формування ансамблів 1930-х рр. XX ст. в історичних центрах міст Донбасу: автореф. дис. ... канд. архітектури. 18.00.01; Харк. держ. техн. ун-т буд-ва та архіт. Харків, 2008. 20 с.

6. Дзюба І. Донецька рана України: Історико-культурологічні есеї. К. : Інститут історії України НАН України, 2015. 78 с.

7. История городов и сел Украинской ССР: В 26 т. Донецкая область / АН УССР. Ин-т истории; Гл. редкол.: П. Т. Тронько (пред.) и др. К. : Гл. ред. Укр. сов. энцикл. АН УССР, 1976. 811 с.

8. История рабочих Донбасса. Т. 1. / АН УССР. Ин-т истории; Редкол.: Ю. Ю. Кондуфор (гл. ред.) и др. К. : Наукова думка, 1981. $326 \mathrm{c.}$

9. История рабочих Донбасса. Т. 2. / АН УССР. Ин-т истории; Редкол.: Ю. Ю. Кондуфор (гл. ред.) и др. К. : Наукова думка, 1981. $431 \mathrm{c}$.

10. І Історія міст і сіл Української РСР. Луганська область / АН УРСР. Ін-т історії; Гол. редкол.: Пономаренко Ю. Ф., К. : Голов. ред. УРЕ АН УРСР, 1968. 940 c.

11. Киридон А. Гетеротопії пам'яті. Теоретико-методологічні проблеми студій пам'яті. Київ : Ніка-Центр, 2016.320 с.

12. Киридон А. Коди пам'яті. Національна та історична пам'ять: словник ключових термінів / кер. авт. колективу А. М. Киридон. К. : ДП «НВЦ «Пріоритети», 2013. С. 181-183.

13. Коржов Г. Регіональна ідентичність Донбасу: ґенеза і тенденції розвитку за умов суспільної трансформації. Соціологія: теорія, метод. 2006. - № 4. С. 38-50.

14. Лихолобова 3. Г. Кадри вугільної промисловості (1965-1985 рр.). Нові сторінки історії Донбасу: Статті. Кн. 7. Донецьк, 1999. С. 184-195.

15. Лихолобова 3. Г. Міста Донбасу в роки радянської модернізації: особливості менталітету городян. Нові сторінки історії Донбасу: Зб. статей. Кн. 12. Донецьк : ДонНУ, 2006. С. 93-105.

16. Ніколаєць Ю. О. Поселенська структура населення Донбасу (етнополітичний аспект динаміки). К. : НАН України, Ін-т політ. і етнонац. досліджень ім. І. Ф. Кураса, 2012.187 с.

17. Смолій В., Кульчицький С., Якубова Л. Донбас і Крим в економічному, суспільно-політичному та етнокультурному просторі України: історичний досвід, модерні виклики, перспективи (Аналітична доповідь). К. : Інститут історії України НАН України, 2016. 616 с.

18. Федь А. М. Автопортрет з варіаціями. Часів Яр. Сузір'я талантів: Збірка біографічних нарисів. Часів Яр, 2007. C. 79-83. 


\section{Refrerences}

1. Alf'orov, M. A. (2008), Migracijni procesy ta jikh vplyv na social'no-ekonomichnyj rozvytok Donbasu (1939-1959 rr.) [Migration processes and their influence on the socio-economic development of Donbas (1939-1959)] Ukr. kul'turologichnyj centr, Donec'ke viddilennja Naukovogo tovarystva im. Shevchenka, Donec'k, Ukraine.

2. Alf'orov, M. A. (2010), "Urbanization policy of Eastern Ukraine in 1920-1939". Skhid, 1, 75-79.

3. Vermenich, Jа. V. (2015), Верменич Я. В. Donbas jak porubizhnij region: teritorial'nij vimir. [Donbass as a borderline region: territorial measurement], Instytut istorii Ukrainy NAN Ukrainy, Kyiv.

4. Grycenko, 0. (2014). Pam'jat' miscevogo vyrobnyctva. Transformacija symvolichnogo prostoru ta istorichnoyi pam'jati v malyh mistakh Ukrainy [Transformation of symbolic space and historical memory in the small cities of Ukraine], K.I.S., Kyiv, Ukraine.

5. Gubanov, O. V. (2008.), Composite-spatial principles of ensembles formations in the period of 30 - 50th XX century in the historical centers of Donbass region cities. Abstract of Ph.D. dissertation , the theory of architecture, Kharkov State Technical University of Construction and Architecture, Kharkov, Ukraine.

6. Dzjuba, I. (2015) Donec'ka rana Ukrayiny [Donetsk wound of Ukraine], Instytut istorii Ukrainy NAN Ukrainy, Kyiv.

7. Tron'ko, P. T. (ed.), (1976), History of cities and villages of Ukrainian SCR : In 26 vol.The Donetsk region, Glavnaya redakciya Ukrainskoy sovetskoy encyklopedii AN USSR, Kyiv, Ukraine.

8. Kondufor, Yu. Yu (ed.), (1981), History of workers of Donbas, Vol. 1. Naukova dumka, Kiyv, Ukraine.

9. Kondufor, Yu. Yu (ed.), (1981), History of workers of Donbas, Vol. 2. Naukova dumka, Kiyv, Ukraine.

10. Ponomarenko Yu. F. (ed.), (1968), History of cities and villages of Ukrainian SSR. Luhansk region, Holovna redakciya Ukrayins'koyi rad'anskoyi encyklopediyi AN URSR, Kyiv, Ukraine.

11. Kyrydon A. (2016), Geterotopii pam'jati. Teoretyko-metodologichni problemy studij pam'jati [Heterotopies of memory. Theoretical and methodological problems of memory studies], Nika-Tsentr, Kyiv, Ukraine.

12. Kyrydon A. (2013) "Codes of memory", National and historical memory: a dictionary of key terms, DP NVC "Priorytety", 181-183.

13. Korzhov G. (2006), "Regional identity of the Donbas: genesis and trends of development in the conditions of social transformation", Sociologija: teorija, metod, 4, 38-50.

14. Lykholobova Z. G. (1999), "Staff of the coal industry (1965-1985)”. Novi storinky istorii Donbasu, 7, 184-195.

15. Lykholobova Z. G. (2006), "Cities of Donbas during the years of Soviet modernization: features of the mentality of townspeople", Novi storinky istorii Donbasu, 12, 93-105.

16. Nikolaec' Ju. 0. (2012), Poselens'ka struktura naselenn'a Donbasu (etnopolitychnyj aspekt dynamiky) [Settlement structure of the population of Donbas (ethnopolitical aspect of dynamics)], Instytut politychnykh i etnonacional'nykh doslidzhen' im. I. F. Kurasa NAN Ukrainy, Kyiv, Ukraine.

17. Smolij V., Kul'chyc'kyj S., Jakubova L. Donbas i Krym v ekonomichnomu, suspil'no-politychnomu ta etnokul'turnomu prostori Ukrainy: istorichnyj dosvid, moderni vyklyki, perspektyvy (Analitychna dopovid') [Donbass and Crimea in the economic, sociopolitical and ethno-cultural space of Ukraine: historical experience, modern challenges, perspectives (Analytical report)], Institut istorii Ukrainy NAN Ukrainy, Kyiv, Ukraine.

18. Fed' A. M. (2007) "Self-portrait with variations", Chasiv Jar. Suzir'ja talantiv: Zbirka biografichnych narysiv [Chasiv Jar. Constellation of talents: A collection of biographical essays], Chasiv Jar, Ukraine, 79-83.

\section{Богуненко В. Етносоціальные и геодемографические коды памяти монопрофильных городов Донбасса}

В контексте развития отечественных студий памяти в структурно-поселенческом измерении рассматриваются трансформации этносоциальных и геодемографических кодов памяти общин монопрофильных городов Донбасса в ХХ в. Обосновывается региональная проблематика функционирования данных условно-знаковых систем как источника идентичности, определяется ее связь с локально-историческим феноменом монопрофильных городов. Раскрывается зависимость формирования кодов памяти общин этих населенных пунктов от влияния комплекса экономикопромышленных, административно-политических, пространственно-организационных и других факторов. Доказывается, что условия декодирования, трансляции и разрушения кодов памяти населения монопрофильных городов региона на протяжении главных периодов их развития определили здесь локальную специфику регионально-пространственной идентичности.

Ключевые слова: студии памяти, пространство памяти, коды памяти, этносоциальные коды памяти, геодемографические коды памяти, регионально-пространственная идентичность, Донбасс, монопрофильные города. cities

Bogunenko V. Ethno-social and geodemographic memory codes in Donbas monoprophile

The article deals with the problems of the Donbas space memory transformation in XX century in the structural and settlement dimension. It is substantiated the importance of the chosen theme for defining the value-civilization meanings of the state-political and national-cultural development of Ukraine, in particular in the context of the socio-political, socio-cultural situation of the recent years.

It is proved that the development of the domestic memory studios at the present stage requires the study of the local-historical peculiarities of the «memory codes'» transformations. The «memory codes» are conditional-sign systems of preservation, reproduction and transmission of a certain socio-cultural content. 
In this regard, attention was paid to the phenomenon of ethno-social and geodemographic memory codes of communities in Donbas monoprophile cities in XX century.

The role of these cities in the economic and demographic structure of the region is determined in the work; a preliminary attempt is made to typologize the settlements according to their industrial characteristics and the period of foundation. It is revealed the specificity of the dynamic transformations of the ethnosocial and geodemographic communities' memory codes in these settlements and their dissimilarity from those ones that occurred in other settlements of the region. The dependence of the formation of these differences on the interaction of a set of factors was revealed. The main factors were ethno-demagogic, economicindustrial, state-ideological, spatial-organizational, and industrial-social ones.

It was found out that the conditions for decoding, broadcasting and destruction of the mentioned memory codes in the Donbas monoprophile cities during the main periods of their development were determined by the local specificity of ethno-cultural and state-spatial identity. In the ethno-social dimension, this was manifested in a relatively lesser loss of the national identity features by the inhabitants of these settlements compared with the population of polyfunctional cities in the region. In the geodemographic dimension, this led to the perception of these cities by the community members mainly as colonies of labor migrants.

Keywords: memory studies, memory space, memory codes, ethno-social memory codes, geodemographic memory codes, region-spatial identity, Donbas, monoprophile cities. 


\title{
Розділ 2 \\ ВСЕСВITНЯ ІСТОРІЯ
}

DOI: 10.33310/2519-2809-2019-47-1-40-45

УДК 327(438):303.4

\author{
НАТАЛЯ БУГЛАЙ \\ доктор історичних наук, професор кафедри історії \\ Миколаївського національного університету імені В. О. Сухомлинського, \\ м. Миколаїв, Украӥна \\ e-mail: buglay@ukr.net

\section{ЗОВНІШНЯ ПОЛІТИКА РЕСПУБЛІКИ ПОЛЬЩА В ЗАРУБІЖНІЙ ІСТОРІОГРАФІЇ}

\begin{abstract}
Дослідженням зовнішньої політики Польщі, ї̈ взаємин з іншими державами та міжнародними організаціями в контексті трансформації європейського геополітичного простору чимало займалися зарубіжні науковці. Виходячи з хронологічних рамок кінця ХХ - початку ХХІ ст., дослідницьким пошуком були охоплені наукові студії, створені в 1990-2000-х рр. Так, певне місце в історіографії теми займають напрацювання білоруських та литовських авторів, дослідників із США, Великобританії та інших держав. Масив наукових праць є цілком достатнім для вивчення зовнішньої політики РП, зокрема, пріоритетних їі завдань, пов'язаних з інтеграцією держави до НАТО та ЄС, розбудовою взаємовигідних партнерських взаємин із провідними державами, співпрацею з сусідніми та іншими країнами, міжнародними організаціями.

Ключові слова: Польща, зарубіжна історіографія, наукові студї, зовнішня політика, дослідники, комплексний аналіз.
\end{abstract}

Звернення до потужного зарубіжного історіографічного комплексу, що висвітлює зовнішню політику Республіки Польща $є$ актуальним і передбачає проведення масштабної роботи по його аналізу. Виходячи з хронологічних рамок кінця XX - початку XXI ст., дослідницьким пошуком були охоплені наукові студії, створені в 1990-2000-х рр. Розвідки з політології, соціології, культурології, економічної науки, інших галузей гуманітаристики в цей час та за відповідною тематикою набувають яскраво вираженого міждисциплінарного характеру, відчутно набуваючи, на наше переконання, в такий спосіб у якості. Подібний стан справ відкриває фактично необмежені можливості для об'єктивного висвітлення подій історичних подій, ставить, разом 3 тим, перед дослідниками низку викликів, відповідь на які потребує високого професіоналізму та фахової підготовки.

Зарубіжні науковці активно займалися дослідженням зовнішньої політики Польщі, іï взаємин з іншими державами та міжнародними організаціями в контексті трансформації європейського геополітичного простору. Так, певне місце в історіографії теми займають напрацювання білоруських та литовських авторів. Зважаючи на безпосереднє сусідство з РП та деяку спільність спричинених цим фактом проблем, значне місце в доробку білоруських та литовських науковців займають студії європейської та євроатлантичної інтеграції, білорусько-польських та литовськопольських взаємин, стосунків із Російською Федерацією, регіональної взаємодії, співпраці в рамках єврорегіонів тощо. Так, нашу увагу привернули наукові публікації білоруських авторів С. Греся [9], I. Дорняка [14], в яких аналізуються аспекти двосторонніх взаємин між Білоруссю та Польщею, розвідки А. Русаковича [19] про політику НАТО і ЄС щодо Білорусі крізь призму участі в її реалізації польського чинника, статті В. Снапковського [20], В. Шадурського [26] та ін., у 
контексті аналізу широкого спектру проблем певною мірою характерні висвітленням аспектів зовнішньої політики РП упродовж 19952005 pp., а також їх литовських колег А. Бумблаускаса [27], А. Палєцкіса [18] та ін., яким притаманно звернення до проблем спільної історичної минувшини Литви та Польщі, сьогоденних взаємин між ними.

3-поміж авторитетних у США та далеко за їх межами фахівців у сфері міжнародних відносин увагу привертає перш за все 3. Бжезінський, всесвітньовідомий політолог, соціолог, радник з питань національної безпеки президента Д. Картера [2], наукові дискурси якого незмінно торкаються ситуації у Європі та на пострадянському просторі. У добре відомій праці «Велика шахівниця: американська першість та її стратегічні імперативи» та низці інших досліджень 3. Бжезінський послідовно відстоює думку про те, що зміни, спричинені розпадом соціалістичного табору та ліквідацією СРСР, є надзвичайно вигідними для Польщі, адже відкривають перед нею колосальні можливості для зміцнення геополітичної ваги й утвердження в якості лідера Центрально-Східної Європи: 3 наближенням України до Європи Російська Федерація все більше дистанціюватиметься від європейської політики, водночас охоплена інтеграційними процесами на Європейському континенті Німеччина все більше «поглинатиметься» $€ C$, відповідно, порожнечу, що утвориться внаслідок означених процесів у цій частині світу, «приречена» заповнити РП. Прихильний до зміцнення геополітичної ваги Польської держави, сприятливі для цього перспективи 3. Бжезінський убачав в активізації роботи Веймарського трикутника, до участі в якому, принагідно зауважимо, він вважав за доцільне долучити також і Україну. Звичайно ж, неможливо не згадати зауваження про те, що «без України Росія перестає бути євразійською імперією», яке дуже влучно, на наш погляд, розкриває заангажованість у нашій державі великих сусідів - Росії та Польщі, однаковою мірою зацікавлених у зміцненні своєї геополітичної ваги [3, с. 62].

Про прагнення Польської держави до інтеграції в політичні, економічні та безпекові структури Заходу, утвердження в якості ліде- ра Центрально-Східної Європи йдеться у студіях С. Буранта [4], Ш. Гарнетта [8], X. Тіммермана [21], ін. Прихильні до прагнення офіційної Варшави обійняти позицію регіонального лідера, вони значну увагу приділяють взаєминам Польщі з Україною та погоджуються 3 тим, що незалежна Україна має колосальне значення для загальноєвропейської, регіональної та власне польської безпеки. Прагненням офіційної Варшави максимально убезпечити східний кордон РП у роботі спеціаліста-аналітика держдепартаменту США С. Буранта, приміром, пояснено вихід польсько-українських взаємин на рівень стратегічного партнерства. Водночас політика максимального сприяння, що її по відношенню до євроінтеграційних устремлінь України реалізує польська влада, на переконання С. Буранта, зумовлена не інакше як поширеними на території РП антиросійськими настроями. У дослідженні Ш. Гарнетта [28], співробітника Фонду Карнегі, Україна названа наріжним каменем в арці європейської безпеки, і від того, наскільки стабільною вона виявиться, значно залежить збереження цілісності європейською системою безпеки, - переконаний фахівець. Окрім того, у праці Ш. Гарнетта зауважено, що найважливішим партнером України у Європі є Польща, і підтримка зв'язків співпраці 3 нашою державою є одним із ключових пріоритетів польської зовнішньої політики. Прикметно, що західні автори впродовж тривалого часу розглядали Україну сферою впливу Кремля, і лише зі зміщенням на Схід кордонів Альянсу та зміцненням нашої держави у міжнародній своїй суб'єктності в їх працях вона все більше почала фігурувати як самостійна величина. Що ж стосується західного вектора зовнішньої політики РП, успіхи ії інтеграції до НАТО та ЄС, поглиблення співпраці зі США та провідними державами Західної Європи оцінюються ними, як правило, позитивно.

Проблеми історичного розвитку Польщі в колі держав із регіону ЦСЄ, такої собі «напівпериферії Заходу», проаналізовано у роботі американського славіста польського походження П. Вандича «Ціна свободи. Історія Центрально-Східної Європи від Середньовіччя до сьогодення» [5]. Дослідження англійського історика Н. Дейвіса «Боже ігрище. Історія 
Польщі» [12] привертає увагу аналізом генезису Польської держави від найдавніших часів до сучасності, розглядом внутрішніх трансформацій та позиціонування держави на міжнародній арені. Кращому розумінню розбудови РП у контексті викликів, характерних для регіону Центрально-Східної Європи у період по розпаду Радянського Союзу, покликані сприяти також роботи М. Вахудової [6], ж.-Б. Дюрозеля [15], П. Джонсона [13], М. Кундери [16], колективна праця М. Даудерштадта, А. Геррітса, Д. Маркуса [11], ін.

Виходячи з того, що впродовж аналізованого періоду розбудова Польської держави незмінно була пов'язана з Європейським Союзом, початково - в аспекті підготовки до вступу, згодом - зміцнення як державичлена, історіографічним аналізом було охоплено низку наукових студій провідних зарубіжних учених-фахівців у сфері європейської інтеграції - М. Араха «Європейський Союз: бачення політичного об'єднання» [1], В. та Г. Волесів «Творення політики в Європейському Союзі» [7], Д. Дайнена «Дедалі міцніший союз. Курс європейської інтеграції» [10], Ф. Тоді «Нарис історії Європейського Союзу» [22] та ін. У своїй сукупності вони значно посприяли комплексному розумінню історії європейської інтеграції, спрямованості її розвитку, передумов та причин поповнення $€ C$ новими членами, а також наслідків у регіональному й глобальному масштабі, до яких спричинили означені процеси.

I, нарешті, відзначимо дослідження добре відомих знавців геополітики та історії міжнародних відносин С. Хантінхтона [25], Ф. МороДефаржа [17], А. Тойнбі [23], Ф. Фукуями [24], опрацювання яких закладає підгрунтя для комплексного осмислення історичного поступу Європи та світу в цілому, розширює уявлення про події та процеси на глобальному рівні, під впливом яких Республіка Поль- ща реалізовувала зовнішню свою політику. Так, більшість дослідників проблеми слідом за С. Хантінхтоном схильні розглядати Польщу органічною складовою західної цивілізації та позитивно оцінювати ії долучення до Європейського Союзу. Загальносхваленою також $\epsilon$ думка про те, що Польща потрібна Європейському Союзу не менше, ніж ЄС потрібен їй самій. У цілому ж, європейський вибір зовнішньої політики РП виявився тим чинником, навколо успіхів реалізації якого офіційній Варшаві вдалося об'єднати суспільство, а заразом суттєво підвищити авторитет держави на міжнародному рівні.

Отже, наукові роботи зарубіжних дослідників (білоруських, литовських, американських, британських та ін.), проаналізовані у статті, свідчать, що вивчення зовнішньої політики РП упродовж 1995-2005 рр., і надалі викликає інтерес не лише в Україні та Польщі, але й у інших країнах. В наявності достатня кількість розвідок, що дозволяє ретельно проаналізувати зовнішньополітичні пріоритети РП, яка завдяки вдалим реформам, збалансованості внутрішньої і зовнішньої політики, подоланню корупції, претендує на роль лідера Центрально-Східної Європи. Звернення до зарубіжної історіографії допомагає осмислити головні цілі й завдання зовнішньополітичної діяльності Польщі на міжнародній арені, зміст і форми ії відносин із сусідніми та іншими державами та міжнародними організаціями. I хоча роботи різні за змістом i характером, особливо в оцінці вступу РП до НАTO і $€$, наявності здобутків і перспектив на цьому шляху, ролі в зовнішній політиці країни президента А. Кваснєвського та співробітництва РП у рамках транскордонного і міжрегіонального співробітництва, всі вони заслуговують на увагу і спонукають до продовження наукових пошуків по темі дослідження.

\section{Список використаних джерел}

1. Арах М. Европейский Союз: видение политического объединения: пер. с слов. Москва: Экономика, 1998. 466 с.

2. Бжезінский 3. Велика шахівниця: американська першість та її стратегічні імперативи. Івано-Франківськ: Лілея-НВ, 2000. 236 c.

3. Буглай Н. М. Епоха Кваснєвського в зовнішній політиці Республіки Польща (1995-2005 рр.): монографія. Миколаїв: Іліон, 2017. 432 c.

4. Бурант С. Р. Україна і Польща: до стратегічного партнерства // Політична думка. 1997. № 3. С. 99-111.

5. Вандич П. Ціна свободи. Історія Центрально-Східної Європи від Середньовіччя до сьогодення. Київ: Критика, 2004. 464 с.

6. Вахудова М. А. Нерозділена Європа: демократія, важелі впливу та інтеграція після комунізму / [пер. 3 англ. Т. В. Цимбал]. Київ: ВД «Києво-Могилянська академія», 2009. 379 с. 
7. Волес В., Волес Г. Творення політики в Європейському Союзі / [пер. з англ. Р. Ткачук]. Київ: Вид-во Соломії Павличко «Основи», 2004. 871 с.

8. Гарнетт Ш. Перекрестки Европы: Россия, Запад и новые сопредельные государства // США - Канада: Экономика. Политика. Культура. 1999. № 3-4. С. 84-113.

9. Гресь С. М. Белорусско-польские отношения: история формирования и перспективы развития [Электронны рэсурс] // Беларуска-польскія адносіны: гісторыя і сучаснасць: Матэрыялы міжнар. круглага стала (Мінск, 30 кастр. 2014 г.) / В. Г. Шадурскі (адк. рэд.). Мінск: Выд. цэнтр БДУ, 2015. С. 51-55. URL:http://www.elib.bsu.by/ bitstream/123456789/110737/1/gres_2014_BelPol.pdf.

10. Дайнен Д. Дедалі міцніший союз. Курс європейської інтеграції / [пер. з англ. М. Марченко]. Київ: К. І. С., 2006. 692 с.

11. Даудерштадт М., Геррітс А., Маркус Д. Драматичний перехід: соціал-демократія у Східній та Центральній Європі / [пер. з англ.]. Київ: Основні цінності, 2000. 232 с.

12. Дейвіс Н. Боже ігрище: історія Польщі / [пер. з англ. П. Таращук]. Київ: Вид-во Соломії Павличко «Основи», 2008. 1080 с.

13. Джонсон П. Современность. Мир с двадцатых по девяностые годы. В 2-х ч. Ч. 2. Москва: Изд-во «Ануби»; ТОО «Вилад», 1995. $479 \mathrm{c}$.

14. Дорняк И. И. Проблема белорусско-польского экономического и культурного сотрудничества в 1991-2005 гг. в оценке белорусской историографии. Веснік Гродзенскага дзяржаўнага ўніверсітэта імя Янкі Купалы. Серыя 1. Гісторыя $і$ археалогія. Філасофія. Паліталогія. 2013. № 1 (144). С. 54-63.

15. Дюрозель Ж.-Б. Історія дипломатії від 1919 року до наших днів / [пер. з фр. Є. Марічека, Л. Погорєлової, В. Чайковської]. Київ: Основи, 1995. 903 с.

16. Кундера М. Трагедія Центральної Європи [Електронний ресурс] // «Ï». 1995. № 6. URL: http://www.ji.lviv.ua/n6texts/ kundera.htm.

17. Моро-Дефарж Ф. Введение в геополитику. Москва: Конкорд, 1996. 431 с.

18. Палецкис А. Блеск и нищета литовской дипломатии [Электронный ресурс]. URL: http://baltron.ru/news/blesk_i_nishheta_litovskoj_diplomatii/2016-09-30-87.

19. Русакович А. Роль Польши и Германии в формировании общей политики ЕС по отношению к Беларуси [Электронный ресурс] // Центр изучения внешней политики и безопасности: сайт. URL: http://ru.forsecurity.org/ роль-польши-и-германии-в-формирова-нии-общей-политики-ес-по-отношению-к-беларуси.

20. Снапковский В. Белорусско-российские отношения на рубеже столетий (конец 1999 - начало 2001 г.) [Электронный ресурс] Белорусский журнал международного права и международных отношений. 2001. № 2. Сведения доступны также по Интернету. http://portalus.ru/modules/belarus/rus_readme.php?subaction=showfull\&id=1096042265\&archive $=\&$ start_from $=\& u$ cat $=20 \&$ category $=20$.

21. Тиммерман Х. Европейский Союз и его «новые соседи» [Электронный ресурс] // Россия в глобальной политике. 2005. № 4. Июль-август. URL: http://www.globalaffairs.ru/print/number/n_5464.

22. Тоді Ф. Нарис історії Європейського Союзу / [пер. з англ. М. Марченко]. Київ: К. І. С., 2001. 136 с.

23. Тойнби А. Постижение истории. Москва: Айрис-Пресс, 2010. 640 с.

24. Фукуяма Ф. Конец истории и последний человек / [пер. с англ. М. Б. Левина]. Москва: АСТ «Ермак», 2005. 588 с.

25. Хантингтон С. Столкновение цивилизаций / [пер. с англ. Т. Велимеева]. Москва: АСТ: Астрель, 2011. 571 с.

26. Шадурский В. Внешняя культурная политика Республики Беларусь: состояние и проблемы. Белорусский журнал международного права и международных отношений. 2000. № 4. Сведения доступны также по Интернету:http:// portalus.ru/modules/belarus/rus_readme.php?subaction=showfull\&id=1096041490\&archive=\&start_from $=\& u$ cat $=20 \&$ category $=20$.

27. Bumblauskas A. Koncepcja ULB Jerzego Giedroycia: spojrzenie z Litwy / [red. A. Nikzentitis, M. Kopczyński] // Dialog kultur pamięci w regionie ULB. Warszawa: Muzeum Historii Polski, 2014. S. 40-60.

28. Garnett S. Keystone in the Arch: Ukraine in the emeriging security environment of Central and Eastern Europe. Washington DC: Carnegie Endowment for International Peace. 1997.145 p.

\section{References}

1. Arakh M. (1998). Yevropeyskiy Soyuz: videnie politicheskogo obedineniya: per. s slov [European Union: a vision of political unification]. Trans. from words. Moscow: Ekonomika, 466 [in Russian].

2. Bzhezinskyj Z. (2000). Velyka shakhivnycja: amerykansjka pershistj ta jiji strateghichni imperatyvy [Great chessboard: American championship and its strategic imperatives]. Ivano-Frankivsk: Lileya-NV, 236 [in Ukrainian].

3. Bughlaj N. M. (2017). Epokha Kvasnjevsjkogho v zovnishnij polityci Respubliky Poljshha 1995-2005 [The era of Kwasniewski in the foreign policy of the Republic of Poland 1995-2005]. A monograph. Nikolaev: Ilion, 432 [in Ukrainian].

4. Burant S. R. (1997). Ukrajina i Poljshha: do strateghichnogho partnerstva. Politychna dumka [Ukraine and Poland: Strategic Partnership]. Political Thought. № 3. P. 99-111 [in Ukrainian].

5. Vandych P. (2004). Cina svobody. Istorija Centraljno-Skhidnoji Jevropy vid Serednjovichchja do sjoghodennja [Freedom Price. History of Central and Eastern Europe from the Middle Ages to the present]. Kyiv: Kritika, 464 [in Ukrainian].

6. Vakhudova M. A. (2009). Nerozdilena Jevropa: demokratija, vazheli vplyvu ta integhracija pislja komunizmu. Per. z anghl. T. V. Cymbal [Undivided Europe: Democracy, Levers of Influence and Integration after Communism]. Trans. from English T. Tsymbal. Kyiv: VD «Kiyevo-Mogilyanska akademiya», 379 [in Ukrainian].

7. Voles V., Voles Gh. (2004). Tvorennja polityky v Jevropejsjkomu Sojuzi. Per. z anghl. R. Tkachuk [Creation of a policy in the European Union]. Trans. from English R. Tkachuk. Kyiv: Vid-vo Solomiyi Pavlichko «Osnovi», 871 [in Ukrainian].

8. Garnett Sh. (1999). Perekrestki Yevropy: Rossiya, Zapad i novye sopredelnye gosudarstva. SShA - Kanada [Crossroads of Europe: Russia, the West and new contiguous states. USA - Canada]. Economics. Politics Culture. № 3-4. P. 84-113 [in Russian].

9. Gres S. M. (2015). Belorussko-polskie otnosheniya: istoriya formirovaniya i perspektivy razvitiya. Elektronny resurs [BelarusianPolish relations: the history of formation and development prospects]. Electronic resource. Belarusian-Polish relations: Past and Present: Proceedings of the Intern. Roundtable. Minsk, 30 kastr. 2014. V. G. Shadurski. Minsk: Vyd. centr BDU, P. 51-55. Retrieved from http://www.elib.bsu.by/bitstream/123456789/110737/1/gres_2014_BelPol.pdf. [in Belarussian]. 
10. Dajnen D. (2006). Dedali micnishyj sojuz. Kurs jevropejsjkoji integhraciji. Per. z anghl. M. Marchenko [The ever stronger union. European integration course]. Trans. from English M. Marchenko. Kyiv: K. I. S., 692 [in Ukrainian].

11. Daudershtadt M., Gherrits A., Markus D. (2000). Dramatychnyj perekhid: social-demokratija u Skhidnij ta Centraljnij Jevropi. Per. $z$ anghl. [Dramatic transition: Social-Democracy in Eastern and Central Europe]. Trans. from English. Kyiv: Osnovni cinnosti, 232 [in Ukrainian].

12. Dejvis N. (2008). Bozhe ighryshhe: istorija Poljshhi. Per. z anghl. P. Tarashhuk [God's merry-go-round: the history of Poland]. Trans. from English P. Tarashchuk. Kyiv: Vid-vo Solomiyi Pavlichko «Osnovi», 1080 [in Ukrainian].

13. Dzhonson P. (1995). Sovremennost. Mir s dvadtsatykh po devyanostye gody [Modernity. World from the twenties to nineties]. In 2 hours. Part 2. Moscow: Izd-vo «Anubi»; T00 «Vilad», 479 [in Russian].

14. Dornyak I. I. (2013). Problema belorussko-polskogo ekonomicheskogo i kulturnogo sotrudnichestva v 1991-2005 v otsenke belorusskoy istoriografii [The problem of Belarusian-Polish economic and cultural cooperation in 1991-2005 in the assessment of Belarusian historiography]. Bulletin of Hrodna State University. Series 1. The history and archeology. Philosophy. Politics. № 1 (144). P. 54-63 [in Belarussian].

15. Djurozelj Zh.-B. (1995). Istorija dyplomatiji vid 1919 roku do nashykh dniv. Per. z fr. Je. Maricheka, L. Poghorjelovoji, V. Chajkovsjkoji [History of diplomacy from 1919 to the present]. Trans. from Fr. E. Maricek, L. Pogorelova, V. Tchaikovska. Kyiv: Osnovi, 903 [in Ukrainian].

16. Kundera M. (1995). Traghedija Centraljnoji Jevropy. Elektronnyj resurs [Tragedy of Central Europe]. Electronic resource. «Yi». № 6. Retrieved from http://www.ji.lviv.ua/n6texts/kundera.htm [in Ukrainian].

17. Moro-Defarzh F. (1996). Vvedenie v geopolitiku [Introduction to Geopolitics]. Moscow: Konkord, 431 [in Russian].

18. Paletskis A. (2016). Blesk i nishcheta litovskoy diplomatii. Elektronnyy resurs [Glitter and poverty of Lithuanian diplomacy]. Electronic resource. Retrieved from http://baltron.ru/news/blesk_i_nishheta_ litovskoj_diplomatii/2016-09-30-87 [in Russian].

19. Rusakovich A. Rol Polshi i Germanii v formirovanii obshchey politiki YeS po otnosheniyu k Belarusi. Elektronnyy resurs [The role of Poland and Germany in the formation of a common EU policy towards Belarus]. Electronic resource. Center for the Study of Foreign Policy and Security: retrieved from http://ru.forsecurity.org/роль-польши-и-германии-в-формирова-нии-общей -политики-ес-по-отношению-к-беларуси [in Russian].

20. Snapkovskiy V. (2001). Belorussko-rossiyskie otnosheniya na rubezhe stoletiy konets 1999 - nachalo 2001. Elektronnyy resurs [Belarusian-Russian relations at the turn of the century late 1999 - early 2001]. Electronic resource. Belarusian Journal of International Law and International Relations. № 2. Retrieved from http://portalus.ru/modules/belarus/rus_readme.php? subaction=showfull\&id=1096042265\&archive $=\&$ start_from $=$ \&ucat $=20 \&$ category $=20$ [in Russian].

21. Timmerman Kh. (2005). Yevropeyskiy Soyuz i ego «novye sosedi». Elektronnyy resurs [The European Union and its «new neighbors»]. Electronic resource. Russia in global politics. № 4, July-August. Retrieved from http://www.globalaffairs.ru/ print/number/n_5464 [in Russian].

22. Todi F. (2001). Narys istoriji Jevropejsjkogho Sojuzu. Per. z anghl. M. Marchenko [Essay on the history of the European Union]. Trans. from English M. Marchenko. Kyiv: K. I. S., 136 [in Ukrainian].

23. Toynbi A. (2010). Postizhenie istorii [Comprehension of history]. Moscow: Ajris-Press, 640 [in Russian].

24. Fukuyama F. (2005). Konets istorii i posledniy chelovek. Per. s angl. M. B. Levina [The end of the story and the last person]. Trans. from English M. B. Levin. Moscow: AST «Ermak», 588 [in Russian].

25. Khantington S. (2011). Stolknovenie tsivilizatsiy. Per. s angl. T. Velimeeva [Clash of Civilizations]. Trans. from English T. Velimeeva. Moscow: AST: Astrel, 571 [in Russian].

26. Shadurskiy V. (2000). Vneshnyaya kulturnaya politika Respubliki Belarus: sostoyanie i problemy [External cultural policy of the Republic of Belarus: state and problems]. Belarusian Journal of International Law and International Relations. № 4. Retrieved from http://portalus.ru/modules/belarus/rus_readme.php?subaction=showfull\&id=1096041490\&archive=\&start_ from $=\&$ ucat $=20 \&$ category $=20$ [in Belarussian].

27. Bumblauskas A. (2014). Koncepcja ULB Jerzego Giedroycia: spojrzenie z Litwy. Red. A. Nikzentitis, M. Kopczyński. Dialog kultur pamięci w regionie ULB. Warszawa: Muzeum Historii Polski, 2014. S. 40-60.

28. Garnett S. Keystone in the Arch: Ukraine in the emeriging security environment of Central and Eastern Europe. Washington DC: Carnegie Endowment for International Peace. 1997.145 p.

\section{Буглай Н. Внешняя политика Республики Польша в зарубежной историографии}

Исследованием внешней политики Польши, ее взаимоотношений, с другими государствами и международными организациями в контексте трансформации европейского геополитического пространства немало занимались зарубежные научные работники. Исходя из хронологических рамок конца XX - начала XXI вв., исследовательским поиском были охвачены научные студии, созданные в 1990-2000-х г2. Так, определенное место в историографии темы занимают наработки белорусских и литовских авторов, исследователей, из США, Великобритании и других государств. Массив научных трудов является полностью достаточным для изучения внешней политики РП, в частности, приоритетных ее заданий, связанных с интеграцией государства к НАТО и ЕС, перестройкой взаимовыгодных партнерских взаимоотношений с ведущими государствами, сотрудничеством с соседними и другими странами, международными организациями.

Ключевые слова: Польша, зарубежная историография, научные студии, внешняя политика, исследователи, комплексный анализ.

\section{Buglay N. Foreign policy of Republic is Poland in foreign historiography}

By research of foreign policy of Poland, its mutual relations, with other states and international organizations in the context of transformation of European geopolitical space quite a bit foreign research workers 
got busy. Coming from the chronologic scopes of end XX - to beginning of XXI item, by a research search scientific studios, created in 1990-2000th, were overcame. A certain place in historiography of theme is occupied by works of the Byelorussian and Lithuanian authors, researchers, from the USA, Great Britain and other states. An array of scientific labours is fully sufficient for the study of foreign policy of RP, in particular, its foreground jobs, related to integration of the state to NATO and EU, re-erecting of mutually beneficial partner mutual relations with the leading states, by a collaboration with nearby and other countries, international organizations.

Because of direct neighbourhood from RP and some community of the problems caused by this fact, a considerable place in work of the Byelorussian and Lithuanian research workers is occupied by the studios of European and evroatlantichnoy integration, Byelorussian-Polish and Lithuanian-Polish mutual relations, relationships with Russian Federation, regional co-operation, collaboration, within the framework of the European regions and others like that. Western authors examine transformation of foreign-policy course of Poland in the side of western values as such which changed consisting of businesses of country on the best, successes of its integration with NATO and EU of deepening of collaboration with the USA and leading states of Western Europe are estimated by them, as a rule, positively.

Coming from that during an analysable period, re-erecting of the Polish state was unchanging related to European Union, initially - in the aspect of preparation to the entry, afterwards is strengthening as a state-member, by a historiography analysis the row of scientific studios of leading foreign scientistsspecialists was overcame in the field of European integration. In the aggregate they considerably assisted the complex understanding of history of European integration, orientation of its development, preconditions and reasons of addition to EU, new members, and also consequences in a regional and global scale, to which entailed the noted processes.

Keywords: Poland, foreign historiography, scientific studios, foreign policy, researchers, complex analysis. 
DOI: 10.33310/2519-2809-2019-47-1-46-51

УдК 327.39(4)

\author{
GВА КІШ \\ доктор історичних наук, професор, \\ завідувач кафедри історії Угорщини та європейської інтеграяиії, \\ Українсько-угорський навчально-науковий інститут, \\ Ужгородський національний університет, м. Ужгород \\ член зовнішньої колегії Академії Наук Угорщини \\ e-mail: kish.eva15@gmail.com

\section{ЄВРОПЕЙСЬКІ ПРИНЦИПИ ТА ФУНКЦЇ̈ ЄВРО-РЕГІОНАЛЬНОГО ТА ТРАНСКОРДОННОГО СПІВРОБІТНИЦТВА}

\begin{abstract}
Сутність адаптації євро-регіональної та транскордонної політики в України, полягає в реалізації саме головних принципів європейської регіональної політики ЄС та формуванні інституційних основ - інфраструктури регіонального розвитку згідно європейських принципів. 3 точки зору здійснення євро-регіональної та транскордонної політики, важливим $є$ реалізація саме головних принципів європейської регіональної політики: субсидіарності, децентралізації, партнерства, концентрації, адиціоналізму, конвергенції. Актуальність питання визначається з прагматичної точки зору щодо реалізації євро-регіональної політики для України.
\end{abstract}

Ключові слова: Європейський Союз, Україна, регіон, кооперація, принципи, функції, інтеграція.

Європейський Союз у XXI столітті намагається формувати таку стратегію розвитку регіональної політики, яка б базувалася на наявних можливостях і за допомогою якої можна було би посилити конкурентоспроможність регіонів та паралельно ліквідувати їх відсталість. Принципи євро-гіонального i транскордонного співробітництва визначаються також основоположними документами Європейського Союзу, а також щодо політики нового сусідства після розширення Євроспільноти.

Насамперед, Послання Європейської Комісії «Розширена Європа - Сусідні країни: Нова структура відносин з нашими східними та південними сусідами» [11] від 11 березня 2003 року та Послання Європейської Комісії «Прокладаючи шлях для запровадження нового Інструмента регулювання відносин 3 країнами-сусідами» від 1 липня 2003 року [6].

Дані документи визначають необхідність формування біля нових зовнішніх кордонів розширеного Євросоюзу добросусідського середовища та смуги безпеки, миру і співробітництва, а також визначають ключові завдання співробітництва $€ \mathrm{C}$ із новими сусідами, в т. ч. Україною та два етапи впроваджен- ня фінансових та інших інструментів його підтримки.

Власне головними детермінантами нової «філософії» стратегії регіональної політики $€ \mathrm{C}, \mathrm{\epsilon}$ :

- важливість саме економічних інтересів, а не соціальних чинників;

- розвиток приватного підприємництва, малого та середнього бізнесу;

- реалізація не великомасштабних регіональних проектів, а передача регіонального планування «нижчим» територіально-адміністративним одиницям;

- посилення інноваційної спроможності самих регіонів;

- вироблення нових механізмів стосовно регулювання депресивних територій.

Відзначимо, що сутність адаптації єврорегіональної та транскордонної політики в України, полягає в реалізації саме головних принципів європейської регіональної політики $€ C$ та формуванні інституційних основ - інфраструктури регіонального розвитку нашої держави згідно європейських принципів. В цьому сенсі лише зазначимо, що нам недоцільно черговий раз «винаходити велосипед», позаяк регіональна політика навіть в державах Ц€ розробляється і впроваджується 
згідно критерій Європейського Союзу. Утім, це не означає повної імплікації структури регіональної політики Євросоюзу, адже останні суттєво відрізняються за просторовими, і особливо за економічними ознаками.

Дослідження проблемних питань імплементації європейських принципів та функцій євро-регіонального та транскордонного співробітництва здійснюються переважно економісти, зокрема це наукові дослідження Чужикова В. І. [15], монографічне дослідження щодо розкриття стану, тенденцій та проблем розвитку регіонів, результативності діючих механізмів державного регулювання розвитку регіонів України, за редакцією д.е.н., проф. Варналія 3. С. [10]; наукові розвідки вчених Інституту регіональних досліджень НАН України [4; 9; 14], а також і комплексні наукові розробки Інституту Схід-Захід (ЄвроРегіо) стосовно євро-регіонального розвитку, вивчення досвіду регіональної політики $Є С$ та країн $€ C[1 ; 2 ; 5 ; 7]$. Потужним $€$ доробок наукових досліджень вчених Європи [16; 17; 18].

Втім, конкретно реалізації принципів євро-регіональної політики, аналізу інструментів, механізмів її реалізації у вітчизняній науці приділяється вкрай мало уваги.

Метою дослідження $\epsilon$ аналіз принципів і функцій євро-регіональної та транскордонної політики Європейського Союзу, iї складових, механізмів за умов поглиблення та поширення європейського інтеграційного процесу.

Актуальність питання визначається 3 прагматичної точки зору щодо реалізації євро-регіональної політики для України, і постає у наступному вимірі - чи зможуть прикордонні регіони України використати так звані переваги периферійності за нових геополітичних умов, за умов розвитку нового формату взаємовідносин вже у площині, в першу чергу, прикордонні регіони України та прикордонні регіони ЄС. Певна річ, якщо додати i міжрегіональну співпрацю регіонів, тоді палітра нових взаємовідносин стосується не лише прикордонних регіонів України. І питання знов полягає втім чи готові регіони України підключитися до ефективної взаємовигідної співпраці з європейськими регіонами згідно європейських стандартів та критеріїв, чи на- лежною $є$ розбудова інституційних основ євро-регіональної та транскордонної політики України. Концептуально євро-регіональна політика України є важливою з точки зору активної участі України в європейському регіональному, міжрегіональному, транскордонному співробітництві вже нової Європи у XXI столітті. Адже згідно Маастрихтської угоди, принцип субсидіарності $\epsilon$ базовим для $\epsilon C$ (ст.3): «У сферах, які не входять до окремої юрисдикції співтовариства, воно згідно принципу субсидіарності починає свою діяльність лише в тому випадку і постільки, оскільки неможливо у достатній мірі досягнути цілі визначених заходів на рівні держав-членів, i тому в силу їх масштабу чи дієздатності можуть бути здійснені більш ефективно на рівні співтовариства» [3].

Поряд із субсидіарністю, саме децентралізація, як перерозподіл повноважень регіонів 3 метою їх ефективного використання. Важливість цих двох принципів безперечна. Адже їх реалізація посилює відповідальність на місцевому рівні та активізує локальні ініціативи. В цьому контексті посилення місцевої компетенції важливо і з точки зору послаблення (чи зниження) надмірного впливу національного рівня. Важливо, щоб ці рівні стали прозорими [2].

Партнерство $є$ співробітництвом між суб'єктами різних рівнів (Евросоюз, держава, регіон) територіально-адміністративних одиниць 3 часу визначення мети до завершення реалізації конкретного проекту. Цей принцип базується на тій умові, що діяльність та розвиток регіонів може здійснюватися лише тоді (власне тоді ж реалізується і принцип субсидіарности), коли суб'єкти співробітництва постійно та послідовно співпрацюють 3 метою досягнення спільної мети.

Розробка на основі партнерства стратегій розвитку з урахуванням пріоритетних довгострокових та короткострокових цілей є сутністю програмуванням. У регіональній політиці Європейського Союзу принцип партнерства визначає пріоритет інвестування не окремих проектів чи дій, а програм, які мають глибинний вплив на розвиток усього регіону. Стратегія територіального програмування базується на чітко розробленій системі цілей. 
Програмування - це цілеспрямований процес послідовного виконання певних кроків від визначення мети до повної реалізації проекту, що також створює умови для більшої прозорості джерел, їх координації у просторі і часі та їх моніторингу [2].

Ці два принципи - концентрація та адиціоналізм мають взаємодоповнюючий характер і головною умовою ставлять кооперування та ефективне використання ініціатив.

Набуття українськими прикордонними регіонами європейських норм і принципів співпраці, а також і загальноєвропейської інституційної складової не $\epsilon$ можливим без врахування єдиної класифікації регіонального устрою Європейського Союзу - NUTS (Nomenclature of Territorial Units for Statistical Purposes). Ця європейська класифікація з 1988 року не тільки ранжує регіони Євросоюзу, але сприяє і планування та моніторингу фінансування проектів транскордонних регіонів $\epsilon_{\mathrm{B}}$ ропейського Союзу. Статистично-територіальні одиниці ЄС диференціює регіони за обсягом, за соціально-економічним рівнем, демографічними та іншими показниками, усього NUTS - як ієрархічна класифікація, включає три регіональні (NUTS I, II, III) та два локальні (NUTS IV, V) рівні: NUTS I: макрорегіони, регіони; NUTS II: мезорегіони, адміністративні одиниці; NUTS III: округи; NUTS IV: piвень маленьких територій; NUTS V: населені пункти, поселення. Найбільші у масштабному вимірі і найменші у кількісному значенні регіони - це регіони моделі рівня статистичної територіальної номенклатури NUTS-1 [2].

В контексті реалізації єврорегіональної політики визначальним $є$ виокремлення функцій регіонів, позаяк функціональну складову регіонів слід розглядати комплексно і в контексті визначення регіону як найбільш важливого резерву для внутрішньої єдності $\epsilon_{\mathrm{B}-}$ ропейського Союзу. Саме цей аргумент $є$ дуже важливим навіть з політичної точки зору. Важливість цих функцій, а також і статус, що надається регіонам, зокрема, acquis communautaire - як збереження забезпечених досі досягнень співтовариства, полягає втім, що навіть для узгодженого переходу компетенції і відповідної зміни окремих прав на рівні прийняття рішень, що характеризує процес «знизу вверх» (bottom up) інтеграції від націй до співтовариства, необхідні єдині правила.

Комплементарна функція є головним завданням регіонів, що пов'язано із процесом європейської інтеграції взагалі. Європеїзація як процес призводить до зміни усієї системи взаємозв'язків - ролі, компетенції співвідношення функцій органами виконавчої влади, модифікується система прийняття рішення національними органами влади, що 3 усією чіткістю проявилося вже у процесі ратифікації Маастрихтської угоди. Саме в цьому відношенні виявляється доповнююча, комплементарна функція регіонів, що залежить від «ваги» певної держави в структурі Євросоюзу [2].

Функція сумісності регіонів важливою $\epsilon$ в контексті пошуків саме інтенсивних форм співробітництва на всіх рівнях всередині $\Theta_{\text {в- }}$ ропейського Союзу. Розмір адміністративного об'єднання має важливе значення для держави і в меншій мірі це стосується регіону. Наприклад, в Німеччині відмінність між розмірами регіонів більш значна, ніж в централізованих державах, де адміністративне і регіональне планування вимагає стандартизованих розмірів об'єднань $[1 ; 2]$.

Доцільно виокремити такий важливий сегмент як вимога самодостатності для регіонів. Безперечно, що регіони можуть відчути на собі і глобальні впливи (негативні і позитивні наслідки) розвитку ринкової економіки, а модернізація може відбуватися на рівні декількох невеликих регіонів з метою набуття самодостатності серед європейських регіонів, адже взагалі пріоритет мають регіони, що отримали компетенцію, відповідну до їх значення і розміру для прийняття рішень. Регіони можуть посилити своє значення декількома засобами, які наприклад зосереджуються у горизонтальній кооперації та рівності інтересів. Першочергово це відбувається в національних державах, через національні кордони та на рівні ЄC. Адже міжнаціональна кооперація передбачає (у теоретичній площині), що досягнуті угоди підписані в інтересах територій. Хоча це може призвести до створення альянсів чи союзів навколо політичних партій, для того, щоб посилити позицію регіону в конституційній структурі держави, тому важливим $\epsilon$ ступінь до якого мають піднятися європейські регіони - з розробленими ініціативами і кон- 
цептуальними рішеннями саме з метою посилення свого впливу.

Функція «підштовхування» регіонів полягає в першочерговій здатності у посиленні спільних елементів на місцевому рівні. Вироблені в цьому контексті регіональні стратегії мають сприяти формуванню та вирішенню таких проблем регіону, коли компетенція вирішення належить саме регіонам $[1 ; 2]$.

В процесі розвитку мережі зв'язків регіонів, як функції, виявляється здатність регіонів створювати зв'язки в різних сферах на основі рівноправ'я та партнерства. Як позитив, слід відзначити, що передумовою таких зв'язків $\epsilon$ відсутність перешкод для реалізації «внутрішньої» та «зовнішньої» політики регіонів. Принцип регіонального партнерства, визначається зокрема ступенем активності населення регіону, діяльністю асоціацій, соціальних акторів і розвитку ними своїх ідей для загальних цілей регіонального розвитку [1;2].

Регіональну політику ЄС доцільно аналізувати саме в контексті євроінтеграції. Хоча процес регіоналізації і відбувається здебільше на національному рівні і сприяє зміцненню субнаціональних зв'язків, а процес євроінтеграції відбувається на наднаціональному рівні, втім ці два процеси є взаємопов'язаними і в деякій мірі на сьогодні узгоджуються, наприклад, у досягненні консенсусу, що надає адекватну компенсацію інтересам окремих учасників, а також виявляється у конвергенції домовленостей в процесі формування єдиного економічного, монетарного союзу, оскільки потреби перерозподілу теж визначаються регіональною політикою.

Дослідження головних принципів, завдань та механізмів реалізації регіональної політики Європейського Союзу є важливим, адже: чітко визначає перспективи міжрегіонального та транскордонного співробітництва України з Європейським Союзом; імплементація принципів регіональної політики ЄС у національне законодавство України сприятиме реалізації зовнішньополітичної мети України - прискорить євроінтеграційний поступ країни.

Важливою складовою нової регіональної політики $€ \mathrm{C} €$ конвергенція - наближення економічних стандартів країн і регіонів ЄС до рівня провідних економічно розвинутих держав Європи та забезпечення економічного зростання на тривалу перспективу.

Конвергенція - вельми важливе питання для нових країн-членів $€ C$ не тільки економічного (а навіть політичного) характеру, адже веде до істотних змін власне в управлінні економікою, адже значна частка функцій i повноважень передається наднаціональним владним структурам $€ \mathrm{C}$.

Конвергенція (від лат. convergentio - наближення) міждисциплінарне поняття в сенсі зближення не тільки різних економічних систем та нівеляції відмінностей між ними. Нині конвергенція включає також широкий спектр, так би мовити, неекономічних чинників - проблемних питань розвитку соціальної сфери, освіти, культури, новітніх технологій, охорони довкілля тощо. ВВП на душу населення - не єдиний показник конвергенції. Мета конвергенції - вирівнювання диспропорцій між різними державами, підтримка слаборозвинутих регіонів, де ВВП на мешканця менше, ніж 75\% середнього по ЄС.

Критерії конвергенції мають збалансувати розвиток економічного та монетарного союзу, запобігаючи виникненню напруження між країнами-членами. Комісія та Європейський центральний банк періодично готують звіти щодо виконання зазначених критеріїв [13].

Узагальнюючи, можливо зробити наступні висновки. На сьогодні транскордонне співробітництво в Європі включно і в Україні знаходиться на новому етапі розвитку і демонструє якісні зміни. Внаслідок східного розширення $€ С$, транскордонне співробітництво набуло нового геополітичного статусу. Успішна реалізація спільної регіональної політики, $є$ можливою лише в контексті реалізації принципів субсидіарності, а також в більш ширшому розумінні - в контексті будівництва «Європи регіонів».

Безумовно, що ефективна єврорегіональна інтеграція через транскордонне співробітництво суттєво розширить базу включення України до європейських інтеграційних процесів. Перспективи подальших досліджень вважаємо здійснити щодо імплементації регіональної політики ЄС в країнах Центральної Європи. 


\section{Список використаних джерел}

1. Кіш Є. Транскордонне співробітництво та регіональна політика Європейського Союзу // На шляху до Європи. Український досвід Єврорегіонів. Інститут Схід-Захід. Київ: Логос, 2000. С. 13-34.

2. Кіш Є.Б. Регіональна політика Европейського Союзу: стратегічні імперативи для України. Незалежний культурологічний журнал Ï. Львів, 2002. № 23. [Електронний ресурс] Режим доступу: http://www.ji.lviv.ua/n23texts/kish.htm

3. Консолідовані договори ЄС. Київ: Port-Royal, 1999.

4. Мікула Н.А. Стратегія формування та підтримки розвитку транскордонних кластерів. Соціально-економічні проблеми сучасного періоду України. Збірник наукових пращь. Вип. 3 (71). Львів, 2008. С. 129-141.

5. На шляху до Європи. Проект Київського центру Ін-ту Схід-Захід / за ред. С.Максименка. Київ: Логос, 2000. 224 с.

6. Повідомлення Європейської Комісії. Прокладаючи шлях для запровадження нового Інструмента відносин з країнами -сусідами. Brussels, 1 липня 2003 р. СOM(2003) 393 final.

7. Регіональна політика в країнах Європи. Уроки для України. Інститут Схід-Захід. Київ: Логос, 2000.171 c.

8. Регіональна політика ЄС [Електронний ресурс] Режим доступу: // http://europa.eu.int/comm/regional_policy.

9. Регіональна політика: методологія, методика, практика // НАН України Інститут регіональних досліджень. Редколегія.: відповідальний редактор академік НАН України Долішній М.І. Львів, 2001. 700 с.

10. Регіони України: проблеми та пріоритети соціально-економічного розвитку / За редакцією д. е.н., проф. Варналія 3.С. Київ, 2005.

11. Розширена Європа - Сусідні країни. Нова структура відносин з нашими східними та південними сусідами. (11.03.2003) Повідомлення Європейської Комісії для Ради та Європейського Парламенту. http:// www.delukr.cec.eu.int/ua/eu_and_country/bilateral_relations.htm.

12. Розширення Європейського Союзу: вплив на відносини України з центральноєвропейськими сусідами. Інститут регіональних та євроінтеграційних досліджень «ЄвроРегіо Україна». К: «К.І.С.», 2004. 360 с.

13. Словник-довідник Європейського Союзу. Київ: К.І.С. Інформація. Сервіс, 2001.

14. Соціально-економічні дослідження в перехідний період. Регіональна політика: досвід Європейського Союзу та його адаптація до умов України (Збірник наукових праць).Вип.5.(XLIII).B 3-х ч. / НАН України. Інститут регіональних досліджень. Ч. ІІІ, Львів, 2003.

15. Чужиков В. І. Регіональні інтеграційні стратегії постсоціалістичних країн Європи. К. : ТОВ Кадри, 2003. 297 с.

16. An Enlarged Europe. Regions in Competition? (edited by Sally Hardy, Mark Hart, Louis Albrechts, Anastasios Katos) Regional Studies Association. London, 1995.

17. Anderson, Malcolm. The agenda for police cooperation In: Policing across national boundaries, 1994.

18. Bjorn Hettne Globalisation and the new regionalism: The second great transformation / ed. Bjorn Hettne. London, MacMillan Press, 1999.

\section{References}

1. Kish Y. Transkordonne spivrobitnytstvo ta rehionalna polityka Yevropeyskoho Soyuzu // Na shlyakhu do Yevropy. Ukrayinskyy dosvid Yevrorehioniv. Instytut Skhid-Zakhid. Kyiv: Lohos, 2000. S. 13-34.

2. Kish Y.B. Regionalna polityka Evropeyskoho Soyuzu: stratehichni imperatyvy dlya Ukrayiny. Nezalezhnyy kulturolohichnyy zhurnal Y. Lviv, 2002. № 23. [Elektronnyy resurs] Rezhym dostupu: http://www.ji.lviv.ua/n23texts/kish.htm.

3. Konsolidovani dohovory. Kyiv: Port-Royal, 1999.

4. Mikula N. A. Stratehiya formuvannya ta pidtrymky rozvytku transkordonnykh klasteriv. Sotsialno-ekonomichni problemy suchasnoho periodu Ukrayiny. Zbirnyk naukovykh prats. Vyp. 3 (71). Lviv, 2008. S.129-141.

5. Na shlyakhu do Yevropy. Proekt Kyyivskoho tsentru In-tu Skhid-Zakhid / za red. S.Maksymenka. Kyiv: Lohos, 2000. 224 c.

6. Povidomlennya Yevropeyskoyi Komisiyi. Prokladayuchy shlyakh dlya zaprovadzhennya novoho Instrumenta vidnosyn $\mathrm{z}$ krayinamy-susidamy. Brussels, 1 lypnya 2003 r. SOM (2003) 393 final. 7.

7. Rehionalna polityka v krayinakh Yevropy. Uroky dlya Ukrayiny. Instytut Skhid-Zakhid. Kyiv: Lohos, 2000.171 c.

8. Rehionalna polityka [Elektronnyy resurs] - Rezhym dostupu: // http://europa.eu.int/comm/regional_policy.

9. Rehionalna polityka: metodolohiya, metodyka, praktyka // NAN Ukrayiny Instytut rehionalnykh doslidzhen. Redkolehiya: vidpovidalnyy redaktor akademik NAN Ukrayiny Dolishniy M.I. Lviv, 2001. 700 s.

10. Rehiony Ukrayiny: problemy ta priorytety sotsialno-ekonomichnoho rozvytku./ Za redaktsiyeyu d. e.n., prof. Varnaliya Z.S. Kyiv, 2005.

11. Rozshyrena Yevropa - Susidni krayiny. Nova struktura vidnosyn z nashymy skhidnymy ta pivdennymy susidamy. (11.03.2003) Povidomlennya Yevropeyskoyi Komisiyi dlya Rady ta Yevropeyskoho Parlamentu. http:// www.delukr.cec.eu.int/ua/eu_and_country/bilateral_relations.htm.

12. Rozshyrennya Yevropeyskoho Soyuzu: vplyv na vidnosyny Ukrayiny z tsentralnoyevropeyskymy susidamy. Instytut rehionalnykh ta yevrointehratsiynykh doslidzhen «Yevro-Rehio Ukrayina». K: «K.I.S.», 2004. 360 s. 1.

13. Slovnyk-dovidnyk Yevropeyskoho Soyuzu. Kyiv: K.I.S. Informatsiya. Servis, 2001.

14. Sotsialno-ekonomichni doslidzhennya v perekhidnyy period. Rehionalna polityka: dosvid Yevropeyskoho Soyuzu ta yoho adaptatsiya do umov Ukrayiny (Zbirnyk naukovykh prats).Vyp.5. (XLIII).V 3-kh ch. / NAN Ukrayiny. Instytut rehionalnykh doslidzhen. CH. III. Lviv, 2003.

15. Chuzhykov V.I. Rehionalni intehratsiyni stratehiyi post·sotsialistychnykh krayin Yevropy. K. : TOV Kadry, 2003. 297 s.

\section{Киш Е. Европейские принципы и функции евро-регионального и трансграничного со- трудничества}

Суть адаптации евро-региональной и трансграничной политики в Украине заключается в реализации именно главных принципов европейской региональной политики и формировании институционных основ - инфраструктуры регіонального развития согласно европейских принципов. 
С точки зрения реализации евро-региональной и трансграничной политики, важным есть реализации именно главных принципов европейской региональной политики: субсидиарности, децентрализации, партнерства, програмирования, концентрации, адищионализма, конвергенции. Актуальность вопроса определяется пргматически относительно реализации еврорегиональной политики в Украине.

Ключові слова: Європейський Союз, Украӥна, регіон, кооперація, принципи, функцї, інтеграція.

Kish Yeva. European principles and functions of euro-regional and trans-frontier cooperation

The possibilities of trans-frontier collaboration of the regions have become very perspective especially during the transition period. The paper touches the main problems and perspectives of the implementations of European principles in trans-frontier cooperation in the Ukrainian regions.

Euro-regional cooperation between neighboring countries on both regional and local levels has become the most important element of European policy. Thus, the development of common concept papers for transborder cooperation between the bordering regions is a vital issue for the border territories of Ukraine and its first-rate neighboring countries.

The strategic goal of the regional participation in trans-border collaboration is the creation of a highly effective socially oriented economic system of market type on the basis of favorable investment climate. This economic system must be able to develop itself and to motivate increasing of human activity, which is the main factor of improvement of population's material prosperity, as well as to create the necessary conditions for integration into world economic community. The main aim of trans-frontier cooperation of Ukrainian regions, located near border, is to use outer integration factor in order to overcome the negative tendencies of social and economic development of near-frontier regions, to achieve the stabilization of social situation, and to create the necessary basis for increase of industry, employment, activation of investment processes in the priority spheres of economic activity.

It is ascertained that the place and role of international and interregional co-operation in the modern system of international relations is rationally to consider in the context of strategic national-state interests and foreign policy actions directed to providing and implementing of the mentioned interests. It is determined that the strategic aim of interregional cross-border co-operation is direction to strengthening of the state in general through harmonized complex development of regions and deepening of their participation in international integration processes.

Effectiveness of trans-frontier collaboration from the Ukrainian side will depend a lot on the effectiveness of realization of new policy conception, appointed in the legislative acts. The main point of it lies not in the administrative manipulations, but in reasonable decentralization of power and distribution of responsibilities and finances from social and economic viewpoint.

Key words: European Union, Ukraine, region, cooperation, principles, functions, integration. 
DOI: 10.33310/2519-2809-2019-47-1-52-56

УДК 94(4-6 ЄC):327.39

\author{
ЄВА КІШ \\ доктор історичних наук, професор, \\ завідувач кафедри історії Угорщини та європейської інтеграції, \\ Українсько-угорський навчально-науковий інститут, \\ Ужгородський національний університет, м. Ужгород \\ член зовнішньої колегії Академії Наук Угорщини \\ e-mail: kish.eva15@gmail.com
}

\title{
ЖОФІА ДОРГАЙ
}

Магістр історії

кафедри історії Угорщини та європейської інтеграції, Українсько-угорський навчально-науковий інститут,

Ужгородський національний університет, м. Ужгород e-mail: zsofiacska16@gmail.com

\section{ПЕРСПЕКТИВИ МАЙБУТНЬОГО РОЗВИТКУ ЄВРОПЕЙСЬКОГО СОЮЗУ}

\begin{abstract}
На сьогодні актуальною проблемою європейської системи міжнародних відносин є майбутній розвиток Європейського Союзу. Європейський Союз пройшов складний шлях розвитку. Все більше $i$ більше думок існує стосовно питань майбутнього розвитку Європейського Союзу, зокрема, як «єдності у різноманітті», що станом на сьогодні є також дискусійним. Даній темі дослідження приділяється все більше уваги, як з боку експертів, політологів та міжнародників, а також і громадянами європейського континенту. Проблемними питаннями $є$ - глобалізація, економіка, міграція, внутрішні реформи тощо.

Ключові слова: Європейський Союз, інтеграція, ідентичність, міграція, співробітнищтво.
\end{abstract}

Зміни, які відбуваються на сьогодні в Європейському Союзі, можуть мати безпосередній або опосередкований вплив на наше життя. Більше того, визначаючи євро-інтеграційний поступ України в активній проєвропейській зовнішній політиці, актуальні проблемні питання Євросоюзу мають вплив і на Україну. Таким чином, актуальність теми полягає не тільки власне для перспектив розвитку даної міжнародної організації, але і в тому, що європейська інтеграція відіграє ключову роль в політиці України.

Дослідженню проблемних питань європейської інтеграції присвячено багато праць, як вітчизняними дослідниками, так і зарубіжними вченими. Питанням $Є С$ присвячено роботи О. П. Дергачова, А. I. Кудряченко, В. Є. Мармазова, Г. М. Немирі, І. С. Піляєва, Г. М. Перепелиці, В. О. Чалого та інших. Безперечно, праці закордонних вчених мають більш ширшу палітру, що презентовано у до- слідженнях Х. Грабба, А. Інотаї, Ф. Камерона, I. Кемпе, Дж. Хелман, Л. Чабою, Дж. Шерра, А. Вендта, С. Краснера, Р. Кеохейна, П. Сміта, П. Тейлор, А. Фішлоу та інших. Втім, акцентуємо уваги саме на дослідження сучасного проблемного та стратегічного характеру. Конкретно окресленню науково обгрунтованих перспектив майбутнього розвитку Європейського Союзу чи ії̈ напрямів окремих політик $€ С$, у вітчизняній науці приділяється вкрай мало уваги і тільки на рівні публікацій.

Наприклад, питання європейської ідентичності у наявних дискусіях існує у контексті - чи існує єдина європейська ідентичність, якщо так, то яка, і які їі специфічні риси. На думку іспанського філософа Хосе Ортега-уГассета, ідентичність європейського народу є двоякою: вони належать до національної та європейської спільноти одночасно. Європейське суспільство $є$ реальністю, а не вигадкою, і її членами $є$ не нації, а їх члени, особи [7]. 
Однак, на думку деяких інших авторів, Європейський Союз $€$ «незграбною» конструкцією, i ï держави-члени та населення не можуть мати здорового глузду на будь-якому рівні. Ця організація повинна раціонально створювати свідомість ідентичності, щоб вона також означала Ії зростання. Втім, на ідентифікаційну свідомість не можна впливати, вона грунтується на спільному минулому, історичному досвіді. Вона передбачає прийняття яскравих і темних періодів Європи, а не лише поваги до традицій і славних особистостей. Отже, на думку деяких експертів, сама ідентичність абсурдна концепція. За словами Уве Персксена, цей термін також слід вилучити з користування. Люц Нітхаммер вважає, що, на його думку, ідентичність $є$ лише небезпечною фікцією, яка хоче лише призначити індивідів соціальній групі, їх довільним цілям [3, с. 7].

Проте, у XXI столітті більшість конфліктів визначається навколо проблеми ідентичності. Це також не дивно, оскільки суперечки про національну ідентичність та поняття ідентичності залишалися актуальними з початку XX-го століття та після Другої світової війни. На думку аналітиків, наше століття буде століттям претензій щодо ідентичності, що значно збільшить кількість цих внутрішніх конфліктів. Іншими причинами $\epsilon$ те, що в порівняно невеликій Європі дуже багато національностей. Дійсно, у більшості випадків це також поширене і на рівні країн. Як цілком слушно зазначив Хантінгтон, в час краху цивілізацій, цю сучасну ситуацію можна назвати «крахом ідентичностей» [4].

Метою дослідження є аналіз перспектив майбутнього розвитку Європейського Союзу. А також виходячи з мети, вкрай важливим $\epsilon$ дослідження європейської ідентичності та принципу єдності, окреслення дилеми: федерація або держава в контексті інтересів та цінностей.

Проблематичним $\epsilon$ визначення системи і форм ЄC, тому це виклик для бачення національної держави чи федерації. Той факт, що він змінювався кілька разів з моменту свого існування та структури, не кажучи вже про зміну суб'єкта з-поміж держав-членів, це також ускладнювало його розвиток. Можливо, це здається трохи закритою і незрозумілою системою, адже з одного боку вона вимагає глибоких історичних знань про розуміння розвитку ЄС, а з іншого боку, суспільство постійно розширює свою інформацію, а замість цього втрачає свої забобони. В очах звичайних європейських громадян, Союз часто виявляється ще однією бюрократичною інституцією, яка, крім того, займає набагато менше врахування місцевих інтересів і цінностей, ніж національні уряди. Наприклад, Джон Мак Кормік висловлюється вельми радикально: «Як ми можемо взагалі думати або формувати думку про те, чого ми не знаємо» [5].

Побудована в 1950-х роках, міжнародна організація бореться з економічною кризою, націоналізмом, ворожістю між державами, агресією, конфліктами з економічною конкуренцією, але на даний момент це схоже на боротьбу з новими типами симптомів. 3 часом подібно європейським, так звана євродепресія, відмова від інституційних рішень Європейського Союзу та осіб, які приймають рішення, тощо - стають дедалі актуальними питаннями.

Відзначимо, що Хартія основних прав $\Theta_{\text {в- }}$ ропейського Союзу визначає: гідність, свободу, рівність, солідарність, права громадян, справедливість, більше того, держави пов'язані цими пунктами. Однак на сьогодні повага до перерахованих цінностей здається сумнівною [1].

Проблеми, пов'язані з долею Союзу, також вийшли на перший план у населення держав-членів. Так, весною 2010 року більшість демонструвала, хто не голосує за майбутнє спільної Європи. Більше того, результати дослідження Євробарометра 2004 року показали, що більшість громадян $Є С$ байдужі до можливості провалу. Цей показник не міг бути записаний на рахунки економічної кризи того року. Тому суть проблеми набагато глибший [3, с. 10].

У державах-членах ця недовіра також виникає у їхніх діях, які не беруться до уваги громадою, не зважаючи на власні національні інтереси. Розрив між західними і східними країнами не потрібно пояснювати, оскільки в історії існують відмінності в розвитку і у менталітеті, в результаті трансформації, розколів церков, здійснення географічних відкриттів і 
промислових революцій. Але протилежність скандинавських країн і південно-європейських країн $\epsilon$ новизною щодо протилежною [1].

Якщо євро-скептицизм і націоналістичні висловлювання продовжують виникати, то найменший конфлікт може стати нафтовою пожежею, і держави-члени можуть опинитися на другорядних ролях на тлі зростаючих держав Америки та Азії.

Ідентичність $\epsilon$ ключем до збереження

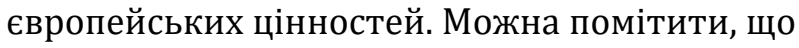
в контексті політичних або економічних цілей робиться маніпуляційна спроба визначити особистість. Ідентичність, мабуть, єдиний фактор, який може створити почуття приналежності та почуття відповідальності з боку громадян. Включає ностальгію за спільне минуле, поточну солідарність і толерантність, інтерес до спільного мирного майбутнього [3, c. 7].

Економіка Леопольда Кора свідчить про те, що великі розміри держав погані для економіки та суспільства. «Малі держави, малі країни та малі економіки є більш мирними, продуктивними та творчими, ніж наддержави. Вони б займалися глобальними проблемами не 3 подальшою глобалізацією, з більшим розривом; вони не вірить у велике, але у багато дрібних одиниць. Вони виявили, що в такому поділі Європи, шанси на війни і виникнення конфліктів будуть набагато меншими, оскільки лідери малих держав будуть більш відповідальними за інтереси власного народу і будуть більш гнучкими у міжнародних відносинах [4].

Поглиблюється європейська криза і деякі держави-члени мають суперечливі погляди на єдність, рішення та необхідні напрямки інтеграції. Найбільш радикальний шлях, очевидно, був обраний англійцями, коли вони вирішили провести референдум. Іншим питанням, звичайно, $\epsilon$ те, наскільки враховані фактичні наслідки Brexit. 3 тих пір відбувалися численні переговори між прем'єрміністром Великої Британії Терезою Мей і $€ С$ про вихід. Офіційно призначена дата виходу 29 березня 2019 року, втім, це проблематичне питання, як про це свідчить реальність. На сьогодні питання виникає наступне, чи розроблять плани подальшої співпраці і досяг- нуть компромісу з Європейським Союзом. Маргарита Шкінас, голова прес-служби Європейської комісії, відповіла на питання про вихід країни-члена: «Не шукайте відповідей у Брюсселі, тепер Лондон має розкрити карти, а не ми» [9].

Але яка позиція Європейського Союзу щодо Brexit? Той факт, що він не зіткнувся 3 такою ситуацією в минулому, полягав у тому, що держава-член саме добровільно заявила про свій намір виходу з ЄС. Це був складний час для лідерів $€ C$ і чиновників у поточний кризовий період.

Згідно думки прем'єр-міністра Угорщини Віктора Орбана, ЄС більше не є реальністю, оскільки він ще не дозволив здійснити мрію Європейського Союзу. Він вважає, що Союз повинен дозволити країнам вільно діяти у власній політиці і таким чином утворити спільний альянс у Європі. Позиція канцлера $\mathrm{Hi}-$ меччини Ангели Меркель різко контрастує. Вона вважає помилкою повернення до національної політики. Вона підкреслює, що Європа не вийшла за межі свого поділу та історії. Це цікава думка представника держави, що мала дві війни, і досі «несе» труднощі інтеграції.

Можливо, на сьогодні найбільш розбіжним питанням $\epsilon$ належне управління масовою міграцією. 3 самої негативної точки зору бачить міграцію прем'єр-міністр Угорщини Віктор Орбан, яку він називає реалістичною. Його уряд відкрито виступає проти міграції, хоче уникнути ослаблення національних мов і розмивання кордонів. За словами прем'єрміністра, за введеною квотою $є$ складний план, який є трампліном для втрати Європи та самої християнської культури. Канцлер Німеччини Ангела Меркель підкреслює важливість свободи пересування, що є основною умовою спільного європейського ринку. Вона вважає, що Європейський Союз не може діяти без прозорості, відкритості кордонів, і що це має стосуватися зовнішніх кордонів Європи, i необхідно розробити політику солідарності в цьому відношенні. Прем'єр-міністр Франції Еммануель Макрон вважає, що це не національне питання притулку, а загальний європейський політичний виклик. Приєднання до німецької позиції передбачає спільну охорону кордонів, єдину політику щодо Африки та 
юридичних процедур з міграції включно [6].

На сьогодні лідери двох останніх країн працюють у тісній співпраці. Угода, підписана 22 січня 2019 року, також включає історичне примирення між Німеччиною та Францією: «Договір Аахена - це економічна політика, зовнішня політика та політика безпеки, освіта, культура, дослідження та технології, клімат та охорона навколишнього середовища, що зміцнить зв'язки між Німеччиною та Францією у сфері транскордонної та співпраці громадянського суспільства» [8].

Згідно думки прем'єр-міністра Італії Джузеппе Конте, більша солідарність може відновити єдність Європи і зміцнити спільну європейську свідомість. У своєму виступі 2019 року Конте висловив сумніви в тому, що держави-члени дійсно борються за спільне бачення, адже тільки основоположні договори та сучасні договори утримують Європейський Союз разом. У своєму виступі він говорить про прояви, орієнтовані на людину: «Вільне переміщення людей важливіше, ніж потоки капіталу, це один з найбільших успіхів для європейської спільноти». I продовжує, що найважливішою цінністю для молодих європейців була свобода, за яку боролися їхні предки під час двох світових воєн» [2].

Крім того, він вважає утопію ідентичність людей, які називають себе європейцями. Він вважає, що $Є С$ втратив інтерес своїх громадян, і сьогодні це, здається, лише є економічна і торговельна організація в їхніх очах, що значно послаблює близькість людей, збільшує неписьменність, недовіру і розчарування. Це має змінитися в майбутньому, наблизити лідерів та громадян: «Європейський на- род все частіше закликає нас дослухатися до їхніх думок» [2].

Узагальнюючи, можливо зробити наступні висновки. Можливо, питання майбутнього Європейського Союзу сьогодні більш ніж коли-небудь сумнівне. Це не просто вибір майбутньої форми інтеграційних зв'язків, а сама концепція європейства стала центром дискусії. Чи представляють традиційні, національно-християнські цінності Європу, або ж основні людські ідеали є основою ідентичності континенту? Чи існує реальне протиріччя між цими двома?

Якщо Європа дійсно бореться за збереження і зміцнення міжнародного співробітництва, вона повинна спрямовувати свою діяльність на шляхи вирішення глобальних проблем (екологічна ситуація, забруднення, викликане зміною клімату, нелегальна міграція, тероризм тощо). Однак, це неможливо здійснити без узгоджених дій держав-членів, які на даний момент здаються немислимими. Консервативні традиційні цінності Європи виступають проти лібералізму Заходу. На додаток до економічних інтересів, батьки-засновники хотіли створити єдність націй, сильний блок, який захищає себе від викликів та проти інших континентів. Але що $\epsilon$ європейське? Загальний мотив, який пов'язує ці держави з різними думками, переконаннями та різними національностями. Це моральні цінності, які розвивалися протягом тисячоліть. Сьогодні очевидно, що Європа може повернутися на стадію компромісу у єдності і вирішити ії найгостріші проблеми. Перспективи подальших досліджень вважаємо здійснити щодо майбутнього розвитку окремих країн-членів ЄС.

\section{Список використаних джерел}

1. Arató Krisztina, Koller Boglárka: Európa Utazása. Budapest: Gondolat 2015, - 3040.

2. Conte Giuseppe: Több szolidaritást! - Európa jövőjéről beszélt Conte, olasz miniszterelnök:https://mandiner.hu/cikk/20 190212_eur opa_jovojerol_beszel_conte_olasz_miniszterelnok?fbclid=IwAR33MpIs69F20YJxZxgfoCjY86cw8v3PowRxlaz 27yN MhQ4PSoCs8-9XhAo.

3. Engels David: A birodalommá válás útján. Az európai Unió válsága és a római köztársaság hanyatlása. Budapest: L’Harmattan, 2017. 7.o.

4. Fortuna Dorian: A kis államoké a jövő? https://foter.ro/cikk/20150205_hora_iu_pepine_a_kis_allamoke_a_jovo?=Iw AR0FwuHFBFKNQHMMJyN11_9fp1zZcBiSklb6mWV4PRG250DM10KYKy4bB24.

5. Gyurgyák János: Európa alkonya? Budapest: Osiris, 2018. 183.o.

6. MAGYARI Péter: Csütörtökön minden eddiginél világosabb lett, hogy mennyire mást gondol a jövőről Orbán, Merkel és Macron: https://444.hu/2018/05/12/csutortokon-minden-eddiginel-vilagosabb-lett-hogy-mennyire-mast-gondol-a-jovorol-orban-esmerkel-es-macron?fbclid=IwAR28KcQgK5IaAHLGRpFj0ft80R1QkZl-spAHhwtxTVBUzkaguCmJZEvV2os.

7. $\quad$ Ortega Jose y Gasset: Elmélkedések Európáról. Budapest: L'Harmattan, 2007.

8. Új német és francia megállapodási szerződést ír alá Merkel és Macron:https://mandiner.hu/cikk/2019 0108_uj_ne met_fra nci a_egyuttmukodesi_megallapodast_ir_ala_merkel_es_macron?fbclid= IwAR00CpdZ LqFYfBmM5h huwYMGtuSQm II_V1 8reLYYW_uVHuvSxwJmze0dUY. 
9. Vegyünk még egy nagy levegőt a brexit előtt:https://index.hu/kulfold/2019/01/22/theresa_may_nagy_britannia_brexi tegyesult_kiralysag_eu_kilepes_maradas/.

\section{References}

1. Arató Krisztina, Koller Boglárka: Európa Utazása. Budapest: Gondolat 2015, - 3040.

2. Conte Giuseppe: Több szolidaritást! - Európa jövőjéről beszélt Conte, olasz miniszterelnök:https://mandiner.hu/ cikk/20190212_europa_jovojerol_beszel_conte_olasz_miniszterelnok?fbclid=IwAR33MpIs69F20YJxZxgfoCjY86cw8v3Pow Rxlaz27yNMhQ4PSoCs8-9XhAo.

3. Engels David: A birodalommá válás útján. Az európai Unió válsága és a római köztársaság hanyatlása. Budapest: L’Harmattan, 2017. 7.o.

4. Fortuna Dorian: A kis államoké a jövő? https://foter.ro/cikk/20150205_hora_iu_pepine_a_kis_allamoke_a_jovo?=Iw AR0FwuHFBFKNQHMMJyN11_9fp1zZcBiSklb6mWV4PRG250DMl0KYKy4bB24.

5. Gyurgyák János: Európa alkonya? Budapest: Osiris, 2018. 183.o.

6. MAGYARI Péter: Csütörtökön minden eddiginél világosabb lett, hogy mennyire mást gondol a jövőről Orbán, Merkel és Macron: https://444.hu/2018/05/12/csutortokon-minden-eddiginel-vilagosabb-lett-hogy-mennyire-mast-gondol-a-jovorol-or ban-es-merkel-es-macron?fbclid=IwAR28KcQgK5IaAHLGRpFj0ft80R1QkZl-spAHhwtxTVBUzkaguCmJZEvV2os.

7. Ortega Jose y Gasset: Elmélkedések Európáról. Budapest: L'Harmattan, 2007.

8. Új német és francia megállapodási szerződést ír alá Merkel és Macron:https://mandiner.hu/cikk/20190 108_uj_nemet _francia_egyuttmukodesi_megallapodast_ir_ala_merkel_es_macron?fbclid=IwAR00CpdZLqFYfBmM5hhuwYMGtuSQmII_ V1_8reLYYW_uVHuvSxwJmze0dUY.

9. Vegyünk még egy nagy levegőt a brexit előtt:https://index.hu/kulfold/2019/01/22/theresa_may_nagy_britan nia_brexi tegyesult_kiralysag_eu_kilepes_maradas/.

\section{Киш Ева, Дограй Жофиа. Перспективи будущего развития Европейского Союза}

На сегодня актуальной проблемой европейской системы международных отношений есть будуще развитие Европейского Союза. Европейский Союз прошел сложный путь развития. Все більше ы більше идей существует относительно вопросов будущего развития Европейского Союза, прежде всего как «единства в разнообразии», что именно сегодня также является дискусионным. Даной теме исследования приделяется все більше внимания как со стороны експертов, политологов и международников, так и граждан европейского континента. Проблемные вопросы, ето - глобализация, экономика, миграция, внутренние реформы и другие.

Ключевые слова: Европейский Союз, интеграция, идентичность, миграция, сотрудничество.

\section{Kish Yeva, Dorgay Z.The European Union future development perspectives}

Today, more and more people are raising the question of the future of the European Union, and often the expression of "unity in diversity” seems to be breaking. The topic is being given more attention: more attention is not given to political scientists and international experts. Perhaps the question of the future of the European Union is more than ever questionable today. It is not justthe choice of the future form of integrationties, but the concept of Europeanity itself has become the focus of debate. Do traditional, nationalChristian values represent Europe, or should general human ideals be the basis of the continent's identity? Is there any real contradiction between the two, or are the daily political struggles digging into the trenches?

If Europe really struggles to maintain and strengthen international engagement, its hould directits activities to ways of solving global problems. (ecological situation, illegal migration, terrorism, etc.) However, this is not possible with out coordinat daction by the Member States, which at the moment seem sunimaginable. In addition to the economic interests, the founding fathers wanted to create a unity of nations, a strong blockthat protectst hemselves againste a chother's challenges against the other continents. It has been clearly seen that in the eyes of a super power, such ast he United States of America, the countries of Europe alone are onlygrains of sand. It would be the most pressing task if the EU were to be closer to eachotherifit were to maintain it sown culture, economy and population by all means. This could make Europe more attractive both in the world and in the eyes of its own citizens.

The approaches to the analysis of geopolitical situation in the Central European Region and geopolitical role of the borders of the Central European Countries are principally new. The main theoretical and methodological grounds of the study of borders, particularly in the context of investigating of causes and consequences of transformation of the new eastern border of the EU, are analyzed in the article.

Today's organization, knownas the European Union, has undergone a long history and political process for joining forces. Our common European culture has evolved for centuries and inherited the heritage of different peoples.

Key words: European Union, integration, identity, migration, cooperation. 
DOI: 10.33310/2519-2809-2019-47-1-57-62

УДК 94(4) «0375/1492»:327

\author{
ВоЛОДИМИР КУЗОВКОВ \\ кандидат історичних наук, доцент кафедри історії та археології \\ Миколаївського національного університету імені В. О. Сухомлинського, \\ м.Миколаїв, Україна \\ e-mail: kusovkov@ukr.net
}

\title{
ВІЗАНТІЙСЬКА ДИПЛОМАТІЯ У ТВОРАХ КОНСТАНТИНА VII БАГРЯНОРОДНОГО
}

\begin{abstract}
Міжнародні відносини у ранньому середньовіччі є однією з наукових проблем, які актуальні сьогодні для історичних досліджень. Важливими джерелами з історії міжнародних відносин середини X cm. є трактати візантійського імператора Константина VII Багрянородного. В статье анализируются свидетельства этих трактатов о внешней политике Византии. Автор сравнивает их с материалами других работ императора, включая раздел «Исторических эксцерптов» - «О посольствах». Особое внимание уделяется свидетельствам, которые характеризуют отношения Византии с Аббасидским халифатом и зависимыми от него государствами - эмиратами.

Ключевые слова: византийская дипломатия, «Об управлении империей», «О церемониях», Константин VII Багрянородный, внешняя политика Византии, международные отношения.
\end{abstract}

В історії дипломатії середньовічної Європи Візантійська імперія займає особливе місце. Залишаючись спадкоємицею стародавнього Рима, вона зберігала його традиції і візантійські посли могли користуватись багатою античною цивілізаційною спадщиною у галузі міжнародних відносин. Значною віхою в історії візантійської і європейської дипломатії стала доба імператора Константина VII Багрянородного (913-959рр.), що знайшла відображення в його наукових працях. Найбільш важливе місце у літературній спадщині імператора за рівнем і кількістю свідчень о міжнародних відносинах займають трактати «Про церемонії» та «Про управління імперією» [3; 8]. За змістом і стилем подання матеріалу ці твори можна вважати одними з характерних літературних пам'яток доби «візантійського енциклопедизму», яка припадає на часи правління Македонської династії (867-1056) [1, с. 94-95].

Матеріали обох трактатів неодноразово викликали зацікавленість багатьох дослідників. У різні часи вагомий вклад у дослідження літературної спадщини Константина VII Багрянородного внесли Дж. Бьюрі, В. В. Латишев, Ф. Дюльгер, Р. Дженкінз, Г. Острогорський, А. Тойнбі, Д. Оболенський, Г. Г. Літаврін та інші $[1,6,9,11]$. В останні роки інтерес до імператорських трактатів не спадає, а по відношенню до «Про церемонії» навіть зростає. Підтвердженням останньої тенденції $є$ дослідження П. В. Кузенкова та О. М. Лугового $[4,5]$. Аналіз досліджень дозволяє зробити висновок о необхідності приділити увагу порівняльному аналізу ключових трактатів Константина VII Багрянородного, їх функціональному призначенню та окремим аспектам інформації, що не знайшли достатнього висвітлення у попередніх працях.

У чому ж полягає цінність свідчень з історії дипломатії, що збереглись у творах імператора Константина VII? Трактат «Про церемонії» уявляє собою довідник внутрішнього розпорядку життя візантійського двору. У ньому надаються інструкції щодо проведення політичних і релігійних заходів у палаці за участю імператора і придворних. Окремі глави (84-95 I книги, 46-48 II книги) торкаються дипломатичних відносин, зокрема опису особливостей протоколів прийому іноземних посланців і листування з правителями інших держав.

Інформацію трактату «Про церемонії» суттєво доповнює інший твір Константина VII - «Про управління імперією» - адресоване його сину і наступнику, майбутньому імператору Роману II (959-963). Цей твір 
писався, як підручник з управління i, можливо, $є$ першим твором цього жанру у Європі, що дійшов до нашого часу. У трактаті «Про управління імперією» даються практичні поради щодо лінії поведінки, якої треба дотримуватись у відносинах з різними сусідніми державами. Отже, обидва твори носили характер «документів для внутрішнього використання» і не розраховувались для читання широкою аудиторією [10, р. 33-38].

Тексти обох трактатів мають писались тривалий час і містять декілька шарів інформації. Так, протокол прийому болгарських послів приводить різні титули болгарського правителя, які відображають зміни, що відбулись у політичному статусі його держави протягом I половини X ст.

Значну роль в обох трактатах відіграє звернення до історичних даних, які передають досвід відносин з сусідами вироблений 3 часів Пізньої Римської імперії. У I книзі трактату «Про церемонії» (глави 84-95) використовуються уривки з твору Петра Патрікія, відомого дипломата доби Юстиніана I (527-565) про відносини з державами Сасанідів та остготів [8, p. 396, 398-409].

Історичні екскурси в трактаті «Про управління імперією» набагато інформативніші. Константин VII вважає за потрібне надати своєму наступнику свідчення про походження народів, з якими сусідить імперія, задля того, щоб сформувати у нього уявлення про традиції міжнародних відносин різних регіонів. Глави (14К22), присвячені мусульманському світу, надають інформацію про відносини Візантії та халіфатом з часів правління «праведних» халіфів (632-661) [3, с. 64-87]. Подібні історичні екскурси ми зустрічаємо і в розділах присвячених Венеції, Далмації, Хорватії, Сербії, мадярам («турки» у трактатах) тощо [3, с. 106-149, 158-163].

Слід відмітити, що зацікавленість історі$є ю$ міжнародних відносин попередніх епох $\epsilon$ відмінною рисою багатьох творів, що належать до літературної спадщини Константина VII. Так, своєрідним довідником з історії дипломатії можна вважати розділ «Про посольства» (або «Про римський посланців до народів»), який входив до збірки екцерптів (виписок) з творів античної літератури, скла- деної за дорученням імператора. Близько половини матеріалу цього розділу взяті з праць пізньоримських істориків IV-VI ст. Такі з них, як «Історія війн Юстиниана» Прокопія, «Нова історія» Зосими та «Історія» Феофілакта Симокатти, дійшли до наших часів повністю. Значна частина творів інших пізньоримських та ранньовізантійських авторів (Петр Патрикій, Іоанн Антиохійський, Пріск Панійський, Малх Філадельфійський, Менандр Протіктор) збереглась саме у цій збірки у вигляді наведених виписок [2, с. X-XI].

Показово, що троє з вищезгаданих авторів мали значний власний досвід дипломатичної діяльності. Прокопій служив секретарем відомого полководця Велізарія, Пріск приймав участь у посольстві до ставки Аттіли (448р.), а Петр Патрикій у 562 р. укладав від імені імперії угоду з Іраном.

Розділ «Про посольства» вважався Константином VII однією з важливіших частин його літературного компендіуму. Це відмічав сам імператор у передмові до нього, яка містила ще окремий параграф «Правила, як приймати іноземних посланців і як відправляти посольства». Тут надавались поради щодо поведінки з іноземними послами залежно від відстані їх держави та її моці [2, XI-XIII].

Теоретичний матеріал розділу «Про посольство» скоріш за все став плодом наукової діяльності Константина VII до початку його самостійного правління у 945 р.. 3 трактатами «Про управління імперією» та «Про церемонії» його поєднує належність до однієї наукової сфери. Матеріал розділу «Про посольства» свідчить про рівень обізнаності самого Константина VII у теоретичних засадах дипломатії та міжнародних відносин до початку його самостійної політичної діяльності. Трактати «Про управління імперією» та «Про церемонії» були складені протягом самостійного правління Константина VII, тобто після 945 р.: перший з них - між 948 та 952 р., а другий - до 959 р., з пізнішою редакцією доби правління Никифора II Фоки (963-969) [3, с. 5; 9, p. 595-597]. У трактатах «Про управління імперією» та «Про церемонії» імператор звертається до вузькій аудиторії, якій намагається надати інформацію про сучасний стан справ і історія тут грає більш 
вторинну роль. Тільки матеріали Петра Патрикія увійшли до розділу «Про посольства» та у трактат «Про церемонії». Матеріали праць інших авторів не знайшли використання у пізніх трактатах імператора. Хоча в історичних екскурсах зустрічаються посилання інші твори, наприклад на «Хронографію» Феофана (гл. 22 «Про управління імперією») [3, c. 80-87].

Трактат «Про церемонії» надає нам офіційну точку зору візантійської дипломатії стосовно політичної ваги міжнародних партнерів імперії доби Константина VII. Глава 46 II книги надає інформацію про титули, що можна використати по відношенню до іноземних правителів. Загальна чисельність титулів складає 72, однак частина їх носить архаїчний характер (династ, ефор, герусіос) і трактат не містить згадок про їх застосування на практиці [8, p. 679].

47 глава повідомляє про особливості офіційного прийому іноземних послів: формули привітання з боку іноземних послів та відповіді на це логофета, який веде прийом. Конкретні формули приводяться для послів папи римського, правителя Болгарії, багдадського халіфа та емірів Тарсу, Єгипту, Персії і Хорасану [8, p. 680-686]. Думається, що вибір правителів для цього переліку зумовлений особливою важливістю для імперії контактів з ними. Папа римський вважався «духовним отцем» імператора. Дунайська Болгарія безпосередньо сусідила з імперією на Балканах і мала можливість погрожувати самому Константинополю, що неодноразово відбувалось у часи правління хана Крума та царя Симеона. Глава містить зміни у протоколі прийому болгарських послів, які показують поступове зростання їх політичного статусу в очах візантійських дипломатів.

Формула прийому послів абасидських халіфів враховує їх прибуття до Константинополю разом з послами емірів Тарса - одного 3 васалів Багдаду. 3 середини IX ст. тарсійські еміри стримували візантійський наступ на південному сході Малої Азії, а з землями, які входили до самого «домену» багдадських халіфів, Візантія безпосередньо не мала спільного кордону.

Торкаючись прийому послів наймогутніших васалів багдадських халіфів - емірів
Египту (можливо, Іхшидідів), Персії (можливо, Буїди) та Хорасану (можливо, Саманідів), автор трактату «Про церемонії» приводить декілька варіантів, актуальність яких може залежати від політичної ситуації [8, p. 684-686]. Перший варіант застосовується у випадку васального підпорядкування цих еміратів Візантії. У цьому випадку еміри устами своїх послів позиціонують себе, як ті, що «підпорядковуються царству ромеїв і надсилають пакт», а також, як «найвірніші раби вашої імперії». Окремо у трактаті згадується про протоколи прийому послів цих емірів у випадках проголошення ними власної незалежності, або визнання ними зверхності Багдаду, однак опис процедури у цих випадках відсутній.

Думається, що подібний підхід автора трактату по відношенню до статусу емірів не випадковий i продиктований політичною ситуацією, що склалась у мусульманському світі до середини X ст. Багдадський халіфат під владою династії Аббасидів переживав період політичного занепаду та розпаду. Ці процеси розпочались ще тоді, коли у 756 р. фактично незалежним від Багдаду став Кордовський емірат, і посилювались протягом IX ст. Після недовгої стабілізації на межі IX-X ст., ослаблення халіфату стає незворотнім в правління ал-Муктадіра (908-932). Реальна влада цього халіфа обмежувалась впливом, наближених до нього осіб і вдалих полководців, таких, наприклад, як євнух Муніс. Саме за алМуктадіра Аббасиди втрачають монополію на халіфську владу. У ці часи засновуються халіфати, альтернативні Багдадському, - 3 претензіями на універсальну владу в Тунісі виступили Фатіміди (910р.), а у мусульманській Іспанії - Омейяди (929р.). Еміри окремих областей, які офіційно розглядались у Багдаді, як губернатори, стають напівнезалежними правителями. У 945 р., коли Константин VII Багрянородний повернув собі реальну владу у Константинополі, шиїтські війська Буїдів (можливі еміри Персії у трактаті) оволоділи Багдадом, перетворивши Аббасидів на політичних маріонеток.

Занепад політичної влади Аббасидів надавав нових можливостей для дій візантійської дипломатії. Контакти Візантії з Єгиптом в обхід Багдаду частішають 3 приходом до 
влади еміра Мухаммеда ібн Тугджа (933р.). Імператор Роман I Лакапін (921-944) вів 3 ним переговори, про що свідчить лист, складений Феодором Дафнопатом. Лист свідчить про бажання Мухаммада стати «другом нашої величності» (тобто Романа I), йому пропонують визнати зверхність візантійського імператора в обмін отримання титулу архонт архонтів. Єгипетського еміра запрошували до Константинополя, де йому обіцяли пишний прийом та надання почесних титулів патрикія, анфіпата та стратига та можливість очолити одну з фем [5, с. 184]. Титул архонта архонтів («цар царів») міг підняти дипломатичний статус єгипетського еміра до рівня вірменського царя. Візантійсько-єгипетські відносини не призвели до виникнення союзу між державами, хоча знайшли відображення у згадці про особливо цінну за вартістю золоту печатку (18 екзагіїв), що прикладалась імператорською канцелярією до листа, якій направлявся єгипетському еміру.

Згадування послів від емірів Персії та Хорасану ставить питання про їх ідентифікацію. Ними могли бути Буїди (як еміри Персії) та Саманіди (як еміри Хорасана). Однак у наступній главі (48), у якій наводяться вступні формули до листів, що відправлялись до іноземних правителів, еміри Персії та Хорасана не згадуються. У трактаті «Про управління імперією» Персія і Хорасан часто ототожнюються, а у зв'язку з подіями середини X ст. повідомляється про незалежність їх правителя і прийняття ним титулу халіфа: «Не настільки давно, однак, коли амермумн Багдаду знов став слабким, опинився незалежними емір Персії, тобто Хорасану. Він проголосив себе самого амермумном, повісив коран на табличках на свою шию, подібно намисту. Він запевняє, що сам походить від роду Аліма» [3, с. 96-97]. Ця інформація трактату трактувалась коментаторами, як згадка про емірат Саманідів. Однак останні залишались сунітами і не відносили себе до нащадків Алі («Аліма»). Можна припустити, що у цьому випадку ми маємо згадку про захоплення влади над Багдадом дейлемітськими емірами Буїдами, шиїтами-імамітами. Однак ця емірська родина не присвоювала титулу халіфа. Ї̈ представник Ахмед ібн Бувайх у 946 р. отри- мав від Аббасида ал-Мустакфі титул амір алумара (емір над емірами), що символізувало передання повноважень головнокомандуючого, керівника військової адміністрації, а халіфа перетворювало на буїдську маріонетку.

Одним з продуктивних підходів щодо використання спадщини Константина VII при дослідженні міжнародних відносин X ст. може бути системний. Так, Д. Оболенський пропонував виділяти «Візантійську співдружність націй» - умовний симбіоз Візантійської імперії та держав, споріднених з нею політично, релігійно і культурно [6]. Подібне бачення тісних стосунків між імперією та їі сусідами відповідає сучасному баченню міжнародної системи [7]. При більш широкому погляді політичні міждержавні відносини у Європі та Азії, ми можемо уявити їх у вигляді системи, частиною якої була Візантія. Своєрідний перелік елементів (акторів) ранньосередньовічної системи міжнародних відносин наводиться у 48-й главі II книги трактата «Про церемонії» у вигляді вступних частин листів, які відправляв візантійський імператор, з титулами адресатів (акторів). Учасники міжнародних відносин (елементи системи, актори), згідно трактату не тільки світські правителі, але й духовні владики (римський папа, патріархи).

Характер елементів відрізняє міжнародну систему, описану Константином VII, від Вестфальської, яку у класичній парадигмі теорії міжнародних відносин вважали першої 3 існуючих. Вестфальська система поставила національну державу на місце основного актора міжнародних відносин [6, р. 256-265], коло ж учасників подібної системи у ранньому середньовіччі не було настільки однорідним. Ранньосередньовічна система характеризувалась ієрархією учасників, яка, згідно, наприклад, трактату «Про церемонії», відображалась у титулах адресатів листів візантійських імператорів і вартості золотої печатки, якою скріплювались ці листи.

Іншою важливою ознакою системи можна вважати розпорошення суверенітету між різними рівнями міжнародної ієрархії. Серед адресатів візантійського імператора ми зустрічаємо таких, хто отримував листинакази, тобто визнавали формальну зверхність Константинополя. Загальна кількість 
таких партнерів (акторів) в трактаті складає 38. Більшість серед адресатів складають правителі держав Балканського півострова, Кавказького регіону та Італії.

Важливою характеристикою міжнародних відносин раннього середньовіччя $\epsilon$ наявність держав, правителі яких претендували на універсальну владу. До таких правителів належав і візантійський імператор. Так, Константин VII, повчаючи свого сина Романа II, стверджував, що він, як імператор, повинен «піклуватись про спасіння усіх і правити і керувати світовим кораблем» [3, с. 36-37]. Протягом століть претензії правителів Константинополя стикались 3 схожими концепціями універсальної влади з боку арабських халіфів та франкських імператорів. Однак у I половині - середині X ст. конкуренти Візантії переживали складні часи і в цьому полягає унікальність міжнародного становища імперії за часи правління Константина VII Багрянородного (913-959).
Таким чином, наукова спадщина Константина VII Багрянородного містить унікальні свідчення про візантійську дипломатію не тільки часів правління самого імператора, але й надає ознайомитись 3 творами пізньоримських авторів, що не дійшли до наших часів у повному вигляді. Центральне місце серед трактатів імператора займають два твори - «Про церемонії» та «Про управління імперією». Вони виступають не тільки джерелами з історії міжнародних відносин, але й дозволяють розкрити спосіб мислення візантійських дипломатів та механізми прийняття політичних рішень. Погляди імператора, висловлені на їх сторінках $\epsilon$ наслідком багаторічного вивчення середовища дій дипломата, відображення чого став розділ «Про посольства», який став частиною константинівського літературного збірника. Відносини між державами і народами зображені у трактатах Константина VII Багрянородного мають вигляд міжнародної системи, організованої у вигляді багаторівневої ієрархії.

\section{Список використаних джерел:}

1. Бибиков М. В. Историческая литература Византии. СПб: Алетейя, 1998. 318 с.

2. Византийские историки Дексипп, Эвнапий, Олимпиодор, Малх, Петр Патрикий, Менандр, Кандид, Ноннос и Феофан Византиец. Пер. с греч. С. Дестуниса; примеч. Г. Дестуниса. СПб.: Типография Л. Демиса, 1860. 495 с.

3. Константин Багрянородный. Об управлении империей. М.: Наука, 1989. 496 с.

4. Кузенков П. В. Реальная политика или великодержавная идеология? Византийская дипломатия X в. по данным трактатов // История : дар и долг. Юбилейный сборник в честь Александра Васильевича Назаренко. М.; СПб., 2010. С. 73-99.

5. Луговой 0. М. Политическая карта мира глазами византийского интеллектуала X века // Византийская мозаика: Сборник публичных лекций Эллино-византийского лектория при Свято-Пантелеимоновском храме / Ред. проф. С. Б. Сорочан; сост. А. Н. Домановский. Выпуск 6. Харьков: Майдан, 2018. С. 159-190.

6. Оболенский Д. Византийское Содружество Наций. Шесть византийских портретов. М.: Янус-К., 1998. 655c.

7. Buzan B., Little R. International Systems in World History : Remaking the Study of International Relations / Barry Buzan, Richard Little. New-York: Oxford University Press, 2000. 472 p.

8. Constantine Porfirogenito. De ceremoniis aulae byzantinae libri II/ Constantine Porfirogenito. Bonnae, 1828. $807 \mathrm{~s}$.

9. Kazhdan, A. The Oxford dictionary of Byzantium. Oxford: Oxford University press, 1993.2232 p.

10. Stephenson P. Byzantium's Balkan frontier: A Political Study of the Northern Balkans, 900 - 1204/ P.Stephenson. Cambridge: Cambridge University Press, 2004. 352 c.

11. Toynbee A. Constantine Porphyrohenitus and his world / Arnold Toynbee. London: Oxford University Press, 1973.768 p.

\section{References}

1. Bibikov, M. V. (1998). Istoricheskaia literatura Vizantii. SPb: Aletheia.

2. Buzan, B., Little, R. (2000) International Systems in World History : Remaking the Study of International Relations. New-York: Oxford University Press.

3. Constantine Porfirogenito. (1828) De ceremoniis aulae byzantinae libri II. Bonnae.

4. Destunis, S. (1860) Vizantiiskie istoriki Deksipp, Evnapii, Olimpiodor, Malkh, Petr Patrikii, Menandr, Kandid, Nonnos i Feofan Vizantiets. SPb: Publishing L. Demis.

5. Kazhdan, A. ed. (1993) The Oxford dictionary of Byzantium. Oxford: Oxford University press.

6. Konstantin Bagrianorodnyi. (1989) Ob upravlenii imperiei. M.: Nauka.

7. Kuzenkov, P. V. (2010) "Realnaia politika ili velikoderzhavnaia ideologiia Vizantiiskaia diplomatiia X veke; po dannym traktatov", Istoriia: dar i dolg. IUbileinyi sbornik v chest Aleksandra Vasilevicha Nazarenko, pp. 73 - 99.

8. Lugovoi 0. M. (2018) "Politicheskaia karta mira glazami vizantiiskogo intellektuala X veka", Vizantiiskaia mozaika: Sbornik publichnykh lektsii Ellino-vizantiiskogo lektoriia pri Sviato-Panteleimonovskom khrame, 6, pp. 159-190.

9. Obolensky D. (1998) Vizantiiskoe Sodruzhestvo Natsii: Shest vizantiiskikh portretov. M.: Ianus-K.

10. Stephenson, P. (2004) Byzantium's Balkan frontier: A Political Study of the Northern Balkans, 900 - 1204. Cambridge: Cambridge University Press.

11. Toynbee, A. (1973) Constantine Porphyrohenitus and his world. London: Oxford University Press. 
Кузовков В. Византийская дипломатия в сочинениях Константина VII Багрянородного

Международные отношения в раннем средневековье являются одной из научных проблем, которые актуальны для научных исследований. Важными источниками о международных отношениях середины X в. являются трактаты византийского императора Константина VII Багрянородного. В статье анализируются свидетельства этих трактатов о внешней политике Византии. Автор сравнивает их с материалами других работ императора, включая раздел «Исторических эксцерптов» - «О посольствах». Особое внимание уделяется свидетельствам, которые характеризуют отношения Византии с Аббасидским халифатом и зависимыми от него государствами - эмиратами.

Ключевые слова: византийская дипломатия, "Об управлении империей», «О церемониях», Константин VII Багрянородный, внешняя политика Византии, международные отношения.

\section{Kuzovkov V. Byzantine diplomacy in the works of Constantine VII Porphyrogenitus}

International relations of Early Medieval Ages are one of many science's issues that require further examination. Important sources about international relations mid-X century are the works of Eastern Roman Emperor Constantine VII: "De administrando imperio" and "De cerimoniis aulae Byzantinae". There are analyzes evidences of these treatises about the foreign policy of Byzantium in article. Author compares them with others works of emperor, including chapter from "Excerpts from the histories" - "De legationibus"(On embassies).

Special attention is paid to the evidences that characterize relations Byzantium with Abbasid caliphate and its satellite states-emirates. The author notes the distinctive nature of relationship between Byzantine Empire and Egypt where the governors Ikhshidid dynasty ruled, who recognized power of the Bagdad's caliph formally.

In your treatises Constantine VII Porphyrogenitus mentions Islamic ruler, who known as "emir of Persia and Khorasan". These evidences suggest that they are members of Buyid's dynasty. In 945 The Buyid's forces taken Bagdad and conquered Iraq. Al-Muktafi, the Abbasid caliph became his vassal.

Analyze international systems is one of the key approaches what can use for research international relations of Early Medieval Ages. D. Obolensky created the concept of Byzantine commonwealth that including Byzantium and its satellite states. According the treatise "De cerimoniis aulae Byzantinae" relationship Bizantine Empire with other states and nations were one of part the big international system that exists in Europe and Asia in Early Medieval Ages. Certain characteristics of this system were hierarchy and "diffusion" of sovereignty.

Keywords: byzantine diplomacy, De administrando imperio, De cerimoniis, Constantine VII Porphyrogenitus, foreign policy of Byzantium, international relations 


\author{
ОТТИЛА ЙОВЖА \\ аспірант Національного університету державної служби, \\ м. Будапешт, Угорщина.
}

\title{
НОВИЗНА В ОЦІНЦ ІСТОРИЧНОЇ ПОСТАТІ Д'ЄРДЯ ДОЖІ ДО 500-річчя СЕЛЯНСЬКОЇ ВІЙНИ
}

\begin{abstract}
В науковій статті вивчаємо нові підходи щодо вивчення історичною наукою постаті керівника селянської війни 1514 р. - Д'єрдя Довжі. причини, хід та придушення селянського повстання, а також зміни в історіографії оцінки селянської війни. Намагаємося дати нову трактовку цього історичного процесу, який, у свою чергу, став одним з передумов втрати незалежності Угорського королівства після 1526 р.

Ключові слова: селяни, повстання, страта, дворянство, Д'єрд Дожа.
\end{abstract}

«Переформатування» угорської селянської війни та особи Д'єрдя Дожі у зв'язку з 500річчям (2014 р.) початку повстання безумовно було своєчасним, оскільки протягом останнього століття його німб й історична роль були суттєво переоцінені. До 1991 р. ім'я Д'єрдя Дожі сприймалося суспільною думкою, як символ селянства, й через це і вивітрився звідти тому, що зникла потреба у революційних героях.

Історія селянської війни має велику джерельну базу та історіографію. Серед сучасників варто визначити істориків-церковників Д’єрдя Серемі [12], Антала Веранчича [14] та Іштвана Таурінуса [11], яки відверто висловлювали антиселянські думки. Хроністи Томаш Гелтаї [5] та Лайош Туберо [13] вже підхидили до оцінці подій помірково, наголошуючи на класових відмінностях. На початку XX ст. біографічні праці Шандора Маркі [7] та Вільмоша Фракної визвали жваву дискусію щодо оцінці постаті Д'єрдя Довжі та його селянського руху. На міжнародній науковий конференції в Сату-Маре (Румунія) 3 нагоди 500-ї річниці повстання історик літературної спадщини Бейла Помогач висновки підсумував так: «Інтерпретація постаті Д'єрдя Дожі та його війни, страшної смерті і політикоморальної спадщини, по суті, ніколи не була настільки однозначною, як інших, відомих героїв нашої історії. (...) велася полеміка і про оцінку його історичної ролі» [9]. Цю полеміку намагається підтвердити член Угорської Ака- демії Наук, історік Ігнац Ромшіч у статті «Секелі Д’єрдь Дожа. Бандит та/або народний ватажок?» [10]. Після короткого огляду історії селянської війни і життя Дєрдя Дожі, автор підсумовує пов'язані з темою, часто суперечливі враження сучасників, історичні інтерпретації, художні бачення та систематизує їх за період з XVI сторіччя до теперішній час в контексті спрощеної системи політики ідентичності. В своїй доповіді влітку 2014 року в м. Timișoara (Румунія) сам Ромшіч визнав, що якщо обмежитися фактами про Д’єрдя Дожу, його доклад триватиме лише 10-15 хвилин: «У історика існують труднощі з сучасністю у тому, що він багато чого знає і змушений вибирати. Наші знання про Д'єрдя Дожу і його сучасників, угорських лідерів і героїв XV-XVI сторіччя, навпаки, набагато бідніші» [10].

3 нагоди 500-річчя селянської війни історики дійшли згоди у тому, що у зв'язку з селянським повстанням Д'єрдя Дожі було знайдено відносно небагато нових матеріалів, більшість з яких вже були опрацьовані Шандором Маркі [7] й Анталом Фекете Надь [2]. У зв'язку 3 ювілеєм завдання дослідників було лише в тому, щоб зафарбувати ті «білі плями», якіх досі можна знайти в біографії Д'єрдя Дожі.

У підручниках з світової історії зазвичай згадується, що основною причиною селянської війни Д'єрдя Дожі було нелюдське пригноблення бідний верств населення Угорщини. Однак важливо зазначити, що ці причини трактуються не у відповідності до сучасного 
історичного мислення. Важливу роль відігравала релігійність широких верств населення, яка в антитурецькій кампанії була суттєвою опорою, адже ії учасники після смерті могли розраховувати на повне відпущення всіх грихів. Тим, що дворянство заборонила селянам брати участь в хрестових походах проти турків, практично перекрили єдиний шлях спасіння їх душ. Також слід розглядати як важливий мотив тогочасного «суспільного договору» наступне: звільнення від податків i привілеї шляхта завдячила тим, що захищала країну і націю ціною крові і життя. Якщо шляхта не виконає своїх зобов'язань, то втрачає свій привілейований статус, а її права, пов'язані $з$ ним, також переходять до селянства. Одним з важливих каталізаторів цього руху була гілка обсервантів чернечого ордену францисканців, яка успішно привила масам центральну ідею повстання - «святе військо» селян, виконує волю божу проти «невіруючої» шляхти, що заважає божественній місії. Підсумовуючи причини селянського повстання, можна сказати, що випадкові події міжнародної політики були так само важливі, як і внутрішні політичні інтригі політичної еліти та внутрішньо-політичні процеси Угорського королівства.

Що стосується життя самого Д'єрдя Дожі, то дата і місце його народження залишаються невизначеними, та навіть його справжне ім'я викликає сумнівив. За хронікою Міклоша Іштванфі поширена думка, що місцем народження Дожі $\epsilon$ село Далнок (комітат Гаромсек), або село Макфолво. Одне вірно - у сучасних джерелах він згадується як Д’єрдь Секелі (Georgius Zekel) - прізвище Дожа стало загальноприйнятим лише вслід за Міклошем Іштванфі. Дожа походив з благородної секельської сім'ї пріміпілусів (дрібних дворян), тому уява про селянське походження також $\epsilon$ хибною. Досі невідомо як він виглядав, адже не існує жодного сучасного зображення чи опису про нього, відомо лише те, що він був воїном сильної статури. Хоча про його життя ми знаємо порівняно мало (наявні документи передбачають існування аш двох Д’єрдьів Секелі/Дожа), тим більше відомо про його смерть. Згідно зі загальноприйнятою версією Д’єрдя Дожу було страчено панами, на чолі 3 трансільванським воєводою Яношем Сапояї, у такий спосіб: його посадили на гарячий трон, поклавши на голову розпечену залізну корону. У зв'язку з цим страшним способом страти Шандор Маркі у своїй книги зазначив: «ми повинні відкинути казку про розпечений трон ... яким би не був сильним дух і фізична сила Д'єрдя Дожі, він не міг би витримати таких катувань» [7].

Страта Д'єрдя Дожі могла відбутися в середині липня 1514 року в Темешварі (сьогодні м. Timișoara, Румунія) у присутності величезного натовпу, що зібрався добровільно чи примусово. Ймовірно ця страта мала психологічне підгрунтя - шляхта мала намір цим показати приклад долі лідера повстанців проти існуючого суспільного ладу. Роздягнутого догола Дожу прив'язали до великого крісла, а потім кат насадив на голову засудженого розпечений залізний обруч. У зв'язку з цим сучасник Д'єрдь Серемі у своїй хроніці писав: «Вони наказали фараонам (циганам - автор) виготовити залізну корону, яку поклали у вогонь і витягли їі з вогню кліщами, а розпечену корону посадили на голову Дожі. Кажуть, що при цьому Дожа навіть не ворухнувся і терпляче переносив усе це, а корону вдруге поклали у вогонь, щоб ще розжарити їі і знову покласти на головую. І в тре$m \epsilon »[12]$. Експерти, що реконструювали страту, дійшли висновку, що Д'єрдь Дожа практично втратив свідомість за лічені хвилини після «коронування», а потім помер, чим і пояснюється, що він переносив далі катування безголосно. Це припущення підтверджується й іншим сучасником, каноніком Іштваном Таурінусом, який пише, що під дією розпеченої корони: «... із розколотого черепа виплеснулася рідина, його мозок витікав через вуха, рот і ніс ...» [11]. Розпечений трон, безумовно легенда, оскільки жоден сучасник не згадує про неї, про це не йдеться і в листі угорського і чеського короля Владислава II до імператора Максиміліана: «Повідомляємо, що Д'єрдя Секелі, організатора повстання, на день Апостолів (15 липня), коли він напав на Темешвар... трансільванський воєвода схопив... Згаданого Д'єрдя Секелі спочатку коронували розпеченою залізною короною, а потім голого зі зав'язаними ногами, коли він був ще живий, 
його воїни... зубами розривали і жерли. Зрештою труп четвертували і повісили на шибениці» [6]. Цю історію підтверджує німецький очевидець, один із слуг маркграфа Д’єрдя Гогенцоллерна на ім'я Кріштоф, який нібито був присутнім на страті. Опис було опубліковано в листівці, що з'явилася в Німеччині, за якою: «... вони схопили його, роздягли і посадили у високе крісло. Потім виготовили для нього коронку із залізного обруча, розпекли цю корону і посадили на його голову ...» [3]. Розпечений трон Д'єрдя Дожи, безумовно, є пізнішою вигадкою, точніше пов'язаною з іменем поета Шандора Петефі, який у своїй вірші «Іменем народу» пов'язував цей мотив з особою Дожі: «Чи чули новину про Д'єрдя Дожу? / Спалили його на залізному троні, / Але його дух не горить у вогні, / Тому що він сам вогонь; стережіться: це полум'я знову спустошитиме вас!»

Водночас дивно, що за винятком ватажків, не було великих розплат серед селян. Переважно самі поміщики захищали своїх селян, оскільки, всупереч поширеній думці, селянська війна Дожи багато в чому відрізнялася від таких подій в інших частинах Європи, включаючи, серед іншого, той факт, що у повстанні на боці кріпаків боролася значна кі- лькість представників дрібної і середньої шляхти. Сукупне різке погіршення економічних умов і зростаюча напруженість у зовнішній та внутрішній політиці призвели до того, що антитурецька кампанія переросла згодом у криваве повстання. Відповідальність історика: встановити, що винними за спалах цієї боротьби є обидві сторони (шляхта і селянство). У зв'язку з придушенням селянської війни європейська література зазначає, що закони 1514 року скасували право вільного переселення кріпаків, і таким чином почалося формування «другого кріпацства». Однак реальність така, що ті кріпаки, які не брали участі в повстанні, могли зберегти свою свободу переселення. Але навіть ці, названі драконівськими, заходи не могли бути реалізовані, тому що самі поміщики перешкоджали засудженню своїх селян. Пізніше заборону на переселення було знято: у 1531 році Янош I (Сапояї), а у 1547 році король Фердинанд I (Габсбург) знову дозволили селянам вільно переселятися. За останні роки історична наука багато зробила для «переформатування» історичної постаті Д'єрдя Дожі, але ще залишилося багато «білих плям», яких варто заповнити фарбами. Ця робота буде виконаня у наступних наукових роботах.

\section{Список використаних джерел}

1. E. Kovács Péter. Dózsa György 1514-2014. // Magyar Tudomány, 2014 [Електронний ресурс] // Режим доступу: http:// www.matud.iif.hu/2015/01/10.htm.

2. Fekete, Nagy Antonius, Victor Kenéz, Ladislaus Solymosi, Geisa Érszegi, eds. Monumenta rusticorum in Hungaria rebellium anno MDXIV. Akadémiai Kiadó: Budapest. 1979. 727. old.

3. Geréb László. A magyar parasztháborúk irodalma, 1437-1514. Budapest, 1950107 old.

4. Hámori Péter. Dózsa György két élete és két halála. // [Електронний pecypc] // Режим доступу: http:// www.hitelfolyoirat.hu/sites/default/files/pdf/02-hamori.pdf.

5. Heltai Gáspár. Krónika a magyaroknak dolgairól// Budapest: Magyar Helikon. // [Електронний ресурс] // Режим доступу: - http://mek.oszk.hu/06400/06417/html/heltaiga0070001.html.

6. Karácsonyi János. Egykorú tudósítások az 1514-iki pórlázadásról. //Történelemi Tár -1891 - 337-340 old.

7. Márki Sándor. Dósa György. Budapest: Atheaneum Kiadó, 1913. 535 old.

8. Pataki Zoltán. Dózsa Györgyről, tények és „belelátások”, művészeti ábrázolások tükrében. // [Електронний ресурс] // Режим доступу: http://www.nyugatijelen.com/jelenido/dozsa_gyorgyrol_tenyek_es_belelatasok_muveszeti_abrazolasok_tukreb en.php.

9. Pomogáts Béla. Dózsa György alakja a magyar irodalomban. A Dózsa György vezette parasztfelkelés 500. évfordulójára // Nyelvünk és Kultúránk. 2014.05.03. // [Електронний ресурс] // Режим доступу: http://www.mnyknt.hu/index.php? option $=$ com_content\&view $=$ article \&id $=1520$ :dozsa-gyoergy-alakja-a-magyar-koelteszetben $\&$ catid $=41$ : nyekcikkek\&Itemid=68.

10. Romsics Ignác: Székely Dózsa György. Haramia és/vagy népvezér? // Rubicon történelmi folyóirat 2014 3. sz. // [Електронний ресурс] // Режим доступу: http://www.rubicon.hu/romsics_ignac_szekely_dozsa_gyorgy_hara mia_es_ vagy_nepvezer $/ 1 / 1 / 0$

11. Stephanus Taurinus Olomucensis. Stauromachia id est Cruciatorum Servile Bellum (szerk. Juhász László). Budapest: Királyi Magyar Egyetemi Nyomda, 1944. - 89 old.

12. Szerémi György. Magyarország romlásáról. Budapest: Magyar Helikon, 1961. 318 old.

13. Tubero Lajos. Ommpntariorum de temporibus suis libri. Francofurti [Frankfurt]: 1603. - 287-294. old.

14. Veráncsics Antal összes munkái. (Magy. tört. emlékek 3.) 2. k. Pest: Akadémiai Kiadó, 1857. 5-14. old. 


\section{Йовжа О. Новизна в оценке исторических фигуры Дьердя Дожи к 500-летию крестьян- ской войны}

В научной статье изучаем новые подходы в оценке исторической наукой фигуры руководителя крестьянской войны 1514 г. Дьердь Дожи, причины, ход и подавления крестьянского восстания, а также изменения в историографии оценки крестьянской войны. Стараемся дать новую трактовку исторического процесса, который, в свою очередь, стал одним из предпосылок потери независимости Венгерского королевства после 1526 г.

Ключевые слова: крестьяне, восстание, казнь, дворянство, Дьердь Дожа.

\section{Józsa Attila Novelty in the evaluation of the historical figures of György Dozsa to the 500th an- niversary of the peasant uprising}

The 500th anniversary of the Dozsa's peasant uprising by all means would be a worthy chance to reevaluate the social role of the nobility and peasants. On the periphery of the Hungarian Kingdom (Upper Tisza Region or Transylvania) the nobility of the concerning its material situation and way of life did not differ much from the peasants living together with them, that is why their goals were mutual in many cases. That fact is also emphasized by the struggles for independence which took their beginning from there, the periphery, and in which the representatives of the nobility and the peasants were fighting shoulder to shoulder.

The uprising as a whole was spontaneous, it had no clearly defined goals. But historians find in it elements of the ideology of equality, the benchmark for which the congregation of Szekei close to it could serve. The specifics of the crusade, the preaching activity of the Franciscan observants contributed to the formation of the insurgents' image of themselves as God's chosen people, who are designed to combat not only the Turks, the "natural enemies of Christians", but "infidel and vile gentlemen" who are no less than the Turks, enemies for simple people.

The assessment of the personality and activities of the Dozsa in literature and in tradition changed: in the revolutionary poetry of Sandor Petöfi and the scientific literature of the socialist era, he was praised as a fighter for freedom and justice, in the XIX century and in recent decades, it is treated with a fair amount of skepticism.

In a scientific article we study new approaches in the evaluation by historical science of the figure of the head of the 1514 peasant war, György Dozsa, the causes, course and suppression of the peasant uprising, as well as changes in the historiography of the peasant war. We try to give a new interpretation of the historical process, which, in turn, has become one of the prerequisites for the loss of independence of the Hungarian kingdom after 1526.

Keywords: peasants, uprising, execution, nobility, György Dozsa. 
DOI: 10.33310/2519-2809-2019-47-1-67-75

УдК 94(44)"1891/1918":929 Раковський

\author{
ЯРОСЛАВ ШКАБУРА \\ Аспірант історичного факультету, \\ заступник директора Центра болгаристики \\ та балканських досліджень імені Марина Дринова, \\ Харківський національний університет імені В. Н. Каразіна \\ м. Харків, Україна \\ e-mail: ya.shkabura@gmail.com
}

\title{
КРЕСТЮ РАКОВСЬКИЙ: АНАРХІСТ-РЕВОЛЮЦІОНЕР ЧИ ДОБРОПОРЯДНИЙ ГРОМАДЯНИН (1891-1918 рр.)? (ЗА МАТЕРІАЛАМИ АРХІВА ФРАНЦУЗЬКОЇ ПОЛІЦЇ)
}

\begin{abstract}
Стаття присвячена аналізу діяльності та сконструйованому на ї̈ основі образу відомого активіста міжнародного соціалістичного руху, політичного та дипломатичного діяча СРСР Християна Раковського під час його перебування у Франції в період 1891-1918 рр. крізь призму документів архіву французької поліції. Під час дослідження ми прийшли до висновків, що офіційний Париж, спираючись на доповіді префектів, сприймав Раковського як потенційну загрозу для своєї внутрішньої безпеки, який активно контактував з анархістами, але конкретних фактів порушення ним законів зафіксовано не було. Загалом домінують нейтральні чи навіть цілком позитивні характеристики щодо нього. Вочевидь, це було викликано не стільки принципами моралі (у більш пізніх документах ми зустрічаєм виявлені факти протиправної діяльності, як, наприклад, замовлення та використання підробленого паспорта), а тим, що він знав про встановлене за ним стеження. Тим не менш, збереження образу добропорядного громадянина дозволило Раковському зменшити увагу до себе зі сторони органів безпеки та розширювати коло знайомств у Франції, в тому числі і серед відомих політичних діячів, що у подальшому позитивно вплинуло вже під час його роботи у якості повпреда СРСР в Парижі.

Ключові слова: Раковський, Франція, соціаліст, анархіст, поліція.
\end{abstract}

Постановка проблеми. Християн Раковський залишив після себе досить видатний слід в історії кінця XIX - першої третини XX ст. Зараз його перш за все пам'ятають як радянського політичного і дипломатичного діяча. Але шлях до високих посад, які Х. Раковський займав в різні періоди свого життя, багато в чому почався з його діяльності у Франції, в якій він навчався, захистив дисертацію, завів ряд знайомств серед політичних діячів та громадських активістів, розвивав свої ораторські здібності, публікував статті у різних періодичних виданнях. Його активність, безумовно, не могла не привернути увагу органів безпеки Третьої Республіки. Ким же бачила французька поліція болгарина Х. Раковського? Анархістомреволюціонером або добропорядним громадянином? Загрозою або черговим звичайним іноземцем? Які його дії приводили до форму- вання тієї чи іншої оцінки щодо нього у французькій поліції? Відповіді на ці запитання $\epsilon$ важливими і для виявлення рівня активності $\mathrm{X}$. Раковського у Третій Республіці, і для формування повноцінного єдиного образу болгарського соціаліста крізь призму сприйняття його різними французькими колами (перш за все - органами безпеки, а завдяки звітам префектів поліції - вищими політичними колами, куди потрапляв аналіз цих документів). Так як розгляд всього періоду діяльності X. Раковського у Франції $є$ вкрай великою проблематикою - ми сконцентрували увагу на періоді від його першої появи на території Третьої Республіки - і до 1918 р., після якого в Парижі $\mathrm{X}$. Раковського починають сприймати вже не як просто активіста міжнародного соціалістичного руху, а як радянського державного діяча, і дещо пізніше - дипломата. 
Аналіз основних досліджень і публікацій. Проблематика статті протягом багатьох років залишалася недослідженою, перш за все - в силу об'єктивних причин: довгий час доступ до архівних документів поліцейських звітів був обмежений або закритий. Вперше матеріали правоохоронних органів, які стосуються Раковського, використав французький дослідник Ф. Конт [6] в своїй фундаментальній роботі, що охоплює всю біографію соціаліста. Цей епізод мав місце лише у одній 3 приміток з посиланням на «Папку Раковський-Інсаров», що зберігалась у Міністерстві внутрішніх справ [6, p. 59]. Згодом інший дослідник, П. Бруе [5] в своїй грунтовній монографії вже у декількох місцях згадує поліцейські архіви як джерело інформації щодо подій у біографії Християна Георгійовича (стосовно його перебування у Франції у 1892 р., а також - переліку адрес у Парижі, де він зупинявся протягом $1890-х$ років [5, р. 29; р. 79]). У роботах болгарських дослідників П. Атанасової [1] та Ф. Панайотова [3] «французький сюжет» біографії Х. Раковського, особливо його юних років, описаний вкрай слабо. В цілому зафіксоване активне зміцнення соціалістичних ідей в болгарина, вказується на збільшення кількість знайомих серед видних європейських, перш за все - французьких, соціалістів (торкаючись останнього питання $\Phi$. Панайотов трохи більш докладно зупиняється на взаєминах з такою відомою особою, як Жюль Гед), дається коротка характеристика про роботу Раковського в періодичних виданнях Третьої Республіки. Вітчизняні дослідники Г. Чернявський, М. Станчев і М. Тортіка (Лобанова) [4] в своїй детальній та вагомій роботі вказують (торкаючись періоду 18921918 рр.), серед іншого, на еволюцію зближення поглядів Х. Раковського з французькими соціалістами. Автори приділяють певну увагу і сюжету вивчення болгарином медицини, і подальшої її практики на території Третьої Республіки. Так чи інакше, крім Ф. Конта та П. Бруе жоден з дослідників на даний момент не робив посилання на французькі поліцейські архіви. Це дозволяє нам, грунтуючись на масиві неопублікованих і не використаних раніше архівних документах, вперше вводячи їх в науковий обіг, провести аналіз активності та образу Кр. Раковського в ранній період його діяльності в Третьою Республіці (який ми пропонуємо обмежити 1891-1918 рр.) крізь призму комплексу унікальних документів. Відразу відзначимо, що в архіві поліції, який зараз зберігається в Національних архівах Франції (Archives nationales), $є$ окреме досьє, яке присвячене Раковському [7]. Основна проблема вивчення і подальшого використання документів, які в ньому містяться (там налічується понад 800 аркушів документів) полягає в тому, що листи - не пронумеровані. Тому в нижчевикладеній статті ми, не маючи іншої можливості, будемо робити посилання на папку в цілому, а не на окремі листи (при цьому ми будемо вказувати дату, яка зазначена в тому чи іншому документі для більш швидкої та простої їх ідентифікації).

Так як використані нами документи вперше вводяться в науковий обіг - необхідно приділити деяку увагу їх аналізу як джерельному комплексу. У досьє представлено досить широкий спектр різних документів. Стосовно періоду, який цікавить нас (18911918 рр.), в основному їх можна умовно розділити на декілька наступних груп. По-перше звіти агентів, які безпосередньо спостерігали за Раковським, його пересуваннями, контактами, при цьому іноді навіть вдаючись в такі подробиці, як опис одягу болгарина. Подруге - це звіти префектів поліції тих чи інших регіонів Франції, адресовані у відповідь на запити з Парижа, перш за все - від головного Префекта поліції: у них як правило повідомлялася систематизована інформація про активності Х. Раковського в конкретному регіоні або місті з моменту його появи там - i до його від'їзду. Відзначимо, що деякі такі звіти супроводжувалися короткою інформаційною карткою з докладними загальними даними про цього болгарина: наприклад, ім'я та прізвище батьків і навіть зріст, колір волосся та очей, форма зачіски і наявність бороди. По-третє - це листування між головним Префектом і Прем'єр-міністром і міністрами Франції: в основному, це запити про надання поліцією (під чиїм керівництвом знаходилось і бюро Управління загальної безпеки з відділом Контролю за іноземцями) детальної ін- 
формації про діяльність Раковського на території Третьої Республіки і чи несе він потенційну небезпеку країні як анархіст (деякі документи цього типу мають гриф «Таємно»). По-четверте - це запити іноземних представників (зокрема - Румунії та Угорщини) в Париж до деяких міністрів та Префекта щодо надання або уточнення тієї чи іншої інформації про Х. Раковського. В цілому ж відзначимо, що у всіх проаналізованих і використаних документах простежується тенденція до викладу виключно фактів і побудованих на них висновках. Істотно емоційно забарвлених або відверто упереджених оцінок і характеристик нами помічено не було.

Метою статті є: проаналізувати діяльність та виокремити сконструйований на ї̈ основі образу Християна Раковського під час його перебування у Франції в період 18911918 рр. крізь призму документів архіву французької поліції; виявити, за яких умов формувався цей образу, та визначити його вплив на подальшу діяльність Раковського у Парижі вже у якості радянського представника.

Виклад основного матеріалу. Християн Раковський народився 1 серпня 1873 року в болгарському місті Котел в родині Георгія i Марії Станчевих, при народженні назвавши сина Кристю. Його мати Марія, в дівоцтві Тирпанська, була внучатою племінницею Георгія Раковського - одного з відомих діячів національно-визвольного руху Болгарії. Перш за все саме в честь свого знаменитого родича він ще 3 юнацьких років вирішив взяти прізвище Раковський, під яким згодом і фігурував у більшості французьких поліцейських звітах. Кілька разів в них зустрічається прізвище «Станчев», але як правило - лише в якості уточнення. Також відразу зазначимо, що майже у всіх документах, на які ми спиралися при написанні цієї статті, ім'я Раковського написано як Крестю (Krestu), ім'я Християн (Christian) - досить рідко, і починаючи лише 3 звітів, що датуються 1908 р. Ці особливості необхідно було позначити для кращого сприйняття викладеного нижче матеріалу.

Вперше К. Раковський потрапляє в поле зору органів безпеки Франції в 1891 р. Так, в поліцейському звіті від 23 листопада говориться про те, що Крестю отримав з Парижу від Жоржа Крєпіна «пакет брошур під назвою "Колективізм" - конференції пана Жюля Геда в Товаристві соціальних і політичних досліджень Брюсселя», після чого «пан Раковський відразу ж поширив ці студентські листівки в рамках Міжнародного кола, а також кількох своїх друзів в групі російських біженців» [7]. Таким чином стає очевидним - станом на 1891 рік у Крестю вже були якісь зв'язки, контакти з Францією, що дозволили йому отримати таку посилку. Визначити, коли та за яких умов він їх отримав, як, втім, і дату його першої поїздки в Третю Республіку - залишається досить складним. Наприклад, у вже згаданому вище звіті говориться, що К. Раковський в 1891 р провів свої «останні канікули» в Морно (департамент Верхня Савойя), де він мав контакти з відомими соціалістами Г. Плехановим і В. Засулич, представниками «забороненої в Женеві групи» [7]. 3 іншого боку, в документі, складеному в березні 1901 року і адресованому Прем'єр-міністру Третьої Республіки Префект поліції пише, що «Раковський Крестю ... зупинявся в Бонді (Сена) з лютого 1889 до початку 1890 рр., потім - в Парижі, до січня 1891 р.» [7]. Подібна інформація, що Крестю вперше прибуває до Франції в 1889 р. - зустрічається тільки раз; в інших документах щодо цього питання відлік починається з 1891 р. В будь-якому випадку, обидві вищезгадані дати вказують на те, що К. Раковський побував на території Третьої Республіки як мінімум на рік раніше, ніж про це писали дослідники, які займалися вивченням біографії цього соціаліста $[1$, с. $13 ; 3$, c. $97 ; 4$, c. $28 ; 5$, p. $30 ; 6$, p. 30].

Встановлення К. Раковським зв'язків 3 соціалістами з заборонених в сусідніх країнах груп викликало певну зацікавленість з боку французької поліції. У наступному, 1892 р. ми зустрічаємо згадка, що Крестю отримав з бібліотеки Нансі цілий ряд книг політичної та медичної тематики. Ще більшу увагу поліції він почав привертати після літа того ж року. У рапорті від 18 червня, який знаходився в розділі, що стосується діяльності анархістів, зафіксовано, що «активний член Товариства студентів-соціалістів в Женеві, провів всю свою літню сесію в Монетьє-Морно, в компанії декількох російських нігілістів і болгарських 
анархістів» [7]. Серед них були виділені Засулич, Плеханов, Балабанов, Стоянов і т.д. Очевидно, фігура Крестю на той момент вже почала викликати особливий інтерес для французької поліції, і для отримання інформації про діяльність болгарина за кордоном була встановлена співпраця з правоохоронними органами сусідніх країн. Так, у вищезгаданому рапорті зустрічається інформація, що в Женеві К. Раковський «також часто відвідує швейцарських і німецьких анархістів і найвідоміших нігілістів» [7].

Далі, після перерви майже в три роки, ми зустрічаємо достатньо цікавий поліцейський звіт від 16 травня 1895 р. 3 одного боку - префект Мьорт-і-Мозель (департамент на північному сході Франції) називав К. Раковського «фігурантом під номером 214 в Списку В анархістів, які проживають за кордоном» [7]. Увага поліції до Крестю в цей період була викликана тим, що останній отримував з Цюріха брошури соціалістичного і анархічного змісту, при цьому - активно обмінювався телеграмами з болгарами Нансі і Парижа. 3 іншого боку - префект чітко і впевнено стверджував: «Раковський ... не займається пропагандою», i «... не встановлено, що він сповідував анархістські ідеї» [7]. Відповідно, «немає ніяких підстав для арешту цього іноземця», $\mathrm{i}$ просто потрібно «продовжувати уважно стежити» [7] за ним. Спостереження тривало, виходячи з більш пізніх звітів, до березня 1899 г. Проте, як зазначено в документах, «нагляд ... більше не дав ніяких результатів» [7].

Справжня хвиля нових повідомлень про К. Раковського з'являється тільки з 1901 р. Ймовірну причину такої малої кількості матеріалів про болгарина можна знайти в ноті керівника відділу контролю за іноземцями від 13 квітня 1901 р. У ній зазначено, що в Бюро Управління загальної безпеки (яке входило до складу МВС Франції), відділі Контролю за іноземцями знаходилась справа щодо Раковського. Як зазначив керівник відділу при створенні цієї справи була допущена помилка: замість дати народження 13 серпня 1873 р. там була записана дата 13 серпня 1837 р. Внаслідок цієї помилки формально вік Крестю перевищив 60 років, i «його файл був знищений» [7]. Який обсяг важливої і вагомої інформації був втрачений у зв'язку з двома переплутаними цифрами - ми можемо лише припускати.

На початку 1901 року К. Раковський подав заяву на натуралізацію. Логічною реакцією з боку поліції стало більш глибоке вивчення всієї біографії цього молодого соціаліста. Префект поліції в своїй доповіді Прем'єрміністру, датованій березнем 1901 р., з цього питання надав ряд важливої інформації. 3 самого початку він підкреслив, що Крестю, відразу після свого прибуття в Нансі 10 листопада 1894 р. «отримав з Цюріха розсилку (а за оцінкою оперативника, який, очевидно, безпосередньо стежив за болгарином, а згодом - і склав «індивідуальне повідомлення» від 5 червня 1895 р., це була не просто розсилка, а справжній «потік» - Прим. авт.) соціалістичних і анархічних памфлетів» [7]. Так само, за інформацією від берлінської поліції, К. Раковський мав «дуже тісні відносини 3 революціонерами різних країн», особливо зі студентами, у яких була виявлена «значна кількість анархістських текстів, а також кореспонденції, яка доводить їх участь у революційній діяльності» [7]. Незважаючи на такі тривожні дані, Префект поліції зазначає, що 3 часу свого прибуття в Нансі «ця людина не вів ніякої пропаганди ..., а його поведінка завжди була коректною» [7]. Під час свого більш пізнього перебування в Монпельє Крестю так само «не викликав ніяких скарг» [7]. В кінці доповіді Прем'єр-міністру щодо К. Раковського зафіксовано наступний висновок: «інформація, зібрана на його рахунок, сприятлива для нього, і він добре представлений в усіх відношеннях» [7].

Спираючись на документи поліцейського архіву щодо періоду, який нас цікавить, ми можемо зробити висновок, що незважаючи на відсутність істотних записів про діяльність Крестю, він вкрай активно і успішно займався встановленням зв'язків в різних сферах французького суспільства. Яскравим підтвердженням цього висновку може служити наступний факт: заяву про натуралізацію молодого соціаліста розглядали на досить високому рівні, зокрема - Прем'єр-міністр Франції, міністри юстиції і внутрішніх справ, 
головний Префект поліції. Більш того, ця заява, за запевненням міністра юстиції, була «об'єктом багатьох рекомендацій» [7]. Саме таке повторюване формулювання ми зустрічаємо в декількох документах початку XX ст., підписаних вищезазначеним високопоставленим чиновником.

У наступний період ми зустрічаємо іноді прямо протилежні точки зору щодо питання про натуралізацію К. Раковського. Так, у звіті префекта поліції Монпельє до міністра внутрішніх справ від 23 травня 1901 року вказується, що в період свого перебування в січніквітні 1896 року з мадам Е. Рябовой (першою дружиною Кр. Раковського) в Монпельє, вони «брали участь у революційних колах і відвідували анархістські зборів» [7]. У зв'язку з цим префект особливо наголошував - «дуже несприятливим» стало б рішення схвалити натуралізацію Раковського. У записці від 10 жовтня 1902 р., складеної відомим французьким політичним та державним діячем, одним із лідерів французьких радикалів Жоржем Клемансо у підтримку Крестю, наголошується на наступному: «хоча він і соціаліст, він не втручався в політику, і ми не бачимо, як його можна дорікнути за "своє політичне минуле"» [7]. В документі, серед іншого, також стверджується, що поданий К. Раковським запит на натуралізацію доповнюють «кілька рекомендацій від сенаторів і депутатів», «експертиза його докторської дисертації і її оцінка в пресі (захист пройшла в 1897 р. і зібрала чимало схвально відгукуються в газетах і журналах того часу, наприклад - в газеті «La Vie Montpelliéraine» від 7 серпня 1897 р. [24, p. 7] - Прим. авт.)», а також - «копія його об'ємної роботи, написаної російською мовою "Сучасна Франція"» і супроводжувана «відгуками, переведеними на французьку мова» [7].

Судячи 3 наступних документів, основною перешкодою на шляху болгарського соціаліста до отримання схвалення на натуралізацію стала не його «революційна і анархістська» діяльність, а порушення одного 3 правил: перед подачею документів необхідно було безперервно протягом 10 років проживати на території Франції. К. Раковський, в свою чергу, у 1897-1899 рр. перебував за ме- жами Третьої Республіки (в основному - в Румунії). Цю інформацію Префект поліції передав Прем'єр-міністру і міністру закордонних справ у своїй доповіді від 23 грудня 1902 p. Цікаво, що в 1907 р. Посольство Румунії у Франції спробувало отримати від французького МЗС і поліції більш детальну інформацію про те, чи депортували К. Раковського 3 територій Третьої Республіки за його активні «анархістські дії» [7]. I не дивлячись на те, що Префект поліції в своїй відповіді Прем'єрміністру та міністру закордонних справ від 17 травня 1907 р. зазначив: «цього іноземця, ... мабуть, не виключали з нашої території» у зв'язку з «політичним причинами» [7], очевидно такі чутки також вплинули на формування в майбутньому образу молодого К. Раковського як європейського анархістареволюціонера. Для того щоб краще зрозуміти, наскільки Крестю сприймали як реальну загрозу для Франції серед представників правоохоронних органів і спецслужб, слід звернутися до доповіді Генеральної поліції для Прем'єр-міністра і міністра закордонних справ (він був складений в травні 1907 року і мав позначки «Терміново. Таємно»), резюме якого зводиться до наступної тези: «Таким чином, д-р Раковський, Крестю, який, можливо, має дуже просунуті політичні ідеї, зовсім не виглядає анархістом» [7].

На тлі вищезазначених оцінок і характеристик Раковського не типовим, але показовим $є$ запит від 15 листопада 1909 р., спрямований з Будапешта в Париж, і адресований директору загальної безпеки Міністерства внутрішніх справ. У ньому угорська сторона просить надати більш точну інформацію щодо Крестю, який спробував в'їхати з території їх країни в Румунію, використовуючи паспорт, виданий 16 квітня 1909 р. у французькому місті Німі (знаходиться недалеко від Монпельє) «під № 28 на ім'я Анрі Жана Верне» [7]. Очевидно, що, не дивлячись на свою показову добропорядність і законослухняність, Крестю не відмовився від ідеї використовувати будь-які шляхи, в тому числі - і не легальні, для досягнення своїх цілей. Продовжуючи заводити різні знайомства, йому, як ми бачимо, вдалося встановити достатньо специфічні зв'язки, які дозволили отримати 
абсолютно новий французький паспорт на чуже ім'я для максимально вільного і непомітного пересування європейськими країнами. Можливо, частково це стало реакцією К. Раковського на неймовірно довгий і безуспішний розгляд його заяви на натуралізацію, подану ще в 1901 р. і при позитивному результаті якого він міг би абсолютно легально отримати французькі документи. Як би там не було, але факт залишається в тому, що Крестю вирішив діяти нелегально. Більш того - видача йому паспорта в обхід законодавства залишилась непоміченою поліцією Франції, у якій він перебував під наглядом. Логічно припустити, що поза увагою правоохоронних органів і служб внутрішньої безпеки могла залишитись активність і в інших сферах, яку проявляв К. Раковський у цій країні. Хоча здавалося б ще в квітні того ж таки 1909 р. болгарський соціаліст знову привернув до себе серйозну увагу поліції: він виступив на «зустрічі, організованій російськими революціонерами», на якій були присутні близько 600 осіб, з темою «Російська зовнішня політика і турецька революція» [7]. «Спікер, який $є$ хорошим пропагандистом i відмінним оратором, сказав, що початок революційного руху в Росії був пов'язаний з лідерами, які недостатньо підготували пролетаріат. Він закликав молодь проявити сміливість і наслідувати приклад младотурков» [7]. Головою цієї зустрічі був відомий політичний діяч, один із засновників Французької комуністичної партії Шарль Раппопорт, 3 яким Кр. Раковський на той момент був знайомий вже досить давно, і який, очевидно, й запросив болгарського соціаліста виступити на даному заході.

Після 1909 р. Крестю на довгий час покинув Третю Республіку, проживаючи поперемінно то в Болгарії, то в Румунії. Інформація про нього у Франції з'являлася доволі не часто i, як правило, лише в газетах. Проте через декілька років ситуація знову змінилась. У Парижі в 1915 р. з'явилась, як її охарактеризували в поліцейських звітах, «російська» «максималістська газета "Наше слово"» [7]. К. Раковський фігурував як «один із засновників», а також - як людина, що здійснює фінансування цієї газети. «Наше слово» видава- лось до 1916 р. Поліція уважно стежила за матеріалами, які публікувалися в газеті. Але, незважаючи на активну політичну позицію, яку він демонстрував і поширювану через «Наше слово», К. Раковський продовжував офіційно залишатись законослухняним громадянином. Судячи з поліцейським звітам, ні в фінансованій Крестю газеті в цілому, ні в окремих статтях, що стосувалися болгарського соціаліста, так і не було знайдено матеріалу, який би вказував на порушення цим іноземцем французьких законів. Але така активності з використанням преси в Парижі все ж викликала певну тривогу: через рік після закриття «Нашого слова», в звіті від 3 листопада 1917 року ми знаходимо побоювання одного з оперативників, що К. Раковський може надати «фінансову підтримку російській газеті «Отклики», яка тільки що була заснована» в столиці Франції [7].

У цей період ми спостерігаємо і можливий вплив преси на формування поліцейських звітів. Виходячи з документів 1915 р К. Раковського називали «агентом Австрії» [7] тільки в пресі, і лише «російські публіцисти Амфітеатроф (Amphitheatroff) і Алексинський (Alexinsky)» [7] - саме на них посилаються представники органів безпеки. Але вже в звіті від 4 березня 1916 року ми зустрічаємо наступне безапеляційне твердження: «загальновідомо, що ... соціаліст Раковський $\epsilon$ політичним агентом Австрії» [7]. Відзначимо, що ніяких конкретних аргументів поліції на користь цієї тези ні в даному, ні в більш ранніх звітах нами виявлено не було (крім як, повторимося, кількох згадок, пов'язаних 3 французькою пресою). Тезу про те, що К. Раковського «субсидувала Австрія» чи він був «шпигуном Німеччини» французька преса активно підхопила в 1917 р., і це знайшло своє відображення в публікаціях різних видань (напр., «La République française» [9, p. 2], «Le Matin» [12, p. 1], «Le Figaro» [23, p. 2], «Le Radical» [8, p. 2].

Але очевидно, що К. Раковський у цей період намагався діяти не тільки використовуючи деякі паризькі російськомовні газети, а й іншими способами. Наприклад - через свою дружину. Після тривалого спостереження за Крестю, французька поліція почала стежити i 
за діяльністю його дружини. Це дало певний результат. У поліцейському звіті, датованому 20 грудня 1918 р. зафіксована інформація про існування ймовірності, «що мадам Раковська, дружина румунського радянського діяча болгарського походження, яка в даний час $\epsilon$ частиною радянського уряду, зараз збирає значні суми для пропаганди в країнах Антанти» [7]. Про цю потенційну небезпеку і стосовно Франції були відразу поінформовані відповідні органи.

Висновки і перспективи дослідження. 3 перших днів свого перебування на теритоpiї Франції, К. Раковський викликав до себе досить пильну увагу з боку правоохоронних органів. Це було цілком логічним, адже від колег інших європейських країн надходили сигнали, що Крестю тісно спілкувався з анархістами, нігілістами і представниками заборонених груп. Судячи з більшості поліцейських звітів - на території Франції Раковський поводився законослухняно, не викликав ніяких скарг, політичною агітацією особливо не займався і майже ніяк не демонстрував свою активність, намагаючись особливо не привертати до себе зайвої уваги. Розглядаючи архівні документи міністерства внутрішніх справ - ми отримуємо образ доброчесного і благонадійного громадянина, що має «просунуті політичні ідеї». Але більш ретельне вивчення поліцейських звітів дає нам можливість зробити й інший висновок. Х. Раковський, як він згадував у своїй автобіографії, знав, що за ним стежить поліція, i «розширювати свою діяльність», особливо в період 1895-1899 рр., «не міг» [2, с. 611], що чітко простежується по документам. Привернувши увагу правоохоронних органів після прибуття до Франції, Крестю максимально зменшив свою активність. Після декількох років фактично безрезультатних спостережень поліція все менше звертала увагу на
К. Раковського. Так, ні в одному зі звітів не знайшла відображення його робота у французькій пресі (наприклад, його публікації в «La Vie Socialist» [10; 11], «Revue de La Paix» [13; 16; 18], «Le Socialisme» [15; 17], «La Petite République» [19; 20; 21; 22], «Le Mouvement Socialiste» [14]), хоча він й не використовував псевдонім, і підписувався абсолютно відкрито. Крестю успішно заводив знайомства в різних сферах, в тому числі і серед відомих французьких політиків. Результатом стали рекомендації на підтримку К. Раковського від деяких депутатів і сенаторів в питанні про натуралізацію. Інші знайомства дозволили йому діяти поза межами закону: отримати новий французький паспорт на чуже прізвище і використовувати його для переміщення по Європі. Можливо ще більше інформації ми змогли б почерпнути зі справи про К. Раковського, яка зберігалась у відділі Контролю за іноземцями Бюро Управління загальної безпеки. Але воно, на жаль, було знищено. Офіційна версія говорить, що причиною стала канцелярська помилка. Проте, виходячи 3 зазначених у статті фактів та процитованих документів, ми розглядаємо як цілком реальну версію, що позбутися від якоїсь несприятливої інформації болгарському соціалісту допомогли його нові французькі друзі. Так чи інакше, образ Крестю - Християна Раковського, який був сформований поліцейськими звітами, і який фігурував в документах, переданих Прем'єр-міністру і міністрам, був вельми позитивним, тобто його сприймали не стільки як анархіста, скільки як добропорядного громадянина. Очевидно, це стало однією 3 причин досить теплого прийому в Парижі і деяких успіхів X. Раковського як представника СРСР у Франції в середині 20-х років XX століття. Більш детально 3 цим питанням нам допоможе розібратися подальше поглиблене дослідження окресленої проблематики.

\section{Список використаних джерел}

1. Атанасова, П. Крыстю Раковский: 1873-1941. София: София пресс, 1988. 56 с.

2. Деятели СССР и революционного движения России. Энциклопедический словарь «Гранат». Москва: Изд. «Советская энциклопедия», 1989. 832 с.

3. Панайотов, Ф. Животът и смъртта на Кръстю Раковски. София, Издателство «ЗАХАРИЙ СТОЯНОВ», 2003. 555 с.

4. Чернявский, Г.И. Жизненный путь Христиана Раковского. Европеизм и большевизм: неоконченная дуэль. М.: 3 АО Издательство Центрполиграф, 2014. 556 с.

5. Broué, P. Rakovsky ou la Révolution dans tous les pays. Fayard, 1996. 462 p.

6. Conte, F. Christian Rakovski (1873-1941). Essai de biographie politique. Lille: Atelier reproduction des thèses, Université Lille III, 1975.898 p. 
7. Direction de la Sûreté nationale (1876-1966), RAKOWSKI-INSAROW Fonction. Archives nationales. F/7/15999/2.

8. L'infortunée Roumanie. Le Radical. 1917. 10 décambre. P. 2.

9. Les Evénements de Russie. La position de l’armee roumaine. La République française. 1917. 9 décembre. (№ 15918). P. 2.

10. La Vie Socialist: revue bi-mensuelle internationale. 1904. 20 novembre. (№ 2). P. 2.

11. La Vie Socialist: revue bi-mensuelle internationale. 1904. 05 décembre. (№ 3). P. 2.

12. Les excès des bolcheviks. Le Matin. 1917. 9 décembre. (№ 12339). P. 1.

13. Racovski C. Between Two Thieves. Russia and Austria in Serbia / trans.: Harry Ratner. Revue de La Paix. 1909. Avril. P. 4-5. URL: http://www.marxistsfr.org/archive/rakovsky/1909/04/x01.htm (Last accessed: 27.03.2019).

14. Rakowsky C. La décadence de l'esprit nationalist. Le Mouvement socialiste: revue bi-mensuelle internationale. 1905.15 juillet. (№ 159). P. 378-391.

15. Rakovsky C. Revolution and Counter Revolution in Turkey / trans.: Harry Ratner. Le Socialisme. 1909. 15 mai. P. 4-5. URL: http://www.marxistsfr.org/archive/rakovsky/1909/05/15.htm (Last accessed: 27.03.2019).

16. Rakovsky C. The Eastern European Question and the Great Powers / trans.: Harry Ratner. Revue de La Paix. 1908. Novembre. P. 1-2. URL: http://www.marxistsfr.org/archive/rakovsky/1908/11/x01.htm (Last accessed: 27.03.2019).

17. Rakovsky C. The Turkish Revolution / trans.: Harry Ratner. Le Socialisme. 1908. 1 août. P. 1-2. URL: http:// www.marxistsfr.org/archive/rakovsky/1908/08/01.htm (Last accessed: 27.03.2019).

18. Rakovsky C. Towards a Balkan Entente / trans.: Harry Ratner. Revue de La Paix. 1908. Décembre. URL: http:// www.marxistsfr.org/archive/rakovsky/1908/12/x01.htm (Last accessed: 27.03.2019).

19. Rakowsky K. La Question d'Orient et le Parti Socialiste international (partie I). La Petite République. 1897. 14 avril. (№ 7670). P. 2.

20. Rakowsky K. La Question d'Orient et le Parti Socialiste international (partie II). La Petite République. 1897. 15 avril. (№ 7671). P. 2.

21. Rakowsky K. La Question d'Orient et le Parti Socialiste international (partie III). La Petite République. 1897. 16 avril. (№ 7672). P. 2.

22. Rakowsky K. Les Responsabilités. La Petite République. 1897. 23 avril. (№ 7679). P. 2.

23. Une déclaration de M. Antonesco. Le Figaro. 1917. 9 décembre. (№ 343). P. 2.

24. Université de Montpellier. La Vie Montpelliéraine. 1897. 7 août. (№ 151). P. 7.

\section{References}

1. Anon., 1897. Université de Montpellier [University of Montpellier]. La Vie Montpelliéraine, № 151, p.7.

2. Anon., 1917. L'infortunée Roumanie [The unfortunate Romania.]. Le Radical, A38, Paris, p.2.

3. Anon., 1917. Les Evénements de Russie. La position de l'armee roumaine [The Events of Russia. The position of the Romanian army]. La République française, № 15918, p.2.

4. Anon., 1917. Les excès des bolcheviks [The excesses of the Bolsheviks]. Le Matin, № 12339, Paris, p.1.

5. Anon., 1917. Une déclaration de M. Antonesco [A statement by Mr. Antonesco]. Le Figaro, № 343, p.2.

6. Atanasova, P., 1988. Krystyu Rakovskiy: 1873-1941 [Krystyu Rakovsky]. Sofia: Sofiya press.

7. Broué, P., 1996. Rakovsky ou la Révolution dans tous les pays [Rakovsky or the Revolution in all countries]. Fayard.

8. Chernyavskiy, G.I., 2014. Zhiznennyy put Khristiana Rakovskogo. Yevropeizm i bolshevizm: neokonchennaya duel [The life path of Christian Rakovsky. Europeanism and Bolshevism: unfinished duel]. Moscow: ZAO Izdatelstvo Tsentrpoligraf.

9. Conte, F., 1975. Christian Rakovski (1873-1941). Essai de biographie politique [Christian Rakovski (1873-1941). Political biography essay]. Lille: Atelier reproduction des thèses, Université Lille III.

10. Deyateli SSSR i revolyutsionnogo dvizheniya Rossii. Entsiklopedicheskiy slovar «Granat» [Figures of the USSR and the revolutionary movement of Russia. Encyclopedic dictionary "Pomegranate"]. Moscow: Izd. «Sovetskaya entsiklopediya».

11. Direction de la Sûreté nationale (1876-1966), RAKOWSKI-INSAROW Fonction [Directorate of National Security (1876-1966), RAKOWSKI-INSAROW Function]. Archives nationales. F/7/15999/2.

12. Panayotov, F., 2003. Zhivott i smrtta na Krstyu Rakovski [The Life and Death of Krastyu Rakovski]. Sofia: Izdatelstvo «ZAKHARIY STOYANOV».

13. Pressensé, F. de, red., 1904. La Vie Socialist: revue bi-mensuelle internationale, № 2, Paris, p.2.

14. Pressensé, F. de, red., 1904. La Vie Socialist: revue bi-mensuelle internationale, № 3, Paris, p.2.

15. Rakowsky, C., 1905. La décadence de l'esprit nationalist [The decadence of the nationalist spirit]. Le Mouvement socialiste: revue bi-mensuelle internationale, № 159, pp.378-391.

16. Rakovsky, C., 1908. The Eastern European Question and the Great Powers / trans.: Harry Ratner. Revue de La Paix, [online] Available at:<http://www.marxistsfr.org/archive/rakovsky/1908/11/x01.htm> [Accessed 27 March 2019].

17. Rakovsky, C., 1908. The Turkish Revolution / trans.: Harry Ratner. Le Socialisme, [online] Available at:<http:// www.marxistsfr.org/archive/rakovsky/1908/08/01.htm> [Accessed 27 March 2019].

18. Rakovsky, C., 1908. Towards a Balkan Entente / trans.: Harry Ratner. Revue de La Paix, [online] Available at:<http:// www.marxistsfr.org/archive/rakovsky/1908/12/x01.htm> [Accessed 27 March 2019].

19. Racovski, C., 1909. Between Two Thieves. Russia and Austria in Serbia / trans.: Harry Ratner. Revue de La Paix, [online] Available at:<http://www.marxistsfr.org/archive/rakovsky/1909/04/x01.htm> [Accessed 27 March 2019].

20. Rakovsky, C., 1909. Revolution and Counter Revolution in Turkey / trans.: Harry Ratner. Le Socialisme, [online] Available at:<http://www.marxistsfr.org/archive/rakovsky/1909/05/15.htm> [Accessed 27 March 2019].

21. Rakowsky, K., 1897. La Question d'Orient et le Parti Socialiste international (partie I) [The Eastern Question and the International Socialist Party (Part I)]. La Petite République, № 7670, p. 2.

22. Rakowsky, K., 1897. La Question d'Orient et le Parti Socialiste international (partie II) [The Eastern Question and the International Socialist Party (Part II)]. La Petite République, № 7671, p. 2.

23. Rakowsky, K., 1897. La Question d'Orient et le Parti Socialiste international (partie III) [The Eastern Question and the International Socialist Party (Part III)]. La Petite République, № 7672, p. 2.

24. Rakowsky, K., 1897. Les Responsabilités [Responsibilities]. La Petite République, № 7679, p. 2. 


\section{Шкабура Я. Крестю раковский: анархист-революционер или добропорядочный гражда- нин (1891-1918 гг.)? (по материалам архива французской полиции)}

Статья посвящена анализу деятельности и сконструированном на ее основе образе известного активиста международного социалистического движения, политического и дипломатического деятеля СССР Христиана Раковского во время его пребывания во Франции в период 1891-1918 г2. сквозь призму документов архива французской полиции. В ходе исследования мы пришли к выводу, что официальный Париж, опираясь на доклады префектов, воспринимал Раковского как потенциальную угрозу своей внутренней безопасности, и который активно контактировал с анархистами, но конкретных фактов нарушения им законов зафиксировано не было. В целом доминируют нейтральные или даже положительные характеристики в отношении него. Очевидно, это было вызвано не столько принципами морали (в более поздних документах мы встречаем выявленные факты противоправной деятельности, как, например, заказ и использование поддельного паспорта), а тем, что он знал о установленной за ним слежке. Тем не менее, сохранение образа добропорядочного гражданина позволило Раковскому уменьшить внимание к себе со стороны органов безопасности и расширять круг знакомств во Франции, в том числе и среди известных политических деятелей, что в дальнейшем положительно повлияло уже во время его работы в качестве полпреда СССР в Париже.

Ключевые слова: Раковский, Франция, социалист, анархист, полиция.

Shkabura Y. Krestu Rakovsky: anarchist-revolutionary or a good citizen (1891-1918)? (according to the materials of the french police archive)

This article analyzes the work and the image of Christian Georgievich Rakovsky. The main focus is on the stay the well-known activist of the international socialist movement, political and diplomatic figure of the USSR in France in 1891-1918.

The purpose of this publication is to trace the main directions of Rakovsky's activities, which attracted the attention of internal security agencies. Furthermore, to demonstrate the image of this socialist; identify that influenced the formation of attitudes towards him; determine what impact this image had on his future activities.

The research is based on the archival documents of the French police, which had never before been comprehensively analyzed by researchers, and almost did not figure in other scientific works.

Rakovsky's personality attracted the attention of French internal security agencies. even before he visited France for the first time, and then they began to spy on him. Despite the rather long period of time, this socialist spent in the Third Republic, he "officially" acted within the law. Although, he constantly showed political and social activity. It is documented that from the first visits he often communicated with various «nihilists», "anarchists» and members of "forbidden groups». Additionally, Rakovsky participated in the public speeches and discussions, got his articles published in the press, etc. However, several documents proof that he did break the law in a few cases. The most striking example is the obtainment of a fake French passport and its usage for secret trips around Europe. According to the police, the detailed investigation and the delay of Rakovsky's naturalization process were caused by the possible threat constituted by his actions. When certain formal violations were discovered he was denied French citizenship.

In one way or another, the police reports convey that Rakovsky was perceived as a person who does not violate the laws and, accordingly, does not pose a threat to France.

Moreover, divers documents include quite positive reports about him. These facts allowed Rakovsky to move freely around the country, to actively participate in public life and make a number of acquaintances with French politicians and civic activists. It can be stated that in the future these ties influenced two important events. Firstly, the recognition of Paris by the USSR during the informal negotiations in the fall of 1924, which took place between Rakovsky and his friend de Monzie. And secondly, the Franco-Soviet relations in the period 1925-1927, when Christian Georgievich served as plenipotentiary of the Soviet Union in Paris.

Keywords: Rakovsky, France, socialist, anarchist, police. 
DOI: 10.33310/2519-2809-2019-47-1-76-82

УДК 94 (439.23) - „16/17”

\author{
ЛАСЛОВ ЗУБАНИЧ \\ кандидат історичних наук \\ доцент кафедри історії Угорщини та європейської інтеграції \\ Ужгородського національного університету \\ м. Ужгород, Україна \\ e-mail:kmoalap@gmail.com
}

\title{
ДВОРЯНСТВО ПІВНІЧНО-СХІДНОЇ УГОРЩИНИ XVI-XVII СТ. -СОЦІАЛЬНО-ЕКОНОМІЧНИЙ АСПЕКТ РОЗВИТКУ
}

\begin{abstract}
У науковій роботі вивчаємо соціально-економічний стан дворянських родин т. з. Верхньої Угорщини (територія сучасного Закарпаття - комітатів Унг, Берег, Угоча, Мароморош), окреслено та проаналізовано етапи розвитку дворянства. На підставі джерельної бази намагаємося дати нове трактування історичної ролі дворянства у процесах XVI-XVII століть, показати їх участі у заселенні території, розвитку сільского господарства, розвитку суспільних відносин.

Ключові слова: дворянство, комітати, родина, садиба, податок, король, грамота, закон.
\end{abstract}

XVI століття стало переломним моментом на шляху розвитку Угорщини: поразка у бою під Могачем 1526-го року; внаслідок встановлення у центральній частині країни турецього панування комітати північносхідної частини Верхньої Угорщини потрапили у буферну зону двох держав - Угорського Королівства та Трансильванського Князівства. Адже на руїнах середньовічної держави утворилися три нові регіони. Їх взаємозалежність, та спільна зовнішня загроза привели до виникнення нового суспільного устрою. Постійна турецька військова загроза, формування системи прикордонних фортець у значній мірі переоцінили суспільні цінності військових елементів, звідки вів прямий шлях до кроку у вищий суспільний клас, у дворянство. Для історичної науки розвиток територій Північно-Східної Угорщини (Ужанський, Березький, Угочанський та Марамороський комітати - більшість території сучасного Закарпаття) варто досліджувати комплексно. Протягом XVI-XVII століть Угорське королівство та Трансільванське князівство були становими монархіями, в яких правитель поділяв владу з представниками вищого суспільного класу. Політичне, економічне та культурне піднесення у країні відбулося з активної участі дворянства.
Українська історична наука практично не досліджувала дане питання, а саме, суспільне та економічне становище дворянських комітатів. Натомість ця тематика має багату угорськомовну літературу. Провідне місце тут займають джерела - документи феішпанських фондів $[1,6]$ різних комітатів Державного архіву Закарпатської області (ДАЗО), а також у Державному архіві Угорського національного архіву. Багато документів було опубліковано у часописах «Турул» та «Сторіччя» Угорського історичного товариства, у «Пам'ятки угорської історії». За останне роки було видоно велику кількість оціфрованих джерел: Corpus Juris Hungarici» - збірник державних декретів і законів (1000-1848 рр.) [5], «Королівські книги» («Liber Regius»). Вони дають чать чітку картину соціально-економічних відносин і комітатах Південно-Східній Угорщині. Багатою $\epsilon$ і монографічна література: історію комітатів, їх дворянських родин описали Антал Чікварі, Іштван Сабов [14], Тиводар Легоцькі [11], Вільмош Бейлаї [9]. В останні роки багато пуплікацій на цю тематику випустив Ласлов Зубанич $[2,3,4,15]$.

Вивчення соціально-економічних відносин Південно-східної Угорщини в XVI-XVII століттях цікаве тому, що до наших днів дійшли не тільки багато архівних матеріалів 
того часу, але й велика кількість різних статистичних звітів. Серед них, зокрема, посадибний опис 1598 р., урбаріальні переписи, які дають чітку картину з життя кожного населенного пункту або володінь певного дворянського роду.

Комітати, як регіональні органи управління та заселені адміністративно-територіальні одиніці Угорського Королівства у формі жуп були утворені в XI ст. У джерелах серед перших згадані Боржавська та Ужанська жупа. Система дворянських комітатів була сформувана на початку XIII ст. Перші пісьмові згадки про комітат (comitatus) Берег датовані 1261 р., а вже у 1299 р. в її управлінні зафіксовано ішпана та 4 справники. Перші відомості ціх інституцій на території Ужанського комітату датуються 1286 р. Виникнення Мараморошського та Угочанського комітатів припадає на значно пізніший час. Вони були «мисливським лісом святих королів», яких володарі залюбки відвідували із-за багатої дичини: король Імре побував тут у 1199 р., а Іштван V - у 1272 р. I якщо їх вабило мисливство, то простий люд цікавила сіль, яку видобували тут ще за часів Римської імперії. На підставі дарчої грамоти короля Іштвана V від 1271 р. можна стверджувати, що Берег та Угоча вже існували в системі комітатів країни. Звісно, кордони Угочанського комітату тоді охоплювали більшу територію, оскільки до неї входив і пізніший Мараморош. Найбільшим землевласником тут залишався король, населення ж складалося переважно 3 прийнятих ним «гостей», котрі займалися передусім землеробством, рибальством, мисливством тощо, і на яких під час перебування короля у комітаті покладалися різні повінності. Важливу роль у формуванні Угочанського комітату відігравали часті відвідини короля Іштвана V (1239-1272), що стало передумовою для створення і облаштування відповідного помешкання для двору. Саме 3 цього «королівський дім» (domus regalis) [14, 45], а також поселення госпесів і виникло Ньолабвар, яке у різних грамотах згодом згадується як Кіральгазо (Королево).

Вже у 1199 р. згадується комітат Мароморош. Відомо із джерел, що король Імре I (1196-1204 рр.) подарував «que noster fidelis iobagio Laurencius comes» («нашому вірному ішпану Леврінцу») 5 aratrum (плуг - одиниця виміру: 1 плуг - 150 королівських гольдів 126,6 га - Авт.) орної землі у озера Ферте, за вірну службу, та що той врятував йому життя «in Maramorisio tempore venationis venatum» («під час полювання у Марамороші»). Більш значне заселення регіону розпочалося після заснування коронних міст. У коло функцій вишківського замку (першого центру комітату) входило захист соляного шляху вздовж річки Тиса. Занепад вишківського замку розпочався після спорудження хустської фортеці. Це повязано з тим, що Тиса, яка постійно змінювала свої береги, послабила позиції лівобережного торгового маршруту. Мараморош відігравав значну роль і в контролі за кордонами сусідніх країн, зокрема Польщі та Молдови. I хоча Карпати були певним географічним бар'єром, численні перевали дозволяли проникнути за територію держави. Угорські королі, засновуючи поселення поблизу кордонів, створювали прикордонні захисні смуги.

Основу економіки в європейських державах становила земля, а також збори й податки, сплачувані особами, котрі на них господарювали. Серед них чільне місце посідали різноманітні місцеві та державні податки. Загальну картину майнових відносин та кількісного складу населення надають різного роду податкові реєстри. Серед основних джерел важливе місце займають так звані «дикальні переписи» (угор. dika) - безпосередній державний військовий податок, запроваджений із середини XIV ст. для населення не дворянського походження. Свою назву він дістав від характеру процесу збору, обсяг якого записували на чотирикутні дерев'яні таблички. Податком обкладали кожен двір, тобто кожні ворота, в які може в'їхати завантажена сіном підвода.

Важливим елементом податкової системи була порта (садиба/обійстя, лат. sessio), або ж земельна ділянка під будинком, за які селянин повинен був платити оброк поміщику та податок державі. Свого часу мірою оподаткування були ворота (угор. kapuadó) [7, 498]. На державному рівні вартість кріпацької садиби було визначено у розмірі 40 золотих 
форинтів. На кінець XVI ст. цей спосіб оподатковування застарів через зростання кількості населення та дрібнення садиб (на одному sessio вже мешкало по кілька сімей). Відтак обчисленні розміру податку на підставі одних тільки воріт вже не відповідало дійсній кількості кріпацьких господарств. Починаючи $з$ цього часу основою королівського податку стало поняття «середньої» порти, це означало 16 будинків - 4 кріпацьких та 12 наймитських господарств $[13,124]$. Під час реєстрації бралися на облік будинки кріпаків та наймитів, а також обійстя, споруджені як «недворянські маєтки», розташовані на земельних ділянках власника населеного пункту, втім будинки одномаєткових (предіальних, від слова preadium - маєток) дворян та розкріпачених, звільнених селян (лібертинів, від лат. libertinus - вільновідпущений). Винятком були лише дворянські обійстя, будинки сільських суддів, шпиталі, корчми (де продавалося вино пана), а також халупки злидарів, що заробляли собі на прожиття жебракуванням. Закон не розпоряджався щодо перепису млинів, парафій, шкіл, пивоварень, лазень тощо, але, як свідчить практика, вони майже звільнялися від податків. У більшості населених пунктів реєстрація обмежувалася тільки переписом будинків кріпаків та наймитів, тут же вказувалося прізвище землевласника.

Свідченням різниці в обчисленні розміру податку може слугувати той факт, що так званий податок 3 «димарів» (тобто податок 3 комина, угор. füstadó) становив 700 тисяч золотих форинтів на рік, і водночас податок із порти складав лишень 200 тисяч форинтів. Розмір податку з порти становив 1,5 форинта на рік, із них 0,5 форинта за кожного наймита виплачував землевласник.

Три важливи переписи, які збереглись, слугують нам основою для дослідження. Перші грунтовні переписи комітатів Угорщини було проведено за часів головного скарбничого Жігмонда Ернуста впродовж 1494-1495 рр [8]. Із досліджуваного періоду збереглися три важливі переписи, що на сьогодні зберігаються в Державному архіві Угорського національного архіву (MNL MOL). Це описи порт (оподаткованих наділів) 1531-1596 рр., пере- пис хат 1598-1608 рр. та порт 1609-1648 рр. Слід зазначити, що перепис порт значно відрізнявся від перепису хат, різниця між даними може коливатися навіть у десять разів. У 1598 р. Державні Збори на законодавчому рівні розпоряджалися стосовно перепису хат. Ініціатива з боку Державних Зборів щодо реєстру не порт, а хат, була обгрунтована передусім тим, що внаслідок 15-річної війни значно зменшилася кількість оподатковуваних наділів [10, 31].

За даними перепису від 1784 р., у середньому по країні в кожному будинку (хаті) мешкали 6,5 осіб; серед рівнинних районів найнижчі показники мав Мукачівський район (5,4 особи). Втім, враховуючи, що в досліджуваний період даною територією не пролягали більш-менш значимі військові шляхи, а також завдавала шкоди турецька навала, щодо комітатів Унг, Берег, Угоча та Мараморош доцільно застосовувати коефіцієнт 7.

У другій половині XV ст. у Березькому комітаті були зареєстровані 145 землевласницьких родин. Багато 3 них були тут корінними ще $з$ часів династії Арпадів, попри це відсів землевласників відбувався постійно. Перший більш-менш точний перепис був проведений у 1549 р. За його даними, у комітаті Берег нараховувалися 1176 порт, що розподілялися між 89 землевласниками: 3 церковні, 1 шпитальний (ордена лицарів Св. Іоанна) - 54, 1 королівський (мукачівський) маєток - 381 обійстя, 59 родин - 741 обійстя [12, с. 175-189].

Розподіл по портам свідчить про те, що лише чверть дворянства розпоряджалася такими статками, що слугували підставою для зарахування їх до категорії заможного або середнього дворянства (bene posessionatus), i вони могли забезпечити собі відповідний рівень життя. За даними перепису, 48 дворянських родин мали по одному обійстю. У комітаті Берег тільки 4 родини (в тому числі королівська домінія) володіли маєтками 3 більш ніж 50 обійстями. Серед великих аристократичних родин варті уваги Баторі, Перені, головнокомандуючий міста Темешвар Іштван Лошонці, але їхня нерухомість була незначною. I навіть обійстя заможніших дворянських родин розподілялися між кількома особами. Так, до прикладу, родина Білкеї, 
маєтки якої були розташовані у верхній частині долини річки Боржава, мала 14 порт, Ілошваї - 39, Лоняї - 50, Перені - 64, Шурані 62 [12, 830-835].

У 1550 році 632 порт Ужанського комітату було зареєстровано за 3 церковними та 44 світськими родинами землевласників: 53 порт перебували у власності церковних землевласників (в т. ч. Лелеська капітула), інші - у світських дворян. Тут розшарування дворянства значно різкіше, ніж у комітаті Берег, оскільки йдеться переважно про дрібнопоміщицькі маєтки, більше того, у 9 випадках це виключно одне обійстя [12, 841-850]. Розподіл порт свідчить і про формування значних суспільних відмінностей. Маєтки 36 родин нараховували менш ніж 5 обійсть, 5 родин мали по 5-10 обійсть, і всього 1 родина належала до категорії заможних або середніх дворян (bene posessionatus), що мали у своїй власності 25-50 обійсть. У комітаті Унг статусом великих землевласників володіли тільки 2 родини: одна 3 них мала 100-200 порт, друга - понад 200. 278,5 обійсть (це 44\%) із загальної кількості обійсть комітату перебували у володінні родини Другетів (Габор, Імре, Антал та Дьордь), котра мала великі маєтки ще й у сусідньому комітаті Земплін $[12,839]$. До числа великих землевласників належала також родина Добо, до якої у спадок перейшла ще й частина статків родини Паловці: вони володіли двома домініями (середнянською та паловецькою), а це 134 порт. В Ужанському комітаті тільки Лелеська капітула та родина Зрітеї мали більш ніж 10 обійсть; менші статки мали також родини Чічері, Дерегнєї, Орос, Чопі, Хелмеці, Корлат, Нейметі, Поладі, Тарновці.

В комітаті Угоча 1549 р. у реєстрі було записано 596 обійсть в 53 населених пунктах. Стосовно Угочанського комітату важливо зазначити, що в його південно-західній частині (Пийтерфолво, Бекень, Форкошфолво, Тіводор) мешкала значна частина дрібного дворянства. Тут також спостерігалося розшарування знаті, оскільки представники баронської гілки родини Перені (Янош та Ференц Перені) володіли 239 обійстями (40\%). 201 маєтності Яноша Перені належали до Ньолабської та Севлюської доміній. Заможними влас- никами були родини Кун (37,4 обійстя), Шурані $(63,6)$, Уйгелі $(49,3)$, але варто відзначити й такі родини, як Баторі, Артанді, Петроваї, Бюді, Ветеші, що мали значні маєтки й у інших комітатах $[12,827]$.

Реєстр комітату Мараморош від 1549 року презентує досить специфічну картину, оскільки саме тут кількість дрібного дворянства $\epsilon$ найвищою у регіоні - загалом 176 родин; вони переважно румунського та русинського походження [12, 468-485]. 3-поміж взятого на облік майна у 810 обійстях найзначнішим $\epsilon$ хустський королівський домен (окрім 5 міст - Хуст, Вишково, Тячів, Довге Поле, Сігет - сюди належали ще й Буштино, Дулово, Теребля, Стеблівка) з його 205,5 обійстями (25\%). Розшарування дворянства тут має найяскравіші ознаки, оскільки 343,3 порт (42,4 \%) перебували у володінні таких дворян, які мали по 1-10 обійсть, а інші 261 обійстя $(32,2 \%)$ належали середнім дворянам.

Упродовж 1576-1596 рр. на досліджуваній території спостерігалося значне скорочення кількості населення: у Березькому комітаті кількість платників податку скоротилася на 22\%, в Ужанському - на 35\%, в Угочанському - на 22\%. Це спричинило зменшення прибутків землевласників. Поясненням цього є передусім воєнні міжусобиці між Угорським королівством і Трансільванським князівством: населення або полягло у боях, або ж, рятуючись від війни, переселилося в інші регіони.

Перепис хат (будинків) 1598 р. порівняно з попередніми даними засвідчив значні зміни у майнових відносинах (за даними реєстрації, проведеної на два роки раніше, коефіцієнт між портами та хатами в Березському комітаті становив 18,5, в Ужанському - 19,6, в Угочанському - 21,8). Відповідно до коефіцієнта обчислення будинок/кількість населення, запровадженим та застосованим Золтаном Давідом, кількість платників податку в Березькому комітаті становила 31353 особи, в Ужанському - 31 689, в Угочанському 15 624, у Марамороському - 7024 особи.

За даними перепису хат від 1598 р. отримуємо наступні дані. Упродовж 1598 р. у Березькому комітаті до реєстру були внесені 4479 хат, із них тільки 191 - майно дрібних 
поміщиків. Найзначнішим, компактним помістям і надалі був колишній королівський маєток у Мукачеві, який, попри численні заборони Державних Зборів, кілька разів віддавали у заставу. У досліджувану епоху власниками заставного маєтку була родина Магочі, з іменами представників якої (Гашпар, Андраш та Ференц Магочі) пов'язується значна кількість заснованих поселень у верхній частині басейну Латориці. На час проведення перепису власником домену був Жігмонд Ракоці [10, 114-116], котрий у 1587 р. одружився із вдовою Андраша Магочі Юдітою Алагі Бекень. Тоді до мукачівського маєтку належали 1988 будинків у містах та селах. Володіння родини Телегді були розподілені між двома маєтками: вдова Пала Телегді володіла 224 будинками у Сентміклоші, вдова Яноша Телегді - 181 у Підгорянах $[10,118]$.

У володінні заможних власників знаходилися наступні маєтки: родина Лоняї (165), родина Ілошваї (147), Мігай Бюді (123), родина Матузнаї (111), родина Даровці (99), Ференц Добов (97), Пал Меліт (94), Габор Шурані (59) [10, 107-119]. Звісно, майно, що ним володіла певна родина, далі роздрібнювалося, адже ним розпоряджалися 2-3 голови родини. Загалом можемо констатувати, що порівняно 3 ономастичними даними значних змін не відбулося, зникли хіба що прізвища Кушаї Якч та Лошонці, а також збільшилися маєтки родин землевласників у верхній частині долини Боржави, а саме Білкеї, Ілошваї, Комловші та Ліпчеї, котрі станом на 1598 р. володіли загалом 221 будинком.

У трьох інших адміністративних одиницях досліджуваного регіону прослідковувалася цікава тенденція: 3 одного боку маєтки сконцентрувалися в руках кількох великих родин, з іншого - у комітаті знаходимо значну кількість дрібних поміщиків, котрі становили відчутну противагу вельможам із значними володіннями.

В Ужанському комітаті контингент маєтків виглядав так: із числа зареєстрованих 4527 будинків 2303 належали дрібнопоміщицьким родинам, над іншими, а це близько половини краю, розпоряджалися практично два сімейства - Другети та Добов. У володіннях Другетів перебували 1540 будинків (Дьордь
Другет - 475, Іштван Другет - 1065), Ференц Добов був власником 567 будинків. Подібна картина відзначалася і в Угочанському комітаті. Тут із внесених у перепис 2232 ділянок під будинками 973 були власністю поміщиків комітату, інші ж розподілялися між родинами Перені (595), Кун (262), Сейкель (232) та Уйгелі (75) [10, 519].

Перепис будинків комітаті Мараморош від 1598 р. не навів даних хустського маєтку (на той час помістя перебувало у розпорядженні казначейства, а за рік король Рудольф I подарував його генералові Джорджо Башті), тож можемо проаналізувати тільки дані дворян жупи. До реєстру були внесені 1006 будинків, втім власність дрібних поміщиків - 556 будинків, зокрема дрібного дворянства: Янош Долгаї (183), Іштван Препоштварі (його батько Балінт Препоштварі дістав частину майна Драгфі як заставу) (65), Іштван Банффі (Ласло Каролі у 1583 р. взяв у заставу за 6000 форинтів бичківський маєток, який успадкували його зяті Іштван Банффі та Мiгаль Ерделі) (50), родина Кун із Рожалю (37), родина Погань (26), Дьордь Корніш (успадкував частину майна родини Долгаї, син Ілони Долгаї та Гашпара Корніша) (28) [10, 223-225].

Саме на цей період припадає і піднесення родини Ліпчеї, укоріненої у Марамороському та Березькому комітатах, члени якої збільшували свої статки частково за рахунок придбання помість, успадкувань, а також заснуванням нових поселень на Верховині. Аналогічний шлях пройшли і дрібнопоміщицькі родини комітату, що відзначилися передусім як посадовці комітату (судді, присяжні). Це родини Бірток та Петроваї зі Сарвасо, Рішко з Кевешлігету (сьогодні Драгово), Білкеї, Стойка, Крічфолві з Білок, Рад та Крічфолуші з Шомошу, маєтки яких мали в середньому по 8-20 обійсть. Найвідомішими представниками тих родин, майно яких нараховувало 1-4 обійстя, були Буд із Будфолво, Ціпле із Фейєрфолво, Гергеш із Сарвасо, Юрко з Калинфолво, Котець із Шайо, Ман із Шайо, Марош із М. Бичкова, Немеш із Калинфолво, Тегзе з Березного, Волаз із Углі, Стан із Алшоврона [10, 223-225].

XVI століття принесло значні зміни у життя пересічного населення регіону Верхів'я 
Тиси. Внаслідок розколу Угорщини на три частини мешканці відчули глибокі зміни в соціально-економічних відносинах, розвиток яких міг відбуватися хіба завдяки прикордонному розташуванню. Окреслені землі, по суті, уникнули турецького нашестя, що, у свою чергу, з урахуванням постійного прибування переселенців, привело до зростання чисельності місцевого населення. Госпітами вважалися рівнинні народи, що прибули сюди, рятуючись від турків, а також слов'яни, що прибували зі сходу від Карпат. Відтак тут не сформувалося класичне вельможне дворянство, серед землевласників заможними вважалися родини з маєтком у 20-30 порт. Аналіз соціально-економічних відносин вказує на те, що лише у деяких маєтках були садиби, більшість селян сплачували податки не грошима, а натуральною рентою, що сповільнювало грошовий товарообіг. 3 огляду на розширення дворянських маєтків, спочатку розміщених лише в долинах річок, важливу роль відігравали заселення, за рахунок яких відбувався не лише приріст населення, а й збільшувалася кількість земель, придатних до сільськогосподарської діяльності. Так сформувалася структура населених пунктів, характерна для сучасної Закарпатської області.

\section{Список використаних джерел}

1. Derzhavnyj arhiv Zakarpats'koyi oblasti - Fond 10: Nadzhupan Berez'koyi zhupy. Op. 1. Od. zb. 107. Knyha reyestraciyi kripakiv i pomishhykiv v selah zhupy 1647-1648 rr., ark. 144.

2. Zubanych L. L. Uchast' dvoryanstva u komitats'komu pravosuddi protyahom XVI-XVIII stolittya. Naukovyj visnyk Uzhhorods'koho universytetu. Ser. Istoriya. Uzhhorod: Vyd-vo UzhNU „Hoverla”, 2012. Vyp. 29. S. 8-12.

3. Zubanych L. L. Formuvannya ta rozvytok suspil'noyi verstvy dvoryanstva u Pivnichno-Shidnij Uhorshhyni v XVI-XVII stolittyax. Naukovyj visnyk Uzhhorods'koho universytetu. Ser. Istoriya. Uzhhorod: Vyd-vo UzhNU „Hoverla”, 2017. Vyp. 1 (36). S. 64-70.

4. Zubanych L. L. Rol' dvoryanstva Zakarpattya i suspil'no-politychnomu zhytti v XVI-XVII stolittyah. Naukovyj visnyk Uzhhorods'koho universytetu. Ser. Istoriya. Uzhhorod: Vyd-vo UzhNU „Hoverla”, 2014. Vyp. 32. S. 3-9.

5. Ezer év törvényei. CompLex Kiadó Kft. 1000 év törvényei internetes adatbázis, 2003. - [Електронний ресурс] // Режим доступу: http://www.1000ev.hu

6. Bereg megye főispánjának iratai 1342-1800. Szerk. Henzsel Ágota. - Nyíregyháza: Szabolcs-Szatmár-Bereg Megyei Önkormányzat Levéltára -Kárpátaljai Állami Levéltár, 1998.110 p.

7. Acsády Ignác. A dicalis összeírások gyűjteménye az országos levéltárban. /I. Acsády. // Magyar Könyvszemle. A Magyar Nemzeti Múzeum könyvtárának közlönye (szerk. Schönherr Gyula). Budapest: 1893. I. évf. 1 sz. 195-2016. pp.

8. Acsády Ignác. Régi magyar birtokviszonyok 1494-1598. // Értekezések a Történelemtudományok Köréből XVI. kötet. Budapest: MTA, 1897. 81-148. pp.

9. Bélay Vilmos. Máramaros megye társadalma és nemzetiségei. A megye betelepülésétől a XVIII. század elejéig. Budapest: Sylvester Nyomda, 1943. $224 \mathrm{p}$

10. Dávid Zoltán. Az 1598. évi házösszeírás. Budapest: Központi Statisztikai Hivatal Levéltára, 2001. 756 p.

11. Lehoczky Tivadar. Beregvármegye monographiája. Ungvár: Pollacsek Miksa Könyvnyomdája, 1881. III. kötet. 860 p.

12. Magyarországi birtokviszonyok a 16. század közepén (szerk. Maksay Ferenc). Budapest: Akadémiai Kiadó, 1990. I-II. kötet. $1110 \mathrm{p}$.

13. Ur és paraszt a magyar élet egységében (Szerk.: Eckhardt Sándor). - Budapest: Budapesti Kir. Magyar Pázmány Péter Tudományegyete, Bölcsészeti Karának Magyarságtudományi Intézete, 1941.222 p

14. Szabó István. Ugocsa megye. Budapest-Ungvár: Hatodik Síp Alapítvány - Új Mandátum Könyvkiadó, 1994. 271.old.

15. Zubánics László. Vitézi végek dicsérete. A nemesség szerepe a XVI-XVIII. századi Északkelet-Magyarország társadalmi fejlődésében. Ungvár-Budapest: Intermix Kiadó, 2016. 292 p.

Зубанич Ласлов. Дворянство северо-восточной Венгрии XVI-XVII вв. - социально-экономический аспект развития

В научной работе изучаем социально-экономическое положение и развитие дворянских семей Северо-Восточной Венгрии (территория современного Закарпатья - комитатов Унг, Берег, Угоча, Мароморош), определены и проанализированы этапы развития дворянства. На основании имеющихся источников стараемся дать новую трактовку исторической роли дворянства в процессах XVI-XVII веков, показать их участия в заселении территории, развития сельского хозяйства, развития общественных отношений.

Ключевые слова: дворянство, комитаты, семья, усадьба, налог, король, грамота, закон.

Zubanych L. The nobility of north-east Hungary in XVI-XVII century - the social-economic aspect of development

The 16th century was a significant turning point in Hungary's development - because of the defeat at Mohách in 1526, and after the Turkish suzerainty of the central part of the country, the counties of the Northern-East Highlands were in the buffer zone of two countries: the Hungarian Kingdom under the rule of 
the Habsburgs and the Transilvanian Principality. The constant danger, the establishment of the system of border fortresses gave a significant value to the social units of military character, which guaranteed the possibility of social advancement into a higher rank - the nobility.

In the statute, on the basis of a study of the database of archival documents ams scientific literature, a comprehensive concrete historical analysis of the place and role of noble families in the socio-political, economic and cultural processes of North-Eastern Hungary (the territory of modern Transcarpathia - countyes Ung, Bereg, Ugocha, Maromorosh) is carried out. It was found out that during the XVI-XVII centuries, four committees of North-Eastern Hungary, within the framework of a unitary state, performed primarily a defensive function, protecting state borders with Poland and Moldova. It has been substantiated that the nobility of Northeastern Hungary thanks to its property status, through the redistribution of power, successfully performed a whole range of tasks, among which the main ones were: preserving the integrity of the state and protecting its borders through the system of frontier castles, as well as supporting the first educational and cultural institutions in their estates. It was found that in the 16th century, with the development of the estate state, the distribution of state power began.

In the scientific work we study the socio-economic status and development of noble families of Northeastern Hungary, the stages of nobility development were determined and analyzed. On the basis of the available sources, we try to give a new interpretation of the historical role of the nobility in the processes of the XVII-XVII centuries, to show their participation in the settlement of the territory, the development of agriculture and social relations.

As the tillable lands create the basis of the management we can see the concentration of the nobility first of all in the plain lands and river valleys. Except the clashes near the borderlines, the area escaped major military operations, and thanks to the colonization, the number of the working-age population grew, and the colonization of uninhabited regions of the Carpathians began.

Key words: nobility, county, family, estate, tax, king, letter, law. 


\title{
Розділ 3 \\ ІСТОРІОГРАФІЯ ТА ДЖЕРЕЛОЗНАВСТВО
}

DOI: 10.33310/2519-2809-2019-47-1-83-87
УДК $94(438) « 1914 / 1918 »: 070-047.44$

\author{
ЕЛЕОНОРА КОВАЧ \\ старший викладач кафедри історії Угорщини та європейської інтеграції, \\ Українсько-угорський навчально-науковий інститут, \\ Ужгородський національний університет, м. Ужгород \\ e-mail: koveleo@gmail.com
}

\section{АНАЛІЗ ПРЕСИ ПРО ОБЛОГУ ФОРТЕЦІ ПШЕМИСЛЬ}

\begin{abstract}
У центрі дослідження є видання «Польова газета», яка видавалась у місті Пшемисль. Більше того, саме «Польова газета», яка публікувалася у місті Пшемисль в період з 4 жовтня 1914 року по 22 березня 1915 року була так званою сполучною ланкою між сто двадцятьма тисячами солдатів, котрі розташовувалися в місті, на захисній лінії як навколо міста так і безпосередньо на передовій. Зокрема, рубрика «Довідка» дозволяла знайомим дізнаватися нові звістки одне про одного. Читачів цікавила інформація про нищівні дії скинутих з російських літаків бомб, про що повідомляли тільки офіційні джерела. Рубрика «Золота книга» містила список солдатів, які розташовувалися в замку і були відзначені за демонстрацію зразкової поведінки.

Ключові слова: Пшемисль, газета, війна, солдат, преса.
\end{abstract}

Видання «Польова газета», що видавалась за період Першої світової війни, публікувала списки охоронців замку Пшемисль [6], які були сприйняті в якості доказової бази військовим керівництвом. Адже безпосередньо перед здачею замку всі офіційні документи були знищені і не залишилися прямі докази подій. Метою створення газети було також збереження військового духу та ентузіазму, про що, зокрема, пише доктор наук, науковець Калман Молнар: «Поява «Польової газети» була виправдана необхідністю інформування солдатів. До оригінального німецького видання, яке спершу базувалося виключно на описі надзвичайних подій, задля інформування близько п'ятдесяти тисячного контингенту угорського війська потрібно було створити нове видання [4]. Видавці успішно долали труднощі (наприклад, відсутність літер з надлітерними знаками) і віднеслись до редагування газети з неабиякою креативністю. Щоденна газета виходила з дозволу командування замку. Вона інформувала про надзвичайні події та актуальний військовий стан.
Також газета містила прогноз погоди, короткі історії про будні солдатського життя (наприклад, звіт про гіркий хліб або історію солдата, який в листі просить від своєї матері гроші і у випадку відмови погрожує духовним переслідуванням після власної смерті), вірші, список нагороджених, військові мотиваційні промови, фінансові звіти та прогнози щодо розвитку військових дій [6].

Дана проблематика в Україні є малодослідженою, зокрема, лише подекуди згадується преса Першої світової війни, втім, спеціальних досліджень не існує. Перш за все відзначимо власне джерела наукового дослідження - видання «Польової газети», які зберігаються в Угорщині у Державній бібліотеці імені Сечені у Будапешті [4]. Закордонні публікації $є$ наявними, наприклад, власне збірка документів, публікацій ії редактора Калмана Молнара [5]. Необхідно відзначити також роботу Яна Асмана [1].

У теоретико-методологічному контексті в роботі, насамперед, використано теорію історичного наративу американського історика 
Гейдена Вайта. В центрі історичної теорії американського історика Гейдена Вайта знаходиться вивчення суті поняття «Історичний наратив» та дослідження його ролі в сучасні історіографії. Сучасні літературні теорії (структуралізм, формалізм) та всі подальші, які частково використовували наратологію довели, що оповідь не тільки є важливим методом та інструментом інтерпретації прозового жанру, але і невід'ємна частина людського світу і самопізнання. Ми оцінюємо наші історії (відображення ситуацій сучасного життя або минулих подій) в контексті наративу перетворюючи їх в цілісне узгоджене оповідання.

Метою дослідження визначаємо аналіз видання «Польова газета», її наратив, структуру видання. Актуальність дослідження визначається як важливістю опрацювання власне документів Першої світової війни в контексті кращого розуміння подій щодення, а також і аналізу культури наративу, культури мислення.

Аналізуючи екземпляри випущені в жовтні 1914 року, можна стверджувати, що кожний номер містив військові репортажі (в рамках цієї рубрики зустрічалися і новини про бої поблизу самого міста Пшемисль), переклад тексту радіоповідомлень отриманих командуванням замку (у випадку його відсутності публікувалася редакційна стаття про хід війни, про шанси на перемогу та про ворога), а також хоча б одна рубрика, яка в більш ширшому розумінні була пов'язана з війною (наприклад, рубрики «Дрібниці» або «Вірш»).

На мій погляд, важливою була присутність рубрики «Огляд преси» тому що вона сприяла об'єктивній зовнішній оцінці подій читачами. Однак, порівняння перекладного угорського варіанту текстів рубрики «Огляду преси» 3 оригінальним іноземним виданням потребує додаткового вивчення. Спираючись на власні дослідження, можу стверджувати, що рубрика «Огляд преси» допомагала розширити кругозір солдатів і дала можливість оцінити події за межами закритої фортеці, та підняти бойовий дух завдяки перекладу публікацій ворожої французької газети, яка писала про героїчні військові вчинки солдатів центральної влади. Видання жовтня одне за одним публікують виключно позитивні військові новини, немає жодної інформації про значні поразки. Військовий дух солдатів, які надсилали вірші був бойовим, а історії рубрики «Дрібниці» висвітлюють військовий героїзм.

Жовтневі номери «Польової газети» функціонували в якості можливого культурного зв'язку з таким мирним періодом в якому ще ні або вже не відбуваються бойові дії і боронячи ворота на батьківщину від військ противника на спину військових не падає відповідальність за захист фортеці, своїх рідних та правителів [6].

Після короткого перегляду власні попередні дослідження стосовно текстів жовтневих випусків «Польової газети», перейду до висвітлення другого пункту, а саме на проблематику концепцій історичного опису. Чи можна вважати історичним описом тексти «Польової газети», або вони залишаються звичайним історичним оповіданням? Для того, щоб дати чітку відповідь на це питання я використовую твердження щодо згаданих термінів американського історика та філософа Гейдена Вайта (1928). Визначення поняття «наратив»: згідно латинської мови «gnaurus» (знати, бути у зв'язку, спеціаліст) та «narro» (розповісти, прив'язати) походять від спільного кореня «gna», що означає знати. Саме Гейден Вайт вперше визначив важливість теорії оповіді в історіографії. В науковій статті, яка аналізує твердження Гейдена Вайта, дізнаємося про те, що в 50-60-их роках XX століття представники англо-саксонської аналітичної історичної філософії та французької структуалістичної прозової поетики також наголошували на факті присутності теорії оповіді в історіографії та на її проблематиці. Серед них були Клод Леві-Строс (1908-2009) - французький антрополог, етнограф та соціолог бельгійського походження та Роланд Барт (1915-1980) - французький філософ, літературознавець та критик. Основним проявом цього явища згідно авторів вище згаданої наукової статті (Томаш Кішонтол, доктор, літературознавець та культуролог; Габор Себерені, науковець) є відхилення історичного твору в результаті присутності теорії оповіді в сторону фікцій та значної вигаданості. 
Зокрема, Вайт вважає, що історик в процесі своєї роботи, ряд подій реконструйованих на основі історичних джерел, перетворює на розповідь. Деталізуючи, історик перетворює ряд звичайних фактів в структуровану лінеарну цілісність, надаючи незначним деталям сенс та вбудовуючи їх у загальну історичну картину. Вайт вважає, що факти описані в джерелах самі по собі не мають значення, а набувають його завдяки історикам і методу імплементації (emplotment) в історичну оповідь. Згідно цього, те що історик називає реконструйованим минулим насправді $€$ сконструйованим, і стає близьким до фікції та до літературного твору. Вайт відокремлює емпіричну (вона доступна тільки для конкретного покоління в конкретний час), пережиту реальність від тієї, що репрезентована в результаті творчої роботи історика. В контексті вищеописаного, виникає питання, чи взагалі потрібний жанр оповіді в історії? Поль Рікер вважає, що так, адже пізнання людського та історичного часу можливе лише скрізь призму оповіді [3].

Підсумовуючи вище згадане, сформулюємо наступну гіпотезу: людина сучасності або дослідник може значно наблизитися до пізнання подій минулого використовуючи ті оповіді, які були створені історіографами на основі історичного джерела або опитування.

Роланд Барт, зокрема, наступним чином формулював визначеня наративу: «...nросто так існує, як життя..є міжнародним явищем переступаючи через культури та історію. Насправді, наратив замість проблеми потрібно сприймати як ключ до вирішення однієї 3 людських проблем, а саме те, як знання перетворити в оповідь, а людський досвід передати в такій формі, яка відповідає більше людській, ніж культурній структурності значення» [2].

Згідно вище процитованої думки, легко можемо дійти висновку, що у випадку рубрики «Військові новини» «Польової газети» текст, що був написаний невідомим автором може вважатися певною зрозумілою та опрацьованою формою людського досвіду у вигляді публіцистичного тексту. Цей текст і $\epsilon$ формою, завдяки чому можливе його переміщення в певну інтерпретаційну призму.
До своїх ранніх думок Гейден Вайт додає: ми не здатні до ідеального сприйняття системи мислення чужих нам людських культур, однак ми досить легко аналізуємо історії, які походять з чужих культур. Питання в тому, чи можемо використовувати цей принцип для сприйняття тексту, який виник більше ніж сто років тому? Ця думки зближує читача 3 поняттям «наративу» стверджуючи його право на існування.

Гейден Вайт згадує приклад Барта, який стверджує що, «наратив» може бути перекладеним без значних смислових втрат, на відміну віршу від або філософського тексту. Ця думка теж тільки підкріплює важливість поняття «наративу». Наратив - це не код, який використовуємо, коли бажаємо надати якомусь досвіду значення. Це така система кодування та взаєморозуміння між людьми, яка забезпечує вільне поширення транс культурних думок про природу спільної реальності, зазначає Гейден Вайт [2].

Вільне поширення транс культурних думок про природу спільної реальності - мабуть, саме цей процес моделює текст рубрики «Військові новини» «Польової газети», тому що він відображав певне відлуння спільно пережитої реальності міського населення (тогочасні читачі військової газети) та солдатів з замку у 1914 році. Всю ту інформацію, яка надходила з зовнішнього світу (вказівки військового штабу) і що сприймали захисники (облогове кільце, атака) [6].

Надалі Вайт підкреслює: серед найповажніших представників сучасної історіографії Якоб Буркгардт (1818-1917), Йохан Хейзинга (1872-1945) та Фернан Бродель (1902-1985), відхилили метод використання наративу, аргументуючи це тим, що події, які вони вивчали не можуть бути описані за допомогою теорії оповіді. Вони відхили думку про опис подій минулого у форматі тексту, де присутні добре розділені частини: вступ, основна частина та завершення, тобто описуючи події та процеси, не використовували інструменти для ототожнення власних робіт з жанром наративу. Згідно цього, вони передали історичну реальність на основі досліджуваних доказів, водночас не використовували форму оповіді. Базуючись на вище описаному, потрібно 
провести чітку межу між історичним оповіданням та наративом, тобто між тими описами, які розповідають події згідно певної ситуативної світової перспективи та тими, що сприймають події як «голос світу», в результаті чого і народжується сама історія [2].

Перша частина останнього речення може використовуватися і до рубрики «Військові новини», тому що в контексті тексту газети, для реального читача 1914 року реальністю було те, що він відчував тоді, а те, про що не знав, зміг прочитати в газеті (наприклад огляд преси з французької газети Le Progres: світогляд військового поета Гейзи Дйоні на основі його віршів, заохочувальні слова правителя, розпорядження командира замку. Другу частину речення теж можна проаналізувати: та тими, що сприймають події як «голос світу», в результаті чого і народжується сама історія. Подібна інтерпретація тексту була б занадто сміливим вчинком.

Наратив тоді стає проблемою, коли ми намагаємося помістити у форму оповіді реальні події та факти. Помістити факти в жанр наративу дуже важко, адже вони постають перед нами не у формі оповіді [2]. Так, на основі думок Буркгардта, Хейзинги та Броделя, Вайт дійшов наступного висновку: «Ми повинні розрізняти історичну оповідь від наративу, тобто розрізняти ті тексти, що розповідають події згідно певної ситуативної світової перспективи та тими, що сприймають події як «голос світу», в результаті чого і народжується сама історія [2].

Отже, ретельніше проаналізую значення наступних речень: «....що розповідають події згідно певної ситуативної світової перспективи...», «...сприймають події як «голос світу», в результаті чого і народжується сама історія...». Згідно цих двох тверджень, намагатимусь оцінити текст рубрики «Військові новини» та віднести його до наративу або до історичної оповіді. Відразу виникає питання: Я сприймаю текст як світову перспективу (у 1914 році вона була сприйнята як реальність в фортеці, що була в облозі)? Згідно цього: особа яка створю- вала рубрику «Військові новини» в 1914 році в оточеній фортеці, на собі відчула реальні події того часу, потім пропустивши їх через власну свідомість, передала власне суб'єктивне бачення того, що відбулося. Після цього читачі (1914 рік) зіткнулися з поданою картиною реальності (на основі цього створили власну картину відчуття реальності).

У порівнянні з цим сучасний читач, який читає електронний цифрований або раритетний випуск «Польової газети» теж зустрінеться з картиною реальності 1914 року. Різниця між двома читачами значна, в першу чергу для сучасного читача події 1914 року вже відносяться до давньої історії, а також відрізняються: вік людей, дати, роки та оточуюче середовище.

Якщо сучасний читач вивчав історію описаних подій будучи школярем, або не в дитячому віці знайшов газети на горищі, то він знатиме і розумітиме кінець та наслідки подій. Тому і по-різному оцінюватиме текст, який в 1914 році теж був сприйнятий солдатом або простим жителем міста. Автор рубрики, редактор газети або її власник теж своєрідним чином оцінювали текст, вважаючи його власним творінням.

Підсумовуючи, зазначимо, що якщо оцінювати аналіз тексту, його зовсім по-різному сприймав читач 1914 року і той, що знайомиться 3 «Польовою газетою» у 2019 році. Історик або науковець використовуватиме текст в якості історичного джерела. В цьому розумінні потрібно чітко відрізнити оцінку та розуміння тексту. Читачі (солдати, та міські жителі 1914 року) сприймають текст як текст. Насправді, текст потрібно оцінювати як набір рефлексій зі сторони авторів тексту або редакторів рубрики. Підсумовуючи вищезазначене, важливо сприймати текст, як світову перспективу (реалії відчуті в 1914 році) та оповідь про побачені події (реальність сприйнята 1914 року). Перспективи подальших досліджень вважаємо здійснити у ракурсі інших джерел, щоденників, які були написані за часів Першої світової війни.

\section{Список використаних джерел}

1. Assmann Jan. A kulturális emlékezet. Írás, emlékezés és politikai identitás a korai magaskultúrákban. Budapest, 1999. 30.old.

2. Hayden White (1997): A történelem terhe. Osiris Kiadó, Budapest. 105-135 old. 
3. Kisantal Tamás-Szeberényi Gábor. Hayden White „hasznáról és káráról”. Narrartológiai kihívás a történetírásban. Elmélet és módszer. http://ru.scribd.com/doc/32450109/Kisantal-Tamas-\%E2\%80\%93-Szeberenyi-Gabor-Hayden-White-hasznaroles-kararol.

4. Molnár Kálmán. Magyar élet és magyar irodalom Przemyslben 1914/1915-ben. Eger, 1924

5. Molnar Kálmán kisebb összegyűjtött cikkei és tanulmányai (II.).Pécs, Dunántúl Pécsi Egyetemi Könyvkiadó és Nyomda Rt., 1933. 20.old.

6. Tábori újság. - 1914, 1.sz. (okt. 4.) -1915, 141.sz. (márc. 22.). - Przemyśl : Rosenfeld M. G., 1914-1915. Országos Széchenyi Könyvtár, FM3 10664.

\section{References}

1. Assmann Jan. A kulturalis emlekezet. Iras, emlekezes es politikai identitas a korai magaskulturakban. Budapest, 1999. 30.old

2. Hayden White. A tortenelem terhe. Osiris Kiado, Budapest, 1997.

3. Kisantal Tamas-Szeberenyi Gabor. Hayden White „hasznáról és kararol”. Narrartologiai kihívas a tortenetírasban. Elmelet és módszer. http://ru.scribd.com/doc/32450109/Kisantal-Tamas-\%E2\%80\%93-Szeberenyi-Gabor-Hayden-White-hasznaroles-kararol.

4. Molnar Kalman. Magyar elet es magyar irodalom Przemyslben 1914/1915-ben. Eger, 1924

5. Molnar Kalman kisebb osszegyujtott cikkei es tanulmanyai (II.).Pecs, Dunantul Pecsi Egyetemi Konyvkiado es Nyomda Rt., 1933. 20.old.

6. Tabori ujsag. 1914, 1.sz. (okt. 4.) -1915, 141.sz. (márc. 22.). Przemyśl : Rosenfeld M. G., 1914-1915. Orszagos Szechenyi Konyvtár, FM3 10664.

\section{Ковач Э. Анализ прессы про осаду крепости Пшемысль}

В центре исследования издание «Полевая газета», которая издавалась в городе Пшемысль. Более того, именно «Полевая газета», которая выходила в городе Пшемысль за период с 4 октября 1914 года по 22 марта 1915 года была связывающим звеном между сто двадиатью тысячами солдат, которые размещались в городе, на линии защиты как вокруг города, так и непосредственно на передовой. Например, рубрика «Справка» позволяла знакомым узнавать новые новости друг про друга. Читателей интересовала информация про сокрушительные действия российских бомб, скинутых с самолетов, о чем информировали только официальные источники. Рубрика «Золотая книга» содержала список солдат, которые находились в замке и были представлены к награде за достойное поведение.

Ключевые слова: Пшемысль, газета, война, солдат, пресса.

\section{Kovach E. Analysis of newspaper articles on the siege of Przemysl fortress}

This article is based on the newspaper of Przemysl. This newspaper was redacting by Kalman Molnar in 1914-1915, after the beginning World War I. In this newspaper we can find poems about the life in the fortress, when the enemy was besiegeing the walls. The prime question is the connection between the Person and the Past (everyday in 1914). The newspaper of Przemysl in this article is a main document of research. This document analyses not only World War I, but the every days of the people.

The history of the World War I. is an important topic for the historians, for the research the reason and the consequence of this occurence. About the reason we can read more, about the consequence too. One of the consequence of World War I. was the foundation of the League of Nations. After the World War I. was founded the new liberalism for analyzing international relations, when it hasn't worked, after the World War II., was founded the neoliberal school for analyzing the international relations. As a historian, we need to know the reasons and the consequences, the meaning the events, we need to know the characteristics of everyday life in the fortress.

Between 4th of October 1914 and 22nd of March 1915 was released in the fortress of Przemysl a newspaper for the soldiers. Its name was „Tábori újság”. It was released on Hungarian language for the Hungarian soldiers, who were protecting the fortress against the Russian army. In this period in the fortress served many thousand Hungarian soldiers. After the defeat they became POWs. The "Tábori Ujság" was one of the most unical war-newspapers during the World War I. w It was written in Hungarian language; it was released during the assault; it was useful for many thousand soldiers, because they wanted to know about the life outside of the fortress; they've got information about the hero of the month; who could got medal for his heroism etc. In the column of Golden Book has published the names of decorated solders, and it was an evidence after the war, because every official documents were annihilated before the surrender of fortress.

Key words: Przemysl, newspaper, war, soldier, collective memory. 
DOI: 10.33310/2519-2809-2019-47-1-88-94

УДК 94 (=411.16) «1881/1914»: 930

\author{
МАРІАННА ЛАСІНСЬКА \\ кандидат історичних наук, доцент кафедри історії, \\ Миколаївського національного університету імені В. О. Сухомлинського, \\ м. Миколаїв, Україна \\ e-mail: mariannalasinska@gmail.com
}

\title{
ДЖЕРЕЛА 3 ВИВЧЕННЯ МІЖНАРОДНИХ ТА МІЖКОНТИНЕНТАЛЬНИХ МІГРАЦІЙ ЄВРЕЙСЬКОГО НАСЕЛЕННЯ КІНЦЯ ХІХ - ПОЧАТКУ ХХ СТОЛІТТЯ
}

\begin{abstract}
Анотація статті. В статті наведено стислу характеристику архівних установ та груп джерел з історії міжнародних та міжконтинентальних міграцій єврейського населення впродовж 1891-1914 років. Подано опис джерел, що містять інформацію про причини, передумови й обставини переселення юдеїв з країн Східної та Західної Європи, з фондів Центрального архіву історії єврейського народу (Держава Ізраїль). Висвітлено групи джерел, котрі є ключовими для дослідження історії репатріації єврейського населення з різних країн світу до Палестини в означений період, 3 колекцій Центрального сіоністського архіву (Держава Ізраїль). Охарактеризовано джерельну базу з історії міжконтинентальних єврейських міграцій з Європи до краӥн, переважно, Північноамериканського континенту, що міститься в фондах Національної бібліотеки Ізраїлю (Держава Ізраїль).

Ключові слова: джерела, євреї-переселенці, Перша та Друга алія, архіви, міжконтинентальні та міжнародні мігращії.
\end{abstract}

Єврейські міграції 1881-1914 років стали одним 3 наймасштабніших в історії людства процесом переміщення значних груп населення на інші континенти, що значно вплинуло на подальший економічний, політичний, культурний розвиток країн, як донорів так і реципієнтів. При цьому, європейські держави та Російська Імперія стали постачальниками людського ресурсу для країн Північного і Південного Американських континентів, Палестини, Південної Африки, Австралії тощо. Результатом означених процесів стало накопичення значної джерельної бази з історії єврейських міжнародних та міжконтинентальних міграцій наприкінці XIX - на початку XX століття. Мова йде про потужний масив документальних джерел (закони, діловодні документи вищих та місцевих органів влади, статистичні матеріали Російської, Оманської, Австро-Угорської імперій, Англії, Сполучених Штатів Америки, Канади, Аргентини, Мексики, Бразилії, Японії, Австралії тощо); наративних джерел; періодичної преси. Матеріалів комісій у справах євреївпереселенців; документів про натуралізацію і оподаткування; епістолярних джерел (листування чиновників різного рівня, з правових питань щодо емігрантів; листування самих переселенців тощо); паспортів і білетів; прикордонних пропускних пунктів та портових реєстрів мігруючих; реєстрів державних організацій у справі міграційної політики; документів благодійних єврейських організацій; метричних книг; статистичних відомостей; особових справ; джерел особового походження тощо. Найважливішими були документи фондів: Центрального сіоністського архіву, Центрального архіву історії єврейського народу, Національної бібліотеки Ізраїлю, Державного архіву Київської області, Державного архіву Одеської області, Державного архіву Миколаївської області, Російського державного архіву соціально-політичної історії (Архів Бунда та організацій ПоалейЦіон в СРСР), Російського державного історичного архіву, Landsmanshaftn (архівів земляцтв єврейських переселенців в місті НьюЙорк), Ellis Island (архів індивідуальних даних переселенців), електронних мап (місць здійснення єврейських погромів, компактного розселення переселенців тощо), інших джерел. Вивчення вищезазначених груп 
джерел може послужитися не лише в справі детальної реконструкції історії єврейських міжнародних та міжконтинентальних міграцій 1881-1914 років, але й стати в нагоді вченим, що займаються студіюванням проблеми визначення кількості жертв геноцидів першої половини XX століття на території Східної Європи та дослідникам єврейської генеалогії.

Серед науковців, котрі в тій чи іншій мірі торкались питання студіювання джерельної бази означеного питання, виділено наступних: Дж. Рутер надрукувала в 1994 році книгу «Єврейські міграції», що демонструє карту світу з нанесеними на ній районами проживання єврейської діаспори та міграційними потоками; Обра Н. Ньюман, Николас Дж. Еванс, Дж. Грехам Сміт, Шауль В. Ізров в 2006 році опублікували грунтовну збірку наукових нарисів «Єврейські міграції до Південної Африки. Записи тимчасового притулку для бідних євреїв 1885-1914» на підставі аналізу нових, ще жодного разу не публікованих оригінальних архівних матеріалів; Г. Елрой провів важливі дослідження історіографії та джерелознавчої бази історії єврейських міграцій, опублікувавши їх результати в 2014 році в книзі «На необіцяній землі: єврейська міграція до Палестини на початку XX століття»; Дж. Джордан, Л. Лев, Дж. Шльор в 2016 році в Нью-Йорку опублікували книгу «Єврейські міграції та архіви», що містить наукові статті на тему дослідження сімейних епістолярних архівів емігрантів, мемуарів, особистих речей євреїв-переселенців; Ю. Шнайдавінд в 2018 році опублікувала матеріали на основі архівних даних «Ашкенази переселяються - німецько-єврейська імміграція до Австралії впродовж XIX століття»; роботи Джона Д. Клера одного з провідних дослідників єврейських міжконтинентальних міграцій; джерелознавчі статті наукового співробітника Інституту вивчення єврейської діаспори при Петербурзькому інституті юдаїки А. I. Хаєши; роботи Я Шпитцера по аналізу архівних та електронних джерельних баз з історії єврейських міграцій для встановлення дійсних причин масового виїзду євреїв з Російської імперії до Америки, серед котрих, автор намагається виключити погроми, як основний мотивуючий фактор для переїзду.
Не зважаючи на високий рівень інтересу в світі до важливої проблеми джерелознавчої бази з історії єврейських міграцій у 18811914 роках, в Україні ця тема жодного разу не ставала предметом спеціального наукового інтересу істориків. Попри той факт, що значна частина емігрантів була вихідцями саме 3 українських земель, а наслідки міграційних процесів були значними для нашої країни, в тому числі. На ліквідацію означеної лакуни спрямовано дане дослідження.

Стаття $є$ однією 3 циклу робіт авторки, присвячених розробці джерелознавчих питань історії переселення єврейського населення. Основним їі завданням є визначення місць зберігання та стисла характеристика груп джерел з історії єврейських міжнародних та міжконтинентальних міграцій наприкінці XIX - на початку XX століття.

Найбільшу колекцію архівних матеріалів 3 історії єврейських міграцій знаходимо в сховищах Центрального сіоністського архіву та Центрального архіву історії єврейського народу. Документи зібрані зі всього світу на багатьох мовах (їдиш, іврит, німецька, англійська, французька, іспанська, польська, руська, українська, білоруська, литовська, турецька тощо). Ретельно відцифровані мільйони паперів, візуальних матеріалів (негативів, фотографій, мап, статей, плакатів тощо), аудіо записів на яких зафіксовані важливі для сіоністських рухів і створення Держави Ізраїль голоси та розмови. Тут, також, зберігаються книжки, періодика, пов'язана з історією сіоністського руху та міжконтинентальних міграцій. Зазначимо, що міграційні процеси кінця XIX - початку XX століття мали виняткове історико-політичне значення для кількох країн світу, справили вплив на них, а також на створення Держави Ізраїль.

Інтерес серед справ Центрального архіву історії єврейського народу викликають теки з інформацією про створені по всьому світі сіоністські гуртки та організації. Програмні документи таких осередків, протоколи їх засідань, списки учасників, фінансові звіти про діяльність та надану допомогу бажаючим переїхати до Палестини. Справи заведені поліцією, чи судові справи яким підлягали сіоністи, де зазначалась причина затримання та 
міра покарання. Про висилку за кордон євреїв-іноземців. Контроль за перебуванням євреїв виключно у місцях з дозволом на розселення та покарання для тих, хто не мав у своїх документах дозволу перебування поза «межею осілості». Контроль за тим, щоб ремісники і торгівці займались виключно дозволеними їм справами. Справи заведені поліцмейстерами на іноземних рабинів, що прибували з-за кордону з релігійною метою. Багатьох з них визнавали за шпигунів. Фонди містять доповідні записки Міністерства внутрішніх справ Російської імперії про знищення посилок, які надсилалися євреям «межі осілості» 3-за кордону. Доноси на імена губернаторів про провини євреїв (в тому числі за провину визнавалося не шанобливе висловлювання в бік православної церкви, статеві стосунки євреїв 3 християнами тощо) містять докладну інформацію стосовно побуту єврейських общин Російської імперії, переміщення юдеїв в межах імперії та поза ними. Листи. Матеріали про погроми. Справи про діяльність благодійних єврейських організацій. Всі ці документи яскраво ілюструють комплекс причин, передумов та обставин початку потужного руху переселення єврейського населення країн Східної та Західної Європи на інші континенти.

Сховища Центрального сіоністського архіву містять матеріали, пов'язані з різними аспектами і проявами сіоністських рухів. Копії переліків репатріантів, що прибули до Ізраїлю з 1919 до 1968 року. Особові справи видатних сіоністів. Численні листи містять інформацію обговорення діяльності сіоністів. Мемуари. Протоколи та рішення сіоністських організацій і єврейського населення в Палестині, у всіх його варіаціях і формах. Серед фондів архіву маємо зазначити: особовий фонд T. Герцля; фонди сіоністських інституцій (Всесвітньої сіоністської організації, Єврейського агентства, Єврейського національного фонду, Фонду Керен га-Єсод і сіоністських конгресів); фонди установ єврейського населення Палестини до заснування Держави Ізраїль (архіви Національної ради, архіви Палестинської асоціації єврейської колонізації, архіви медичної організації Хадасса та ін.); персональні фонди видатних діячів сіоністсь- кого руху (Н. Сколов, Д. Волфсон, М. Боденхеймер та ін.); фонд фотографій містить 1 мільйон фото і негативів, що зображують життя на землях Ізраїлю та діяльності сіоністів в країнах розселення діаспори 3 1890 до 1990 року; фонд колекції мап та планів містить понад 130 тисяч одиниць; колекція зображувальних джерел розподіляється на плакати та повідомлення і рекламні листи, які друкувались починаючи з 1920 року; колекція історіографічних джерел містить понад 140 тисяч примірників, котрі зберігаються в бібліотеці архіву; фонд зберігання періодичної преси містить газети різними мовами за період з XIX століття; фонд мікрофільмів містить відфільмовані колекції документів, оригінали котрих знаходяться в архівних установах інших країн (Росія, США, Австрія, Великобританія, Голландія, Угорщина, Чехія, Франція, Канада); колекція аудіо записів містить понад 3,5 тисячі одиниць; колекція матеріальних джерел містить близько 1550 найменувань, що становлять предмети мистецтва, збірки медалей та нагород тощо. Фонди Центрального сіоністського архіву $\epsilon$ найбільшим сховищем світу для різних груп джерел з історії єврейських міграційних рухів спрямованих з різних держав до Палестини.

Значна кількість джерел зберігається в Національній бібліотеці Ізраїлю, котра $\epsilon$ найбільшою бібліотечною установою в Державі Ізраїль та зберігає у своїх книгосховищах понад 4 мільйона одиниць. Величезна кількість книг, рідкісних джерел особового походження, образотворчих джерел, зокрема, колекцію цінних фотографій, історичних плакатів, особистих та інституціональних архівів, та джерел єврейського і ізраїльського мистецтва у вигляді аудіо та відео. Певна кількість матеріалів бібліотеки доступна її користувачам на офіційному сайті.

Національна бібліотека Ізраїлю займається збиранням колекцій джерел різного характеру, їх систематизацією та публікацією для широких кіл громадськості на своєму сайті. Сьогодні цифрові технології охоплюють всі сфери людського життя, значно розширюючи можливості дослідника в процесі збору матеріалів. Використання методу дигіталізації набуває розповсюдження при виконанні історичних 
досліджень. Відцифровані і викладені до мережі інтернет, як цілими установами, так і окремими користувачами великі обсяги текстів, графічних фото- зображень, аудіо- та відеозаписів, котрі мають значення першоджерел. Звісно, їх достовірність, репрезентативність і повноту необхідно перевіряти. В тім, науковому загалу тепер стали доступними джерела, нові, раніше не вивчені та не публіковані, зокрема такі, що носять характер особового походження, образотворчі джерела та багато інших. Офіційні й неофіційні сайти наукових, освітніх і культурних установ, організацій та об'єднань, соціальні мережі, тематичні блоги й форуми стали місцем, де історики, краєзнавці можуть знайти зображення вже не існуючих архітектурних пам'яток, зокрема зруйнованих синагог, шкіл, будівель громадського призначення та, просто, єврейських будинків тощо; втрачених культурних і релігійних цінностей; подій, що мали значення для єврейського соціуму, зокрема, свят; окремих людей, їх родин, колективів і т.ін. Все це розширює уявлення, допомагає досліднику глибше вивчити історичні обставини, культурні традиції часу, деталізувати дослідження і персоніфікувати його.

При вивченні історії єврейських міжконтинентальних міграцій наприкінці XIX - на початку XX століття важливим бачиться використання образотворчих джерел, фотокарток та листівок. Вони, як найкраще зафіксували, зберегли, відправлені з Європи зображення «старого життя» єврейських кварталів та містечок, котрих вже більше не існує, та надіслані з Америки, у зворотному напрямку, - зображення побуту євреїв-емігрантів. Зауважимо, стосовно фото, котрі відправляли емігранти до місць свого народження, часто на них позували в одязі взятому на прокат, або придбаному для якогось особливого випадку у фотоательє, з бутафорськими меблями, чи на фоні визначної архітектурної споруди, тому в якості окремих самостійних джерел, особливо коли на них відсутні ідентифікуючі підписи, вони є мало інформативними. Листівки могли бути зробленими у вигляді фотокарток, мальовані художниками в майстернях, або нарисовані від руки. Особливе інформативне значення несуть написи розмі- щені на листівках, котрі часто містять привітання 3 єврейським новим роком Рош хаШана та іншими святами, в більшості на їдиш, дати, імена, короткі описи подій. Важко визначити, що $є$ більш значимим в подібних джерелах, естетична чи їх пізнавальна цінність.

Рятуючись від погромів і переслідувань, на зламі XIX-XX століть, євреї зі Східної Європи масово емігрували до США. В результаті переїзду на інший континент, люди втрачали общинні та, інколи, родинні зв'язки, забували єврейські звичаї, традицію і мову. На теренах же самої Східної Європи фактори національної і культурної самобутності єврейського етносу методично винищувались радянським та нацистським режимами в першій половині $\mathrm{XX}$ століття. Тому, в деяких випадках фотокартки та листівки, котрими вітали євреї через океан родичів і друзів з найбільшими святами - своєрідний «привіт» 3 минулого. На зображеннях, які вже стали документами своєї епохи, що несуть достовірну інформацію (особливо, якщо це фото) та відсилалися 3 Північноамериканського континенту знаходимо не лише сцени зі щоденного життя емігрантів, але приклади їдишського гумору, анекдотів. Цікавим прикладом збережених листівок 3 родинних колекцій емігрантів $\epsilon$ мальовані зображення Землі обітованої.

Значною колекцією листівок кінця XIX початку XX століття, на яких змальовано моменти 3 життя євреїв емігрантів володіє Національна бібліотека Ізраїлю та Науководослідний центр фольклору Єврейського університету в Єрусалимі. На базі Національної бібліотеки Ізраїлю 17-19 березня 2019 року пройшов Глобальний форум, присвячений темі «Міграції-кордони-ідентичність», в результаті роботи котрого, широкому загалу дослідників стали доступні відцифровані в гарній якості листівки з вищезазначених колекцій. Проект Національної бібліотеки Ізраїлю «Час подорожі», присвячений збору та скануванню ізраїльських і єврейських листівок, щоб зробити їх доступними для широкої громадськості. 3 аналогічною метою, співробітниками установи було створено публічну групу в соціальній мережі Face Book «Life before the Holocaust», де євреї, що пережили 
Голокост, їх нащадки, або вцілілі родичі жертв Катастрофи (Шоа) розміщують фото та відеоматеріали, листівки, епістолярні джерела з особистих родинних архівів тощо.

До колекції Національної бібліотеки Ізраїлю, також, входять зібрання мініатюрних молитовних книжок. Ці видання за задумом проектувальників мали достатньо компактні розміри (менше за кулак) для розміщення в кишені мандрівника-емігранта та мінімальну вагу, щоб їх можна було взяти з собою під час подорожі через море. Типографії, на зразок німецького видавництва С. Б. Гусдорфера та Зерндорфера і Соммера ще з середини XIX століття спеціально почали випускати молитовні книги (сидури) для від'їжджаючих за кордон євреїв, щоб ті могли здійснювати молитви щодня (сидури містили усі необхідні молитви на кожен день року). На титульній сторінці сидура, зазвичай, зазначалося «Молитви на весь рік, для тих, хто їде в дорогу, і тих, хто перетинає море, і для тих, хто їде до країни Америки» на їдиш. Книги містили повсякденні молитовні служби, а, також, молитви у Шаббат, різні свята i, звичайно, подорожню молитву, прохання, яке читають мандрівники, що вирушають у довгу подорож. Подібні книги були дуже популярними і розповсюдженими. Цей факт підтверджується їх перевиданням, що здійснювалось декілька разів протягом багатьох років. В Національній бібліотеці Ізраїлю зберігаються копії, надруковані в 1842, 1854 та 1860 роках. Не зважаючи, на значну кількість тиражів молитовних книг, через щоденне використання подібних видань, особливо в умовах подорожі, негативного впливу зовнішніх факторів на їх збереженість, до наших днів дійшли лише одиничні примірники з них.

Ще однією групою джерел, котрі входять до колекції Національної бібліотеки Ізраїлю $€$ епістолярні пам'ятки. Зокрема, тут зберігаються і відцифровані листи емігрантів, котрі місять вкрай важливу, докладну інформацію, про: причини переїзду єврейського населення Європи на інші континенти; міграційні маршрути, які подекуди були звивисті, через інші країни або, навіть, континенти, перш ніж євреї-емігранти діставались остаточного пункту прибуття; складнощі які поставали на їх шляху, проблеми з отриманням «закордонного паспорту», дозволу на виїзд/в'їзд, обміном грошей, зневажливе ставлення урядів та населення транзитарних країн, жахливі умови морської подорожі; а також, про два характери єврейських міграції, економічний, котрий спрямовував емігрантів до Америки та ідеологічний, або релігійний - до Палестини. Листи емігрантів $\epsilon$ важливою групою джерел, через зазначення міста виїзду та імен родичів, що лишились в рідному містечку, що стає в нагоді сучасним дослідникам єврейської генеалогії та історії Катастрофи (Шоа).

Втім, найбільшу частину джерел, що входять до колекції Національної бібліотеки Ізраїлю становлять історіографічні джерела. Тут зберігаються книги різними мовами (іврит, ідиш, німецька, англійська, польська, російська тощо), які висвітлюють коло проблем пов'язаних з історією єврейських міжконтинентальних міграцій XIX-XX століть і почали виходити друком майже одночасно 3 першою алією та продовжують надходити до бібліотечних фондів у вигляді публікацій найновітніших результатів досліджень 3 означеної проблеми до сьогодні. В них підіймаються питання: причин масового виїзду єврейського населення зі Східної Європи протягом кінця XIX - початку XX століття, серед яких вказуються антисемітизм, утиски політичні, економічні, правові, погроми, війни тощо; напрямків та потоків єврейських міграцій: до країн Північної та Південної Америки, Палестини, Африки, Австралії, Англії, Індії, Японії, Китаю і т.ін.; допомоги євреямпереселенцям: дії величезної кількості міжнародних благодійних та громадських організацій, фондів, комітетів, індивідуальних меценатів та заможних єврейських родин; питання створення власної держави для єврейських переселенців; збагачення країн, що приймали євреїв їх культурою, освітніми, науковими здобутками в різних галузях; важкі умови, що супроводжували сам переїзд та перші десятиліття перебування емігрантів на чужині; стосунки з місцевим християнським населенням країн-реципієнтів; ступінь інтеграції єврейського населення до нового соціального середовища. Окремо відзначимо видання, що стосуються публікації архівних 
матеріалів з різних країн світу та джерел особового походження, котрі розкривають історію єврейських міжконтинентальних міграцій наприкінці XIX - на початку XX століття, історіографічні роботи та рідкісні видання періоду XIX - початку XX століття, котрі містять унікальну інформацію і носять характер першоджерела.

Використання всієї сукупності джерел, що зберігаються у фондах Центрального архі- ву історії єврейського народу, Центрального сіоністського архіву, Національної бібліотеки Ізраїлю домагає відтворити та проаналізувати, як найповніше складні процеси єврейських міжконтинентальних міграцій кінця XIX початку XX століття та вимагає подальшого вивчення і розширення спектру тематик, пов'язаних з аналізом джерельної бази з історії переселення єврейського населення впродовж 1891-1914 років.

\section{Список використаних джерел}

1. Alroey G. An unpromising Land: Jewish migration to Palestine in the early twentieth century. Stanford, California: Stanford University Press, 2014. P. 1-20.

2. Benjamin Ben M. The Jewish Question. Its sure, easy, and immediate solution. Manchester, 1909. 9 p.

3. Jewish migration to South Africa: The records of the Poor Jews' Temporary Shelter, 1885-1914 / edited by Aubrey N. Newman, Nicolas J. Evans, J. Graham Smith, Saul W. Issroff. London: Courtesy of the Jewish Museum, 2006. 500 p.

4. Jewish Territorial Organization: Reference by the British Sectional council to the Geographical commission. London Offices: 15 Essex Street, Strand, W. C. 1907. 200 p.

5. Jordan J., Leff L., Schlor J. Jewish migration and the archive. New York: Laylor \& Francis, 2016.

6. Lestchinsky J. Jewish migration for the past hundred years. New York: Yiddish scientific institute - Yivo, 1944.

7. Meltzer M. Taking root. Jewish Immigrants in America / Milton Meltzer. - New York: Ferrar, Straus and Giroux, 1976.

8. Memorandum. Freeland League for Jewish territorial colonization for the consideration of the delegates at the international refugees conference at Evian. London, 1938.7 p.

9. Parkers J.W. How Russian Jews came to the West. Toronto, Canada: The Committee on Jewish-Gentile Relationships, 1938.16 p.

10. Schneidawind J. Ashkenaz Down Under-German-Jewish Immigration to Australia during the Long Nineteenth Century. The 2018 Annual Conference of the Centre of Excellence in Estonian Studies On the move: migration and diasporas. Nov 29 - Dec 01 2018. Estonian Literary Museum, Tartu, Estonia. Abstracts. ELM Scholarly Press Tartu 2018. P. 43-44.

11. Rutter J. Jewish migrations / Jill Rutter. - Hove, East Sussex: Wayland, 1994. - 48 p. - ill.

12. Spitzer Y. Pogroms, Networks, and Migration. The Jewish Migration from the Russian Empire to the United States 1881-1914. September 17. 2013. Електронний ресурс. Режим доступу. https://docviewer.yandex.ua/view/0/?page= 1\&*= XhD5aLDDzhVU16R19iBpASAumo97InVybCI6Imh0dHBzOi8vZWgubmV0L2Vo YS93cC1jb250ZW50L3VwbG9hZHMvMjAxMy8xMS9TcGl0emVyLnBkZiIsInRpdGxIIjoiU3BpdHplci5wZGYiLCJub2lmcmFtZSI6dHJ1ZSwidWlkIjoiMCIsInRzIjoxNTU5NDg wNzE1MTAyLCJ5dSI6IjM3MDcyNzI1NjE1MzE20DE10DAiLCJzZXJwUGFyYW1zIjoibGFuZz1lbiZ0bT0xNTU5NDgwNzAzJnRsZ D11YSZuYW1IPVNwaXR6ZXIucGRmJnRleHQ9T3ZlcithK3NpbmxlK2dlbmVyYXRpb24lMkMrbW9yZSt0aGFuK2ErcXVhcnRlcit vZitqZXdpc2gtcnVzc2lhbitwb3B1bGF0aW9uK3dhcytyZXNldHRsZWQmdXJsPWh0dHBzJTNBLy9laC5uZXQvZWhhL3dwLWNv bnRlbnQvdXBsb2Fkcy8yMDEzLzExL1NwaXR6ZXIucGRmJmxyPTE00CZtaW1IPXBkZiZsMTBuPXJ1JnNpZ249YTcwMmNIZmZl NmY5YzI4NDNmMWUyZTk5Yzk1YTM3ZTYma2V5bm89MCJ9\&lang=en.

13. The Rare Books That Kept Prayer Alive During the Jewish Migrations of the 19th Century. Електронний ресурс. Режим доступу. https://blog.nli.org.il/en/mini_siddur/?utm_source=activetrail\&utm_medium=email\&utm_campaign=\%20Eng lish\%20Newsletter\%2014.03.2019\&_atscid=3_2269_160087254_9789662_0_Tzwttadxfddchhups2p.

14. Zangwill I. Jewish Territorial Organization: Be fruitful and multiply. Headquarters, Rings Chambers, Portugal Street, Lond on, W.C. $1909.24 \mathrm{p}$.

Ласинская М. Источники к изучению международных и межконтинентальных миграций еврейского населения конец XIX - начало XX века

В статье приведена краткая характеристика архивных учреждений и групп источников по истории международных и межконтинентальных миграций еврейского населения 1891-1914 годов. Дано описание источников, содержащих информацию о причинах, предпосылках и обстоятельства переселения иудеев из стран Восточной и Западной Европы, из фондов Центрального архива истории еврейского народа (Государство Израиль). Указаны группы источников, которые являются ключевыми для исследования истории репатриации еврейского населения из разных стран мира в Палестину в указанный период, из коллекций Центрального сионистского архива (Государство Израиль). Охарактеризована источниковая база по истории межконтинентальных еврейских миграций из Европы в страны, преимущественно, Североамериканского континента, хранящаяся в фондах Национальной библиотеки Израиля (Государство Израиль).

Ключевые слова: источники, евреи-переселенцы, Первая и Вторая алия, архивы, межконтинентальные и международные миграции.

Lasinska M. The Sources for studying of international and intercontinental migrations of jewish population in late XIXth - early XXth century

Jewish intercontinental and international migrations in the 1881-1914 were one of the most important and intense mass population movements in history. Over a single generation, large number of European 
Jews was resettled overseas. The main reasons of this process were cases of anti-Jewish mob violence. The result of Jewish migration is in global changes of economic, political, cultural situation in many countries of the World and in State of Israel foundation.

Short review of collections of documents, personal papers, epistolary, memoirs, postcards, photograph, maps, plans, graphics, artifacts, microfilms, audio, newspapers and historiographical sources about history of Jewish intercontinental migrations during the end of XIXth - earlier XXth century are present in this article. Most of which are hold in the National library of Israel, Central Zionist Archive and The Central Archives for the History of the Jewish People funds.

The aim of this work is characterized groups of historical sources about intercontinental Jewish migrations at the end of nineteenth - early twentieth century and in consciousness of their significance and role for the economic, political, cultural, social development of certain regions that have become objects of intercontinental migrations. Feasible task assignments of this work: to learn the main collections of archival sources that contain the deliberations, memoirs, correspondence, minutes and decisions, of the Jewish migration's movements; to learn the status of Jews at the end of the nineteenth and start of the twentieth century in depending upon their location; to learn the main cause and effect of Jewish intercontinental migrations; etc.

A vast part of archival sources has now become available for anyone attempting to write a history of Jewish intercontinental migrations over the last two hundred years in archival and library collections of Israel. Such as: Libraries \& Databases of the Hebrew University of Jerusalem, the National Library of Israel, Central Zionist Archive and The Central Archives for the History of the Jewish People Jerusalem, which hold the archives of hundreds of Jewish communities from over the world.

Keywords: Jewish settlers, First and Second Aliyah, bibliography, intercontinental and international migration. 
DOI: 10.33310/2519-2809-2019-47-1-95-97

УДК 94 (477). «1919»

\author{
ВЛАДИСЛАВ ПАРХОМЕНКО \\ доктор історичних наук, професор кафедри історії \\ Миколаївського національного університету імені В. О. Сухомлинського \\ м. Миколаїв, Україна \\ e-mail: vlad10031974@gmail.com
}

\title{
ІСТОРИКО-МЕМУАРНА СПАДЩИНА Л. ЧИКАЛЕНКА ПРО ПОДІЇ 1919 р. В УКРАЇНІ
}

\footnotetext{
У статті на підставі спогадів громадського діяча Л. Чикаленка висвітлено події Української революції у 1919 р. Розповідається про втрату військами Директорії Києва, зустрічах мемуариста з Є. Петрушевичем та С. Петлюрою, переговори з представниками Дону та Кубані.

Ключові слова: Чикаленко, мемуари, Директорія, Українська революція.
}

У 2019 році відзначаються 100-роковини подій Української революції, зокрема проголошення акту Соборності та періоду Директорії УНР. Важливе місце при дослідженні та висвітленні тих визначальних подій посідають мемуарні свідчення сучасників. Серед численної мемуарної літератури про цю добу зокрема таких діячів, як голови Директорії В. Винниченка, прем'єр-міністрів Б. Мартоса та I. Мазепи, військових О. Греківа та М. Омеляновича-Павленка, значне місце посідають і спогади Л. Чикаленка. Народився Лев Євгенович Чикаленко (1888-1965) в родині українського громадського діяча Є. Чикаленка, був секретарем Центральної Ради, співпрацював в Українській Академії наук, після поразки визвольної боротьби, опинився в еміграції. У 1963 році в Нью-Йорку опубліковано його спогади про визвольні змагання 19191920 рр. [1]. Потім їх перевидано вже в незалежній Україні київським видавництвом «Темпора» в 2011 р. [2].

Свої спогади Л. Чикаленко розпочинає 3 30 серпня 1919 р., тобто з дня здобуття армією Директорії УНР Києва. Мемуарист який тоді проживав у місті, згадував, що кияни були здивовані побачивши на вулицях республіканські війська в австрійській уніформі, адже це були галицькі підрозділи збройних сил Директорії під командуванням генерала А. Кравса [1, с. 5]. Несподівано для всіх, наступного дня, через Ланцюговий міст до Києва увійшли білогвардійські частини Доброволь- чої армії А. Денікіна. Між українським і білогвардійським командуваннями виник конфлікт, що призвело до втрати Директорією Києва. Галицький генерал А. Кравс погодився на вимогу білогвардійців, і відвів свої війська на 25 км, на захід, від Києва. Серед українського війська відразу поширилися невдоволення та чутки про «зраду» галичан.

Ця подія знайшла значний відгук в мемуарній літературі. Так, очільник Директорії В. Винниченко відзначав, що існував наказ Головного отамана С. Петлюри не вступати в збройні сутички з білогвардійцями, відповідно галицький генерал А. Кравс, війська якого зайняли Київ, його лише виконав [3, с. 448449]. Аналогічно пояснював причини відведення військ УНР із міста і генерал М. Омелянович-Павленко, вказуючи на розпорядження уникати боїв із армією Денікіна $[4$, c. 196]. I. Мазепа наголошував на тому, що галицькі військові були недостатньо політично підготовлені та незнали реалій життя Наддніпрянської України. На його думку, висловлену в спогадах, шанси укріпитися в Києві були, враховуючи незначну кількість білогвардійського загону, що увійшов у місто. Однак А. Кравс не прийняв бою через те, що не вбачав у денікінцях ворогів, а розглядав їх швидше, як союзника проти більшовиків [5, с. 259]. Серед деяких лідерів УНР також були сподівання про встановлення «демаркаційної» лінії по Дніпру з Добровольчою армією. 
Проте лідери 30УНР і галицьке командування, навпаки, у всьому звинуватили керівництво Директорії. 9 вересня у часописі «Стрілець» (друкований орган Галицької армії) з'явилася стаття 0. Назарука під заголовком «До булави треба голови». Вже сама ï назва була скерована проти Петлюри як Головного отамана. У статті зазначалося, що галицьке військо хоробро билось із ворогом і здобуло столицю; а уряд нічого не зробив, щоб дізнатися де саме знаходиться ворог, і не подбав про своєчасне зруйнування мостів через Дніпро [5, с. 265].

Сам Чикаленко, розповідаючи про ті події, відзначав, що він та київський міський голова Рябцев зустрілися з представником Добровольчої армії полковником Стеселем, але той відмовився вести переговори з військами Директорії, заявивши, що українці набагато гірше більшовиків, адже йдуть проти «єдиної та неподільної Росії». Денікінські офіцери, доволі брутально, зробили зауваження Чикаленку, щоб той припинив спілкуватися з ними українською мовою. Прикметно, що один солдат Добровольчої армії встиг сказати Чикаленку, що серед їхнього війська чимало полтавців $\mathrm{i}$ харків'ян, і воювати проти українців вони не будуть [2, с. 338]. Проте у вересні 1919 р. між військами Директорії та збройними силами А. Денікіна розпочалися бойові дії.

За рішенням українського Комітету громадських організацій, Л. Чикаленка відкомандировано до Кам'янця-Подільського, де перебував тоді уряд, щоб з'ясувати обставини які призвели до «несподіваної» втрати Києва. Там Л. Чикаленко зустрівся із очільником 30УНР Є. Петрушевичем. Останній зустрів Чикаленка дуже привітно, адже був знайомий 3 його батьком. Мемуарист запитав: чому ж відбулася «київська трагедія» і війська генерала Кравса залишили місто? Є. Петрушевич відповів, що Денікіна підтримуває могутня Антанта, і з нею на конфлікт «ми не підемо» [2, с. 350]. Аргумент Л. Чикаленка, про те, що навесні 1919 р. повстанські загони отамана Н. Григор'єва розгромили «непереможні» війська Антанти і оволоділи Одесою, на $Є$. Петрушевича ніяк не подіяв. Розсталися Чикаленко і «диктатор» 30УНР вже доволі прохолодно і офіційно.
У Кам'янці відбулась і зустріч Чикаленка з Петлюрою. Головний отаман попросив мемуариста нелегально відвідати Новочеркаськ та Катеринодар, і провести переговори 3 представниками донського та кубанського козацтва щодо можливого співробітництва, адже існуванню їх автономій теж загрожувала великодержавна політика адміністрації генерала А. Денікіна. Українсько-денікінський фронт Чикаленко перейшов у доволі оригінальний спосіб: натовп мішечників на станції Попельня пересаджувався на платформи з українського бронепотягу на денікінський, і опинявся по той бік фронту [1, с. 40-41]. Військові цивільних пасажирів не чіпали, і Чикаленко врешті-решт опинився в Києві.

Далі спогади надають інформацію про подорож мемуариста разом із громадським діячем О. Х. Саліковським у жовтні 1919 р. до Ростова та Новочеркаська. Тут відбулися переговори з представниками Донського кругу та Кубанської ради, делегати яких виказали невдоволення великодержавною політикою генерала А. Денікіна [1, с. 75-76]. Проте місія української делегації завершилася нічим, далі розмов справа не пішла. «Попали в такий час, коли вже людям було не до нас» [2, c. 374].

Спостережливий свідок, Чикаленко у спогадах відзначав, що серед українського селянства, саме за денікінського режиму, значно зросла національна свідомість. Повертаючись із Дону до Києва, мемуаристу довелося чимало спілкуватися з хліборобами. Так, на його думку, в 1917 р. за Центральної Ради селянство було переважно байдужим до національної ідеї. Відтепер селяни жалкували, що на початку року не підтримали своєї, «місцевої», української влади.

Коли Чикаленко повернувся до української столиці, там вже перебували радянські війська, тому автор спогадів відійшов на деякий час від активної політичної діяльності і занурився в наукову роботу в археологічній комісії Академії наук [2, с. 383-384]. На цьому завершуються мемуарні оповідання про події 1919 року. Далі була діяльність Л. Чикаленка в уряді В. Прокоповича, подорож із Румунії пароплавом до Криму для переговорів з генералом 
П. Врангелем. Останній заявив українській делегації, що пролита кров між петлюрівцями i денікінцями не повинна стати на заваді спільній меті - визволення батьківщини від більшовиків [2, с. 403-404]. Однак військовополітичні реалії восени 1920 р. були вже зовсім іншими ніж за рік перед цим. Аналіз мему- арних свідчень Л. Чикаленка про події 1920 року заслуговують на окрему публікацію.

Таким чином, мемуарні свідчення громадсько-політичного діяча Л. Чикаленка $\epsilon$ важливим джерелом 3 історії внутрішніх та зовнішніх чинників, що характеризують становище Директорії УНР у 1919 році.

\section{Список використаних джерел}

1. Чикаленко Л. Уривки зі спогадів з років 1919-1920. Нью-Йорк: Наша батьківщина, 1963. 167 с.

2. Чикаленко Л. Уривки зі спогадів з років 1919-1920. // У кн.: Чикаленко Є. Щоденник (1918-1919). Київ: Темпора, 2011. С. 335-414.

3. Винниченко В. Відродження нації: Історія української революції, марець 1917 р. - грудень 1919 р. Київ: Вид-во політичної літератури, 1990. Ч. 3. 542 с.

4. Омелянович-Павленко М. В. Спогади командарма (1917-1920). Київ: Темпора, 2007. 608 с.

5. Мазепа І. Україна в огні й бурі революції 1917-1921рр.: Спогади. Київ: Темпора, 2003. 609 с.

\section{References}

1. Chikalenko L. Urivki zi spogadiv z rokiv 1919-1920. Nyu-York: Nasha batkivschina, 1963. 167 s.

2. Chikalenko L. Urivki zi spogadiv z rokiv 1919-1920. // U kn.: Chikalenko E. Schodennik (1918-1919). Kyiv: Tempora, 2011. S. 335-414.

3. Vinnichenko V. Vidrodzhennya natsiyi: Istoriya ukrayinskoyi revolyutsiyi, marets 1917 r. - gruden 1919 r. Kyiv: Vid-vo politichnoyi literaturi, 1990. Ch. 3.542 s.

4. Omelyanovich-Pavlenko M. V. Spogadi komandarma (1917-1920). Kyiv: Tempora, 2007. 608 s.

5. $\quad$ Mazepa I. Ukrayina v ogni j buri revolyuciyi 1917-1921rr.: Spogadi. Kyiv: Tempora, 2003. 609 s.

\section{Пархоменко В. Историко-мемуарное наследие Л. Чикаленко про события 1919 г. в Украине \\ В статье на основании воспоминаний общественного деятеля Л. Чикаленко освещены события Украинской революции в 1919 году. Рассказывается о потери войсками Директории Киева, встре- чах мемуариста с Е. Петрушевичем и С. Петлюрой, переговоры с представителями Дона и Кубани. \\ Ключевые слова: Чикаленко, мемуари, Директория, Украинская революция.}

Parkhomenko V. Historical and memoir heritage of L. Chikalenko about events 1919 in Ukraine

In the article on the basis of remembrances of publicman L. Chikalenko is light up the events of Ukrainian revolution in 1919. Told about a loss by the troops of Directory of Kyiv, meeting of memorialist with Y. Petrushevich and S. Petlyura, negotiations with the representatives of Don and Kuban.

It is marked that opposition over between the leaders of UPR and WUPR was brought to the further dissidence among the political elite of Ukraine, and defeat of liberation fight.

Attention is drawn to the personal context of the formation of the complex of the patriotic memoirs about the events of the Ukrainian revolution, personal motivation to write memoirs.

Analyzing of memoirs heritage turns its degree of objectivity, the importance of admitting an actual material, the value of this information of scientifically balanced picture of the processes of formation of statehood, the international situation and the foreign policy of Ukraine, the reasons of the defeat of the national liberation struggle in 1919.

It is noted that the active involvement of the memoir heritage will contribute to a maximum of an objective picture of historical events, to intensify the study of processes in early XX century by representatives of academic historical scholarship.

Keywords: Chikalenko, memoirs, Directory, Ukrainian revolution. 


\title{
Розділ 4 \\ ІСТОРИЧНЕ КРАЄЗНАВСТВО
}

DOI: 10.33310/2519-2809-2019-47-1-98-103

УдК 94(477.73)

\author{
ВІТАЛІЙ КУЧЕР \\ аспірант кафедри історії та археології \\ Миколаївського національного університету імені В. О. Сухомлинського \\ e-mail: sventoslav@gmail.com

\section{РОЗВИТОК СІЛЬСЬКОГО ГОСПОДАРСТВА МИКОЛАЇВСЬКОЇ ОБЛАСТІ НАПРИКІНЦІ ХХ - НА ПОЧАТКУ ХХІ ст.}

\begin{abstract}
У статті проаналізовано розвиток сільського господарства Миколаївської області наприкінці XX - на початку XXI ст. Обгрунтовано важливу роль цієї галузі економіки для Миколаївщини. Визначено фактори, які сприяють та гальмують розвиток села. На основі досліджених матеріалів виділено етапи розвитку сільського господарства краю. Досліджено кризу цієї галузі економіки наприкінці ХХ ст. Проаналізовано ї̈ причини. Роз'яснено методи та процеси виходу сіл регіону із кризового стану. Досліджено помилки, що допущено у реалізації антикризових заходів.

Ключові слова: Миколаївщина, сільське господарство, врожай, криза, фермерство, аграрні перетворення, зрошувальні землі.
\end{abstract}

На сучасному етапі розвитку аграрного сектору України одним з найважливіших економічних регіонів залишається Миколаївська область. Варто наголосити на значенні сільського господарства Миколаївщини станом на кінець 2016 р., адже за рівнем розвитку ця галузь економіки посідала друге місце за обсягами та перше із зайнятості трудових ресурсів матеріального виробництва області. Природно-ресурсний потенціал склав 2 млн. га сільськогосподарських угідь, з яких 1,7 млн га ріллі, що склало 5\% орної землі України. Нараховувалось 5,0 тис. га виноградників плодоносного віку, 3,5 тис. га плодово-ягідних насаджень. У господарствах області розташовано 200 тис. га зрошувальних земель, відповідно на одного мешканця припадало майже 1,4 га ріллі, або в 2 рази більше ніж в середньому по Україні. На одного працівника, зайнятого в сільському господарстві, приходилось понад 11 га орної землі, що є одним із найвищих показників в державі. Питома вага області в рес- публіканському виробництві сільськогосподарської продукції досягала 3\%. Виробнича структура сільського господарства $є$ рослинницько-тваринницькою. Питома вага продукції рослинництва в загальному обсязі сягала $60 \%$. Основними культурами рослинництва в області $\epsilon$ зернові (озима пшениця, ярий ячмінь, кукурудза), якими зайнято більш ніж $40 \%$ посівних площ, технічні культури (соняшник та цукрові буряки), овочевобаштанні культури. Розвинуте садівництво та виноградарство. У середньому за рік область виробляє до 2 млн. тонн зерна, більш як 230 тис. тонн соняшника, до 200 тис. тонн цукрових буряків, понад 200 тис. тонн овочів тощо. Миколаївщина виробляє $5,7 \%$ українського зерна. Також важливим фактором $є$ те, що Миколаївська область може забезпечити власні потреби у виробництві сільськогосподарської продукції. Проте, м'яса виробляється лише 50\% від необхідної норми споживання населенням області [16]. 
Отже, наведений статистичний матеріал доводить, що визначення потенційних можливостей розвитку сільського господарства Миколаївщини на сучасному етапі можливе тільки на підставі з'ясування причин кризових явищ наприкінці XX ст. та шляхів їх подолання. Задля збереження економічного потенціалу Миколаївської області та подальшого його розвитку необхідно провести комплексний об'єктивний аналіз стану сільськогосподарської галузі у складний період становлення та розвитку незалежної Української держави.

Дослідженню розвитку сільського господарства Миколаївщини присвячено наукові розвідки багатьох учених. Зокрема, у роботі Соболя П. І. «Нариси історії Миколаївщини XX ст.» (2005 р.) [14] визначено стан соціально-економічного розвитку області. Науковці Шкварець В. П., Горбуров Є. Г. та Горбуров К. Є. у книзі «Повоєнна та сучасна Миколаївщина» (2008р.) [18] розкрили напрямки i пріоритети економічного розвитку Миколаївської області у кінці XX - початку XXI ст. У монографії Малюка С. О. «Ресурси аграрного сектору економіки та їх використання на підприємствах сільських територій» (2015р.) висвітлено фактори, що сприяють та гальмують його розвиток [13]. У 2016 р. під керівництвом Шитюка М. М. публікується дослідження «Історія рідного краю: Миколаївщина» [17], у якому подано стан сільського господарства регіону на початку незалежності України. Проте названі вище дослідження не дозволяють визначити всі напрями стану та розвитку сільського господарства, а наявні певні данні потребують подальшої деталізації та уточнення на підставі узагальнення архівних джерел.

Наприкінці XX - на початку XXI ст. процес розвитку сільського господарства Миколаївської області на території України поділяється на три етапи:

Перший - від проголошення незалежності України до 1994 р. Цей етап характеризувався падінням обсягу сільськогосподарського виробництва, погіршенням матеріальнотехнічної бази та фінансового стану села. Основною метою став порятунок сільського господарства від повної загибелі [18, 103 с.].
Другий етап розпочався із прийняття президентського указу «Про невідкладні заходи щодо прискорення земельної реформи у сфері сільськогосподарського виробництва» від 10 листопада 1994 р. Завдяки цьому указу було проведено роздержавлення землі та передачу їі у власність колективним господарствам. Проте, відсутність змін в організаційноправових формах господарювання та не налагоджені ринкові механізми призвели до найнижчого рівня використання земельних ресурсів в країні, повної відсутності фінансування аграрного сектору, заміни грошових відносин бартерними [18, 103 с.].

Початком третього етапу аграрного розвитку, який триває і до нашого часу, став указ Президента України Л. Д. Кучми «Про невідкладні заходи щодо прискорення реформування аграрного сектора економіки» від 03.12.1999 р. Відповідно до якого набули розвитку майнові відносини, сформовано сектор фермерських господарств, розширено землекористування особистих господарств населення, закладено основи приватної ініціативи та конкуренції [18, 104 с.].

Характеризуючи розвиток сільського господарства Миколаївської області у 19911994 рр., варто звернути увагу на доповідну записку голові Миколаївського облвиконкому Грицаю I. Т. від його першого заступника Башкірова М. В. У документі наголошувалось, що у зв'язку із зниженням обсягів виробництва сільськогосподарської продукції у регіоні зменшуються обсяги виготовлення продовольчих товарів харчової та переробної галузей промисловості. У недостатньому забезпеченні населення області продуктами харчування Башкіров звинувачує бездіяльність Кабінету Міністрів України та республіканські відомства. Фонди харчової та переробної промисловості не оновлювались з 1985 р. Що стосується обладнання підприємств, то вони не були модернізовані з другої половини 1960-х - початку 1970-х рр. Окрім дефіциту обладнання, спостерігався дефіцит імпортної сировини для виготовлення харчової продукції [5, 39 с.].

Облвиконком вже не мав належних повноважень, щоб впливати на роботу підприємств, які мали господарську самостійність [5, 40 c.] 
Башкіров наголошував на необхідності іноземних інвестицій шляхом створення сумісних підприємств, закупівлі технічного обладнання та сировини за кордоном. Вже десятки сумісних підприємств майже не працювали, лише укладали разові комерційні угоди, які не вирішували питання нарощування об'єму, асортименту та якості продукції. [5, 40 с.] Заслуговує уваги той факт, що засоби масової інформації формували негативний образ зовнішньоекономічної співпраці регіональних підприємств [5, 41 с.].

Зауважимо, що звіт Миколаївського виробничого об'єднання елеваторної та зернопереробної промисловості за жовтень 1991 р. демонструє халатне ставлення місцевих завгоспів до зберігання врожаю. Зокрема, під час перевірки інспекторами та спеціалістами виявлено, що зерно, соняшник та інші продукти зберігались раніше та надалі продовжують зберігатись у стані зараження шкідниками хлібних запасів. Деякі підприємства не тільки не знизили рівень зараженості, але й допустили зараженість нових партій продукції [3, 47 с.].

Варто наголосити, що у жовтні 1992 p. спостерігалась аналогічна ситуація із неналежним зберіганням сільськогосподарської продукції, попри вжиті заходи контролю [4, с. 63.]. У тому ж році об'єднання елеваторної та зернопереробної промисловості звітувало, що план із заготівель гібридного насіння кукурудзи у 1991 р. не виконав жоден завод через неналежну увагу їх директорів до цього продукту. Також спостерігалось недостатнє комплектування обладнанням та проведення реконструкції кукурудзяно-калібровочного цеху Камено-Мостового хлібного підприємства. Здійснювалась затримка осушення та обмолу насіння кукурудзи [4, с. 41].

Обласне управління земельних ресурсів у березі 1994 р. звітувало, що у багатьох районах області спеціальні комісії та прокуратура перевіряла виконання закону України «Про селянське/фермерське господарство в межах району». Перевірки встановили, що в області спостерігались численні порушення порядку приймання та розгляду заяв громадян про надання земель для ведення селянських/ фермерських господарств. Спостерігалось не тільки незадовільне ведення документації 3 реєстрації заяв громадян на одержання земельних ділянок різного цільового призначення, а й відсутність господарських книг для запису даних про фермерські господарства, журналів реєстрації державних актів на землю, договорів оренди земельних ділянок. Обласне управління земельних ресурсів причиною таких порушень вважало відсутність контролю 3 боку районних представництв управління та халатне ставленням до своїх службових обов'язків спеціалістів землевпорядної служби [2, с. 5].

Треба зауважити, що занепад та криза сільського господарства України стали наслідком багаторічного існування колгоспної системи. Попри всі позитивні якості, які їй приписували за радянських часів, сучасні історики довели, що вона призвела до зниження зацікавленості селян у результатах своєї праці та економічної відповідальності суб'єктів господарювання [18, с. 64-65].

На початку XXI ст. відбулось покращення економічної ситуації в селах України. Статистичні данні $є$ яскравим тому підтвердженням. Так, виробництво валової продукції сільського господарства у 2001 р. збільшилось у 1,5 рази у порівнянні з минулим роком. А кількість збиткових підприємств навпаки скоротилась на $44 \%$ [18, с. 105$]$.

Варто зауважити, що указ президента «Про невідкладні заходи щодо прискорення реформування аграрного сектору економіки» допоміг Миколаївщині стабілізувати рівень виробництва сільськогосподарської продукції. Так, станом на 2001 р. її виробництво збільшилось на 45,4\% і наступні два роки становило понад 2 млрд грн проти 1,5 млрд грн у 2000 р. Таким позитивним результатам сприяло збільшення виробництва зернових культур до 5,2 млн тонн протягом 20012002 pр. У той же час ліквідовано борги із заробітної плати на суму 80 млн грн, проведено розрахунки за оренду земельних та майнових паїв, комерційним банкам своєчасно повернули кредити [9, с. 17].

За 2000-2003 рр. посівні площі зернових культур та цукрового буряку зросли у 1,4 рази, а соняшника у 1,5 разів. За 2001-2003 pp. врожайність зернових зросла на 75,5\%, соняшнику на 15,9\%, цукрових буряків на 
68,5\% [8, с. 24]. Варто наголосити, що завдяки аграрній реформі селяни отримали нове джерело доходу у вигляді орендної плати за використання сільгосппідприємствами їх землі та майна. Протягом 1999-2003 рр. в рахунок орендної плати видано сільгосппродукції, надано послуг та виплачено грошовими коштами 506,8 млн грн, при цьому рівень розрахунків в середньому за звітний період становив $96 \%$ [9, с. 50].

Одним із факторів розвитку агропромислового комплексу Миколаївщини стала його взаємодія з банківськими установами області. Факторами розвитку сільського господарства та активізації кредитування стали сприятливі природні і кліматичні умови. Не менш важливим $\epsilon$ економічне значення аграрного сектору, який, як вже зазначалось, посідає друге за обсягами та перше із зайнятості трудових ресурсів області [17, с. 154].

Варто звернути увагу на чинники, які гальмують активізацію кредитування. Це не тільки сезонність виробництва з його залежністю від погоди, а й несприятлива кон'юктура на ринку продукції і попиту зерна. Не менш важливою перепоною стала відсутність ліквідної застави, нерозвинута система страхового захисту фінансових операцій. Проблемні питання кредитної політики аграрного сектору не можуть бути вирішені без визначень концептуальних підходів та без формування чіткої стратегії ії розвитку. Дуже важливим $\epsilon$ розробка та вдосконалення законодавчої бази, створення належного правового підгрунтя, що допоможе виробити більш ефективні механізми фінансування сільськогосподарського сектору [17, с. 157].

Не зважаючи на негативні фактори, початок XXI ст. характеризувався суттєвим зростанням обсягу кредитної допомоги. Вона збільшилась у 1,83 рази. Пік активності припадає на 2005 р. Саме цього року стали більш доступними кредити для малих та фермерських господарств. Порівняно з 2004 р. кількість кредитів для фермерських господарств зросла у 1,93 рази, а їх частка в загальному кредитному портфелі збільшилась 324 до $29 \%[17$, с. 154$]$.

Найвищого піку розвитку, у порівнянні $з$ 1991 р., сільське господарство досягло у тому ж 2005 р. Обсяги виробництва збільшились на 53,7\%. Цьому сприяла активна кредитна допомога. Існувала можливість ще більш суттєвого зростання рівня виробництва продукції, але цьому завадило зменшення виробництва зернової продукції $[10$, с. 17]. Також варто зауважити, що для повноцінного розвитку сільського господарства Миколаївської області бракує відповідних заходів, а саме: технічне переоснащення, ефективне використання зрошуваних земель, збереження наявного поголів'я худоби та птиці [9, с. 50].

Несприятливим фактором була й нездатність української влади вчасно реагувати на аграрні проблеми регіону. Так, восени 2006 р. навесні 2007 pp. несприятливі погоднокліматичні умови супроводжувались пошкодженням пиловою бурею 646,8 тис. гектарів 3 858 тис. наявних у області. У травні 2007 р. грунтова та повітряна посуха охопила всі врожайні землі Миколаївщини. 500 тис. гектарів ранніх зернових культур не змогли дати врожай. 55 тис. списано. Площі загибелі посівів щорічно збільшувались. Збитки сягали близько 1 млрд гривень [6, с. 109].

Спостерігалось стримування проведення страхування посівів сільськогосподарських культур внаслідок несвоєчасного здешевлення вартості фактично сплачених страхових премій через відсутність коштів, які, згідно до постанови Кабінету Міністрів України від 21.02.2007 p. № 261, пропорційно розподіляються серед областей держави. Виділено 3,3 млн гривень 3 помісячним розподілом, основна сума виділена на вересень-грудень 2007 р. У травні область отримала лише 120 тис. гривень. Водночас лише одна галузь господарства потребувала компенсації від 50 до 300 тис. грн [6, с. 109].

3 метою підтримки комплексного розвитку фермерських та селянських господарств, а також захисту їх прав 23.07.2008 р. створено Миколаївську обласну асоціацію фермерів та приватних землевласників «Відродження». Протягом 2008-2010 рр. збільшувалась кількість фермерських господарств з 4445 до 4638. Проте, як свідчить проаналізований нами матеріал, заходи підтримки села не набули системного характеру. У 2011 р. починається зменшення фермерських господарств 
до 4574, що пов'язано 3 недостатньою підтримкою розвитку фермерства. У той же час, станом на 2012 р. площа сільськогосподарських угідь зросла до 347,6 порівняно з 273,8 га у 2008 р. [13, с. 50]. За цей період також спостерігалось зростання обсягу валової продукції сільського господарства на 36,93\% по області. Проте, не у всіх районах спостерігались позитивні зрушення. Так у Новобузькому районі відбулось скорочення виробництва на $14,26 \%[13$, c. 51$]$.

Варто зауважити, що попри позитивні наслідки, спостерігались негативні тенденції. 91 підприємство області $(19,6 \%)$ виявились збитковими $[13$, с. 57$]$, що пояснюється, як вже зазначалось вище, недостатнім технічним забезпеченням, так й застарілою сільськогосподарською технікою та її скороченням.

В Україні у 2013 р. питома вага Миколаївщини у виробництві продукції сільського господарства становила 3,7\% (у 2012 р. - 3,1\%). Обсяг валової продукції сільського господарства (у постійних цінах 2010 р.) за той самий рік становив 9394,1 млн грн, на 35,4\% більше від рівня 2012 р. За цим показником область посіла 15 місце в Україні [15, с. 14-15].

Після російської окупації Криму Миколаївська та Херсонська області стали лідерами за рівнем розвитку фермерства в Україні, зосередивши абсолютну більшість зрошувальних земель держави. У журналі «Український тиждень» № 5 від 11.02.2016 р. наголошувалось на тому, що ці дві області мають великий нереалізований потенціал сільськогосподарського розвитку, який при належному управлінні можна збільшити вдвічі [12, с. 17].

Отже, на основі дослідженого матеріалу можна зробити висновок, що сільське господарство Миколаївської області зіштовхнулось 3 негативними тенденціями ще за часів горбачовської «перебудови». На початку утворення незалежної України зміна підходів, ліквідація совхозно-колгоспної системи супроводжувалось падінням інтенсивності виробництва галузі. Проте, нова українська влада вжила недостатньо заходів для належного реформування та подальшого стабільного розвитку сільського господарства.

\section{Список використаних джерел}

1. Державний архів Миколаївської області (Далі - ДАМО): Информационные сведения направленные в государственный комитет Украины по хлебопродуктам о результатах контроля за работой хлебоприемных предприятий области 2 февраля 1993 - 10 января 1994. Ф.: Р-2906, оп. 2, спр. 371.43 с.

2. ДАМО: Миколаївське обласне управління земельних ресурсів Накази начальника управління з основної діяльності 5 січня - 28 грудня 1994 р.Ф.: Р-6084, оп. 1, спр. 6. 36 с.

3. ДАМО: Приказы с № 1 по № 38 начальника госхлеб-инспекции по основной деятельности 2 января - 27 декабря 1991. Ф.: Р-2906, оп. 2, спр. 355.47 с.

4. ДАМО: Приказы с № 1 по № 52 начальника госхлеб-инспекции по основной деятельности 2 января 30 декабря 1992. Ф.: Р-2906, оп. 2, спр. 363.63 с.

5. ДАМО: Протокол № 4 заседания исполнительного комитета областного Совета народных депутатов от 18 февраля 1992 года. Ф.: Р-992, оп. 12, спр. 4952.79 с.

6. ДАМО: Протоколи № 10 по № 15 засідань постійної комісії обласної ради з питань аграрної політики, земельних відносин, сільського будівництва та соціального розвитку села 23 січня - 30 травня 2007. Ф.: 6121, оп. 1, спр. 643. $125 \mathrm{c}$.

7. ДАМО: Рішення восьмої сесії Миколаївської обласної ради четвертого скликання від 25 квітня 2003 року. Рішення 3 № 1 по № 11. Ф.: 6121, оп. 1, спр. 398. 203 с.

8. ДАМО: Рішення тринадцятої сесії Миколаївської обласної ради четвертого скликання від 17 грудня 2003 року. Рішення з № 1 по № 3. Ф.: 6121, оп. 1, спр. 416. 209 с.

9. ДАМО: Рішення двадцять першої позачергової сесії Миколаївської обласної ради четвертого скликання від 30 грудня 2004 року. Рішення з № 1 по № 10. Ф.: 6121, оп. 1, спр. 464. 186 с.

10. ДАМО: Рішення тридцятої сесії Миколаївської обласної ради четвертого скликання від 12 січня 2006 року. Рішення 3 № 1 по № 12. Ф.: 6121, оп. 1, спр. 539. 201 с.

11. Історія рідного краю. Миколаївщина. Навчальний посібник / М.Шитюк, О.Баковецька, Н.Буглай та інші. Миколаїв: Іліон, 2016. 628 с.

12. Крамар О. І. Причорномор'я: Складна реальність, великі перспективи. Украӥнський тиждень. 2016. № 5. С. 16-19.

13. Стратегія розвитку Миколаївської області на період до 2020 року [Електронний ресурс] - Режим доступу: http:// www.mk.gov.ua/ua/economy/strateg.

14. Малюк С. О. Ресурси аграрного сектору економіки та їх використання на підприємствах сільських територій: монографія. Миколаїв: Іліон, 2015. 210 с.

15. Соболь П. І. Нарис історії Миколаївщини. XX століття: Навчальний посі-бник. Миколаїв: Вид-во МдгУ ім. Петра Могили, 2005. $173 \mathrm{c}$.

16. Україна сьогодні. Каталог провідних підприємств України [Електронний ресурс] - Режим доступу: http:// www.rada.com.ua/ukr/RegionsPotential/Mykolaiv. 
17. Шитюк М. М. Аналіз взаємодії аграрного сектору АПК з банківськими установами Миколаївщини. Історія. Етнографія. Культура. Нові дослідження: VI Миколаївська обласна краєзнавча конференція. Миколаїв: Можливості Кіммерії, 2006. С. 154-157.

18. Шкварець В. П., Горбуров Є. Г., Горбуров К. Є. Повоєнна та сучасна Миколаївщина. Монографічне історико-краєзнавче дослідження. Миколаїв: Видавництво «Шамрай», 2008. 300 с.

\section{References}

1. Istoriya ridnoho krayu. Mykolayivshchyna. Navchal'nyy posibnyk/M.Shytyuk, O.Bakovets'ka, N.Buhlay. Mykolayiv: Ilion, 2016. $628 \mathrm{~s}$.

2. Kramar 0. I. Prychornomor'ya: Skladna real'nist', velyki perspektyvy. Ukrayins'kyy tyzhden' № 5. 2016. s. 16-19.

3. Stratehiya rozvytku Mykolayivs'koyi oblasti na period do 2020 roku [Elektronnyy resurs] - Rezhym dostupu: http:// www.mk.gov.ua/ua/economy/strateg.

4. S. O. Malyuk. Resursy ahrarnoho sektoru ekonomiky ta yikh vykorystannya na pidpryyemstvakh sil's'kykh terytoriy: monohrafiya. Mykolayiv : Ilion, 2015. 210 s.

5. Sobol' P.I. Narys istoriyi Mykolayivshchyny. KHKH stolittya: Navchal'nyy posi-bnyk. Mykolayiv: Vyd-vo MDHU im. Petra Mohyly, 2005. $173 \mathrm{~s}$.

6. Ukrayina s'ohodni. Kataloh providnykh pidpryyemstv Ukrayiny [Elektronnyy resurs] - Rezhym dostupu: http:// www.rada.com.ua/ukr/RegionsPotential/Mykolaiv.

7. Shytyuk O.M. Analiz vzayemodiyi ahrarnoho sektoru APK z bankivs'kymy ustanovamy Mykolayivshchyny. Istoriya. Etnohrafiya. Kul'tura. Novi doslidzhennya: VI Mykolayivs'ka oblasna krayeznavcha konferentsiya. Mykolayiv : Mozhlyvosti Kimmeriyi, 2006. s. 154-157

8. Shkvarets' V.P., Horburov YE.H., Horburov K.YE. Povoyenna ta suchasna Mykolayivshchyna. Monohrafichne istorykokrayeznavche doslidzhennya. Mykolayiv: Vydavnytstvo «Shamray», 2008. 300 s.

Кучер В. Развитие сельского хозяйства николаевской области в конце XX - начале XXI в.

В статье проанализировано развитие сельского хозяйства Николаевской области в конце XX начале XXI в. Обоснованно важную роль этой отрасли экономики для Николаевщины. Определены факторы, способствующие и тормозят развитие села. На основе исследованных материалов выделены этапы развития сельского хозяйства края. Исследована кризис этой отрасли и проанализированы их причины. Разъяснены методы и процессы выхода региона из кризисного состояния. Исследованны ошибки, которые были допущены при реализации антикризисных мер.

Ключевые слова: Николаевская область, сельское хозяйство, урожай, кризис, фермерство, аграрные преобразования, орошаемые земли.

\section{Kucher V. Development of agriculture of Mykolaiv region at the end of the XX - beginning of the XXI century}

The article analyzes the development of agriculture in the Mykolaiv region at the end of the XX - beginning of the XXI century. The historiography is given, in which attention is paid to the investigated problem. The main types of agriculture, which are inherent in Mykolayiv region, are described. The important role of this branch of economy for the Mykolaiv region is substantiated. The factors that promote and hinder the development of the village are identified. The influence of the Soviet past on the current socio-economic situation of agricultural production has been analyzed. On the basis of the investigated materials, the stages of agricultural development in the region are highlighted: the first - from the proclamation of Ukraine's independence until 1994; the second - from 1994 to 1999, the third - from the end of 1999 and continues until our time. The historical development of agriculture of certain periods is analyzed in detail, based on archival sources, statistical material and scientific works of historians. The crisis of this branch of economy at the end of the twentieth century was investigated. Its causes are analyzed. The cases of arbitrariness and negligence during the preservation of the crop have been demonstrated. The methods and processes of the exit of the villages of the region from the crisis state are explained. An assessment was made of measures taken by the Ukrainian authorities aimed at implementing agrarian reforms in the areas of Mykolayiv region. The important role of credit aid to the agriculture of the region is substantiated. Considerable attention is paid to the development of farming in the territory of the Mykolaiv region. The factors that hampered the spread of the farm were identified. The errors that were admitted in the implementation of anti-crisis measures were investigated. The promising opportunities for the development of agriculture in the region of Mykolaiv region after the Russian annexation of Crimea have been demonstrated. The unrealized measures that contributed to an increase in agricultural production volumes in the Mykolaiv region were determined. land.

Key words: Mykolayiv oblast, agriculture, harvest, crisis, farming, agrarian transformation, irrigated 
DOI: 10.33310/2519-2809-2019-47-1-104-107

УДК 94(477.87)«1950/1953»:008:070

\author{
GВА КІШ \\ доктор історичних наук, професор, \\ завідувач кафедри історії Угорщини та європейської інтеграції, \\ Українсько-угорський навчально-науковий інститут, \\ Ужгородський національний університет, м. Ужгород \\ член зовнішньої колегії Академії Наук Угорщини \\ e-mail: kish.eva15@gmail.com

\begin{abstract}
КАМІЛЛА МАРОШАН
Магістр історії кафедри історії Угорщини та європейської інтеграції,

Українсько-угорський навчально-науковий інститут,

Ужгородський національний університет, м. Ужгород

e-mail: mkamilla996@ gmail.com
\end{abstract}

\section{ОСОБЛИВОСТІ ФУНКЦІОНУВАННЯ КУЛЬТУРНИХ ЗАКЛАДІВ ЗАКАРПАТТЯ ЗА ПЕРІОД 1950-1953 РОКІВ НА ОСНОВІ МАТЕРІАЛІВ ПРЕСИ}

\begin{abstract}
Стаття присвячена питанням функціонування закарпатських культурних закладів у радянський період між 1950 і 1953 роками. Дана характеристика діяльності бібліотек того часу, досліджено твори із найпопулярніших тем, у тому числі презентовано газети, кіно і музеї. Досліджено процеси реформування освіти. На Закарпатті радянська влада довго не могла нічого зробити з вихованням неслов'янських народів. Для неслов'янських громад, як свідчать джерела, було важко адаптуватися до нової політичної системи і нової як для Закарпаття комуністичної ідеології.

Ключові слова: Закарпаття, культура, преса, освіта, ідеологія.
\end{abstract}

Протягом 1950-1953 повоєнних років культурне життя Радянського Союзу відновилося, в тому числі і на Закарпатті. Музеї, театри, галереї та бібліотеки відкривалися поспіль. У більшості сільських клубів відкрито бібліотеки, де крім російськомовних книг, було також багато книг угорською мовою. Наприклад, лише Закарпатська територіальна бібліотека (ЗТБ) у 1952 році збільшилася на 20 тисяч книг. За період 1946-1952 років кількість книг, доступних у ЗТБ, збільшилася в 17 разів. У майже кожному селі була власна бібліотека, в цей період на Закарпатті було 500 сільських бібліотек, які у кількісному підсумку мали мільйон томів. Переважна більшість 3 них це російськомовна література. Таким чином, громадськість Закарпаття мала можливість ознайомитися з великою кількістю класичної літератури та творами видатних авторів та поетів. Бібліотеки Закарпаття часто поповнювалися новими серіями книг. Звичайно, слід зазначити, що багато книг на угорській мові були знищені, саме ті, які не відповідали очікуванням комуністичної ідеології.

Актуальність теми дослідження визначається важливістю аналізу культурного життя краю саме у повоєнний період. Важливими $€$ також дослідження реформи освіти. Метою даної публікації $є$ аналіз специфіки функціонування закарпатських культурних закладів у радянський період між 1950 і 1953 роками. Публікацій, де започатковано вивчення даної тематики майже немає. Це дослідження ми здійснили на основі першоджерел - преси Закарпаття повоєнного періоду.

У 1950 році видано на Закарпатті наступні книги угорською мовою: «Й. В. Сталін: Коротка біографія»; В. Нєкрасов «У траншеях Сталінграда»; Аркадій Гайдар «Тимур і його 
команда»; 0. Гончар «Прапороносці»; Лев Кассіль «Дорогі мої подруги»; Іван Франко «Розповіді», Л. М. Коралл «Вчимося українською: практична мовна книга». Ціна книг становила від 3 до 9 рублів [19].

У 1950 році шкільні районні бібліотеки міста Мукачево також розширили палітру нових книг із літературних і політичних сюжетів. В області налічувалось 93 шкільних бібліотеки з десятками тисяч книг. Серед нещодавно придбаних книг - твори Леніна i Сталіна, Л. Толстого, О. Пушкіна, Т. Шевченко, праця лауреата Сталінської премії - Акаєва В. «Біла береза» і багато інших [23].

У 1951 році твір Сталіна «Марксизм і мовознавство» видано українською мовою в 50000 примірників [17]. Теоріі К. Маркса і Ф. Енгельса пропагували історичний матеріалізм, основні принципи якого були розроблені ще у XIX столітті [6].

Протягом 1952 року у селах та у робочих клубах Закарпаття відкрито 140 нових бібліотек. У квітні дитячі бібліотеки були відкриті в Береговому, Виноградові і Рахові. Бібліотекам призначені відповідні приміщення і виділені фонди на купівлю книг. За даними газети «Карпати Ігаз Co» (Kárpáti Igaz Szó, переклад з угорської мови: «Закарпатське правдиве слово») у 1952 році було три з половиною мільйона книг [20].

Студенти Ужгородського державного університету опублікували п'ять номерів «Наукових записок», насамперед, це праці 3 біологічних, медичних, історико-лінгвістичних питань. «Студентка п'ятого року навчання біологічного факультету, Куц О. В. підняла актуальні питання: ремонт комбікормової бази худоби Карпатських гір. За темою «Грибкові захворювання фруктових дерев i шкідників яблуні в Тячівській області» була написана стаття Бубр'яком та Ліковичом студентами університету. «Випускники з історії та філології також писали наукові роботи на цікаві теми. 3 біології та медицині написали 15 наукових робіт, шість 3 історії та філології» [7].

У ці роки почали з'являтися за підпискою журнали та газети: «Закарпатська правда», «Радянське Закарпаття», «Молодь Закарпаття», «Кишеньковий довідник агітатора» - їх підписка коштувала від 1 до 5 рублів на місяць [13]. Але не всі були задоволені книжковим сервісом тих років: «Я коваль, - пише М. Павлюк, але я не можу знайти книгу в бібліотеці, яка б інформувала нас про технічні досягнення нашої країни. Загалом, бібліотека $\epsilon$ бідною і технічних виданнях не має». У бібліотеці Великих Бичків було 4,500 книг в 1952 році, а у 1953 році отримали ще 418 книг. Тому база досить велика, як для села, але вона не може задовільнити потреби читачів [4].

Протягом 1950-1953 років в регіоні були організовані численні курси для вчителів. Для відпочинку дітей створено піонерські табори, проте їх недоліки рідко обговорюються на сторінках газет. У 1951 році профспілками організовано 72 піонерських табори. Піонерські табори були відкриті в перші дні червня, але обласна рада профспілок не завершили розміщення дітей в таборах, школах і дитячих курортах до 14 липня, що було зазначено у пресі [2; 3].

У 1951 році в регіоні організована навчальна поїздка для 75 вчителів, ї̈ учасники відвідали Київ, Харків та інші міста республіки. Вони ознайомились 3 великими промисловими підприємствами, театрами, музеями і галереями, а також відвідали багато провідних дитячих установ, зустрілися з вчителями та письменниками. У Києві вони відвідали центральну станцію Агробіології, в Харкові педагогічний інститут: «Більшістьучасників це були молоді викладачі з сіл Карпатських гір. Серед них: Мельничук К. викладач початкової школи в Рагові, Філіпко М. із середньої школи Сваляви» [10]. У 1951 році п'ять студентських колективів з викладачами Ужгородського державного університету разом з колегами, здійснили поїздки в Москву, Ленінград, Київ та інші великі індустріальні міста країни. Студенти, які брали участь у екскурсії, також відвідали найбільші міста Закарпаття: Мукачево, Берегове, Солотвіно, Рагове, Ясиню. В Солотвині вони знайомляться з роботою деревообробних заводів в гірських районах області [1].

У травні 1952 р. студенти хімічного та біологічних факультетів Ужгородського державного університету здійснювали практику в найбільших ботанічних садах та музеях 
Радянського Союзу. У жовтні 1953 р. археологи зі Львова провели археологічні розкопки на Поділлі. Експедицію очолював кандидат історичних наук Й. Захарук. «На розкопках, проведених в Кошіловці в Тернопільському районі, збереглися залишки так званої Трипільської культури, що розташована на стародавніх землях. В одному з цих місць, знайшли спалений людський череп» [15].

У перші місяці 1953 року організовано театральні вистави і концерти. Так, 8 лютого, наприклад, в Ужгороді піаністкою Дежо Задор із Музичної школи виконано сонату Ференца Ліста і твори Чайковського, 23 лютого проведено черговий концерт в філармонії Ужгорода [22].

Волонтерські працівники села Вільгівці працювали $з$ метою розвитку своїх культурних інституцій, покращували умови шкіл, бібліотек, клубів: «Вайнахій Івана, Іван Бажа, Мартін Андрій колгоспники, перевозять 300 кубічних метрів деревини для школи. Нехай наші діти почуваються краще, і вчитися будуть краще» [12].

Протягом 1950-х років розширюється мережа галерей на Закарпатті. Мета їх створення - знайомство дітей і дорослих з роботами радянських митців [10]. Так, у жовтні 1953 р., після реконструкції, було відновлено Закарпатську обласну галерею із творами мистецтв із Росії, України та Західної Європи. Як вказувала тодішня преса, радянське відділення галереї значно зросло: по-перше, це мармурова скульптура «Ленін у віці гімназиста», робота молодого художника Галкіна Г. «Ленін В. І. та Крупська Н. К. у Горках», та картина Паргевського В. «Захисники Сталінграда», яка буде служити «невичерпною темою для радянських художників у всі часи. Картина $\epsilon$ найбільш вражаючим зображенням одного із славного міста-героя» [11].

У 1950-х роках кіностудії активно виготовляли фільми, які були спрямовані на виховання суспільства в радянському дусі. В Закарпатті створено мережу кінотеатрів. Преса у відповідному ракурсі «оспівувала» здобутки кінематографу: «Радянське кіно виробляло гарні фільми про героїчну історію Угорщини, революційну боротьбу радянського пролетаріату і незаможного селянства, про повалення експлуататорів, про нових людей країни Рад... Такі фільми, як «Секретна місія», «Звільнений Китай», «Вони боронили Батьківщину» отримали спеціальні премії» [21].

Важливу роль посідало спортивне життя краю. Наприклад, у липні 1951 р. у Харкові місцева команда «Локомотив» та Ужгородський «Спартак» провели Національний чемпіонат класу «Б» $з$ футболу. Закарпатці одержали перемогу і зайняли дев'яте місце в турнірній таблиці [8; 5].

Підсумовуючи, зазначимо, що саме протягом 1950-1953 років на Закарпатті, відбувся значний «культурний бум». Масово відкривались бібліотеки як в містах, так і у селах. Були відкрито клуби, більшість з яких були добре обладнані. Звичайно, були поселення, де населення не було задоволено культурними умовами відпочинку. Театральні виступи і радянські фільми, мали за мету розважати населення у рамках комуністичної ідеології. Проте у новосторених галереях, була можливість презентувати населенню картини і скульптури відомих художників, а також були організовані виставки саме угорських митців, наприклад, Ференца Редо і Шандора Міклоша.

\section{Список використаних джерел}

1. A diákok turistakirándulása. // Kárpáti Igaz Szó 32. évfolyam, 163. szám - 1951. július 13.

2. A gyerekek nyári üdültetése megszervezésének fogyatékosságairól. // Kárpáti Igaz Szó 32. évfolyam, 164. szám - 1951. július 14.

3. A gyerekek nyári üdültetése // Kárpáti Igaz Szó 32. évfolyam, 124. szám - 1951. május 29.

4. A könyvtárak helyreállításának fogyatékosságairól. // Kárpáti Igaz Szó 32. évfolyam, 209. szám - 1953. szeptember 4.

5. A sakkvilágbajnokságért // Kárpáti Igaz Szó 32. évfolyam, 85. szám - 1951. április 12.

6. A történelmi materializmus mint a társadalmi fejlődés törvényeiről szóló tudomány. // Kárpáti Igaz Szó 32 . évfolyam, 33. szám - 1953. február 7.

7. Az egyetemi hallgatók tudományos műveinek gyűjteménye. // Kárpáti Igaz Szó 32. évfolyam, 106. szám - 1952. május 6.

8. Az uzshorodi “SPARTAK" győzelme. // Kárpáti Igaz Szó 32. évfolyam, 173. Szám - 1951. július 25.

9. Baharjev B. Képtár az iskolában // Kárpáti Igaz Szó 32. évfolyam, 123. szám - 1952. május 25.

10. Baharjev B. Ukrajnai tanulmányút // Kárpáti Igaz Szó 32. évfolyam, 161. szám - 1951. július 11.

11. Csernega 0. A területi képtárban // Kárpáti Igaz Szó 34. évfolyam, 257. szám - 1953. október 30. 
12. Deljatyinszkij M. Atyai gondoskodás az iskolákról, a kulturfelvilágosító intézményekről. // Kárpáti Igaz Szó 32. évfolyam, 114. szám - 1951. május 16.

13. Folytatódik az előfizetés az 1953. évi második negyedére a következő területi lapokra // Kárpáti Igaz Szó 33. évfolyam , 64. szám - 1953. március 15.

14. Művészeti Múzeum Poltaván // Kárpáti Igaz Szó 32. évfolyam, 97. szám - 1951. április 25.

15. Ratau. A lvovi archeológusok értékes leletei. // Kárpáti Igaz Szó 34. évfolyam, 238. szám - 1953. október 8.

16. Ratau. A Sevcsenko G. T. Múzeumban // Kárpáti Igaz Szó 32. évfolyam, 109. szám - 1951. május 11.

17. Ratau. Sztálin J. V. a Marxizmus és a nyelvtudomány kérdései c. művének kiadása ukrán nyelven // Kárpáti Igaz Szó 32. évfolyam, 86. szám - 1951. április 12.

18. Redő Ferenc. Szovjet képzőművészek műtermeiben. // HISTÓRIA XI. évfolyam - 1989. 1-2 hó.

19. Új könyvek. // Kárpáti Igaz Szó 30. évfolyam, 70. szám - 1950. április 8.

20. Új könyvtárak. // Kárpáti Igaz Szó 32. évfolyam, 84. szám - 1952. április 8.

21. Vigyük közelebb a mozit a tömegekhez. // Kárpáti Igaz Szó 32. évfolyam, 83. szám - 1951. április 8.

22. Zádor D. J. zeneszerző szerzői hangversenye. // Kárpáti Igaz Szó 33. évfolyam, 47. szám - 1953. február 25.

23. Zsupanin I. Előadások kolhozisták részére. // Kárpáti Igaz Szó 30. évfolyam, 6. szám 1950. január 8.

Киш Е., Марошан К. особенности функционированния культурных учреждений Закарпатья за период 1950-1953 годов на основе материалов прессы

Статья посвящена вопросам функционированния культурных учреждений Закарпатья в советский период в 1950-1953 годах. Дана характеристика деятельности библиотек того времени, исследованы произведения на популярную тематику тех времен, в том числе представлены газеты, кино, музеи. Исследованы процессы реформирования образования. На Закарпатье советская власть долгое время не могла ничего сделать с воспитанием неславянских народов. Для неславянских представителей общества, как свидетельствуют источники, было трудно адаптироваться к новой политической системе и к новой какдля Закарпатья коммунистической идеологии.

Ключевые слова: Закарпатье, культура, пресса, образование, идеология.

Kish Ye., Maroshan k. Functioning peculiarities of cultural institutions in Zakarpattia during 1950-1953 based on newspaper articles

The following article deals with the situation of Transcarpathian cultural institutions during the Soviet period between 1950 and 1953. In this article I mention and characterize the introduction of the libraries of the time, the works of the most popular topics, including the newspapers, cinema and museum visits. Based on the years studied, there has been a recovery in educational institutions and cultural life. Great attention was paid to the training of teachers as they played a major role in communist education of youth. Their main task was to propagate the glorious past of the Soviet Union and to increase the pupils' love for their home. There were many disabilities in the district schools. After 1946, the number of pupils and schools grew in vain, the quality of teaching did not improve for a long time. The reason for this was that the schools did not have enough equipment and books. Many textbooks were useless because most of them were translated from Russian, making it difficult for students to interpret mirror translation.

Due to the lack of Hungarian textbooks, children were often taught to read books from Hungarian journals. Hungarian textbooks came to Hungary for the first time in Transcarpathia only in the 1980s. Teachers' work was also hampered by the lack of a unified curriculum. Only in 1951 was the single curriculum introduced. The first book in Hungarian, published in the Soviet system, was the Nikitin's Book of Scriptures and Sackakov's book The History of the Soviet Union. Libraries have been established in more and more villages and villages, which have been a great success for the population. Museums and theaters have been created for the entertainment of citizens. The cinema was released in major cities where the most famous and latest Soviet films were presented to the audience. They also had an impact on people's mentality.

Key words: Soviet Union, Transcarpathia, culture, media, education, ideology. 
DOI: 10.33310/2519-2809-2019-47-1-108-114

УДК 47 (477)

\author{
ГЕННАДИЙ КОВАЛЬ \\ вчитель історії та географиї \\ Новосафронівська загальноосвітня школа I-III ступенів. \\ Село Новосафронівка Новоодеський район Миколаївська область, Україна \\ e-mail: genkoval0805@gmail.com
}

\title{
ПЛАНИРОВАНИЕ СТРОИТЕЛЬСТВА НИКОЛАЕВСКОЙ ГОРОДСКОЙ УПРАВОЙ КАНАЛИЗАЦИИ В 1909 И 1912 ГОДАХ
}

\begin{abstract}
В статье рассказано о планировании николаевской городской управой канализации в городе Николаеве в 1909 и 1912 годах. Планирование сети канализации представлено в докладе председателя водопроводной комиссии Х. М. Матвеева. Детально расписан процесс сооружения канализации, домовых ответвлений, стоимость проекта для николаевских домовладельцев, займы городу для строительства канализации. Представлены способы очистки сточных вод, вывозки нечистот, недовольство жителей района Слободки г. Николаева по поводу отказа от проведения у них канализации. Показана степень готовности к сооружению канализации в середине 1912 года, инженерные проекты, ходатайства об отчуждении в пользу города 25 десятин земли у морского ведомства для устройства биологических фильтров.

Ключевые слова: канализация, городская управа, доклад, планирование, ответвления, расход воды, способы очистки.
\end{abstract}

Развитие городов в начале XX ст., увеличение численности их населения привело к решению разных коммунальных вопросов, в том числе сооружения канализаций. Не стал исключением и город Николаев. По этой теме нет отдельных исследований историков и краеведов. К данной проблеме, в широком смысле благоустройства Николаева, обращался ранее автор данной статьи [1, с. 35-40]. В этой публикации, на основании материалов периодики, поставлено целью показать планирование сооружения канализации в городе Николаеве в 1909 и 1912 годах.

Николаевское городское общественное управление еще в 1900 году наметило устройство в городе Николаеве канализации. Из средств полукопеечного сбора городского бюджета получено разрешенное на устройство канализации с коллектором для отвода дождевых вод - 1.440.000 рублей [2, арк. 1-2].

Водопровод с самого начала своего существования предполагался как доходная статья городского бюджета; с другой стороны необходимость наличия водопровода была очевидна и до его сооружения. Канализация-же в этом отношении занимает совершенно особое положение; во-первых, она является исключи- тельно расходной статьей и притом довольно обременительной для города с небольшим бюджетом; во-вторых, самая необходимость канализации становится очевидной и неоспоримой только после того, как водопровод получает достаточно широкое развитие.

Николаевская водопроводная исполнительная комиссия еще в 1908 году выдвинула вопрос о постройке канализации. Для разработки этого вопроса Городской управой было созвано соединенное заседание комиссии водопроводной и по благоустройству города. На этом заседании поднят вопрос о целесообразности объявления в специальных кругах конкурса на наиболее подходящую для нашего города систему канализации, но против такого предложения высказался председатель водопроводной комиссии Х. М. Матвеев. По его мнению, все существующие системы канализации достаточно уже известны и все дело сводится к выбору наиболее подходящей к местным условиям, - а для этого совсем нет необходимости тратиться на конкурс. Обе комиссии согласились с мнением Матвеева и просили его взять на себя труд по составлению доклада в думу по этому вопросу [3]. 
Председателем водопроводной комиссии Х. М. Матвеевым представлен обширный доклад о сооружении в Николаеве канализации, составленный по поручению соединенного заседания комиссии водопроводной и по благоустройству города. В докладе отмечалось, что важнейшей обязанностью городского общественного самоуправления, несомненно, должна быть забота об улучшении санитарного состояния города, так как от этого непосредственно зависит размер заболеваемости и смертности среди населения. Для достижения же санитарного благополучия города лучшее и едва-ли не единственное средство это устройство рациональной канализации, посредством которой все отбросы и органические выделения с возможно большей скоростью удаляются за черту города. Проинформировано о деле строительства канализации в муниципалитетах многих городов Западной Европы. Вопрос об удалении нечистот обостряется с каждым годом, и в недалеком будущем настоятельно потребует своего коренного решения. До проведения канализации, удаление нечистот производится непосредственно в поглощающие ямы и по мере накопления их вывозят на места свалок. Этот способ, безусловно осуждаемый санитарией, имеет два существенных недостатка: 1) он загрязняет и заражает почву около жилищ; 2) поглощательная способность ям прогрессивно падает, и по истечении более или менее значительного времени ямы потребуют более частого опоражнивания посредством дорогостоящей и неудобной вывозки нечистот на места свалок. У нас еще далеко не всеми признается, что поглощающие ямы заражают почву и служат причиной неисчислимых бедствий. Города, имеющие водопровод 8-10 лет, уже совсем не сохранили сколько-нибудь оправдывающих свое название поглощающих ям, - все они превратились в простые выгребные. Какую же огромную сумму составляют расходы отдельных домохозяев по вывозке нечистот на места свалки при быстро прогрессирующем потреблении воды? В виде ответа на этот вопрос Матвеев привел пример одной городской усадьбы. Население усадьбы 28-30 человек. Расход воды за год (с октября 1906 по октябрь 1907 г.) -
31.100 ведер, то есть 2,9 ведра в день на человека. Стоимость этой воды - 93 руб. 30 коп. Вывозка-же нечистот из ям составила расход в 180 руб., то есть за год обошлась вдвое дороже самой воды. Затем по 20 июня 1908 года за вывоз уплачено 145 руб. к концу отчетного года ямы переполнились и потребовали расхода в 58 руб.: кроме того израсходовано на очистку дворовых клозетов 6 руб., - таким образом за второй год по усадьбе расходы по вывозке составили 209 руб.; воды-же за второй год потреблено около 35.000 ведер, то есть на 105 руб.

Следовательно, вывозка опять стоила вдвое дороже чистой воды. Другими словами, каждые 100 ведер воды обходились домовладельцу не в 30 коп., как гласит официальная такса, а в 90 коп. В заключении, Х. Матвеев пришел к следующим выводам: 1). Количество вывозимых клоачных вод из поглощающих ям ежегодно возрастает, если даже количество потребляемой воды остается постоянным. 2) Поглощающие ямы естественным порядком превращаются в выгребные. 3) Расход по вывозу нечистот уже теперь для многих усадеб в несколько раз превышает стоимость водоснабжения и ежегодно возрастает. 4) В недалеком будущем мы будем иметь непосильные расходы по ассенизации усадеб [4]. Потребление воды из водопровода, самая дорогая часть которого (сеть) построена на 1.000.000 ведер воды в сутки, не может нормально возрастать вследствие дороговизны отвозки отработанных вод, а от ограниченного потребления воды и загрязнения почвы создаются антигигиенические, антисанитарные условия жизни населения, вызывающие большой процент заболеваемости и смертности. Все эти выводы сами собою выдвигают вопрос об устройстве рациональной ассенизации города и не путем предполагаемого городского ассенизационного обоза, а единственно устройством правильной канализации города.

Канализация имеет целью все отработанные воды, отбросы и выделения органической жизни возможно скорее (до их распада) удалить за черту городской территории. По объему функций канализация разделяется на две главные категории или системы: 
1) Общесплавная система, при которой все направляется в подземные каналы, не исключая и дождевых вод, выпадающих на улицы и усадебные дворы.

2) Раздельно-сплавная система, при которой в каналы попадают жидкие и полужидкие нечистоты, то есть все тоже, что и при общесплавной системе, за исключением только дождевых вод.

Нуждам и средствам в Николаеве из этих двух систем канализации соответствует раздельно-сплавная. В доказательство этого положения Х. М. Матвеев привел данные, что сооружение каналов раздельно-сплавной системе в 2-3 раза дешевле, чем при общесплавной. Достаточно сказать, что раздельная система канализации устроена в Москве и в Киеве и, что такие города, как Харьков, Екатеринослав, Полтава, Самара и другие, приступают к сооружению у себя канализации также по раздельно-сплавной системе [5].

Указав в общих чертах на преимущества для Николаева раздельно-сплавной системы канализации, X. М. Матвеев представил ее общую схему: по улицам, следуя их естественному уклону, прокладываются гончарные трубы, соединения которых заделываются асфальтом. Эти трубы (диаметром не менее 8 дюймов) укладываются на такой глубине, чтобы дворовые присоединения к ним, несущие воды от клозетов, раковин, помойных ям, имели достаточный уклон для спуска жидких и полужидких нечистот. Указанные 8-дюймовые трубы, соединяясь вместе, образуют магистральные каналы, или даже коллектора, которые идут к главному коллектору, направляющему все клоачные воды на станцию. Для надзора за правильным функционированием канализации вся сеть каналов снабжается смотровыми колодцами на расстояние один от другого от 20 до 30 саж. В топографическом отношении территория Николаева на столько удобна, что сеть канализации не требует других приспособлений. При средней глубине заложения каналов около 2 саж. воды со всех усадеб нашего города могут быть самотеком направлены в главный коллектор, который выводит их к берегу реки Буг у Поповой Балки. Это обстоятельст- во весьма важно, так как значительно упрощает и удешевляет как самое устройство канализации, так и ее эксплуатации. Станция для перекачки канализационной воды потребовалось бы только одна у конца главного коллектора, - и то лишь в том случае, если бы для очистки вод применены были поля орошения; при биологической же системы очистки процесс передачи на станцию происходил бы естественным течением воды.

Затем Х. М. Матвеев перешел к разрешению не менее важного для Николаева вопроса: какой способ очистки клоачных вод применим для нашего города? Возможность спуска канализационных вод без предварительной очистки прямо в реку у нас совершенно исключается, так как при отсутствии сколько-нибудь значительного течения в наших обеих реках это и невозможно, и не получило бы разрешения высших властей. Химический способ очистки очень сложен, дорог и уже почти нигде не принимается. Остается еще два способа очистки: поля орошения или некоторых их видоизменение - поля - фильтры и биологический способ. Наилучшим способом очистки сточных вод бесспорно считаются поля орошения и поля-фильтры, - иначе способ перемежающейся фильтрации. Главнейший-же недостаток полей орошения и полей-фильтров - их дороговизна. Стоимость полей орошения с необходимыми приспособлениями в Николаеве около 650.000 руб. Что касается полей - фильтров, то они совершенно неприменимы для Николаева уже по одному тому, что в окружающих наш город землях нет подходящей для них почвы [6].

Биологический способ очистки канализационных вод представляет собою, концентрированный процесс минерализации полей орошения или перемежающейся фильтрации. В устройстве биологического способа существует две вариации: способом периодического действия фильтров, - так называемый контактный способ и способ непрерывного действия.

При надлежащих размерах фильтров биологический способ очистки дает вполне удовлетворительные результаты. Приблизительная стоимость биологической станции 
по периодическому способу определяется от 25 до 50 коп. на 1 ведро в зависимости загрузочного материала фильтров (кокс, щебень или шлаки). Для Николаева в первые годы действия канализации достаточна станция на 250.000 ведер в сутки при условии, что она могла бы быть расширена впоследствии до 500.000 ведер. Такая станция, принимая среднюю стоимость на годовое ведро 50 коп., обойдется около 185.000 руб., а для очистки 500.000 ведер в сутки - около 250.000 руб.; а также считая земли, нужной для станции в размере около $1 \frac{1}{2} 2$ десятины. Как по результатам действия, так и по стоимости биологический способ является наиболее выгодным и подходящим для Николаева. Этот же способ проектируется для новой канализации Харькова и для Киева взамен расширения существующих там уже полей орошения[7].

Устройство канализации X. Матвеев предложил разделить на две очереди: в первую очередь канализировать Одесскую и Московскую части города, где по всем улицам уложена водопроводная сеть, а также канализировать те улицы 1-й и 2-й Адмиралтейских частей, по которым проложены магистрали и которые идут к городской больнице, морскому госпиталю, казармам и коммерческому порту, - куда будет направлен главный коллектор. Общее протяжение этих улиц составляет 27.000 сажень. Во вторую очередь канализации входит остальная часть города. С будущим приростом население Одесской и Московской частей принимается в 100.000 человек при потреблении воды по 5 ведер в день на человека. Следовательно, канализация первой очереди должна иметь пропускную способность на 500.000 ведер в сутки. По раздельно-сплавной системе все коллектора устраиваются из гончарных труб диаметром не больше 26 дюймов. По расчету Х. М. Матвеева, укладка труб с выкопкою рвов, заделкою стыков асфальтом и двукратным замощением канав обойдется в 420.000 руб. Смотровых колодцев на расстоянии друг от друга в 30 саженей потребуется около 900 штук; с бетонными работами и чугунными крышками они обойдутся не дороже 50 рублей за штуку, или всего 45000 рублей. Биологическая станция для канализации первой очере- ди на ближайшие несколько лет, по мнению Матвеева, обойдется в 125.000 руб. Сточный коллектор на берегу реки Буг Поповой Балки вместе с водопроводом обойдется в 25.000 руб. Жилые дома и бактериологическая лаборатория на станции обойдутся приблизительно в 30.000 руб. На изыскания, проекты, технический надзор и непредвиденные расходы Х. Матвеев запланировал еще 85.000 руб. Всего стоимость канализации первой очереди с очисткою 250.000 ведер в сутки выразится суммою 785.000 руб., а с расширением станции через 3-4 года (125.000 руб.) 910.000 руб. Однако вся стоимость канализации по строительным расходам: устройство и оборудование электрическими насосами водопроводных колодцев 40.000 рублей, выплата процентов и погашение строительного капитала за время создания канализации 150.000 рублей. Таким образом полная стоимость канализации выразится суммою 1.100 .000 рублей.

Если этот капитал городское общественное управление пожелает получить путем облигационного займа, то минимальный облигационный капитал должен быть не менее 1.466.000 рублей, а ежегодные взносы по займу составят 87.600 рублей.

Стоимость раздельно-сплавной канализации при длине каналов в 54 версты для обслуживания населения в 100.000 человек, Х. Матвеев считал реально умеренною. Такая сравнительная дешевизна объясняется необыкновенно выгодными топографическими условиями территории Николаева, благодаря которым не потребуется ни одной станции, ни одного аппарата для перекачки канализационных вод, - все они могут поступать на очистную станцию исключительно самотеком. Это обстоятельство имеет еще более важное значение на уменьшение расходов по эксплуатации канализации.

Материальный успех канализации зависит от числа присоединившихся к канализации усадеб. Как известно, при сооружении водопровода домовые ответвления на 1 сажень во двор делались за счет города. При сооружении канализации также следует применить этот блестяще оправдавшийся прием, и если не делать домовых ответвлений 
совсем за счет города, то тогда хотя бы открыть желающим домовладельцам дешевый и долгосрочный кредит. Канализация усадеб стоит значительно дороже проводки водопровода, а потому в этом случае еще более нужна помощь домовладельцам со стороны города. По данным инженера Штольцмана в Киеве средняя стоимость домовой канализации выразилась суммою 610 рублей. В Николаеве, где дома по преимуществу одноэтажные, расходы эти будут значительно меньше, но вероятно все-же в среднем обойдутся около 300-400 рублей на усадьбу. Городскому общественному управлению следовало бы в интересах успеха канализации открыть беспроцентный кредит с рассрочкой погашения в течении 3 лет тем лицам, которые пожелают присоединиться к канализации в первый же год ее действия [8].

Эксплуатация канализации тесно связана с эксплуатацией водопровода, так как сопровождается быстрым ростом расхода воды; в то время как в неканализованных городах расход воды редко достигает $1 \frac{1 / 2}{2}$ ведра на человека в сутки, в канализованных городах он достигает 8 и больше ведер. Суточный расход воды в Одессе составляет 6,3 ведра на жителя, в Киеве 5 ведер. В Николаеве за прошлый год средний суточный расход воды был 110.000 ведер, то есть 1,1 ведра на человека; в 1909 году можно ожидать 1,3 ведра. Обыкновенно канализация учетверяет суточный расход воды. Из предосторожности Х. Матвеев предположил, что в Николаеве при канализации расход только удвоится и даст за год 100.000.000 ведер, или 2,7 ведра в сутки на человека. Затем он полагает, что и такса на воду с 30 коп. понизится до 25 коп. за 100 ведер.

За пользование канализацией обыкновенно уплачивается пропорционально потреблению воды: в Варшаве, например, установлен сбор в размере $4 \%$ стоимости израсходованной воды. Для Николаева Матвеев рекомендовал систему, - 15 коп. за 100 ведер потребленной воды, - иными словами, за эти 100 ведер домовладелец будет уплачивать по 40 коп. Еще в начале доклада мы видели, что даже по скромному расчету каждые 100 ведер потребленной воды вместе с выводкой обходятся домовладельцу не дешевле 90 коп. Затем автор доклада дает такой приблизительный подсчет: в канализации первые годы ее действия присоединится только половина дворов водопроводной сети; эти усадьбы будут потреблять вдвое больше воды, чем не канализованные, то есть из 100 миллионов ведер 66 миллионов, придется на долю первых: за 100 миллионов ведер поступит в кассу (по 25 копеек за 100 ведер) или 250.000 руб., а дополнительный канализационный сбор (15 коп. за 100 ведер) за 66 миллионов ведер даст 99.000 руб. - всего 349.000 р. Расходы по эксплуатации водопровода и канализации: проценты и погашение по первому 57.000 р., а по второй 87.600 , содержание водопровода 80.000 р., содержание канализации 26.400 р., 251.000 р. При таком расчете город будет иметь от эксплуатации обоих предприятий около 98.000 р. чистого дохода. Далее докладчик, постарался определить на сколько выгодно и домовладельцам не медлить с присоединением к канализации, когда она будет устроена, даже при установлении дополнительной платы по 15 коп. за 100 ведер потребленной воды. При устройстве канализации домовладельцы будут избавлены от лишних расходов, которые для всех суммируются в огромный ежегодно теряемый капитал. К тому же они будут освобождены от заражающих воздух операций по вычерпыванию и вывозке нечистот.

Таким образом, не только санитарный, но и коммерческий расчет сделает канализацию популярной в Николаеве. Блага канализации познаются и оцениваются населением очень быстро, и привлечение отдельных усадеб к присоединению к каналам не нуждается ни в каких принудительных мерах, как раньше об этом думали [9].

На заседаниях водопроводной комиссии и комиссии о пользах и нуждах города одобрили этот проект и постановили отпечатать его и разослать гласным думы [10].

10 мая 1909 года представитель берлинской фирмы инженер И. Корин предложил городской управе свои услуги по устройству канализации и биологической станции для очистки сточных вод в городе [11]. Николаевским городским управлением в середине 1912 года 
начаты подготовительные работы по сооружению канализации. 16 августа 1912 года под председательством члена управы Х. Матвеева состоялось заседание канализационной комиссии [12]. 23 сентября 1912 года председатель канализационного комитета Х. Матвеев объявил, что проект инженера Черкеза по сооружению канализации будет представлен городскому управлению к 1 октябрю 1912 года. В первую очередь канализация будет проведена в районе от Спасска и до Садовой улицы. Что же касается остальной части города, то есть рабочей Слободки, то там канализация будет проведена во вторую очередь за счет 2-го займа [13]. Вскоре местная пресса опубликовала статьюфельетон «Пасынки города», в которой отмечалось, что все культурные блага городской управы не для окраин [14].
В конце сентября 1912 года градоначальник Николаева запросил городскую управу о присылке планов предстоящей канализации, необходимых для детального рассмотрения ходатайства городского управления об отчуждении в пользу города 25 десятин земли морского ведомства для устройства на них биологических фильтров [15]. Таким образом, мы видим насколько насыщенной, сложной и разноплановой была работа по планированию городской управой канализации в Николаеве в 1909 и 1912 годах. Это планирование полностью отображено в представленном докладе председателя водопроводной комиссии Х. М. Матвеева, в котором указаны статистические данные, цифры расходов, проекты сооружения канализации.

\section{Списокиспользованных источников}

1. Коваль Г.П. Діяльність Миколаївської міської думи в галузі благоустрою міста Миколаєва в XIX - на початку XX століття. Краєзнавчий альманах. Історія. Археологія. Наука. Культура. Освіта. Промисловість. Сільське господарство. № Миколаїв: ОІППО, 2007. С. 35-40.

2. Державний архів Миколаївської області (ДАМО) Ф. 216. Оп. 4. Спр. 7. Арк. 1-2.

3. Николаевский курьер. 1909. 24 апреля.

4. Там же. 29 апреля.

5. Там же. 2 мая.

6. Там же. 7 мая.

7. Там же. 13 мая.

8. Там же. 15 мая.

9. Там же. 21 мая.

10. Там же. 8 июля.

11. Там же. 12 мая.

12. Трудовая газета. 1912. 19 августа.

13. Там же. 25 сентября.

14. Там же. 26 сентября.

15. Там же. 28 сентября

\section{References}

1. Koval G.P. Diyalnist Mykolaivskoyi miskoyi dumy v galuzi blagoustroyu mista Mykolayeva v XIX - na pochatku XX stolittya. Krayeznavchyy almanakh/Istoriya. Arkheologiya. Nauka. Kultura. Osvita. Promislovist. Silske gospodarstvo. № 1 . Mykolaiv: OIPPO, 2007. S. 35-40.

Коваль Г. Планування будівництва Миколаӥвською міською управою каналізації у 1909 та 1912 роках

У статті висвітлено планування міською управою каналізації в місті Миколаєві в 1901 та 1912 роках. Планування мережі каналізації представлено в доповіді голови водопровідної комісії Х. Матвєєва. Детально розписано процес споруди каналізації, будинкових відгалужень, вартість проекту для миколаївських домовласників, позики місту для будівництва каналізації. Подано способи очищення стічних вод, вивезення нечистот, незадоволення жителів району Слобідки Миколаєва з приводу відмови від проведення у них каналізації. Показана ступінь готовності до спорудження каналізації в середині 1912 року, інженерні проекти, клопотання про відчуження на користь міста 25 десятин землі у морського відомства для спорудження біологічних фільтрів.

Ключові слова: каналізація, міська управа, доповідь, планування, відгалуження, витрати води, способи очищення. 


\section{2}

Koval G. Nikolaev city sewage system administration, planning and consruction in 1909 and

The article talks about Mykolayiv city administration water supply planning in 1909 and 1912. Sewerage system planning is presented by H.M.Matveev, who is chairman of the water supply commitee. It was given detailed description of the sewage construction process, house branches, cost of Nikolaev homeowners' project, electric motors, fleshtankas, cesspools, irrigation fields installation, and the amount of consumed water. The amount of the sewage construction city loan, homeowners' loans, sewage water consumption calculations, and other data are given. Kh.M. Matveev presented examples of the device, sewage systems with the cities of the Russian Empire comparisons. On the first place, it is planned to spend money on the loan to carry out sewage in the Odessa and Moscow parts and some streets of the Admiral part, provided methods of wastewater treatment, sewage removing. It is emphasized Slobodka residents dissatisfaction because of refusing to carry out their sewerage. Technical characteristics of sewage methods, cesspools, possibility of Southern Bug River contamination, and H.M. Matveev conclusions about sewage system construction are provided. It is noted that construction and operation of such an important enterprise as a sewage system should be in the hands of the city's public self-government, but in no case concessionaires. It is planned that the sewage system should be constructed in an economic way, or, more correctly, with the help of separate contracts for separate special works. It is specified that in the near future, Mykolaiv city public administration will have unreasonable costs for manor houses assassinating. It was shown readiness for the sewerage construction in the middle of 1912, Cherkes and Kassimovsky leveling works and projects, a petition for the 25 acres of land deposition from the maritime department for the biological filters construction.

Key words: sewage, impuring, city sewage administration, report, projects, planning, water buckets, branches, water consumption, flushtank, cesspits, cleaning methods. 


\section{ВІДОМОСТІ ПРО АВТОРІВ}

БоГУНЕНКО Валерій Олександрович, викладач кафедри вітчизняної та зарубіжної історії Горлівського інституту іноземних мов м. Бахмут, Україна.

БУГЛАЙ Наталя Михайлівна, доктор історичних наук, професор кафедри історії Миколаївського національного університету імені В. О. Сухомлинського.

доЛИНАЙ Жужанна Федорівна, старший викладач кафедри історії Угорщини та європейської інтеграції, Українськоугорський навчально-науковий інститут, Ужгородський національний університет.

доРГАЙ Жофіа Бейловна, магістр історії кафедри історії Угорщини та європейської інтеграції,Українсько-угорський навчальнонауковий інститут, Ужгородський національний університет.

ЗЕРКАЛЬ Микола Миколайович, доктор історичних наук, професор кафедри історії Миколаївського національного університету імені В. О. Сухомлинського.

ЗУБАНИЧ Ласлов Ласлович, кандидат історічних наук, доцент кафедри історії Угорщини та європейської інтеграції, Ужгородський національний університет.

ЙоВЖА Оттила, аспірант Національного університету державної служби, м. Будапешт, Угорщина.

КІШ Єва Бернатівна, доктор історичних наук, завідувач кафедри історії Угорщини та європейської інтеграції Українськоугорського навчально-наукового інституту Ужгородського національного університету, член зовнішньої колегії Академії Наук Угорщини.

КОВАЛЬ Геннадій Павлович, вчитель історії та географії Новосафронівської ЗОШ Новоодеського району Миколаївської області.
КОВАЧ Елеонора Гейзівна, старший викладач кафедри історії Угорщини та європейської інтеграції, Українсько-угорський навчально-науковий інститут, Ужгородський національний університет.

КУЗОВКОВ Володимир Володимирович, кандидат історичних наук, доцент кафедри історії та археології Миколаївського національного університету імені В. О. Сухомлинського.

КУЧЕР Віталій Вікторович, аспірант кафедри історії та археології Миколаївського національного університету імені В. О. Сухомлинського.

ЛАСІнСЬКА Маріанна Юріївна, кандидат історичних наук, доцент кафедри історії Миколаївського національного університету імені В. О. Сухомлинського.

МАРОШАН Камілла Федорівна, магістр історії кафедри історії Угорщини та європейської інтеграції, Українсько-угорський навчально-науковий інститут, Ужгородський національний університет.

ПАРХОМЕНКО Владислав Анатолійович, доктор історичних наук, професор кафедри історії Миколаївського національного університету імені В. О. Сухомлинського.

РЕВЕНКО Віра Валентинівна, кандидат історичних наук, старший викладач кафедри історії України Миколаївського національного університету імені В. О. Сухомлинського.

ШКАБУРА Ярослав Іванович, заступник директора Центра болгаристики та балканських досліджень імені Марина Дринова, Харківський національний університет імені В. Н. Каразіна 


\section{НАУКОВИЙ ВІСНИК МИКОЛАЇВСЬКОГО НАЦІОНАЛЬНОГО УНІВЕРСИТЕТУ імені В. О. СУХОМЛИНСЬКОГО}

\section{ІСТОРИЧНІ НАУКИ}

№ 2 (46), грудень 2018

Відповідальність за цитування та зміст статей несуть автори.

Формат 60×84 1/8. Ум. друк. арк. 13,5.

Тираж 100 пр.

Свідоцтво про реєстрацію друкованого засобу масової інформації серія КВ № 20999-1010799 Р від 25.09.2014 р.

Адреса редакції та видавця:

Видавництво МНУ імені В. О. Сухомлинського

54030, м. Миколаїв, вул. Нікольська, 24

тел. (0512) 37-88-38, т/ф 37-88-15

e-mail: visnyk.editor@mdu.edu.ua

Свідоцтво про внесення до Державного реєстру суб'єктів видавничої справи ДК № 3375 від 27.01.2009 р. 